\title{
Interpersoonlijke vaardigheidstherapieën voor kansarmen
}

Citation for published version (APA):

Beekers, R. J. M. (1982). Interpersoonlijke vaardigheidstherapieën voor kansarmen. [Doctoral Thesis, Maastricht University]. Swets \& Zeitlinger. https://doi.org/10.26481/dis.19821015rb

Document status and date:

Published: 01/01/1982

DOI:

10.26481/dis.19821015rb

Document Version:

Publisher's PDF, also known as Version of record

\section{Please check the document version of this publication:}

- A submitted manuscript is the version of the article upon submission and before peer-review. There can be important differences between the submitted version and the official published version of record.

People interested in the research are advised to contact the author for the final version of the publication, or visit the DOI to the publisher's website.

- The final author version and the galley proof are versions of the publication after peer review.

- The final published version features the final layout of the paper including the volume, issue and page numbers.

Link to publication

\footnotetext{
General rights rights.

- You may freely distribute the URL identifying the publication in the public portal. please follow below link for the End User Agreement:

www.umlib.nl/taverne-license

Take down policy

If you believe that this document breaches copyright please contact us at:

repository@maastrichtuniversity.nl

providing details and we will investigate your claim.
}

Copyright and moral rights for the publications made accessible in the public portal are retained by the authors and/or other copyright owners and it is a condition of accessing publications that users recognise and abide by the legal requirements associated with these

- Users may download and print one copy of any publication from the public portal for the purpose of private study or research.

- You may not further distribute the material or use it for any profit-making activity or commercial gain

If the publication is distributed under the terms of Article $25 \mathrm{fa}$ of the Dutch Copyright Act, indicated by the "Taverne" license above, 
INTERPERSOONLIJKE

VAARDIGHEIDSTHERAPIEËN

VOOR KANSARMEN 



\section{INTERPERSOONLIJKE VAARDIGHEIDSTHERAPIEËN VOOR KANSARMEN}

\section{PROEFSCHRIFT}

ter verkrijging van de graad van doctor in de geneeskunde

aan de Rijksuniversiteit Limburg te Mastricht op gezag van de Rector Magnificus prof. dr. H. C. Hemker, volgens besluit van het College van Dekanen

in het openbaar te verdedigen in de Aula van de Universiteit op vrijdag 15 oktober 1982 , des namiddags te 16.00 uur

door

\section{REMACLUS JEAN MARIA BEEKERS \\ geboren te Nistelrode}


Promotor : Prof. dr. J. J. C. B. Bremer

Referenten: Prof. dr. R. W. Ramsay

Prof. dr. M. M. W. Richartz

Omslag ontwerp H. Veltman

Gedrukt bij Offsetdrukkerij Kanters B.V., Alblasserdam
Copyright 1982 R. J. M. Beekers en Swets en Zeitlinger

Alle rechten voorbehouden. Niets uit deze uitgave mag worden verveelwoudigd, opgeslagen in een geautomatiseerd gegevensbestand, of openbaar gemaakt, in enige vorm of op enige wijze, hetzij elektronisch, mechanisch, door fotokopieën, opnamen, of op enige andere manier, zonder voorafgaande schriftelijke toestemming van de uitgever.

All rights reserved. No part of this publication may be reproduced stored in a retrieval system, or transmitued, in any form or by any means, electronic, mechanical, photocopying, recording, or otherwise, without the prior written permission of the publisher. 
Aan Annelie 
Manuscript

: Hannie Spronck

Afbeelaing omslag : Guus van Rooy 
Aan het werk dat aan dit proefschrift ten grondslag ligt is door velen met grote inzet bijgedragen.

Met respect en dankbaarheid noem ik allereerst Bea Beckers en Jan van Houtem die een groot aandeel hebben gehad in de opzet en uitvoering van de diverse onderzoekingen, en Jos Bongaarts en Jan Gooljen voor hun trouwe bijaragen tot de ontwikkeling van de therapie-programina's en de verspreiding van de methode in de regio.

De samenwerking met de Toneelacademie Maastricht heaft gelejd tot de productie van een serie video-programma's, die cen grote rol spelen in onze vaardigheidstherapieën voor kansarmen. Veel creativitelt en doorzettingswermogen kenmerkten zowel de mensien die deze samenwerking mogelijk maakten -wijlen Nico de Vrede, Jacques Giesen en Leo Maessenals degenen die jarenlang bij het studio-werk betrokken warem: Doc Janssen, Pieter Hoes, Clement Mantz, Hans Holthaus, Enrico Baccalà, Sjef Troisfontaine en de successievelijk aan onze "videoploeg" verbonden stagiairs Anke Brouwer, Wouter Daane, Agnes Harleman, Claran Wielenga, John Ramaekers, Marcel Jansen met medewerking van diwerse vrijwilligers. en studenten.

De therapeuten die zich door ons lieten oplleiden (teveel on hiex bij nam te noemer) dank ik voor het in ons gestelde vertrouwen, voor het enthousiasme en de opmerkelijke protocol-trouw die zij in hun toepassingen van de intexpersoonlijke vaardigheldstherapleên aan de dag leggen en voox hun medewerking aan het onderzoek. 
Jos Peters en Fits van Ham ber $1 k$ exkentelijk voor hun aandeel in het opatarten van het project; Dorine Henquet, Ruvd Halfens, Ad van Straten, Paul Geurten, Ron Zwaan, Jan Theunissen, Jan OLthof, Ton Schmidt, Theo Riefe, Jan van Dalen, Jef wijnen, woody Laurens, Arive Mleke Brands en Martha Moonen voor hun witeenlopende bijdragen dan delen van het onderzoeksprogramma, Mart Claessens en Leo vanmolkot voor hun bljdxagen aan de versprelding van de methode in de geestelijke gezondheidszorg in Limburg, Maarten Lange en Ad Appels voor hun wardewolle adviezen, Hannie Spronok voor haar voortreffelijke administratieve ondersteuning, de medewerkexs van de universitaire diensten wor hum diverse bijaragen en naturulijk Joost Bremer, mijn. promotor, voor aign vertrouwen en voortdurende andacht.

Beste vrienden, jullie hebben een stuk van je leven in 'het Goldsteinproject' gestopt. Samen hebben we enorme bergen werk verzet, in een sfeer wan vastberadenheid en samhorigheid. Het was vaak een heksenKetel, doch tevens de gelukkigste periode in mijn leven. Ik dank jullie voor het vertrouwen dat jullie me schonken en hoop dat we het werk dat ong nog te doen staat op even prettige en productieve wijze zullen kunneru voltooien. 
INHOUDSOPGAVE

Bladzijäe

1. Inleiding

1.1 Kansarmen in de psychotherapie 2

1.2 Pogingen tot overbrugging van de kloof 5

1.3 De methode van Goldstein 8

1.3.1 Modeling 9

1.3.2 Gedragsoefening 9

1.3 .3 Bekrachtiging 10

1.3.4 Transfer-training 11

1.3 .5 De vaardigheden 12

1.3.6 Geluidsbanden als therapeutisch hulpmiddel 13

1.4 Goldsteinthexapieän voor Limburgse kansarmen 14

1.4.1 RIAGG-bereikbaarheld 15

1.4.2 Het Goldsteinproject 18

2. Theoretische ontwikkelingen en hun consequenties voor vaardigheidstherapleän 20

2.1 Ontoereikende verklaringsmodellen 21

2.2 Het cognitief social-leertheoretisch model 22

2.3 Bandura" s self-efficacy theorie 24

2.4 Consequenties voor Golastein"s STT 26

3. De keuze van interpersioon Lljke vaardigheden 30

3.1 op zoek naax een referentlekader 31

3.1.1 Hoofddimensies van interpersoonlijk gedrag 32

3.1.2 Leary's roos en de ICL 34 
3.2 rCL-afname bif clifenten 36

3.2 .1 onderzoeksopzet 37

3.2 .2 Respondenten 38

3.3 Controle van de ICL 39

3.3.1 Interne consistenties 39

3.3.2 Relaties tussen de variabelen 39

3.3.3 Factor-analyse 40

3.4 Interpersoonlijk gedrag van Libo-cliënten 42

3.4.1 Libo's versus niet-Libo"s: 42

3.4.2 Gedragstekorten 43

3.4 .3 Gedragsexcessen 44

3.5 Interpersoon 1 jke wardigheden voor kansarmen 47

3.5 .1 De vaardigheden 47

3.5 .2 De leerpunten 48

3.6 Samenvatting 51

4. De ontwikkeling van modelbanden 52

4.1 Modeling: Theoretische aspecten 52

4.1.1 Mogelijke modeling-effecten 53

4.1.2 Determinerende processen 54

4.2 Model-banden voor intexpersoonlijke vaardigheldsthexapleênn $\quad 55$

4.2.1 Van audio- maar video-modeling 56

$\begin{array}{lll}4.2 .2 \text { Van enkelvoudige voorbeelden naar contrastparen } \quad 57 & 7\end{array}$

4.2.3 Naar contrastparen met énzelfde hoofdrolspelex 58

5. Het theraple-programma 61

5.1 Progranma-beschrijwing 62

5.1 .1 De introductie 63

5.1 .2 Het imiterend rollenspel 64

5.1 .3 Het anticiperend rollenspel 66

5.1.4 Het reconstruerend rollenspe1 70

$\begin{array}{ll}5.1 .5 \text { De huiswerkbesprekingen } & 72\end{array}$

5.1.6 Programina-overzicht 74 
5.2 Aanvillende richtlijnen en toelichtingen

5.2.1 Twee therapeuten

5.2 .2 Directiviteit en tempo 75

5.2 .3 Het speelvlak 76

5.2.4 Negatieve zelfbeweringen van cliënten 76

5.2 .5 Moeilijke clienten 77

5.2.6 Kiezen van modelien 78

5.2.7 Bekrachtigers en bekrachtigende instanties 79

5.2.8 Bekrachtiging en weerstand tegen uitdoving 79

5.2.9 Beëindiging wan het rollenspel 81

5.2.10 Bedekte gedragingen 81

5.2.11 Overige groepstechnieken 8.2

5.3 Het programma als ultvoeringsvorm van Goldstein"s SLT 82

5.3.1 Modeling 83

5.3.2 Gedragsoefening 83

5.3.3 Bekrachtiging 84

5.3.4 Transfer-training 84

5.4 Het programma in cognitief sociaal-leertheoretisch perspectief 86

5.4.1 Nadruk op competentie-verwachtingen 86

5.4.2 verhoging van competentie-verwachtingen $\quad 87$

5.4.3 Generalisatie van competentie-verwachtingen $\quad 89$

5.4.4 Versterking van competentie-verwachtingen 89

6. De ontwikkeling van vaardigheidsmeters (Sklms) 90

6.1 Constructie 91

6.1 .1 Item-constructie 91

6.1 .2 Factor-analyse 92

6.1.3 A- en B-Skims 93

6.2 Betrouwbarhej.d en stabiliteit 94

6.3 Criteria voor de validiteit $\quad 95$

6.3.1 Criteriumvaliditeit van gedragsobservaties 96

6.3.2 Keuze voor simulaties 97

6.3.3 Keuze wan criteria 97

6.3.4 Angst en hartslagfrequentie 98 
6.4 opzet eerste valialteltsstudie

6.4 .1 De sinulaties

6.4 .2 proefpersonen

6.4.3 Angstmetingen

6.4. 4 Gedragsbeoordellingen

6.4.5 Dataverwerking

6.5 Resultaten

6.5 .1 Gedragsbeooxdelingen

6.5 .2 sociale angst

6.5.3 Angst the mometer

6.5 .4 Harts lag

6.5.5 Relaties tussen de angst-indicatoren 108

6.6 Een tweede validiteltsstudie 109

6.6.1 Gedragsbeordelingen 110

6.6.2 Angstmetinger 111

6.7 Discussie en conclusies 111

6. 7.1 'Iypen onvaardigheid en de Skims-batterij 112

6.7.2 De criteriumvaliditeit van "video-simulaties" 113

6.7.3 De validiteit yan de Skims 113

7. Effecten van interpersoonlijke waardigheidstherapieün voox kansarmen

7.1 Criteria en meetinstrumenten 116

7.1 .1 Vergroting van intexpersoonlijke vaardigheden $\quad 116$

7.1.2 Reductie wan specifleke klachten 117

7.1.3 Vergroting van zelfwaardering 118

7.1.4 Reductie van algemene klachten 119

$\begin{array}{ll}7.2 \text { Proefpersonen en data-verzameling } & 120\end{array}$

$\begin{array}{ll}7.2 .1 \text { Experimentele groep } & 120\end{array}$

$\begin{array}{ll}7.2 .2 \text { Controle-groep } & 121\end{array}$

7.2 .3 Tijdstippen en witze van data-verzameling 122

7.2 .4 Herhalde nameting (follow-up) 124

7.3 Dataverwerking en resultaten 125

7.3 .1 Efecten op (on) vaardigheid A 125

7.3.2 Effecten op (on) waardigheid $B \quad 129$ 
7.3.3 Effecten op specifieke klachten 131

7.3.4 Effecten op zelfwaardering 133

7.3.5 Effecten op algemene klachten 134

7.3.6 Effecten van meerdere deelnamen 136

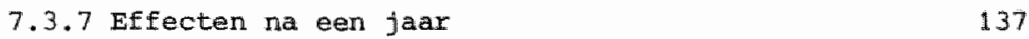

7.4 Discussie, conclusies, samenvatting 138

7.4.1 Verandexingen in A- en B-vaardigheden 138

7.4 .2 Doelgebonden resultaten 140

7.4.3 Doelvrije resultaten 141

7.4 .4 Samenvatting $\quad 142$

Nawoora 143

Samenvatting 145

Summary 150

Literatuur 155

Bijlagen 169

Bijlage 1: Verwijzen naar Goldsteintherapieän 169

Bijlage 2: Beknopt draaiboek therapieern 174

Bijlage 3: A-Skims, $1 \mathrm{~A} t / \mathrm{m} 9 \mathrm{~A} \quad 178$

Bijlage 4: B-Skims, 2B, 4B, 5B en $8 B \quad 187$

Bijlage 5: Score-verdeling op skims 191

Bijlage 6: Zelfwaarderings (SE) schaal 192

Curriculum vitae 


\section{INLEIDING}

Eind 1977 is het 'Goldsteinproject' van start gegaan.

Dit project tracht bijaragen te leveren tot de ontwikkeling van de geestelifke gezondheidszorg voor zover die zich richt op de hulpverlening aan clienten uit lagere sociaal-economigche klassen. Deze cliënten zijn vaak moeliljk te helpen met traditionele -verbale, inzichtgevende- psychotherapeutische methoden. Het project bouwt voort op het werk van de Amerikaan Arnold Goldstein die voor de genoemde doelgroep de 'structured learning therapy' ontwikkelde: een koxtdurende directieve therapte-methode, dile goed aanslut bij de verwachtingen en mogelijkheden van clienten van laag ontwikkelingsniveau. Deze methodiek maakt gebruik van gedragstherapeutische procedures en beoogt clienten vaardigheden te leren en daarmee hun draagkracht te vergroten.

Dit proefschrift bevat een weergave van onderzoekingen en ontwikkelde protocollen voor zover behorend tot een pakket 1 interpersoon 1 jke vaardigheidstherapieër woor clienten in de ambulante geestelijke gezondheidszorg.

Over andere eveneens door het Goldsteinproject geoperationaliseerde programma's (vaardigheden doelmatig hardelen, vaardigheder voor partner en een voorberelaingsprogramma voor clieuten met psychosomatische klachten), alsook over toepassingen blj andere doelgroepen (zwakzlnnigen, gehospitaliseerden, verslaafden) zal eldexs gepubliceerd worden.

In dit inleldende hoofdstuk wordt nader lingegaan op de relatie tussen de hedendaagse psychothexapie en cliënten ult lagere sociaal-economische 
klassen, de pogingen aie elders werden en worden ondernomen om de geconstateerde kloof te overbruggen, de basiselementen van coldstein"s "stuctured learning therapy" en de bexelkbaarheid van de RIAGG"s in ZuLa-Limburg.

In hoofdstuk 2 komen recente ontwikkelingen in de sociale leertheorie en hun mogelijke consequenties voor interpersoonlijke vaardigheiastherapieen aan de orde. In hoofdstuk 3 wordt een onderzoek beschreven, al tgevoexd tex onderbouwing van de keuze van interpersoonlijke vaaralgheden. Hoofdstuk 4 betreft ontwikkelingen in en ervaringen met modeling-banden, terwlj1 hoofdstak 5 een compacte beschrijuing en verantwoording omvat van de therapteprograma" $s$. Hoofdstuk 6 , over de ontwikkeling van een batterlj interpersoonlijke vaaxdigheidsmeters, vormt de aanloop tot het laatste hoofdstuk, dat handelt over de effecten wan toepassingen van de ontwikkelde programm's bij RIAGG-cliënten.

\subsection{Kansarmen in de psychotherapie *}

In vergelijking met psychotherapie-cliënten wit de hogene sociale klassen hebben (kandidaat-) clienten uit de lagere klassen een grotere kans

- niet geschikt te worden bevonden voor behandeling,

- lang op de "wachtlijst" te staan.

- af te vallen na intake,

- een sodaal ongewenste diagnose te kxijgen.

- toegewezen te worden aan minder ervaren therapeuten,

- verwachtingen te koestexen die niet congruent zijn met die van de thexapeut.

- cen onvolwaralge relatie te ontwikkelen met hun therapeut,

- de relatie met de therapeut voortijdig beeingigd te zien, en

- minder voorultgang te boeken.

* Over dit onderwerp is eerdex gepubliceera door Beekers. Beckers, Bongaarts en Paters (1980). 
Met deze constateringen, geput uit Amerikaans onderzoek, start Arnola Goldstein zijn boek "structured Learning Therapy - towand a psychothexapy for the poor' (1973). In dit boek beschrijft Golastein de miserabele positie die clienten uit de lagere sociaal-economische lagen van de Amerikaanse bevolking innemen ten opzichte van de hedendaagse psychotherapie, gaat vervolgens op zoek naar de oorzaken en presenteert een mogelljke oplossing, in de vorm van een meer op deze doelgroep toegesneder methode van psychotherapie.

Goldstein staat niet alleen in $z i j n$ constatering, dat ook de wereld van de psychotherapie kansarmen kent. Hollingshead en Redich (1958) toonden aan dat langdurige psychotherapie en psychoanalyse bijna uitsiluitend werden toegepast bij cliënten uit de hogere klassen. Van psychotische patienten uit de laagste sociale klassen werd bovendien een disproportioneel groot aantal chronisch opgenomen en behandeld met elektroshocks. Meltzoff en koxnrelich (1970) vonden eveneens dat mensen uit de lagere maatschappelijke klassen nawwelijks profiteren van de gangbare psychotheraplesystemen.

Dit wringt des te meer daar "psychological disorders" het meest Exequent voorkomen in de lagere sociale klassen (Dohrenwend en Dohrenwend, 1969). Nijhof (1979) komt in een onderzoek onder Nedierlandse mannen naar de samenhang tussen ongelijkheid in levensomstandigheden en psychische gezondheidsklachten tot de bevinding dat psychische stoornissen, en dan met name 'psychosomatische" en "algemeen psychiatrische' klachten, meex voorkomen in lagere dan in hagere sociale strata. Met name de "interpretatie' van zijn matschappelijke positie blijkt voor de kansaxme wan belang: het matschappelljk problewin van ongelijkheid blijkt door velen in de onderlaag gedefinierd te worden in termen van een persoonlijke zelfdepreciatie. Deze 'subjectluering' van sociale stratiflcatie blijkt een voedingsboden voor psychische gezonaheidsklachten te zijn.

ormel (1981) kont in een eveneens Nederlands onderzoek tot de conclusie dat lager geschoolaten zowel zwaaxder belast worden als een gerlngexe belastbaarheid hebben dan hoger opgeleldenen. 
De typlsche psychotheraple-client is door Schotield (1964) spottend angedula dis mx. Yavis. Mx. Yavis is young, attractive, verbal, Intel11gent en successful. Clianten uit de lagere social-economische klassen zljn doorgaans niet-Yavis, en worden wel getypeerd als Hounds: humble, old, unattractive, non-verbal en dull. zij beschikken over mindere vemogens tot verbalisatie en Introspectie (Riessman, Scribner, 1965). zij hanteren een andere taal dan de therapeut (Bernstein, 1964). en eer warden- en normenpatroon dat afwijkt van dat van de middenklasse (Cole, Branche en Allison, 1962), terwijl de hedendaagse psychotherapie wortelt in de waxden en nomen van die middenklasse. zij verwachten eexclex eer (medisch) recept dan non-directieve cesprekken waarin een beroep wordt gedaan op hun eigen verantwoordelijkheld en initiatief. Zij zijn minder lnteliligent, hebben een geringer abstractie-vermogen, minder fantasie, minder inlewingsvermogen (Jones, 1974). Hun geringere motivatie tot thexaple kan gekoppeld worden aan een gebrek aan succesexvaxingen in het verleden. Veranderingen ervaren zij als van butenaf bepald en riet door eigen inspanningen en controle (Rotter, 1966; Scott en Phellan, 1969).

In Nederland is ex weliswaar minder onderzoek gedaan naar de relatie tussen de sociale klassen en (de behoefte aan) psychotherapeutische hulp, doch ook hier lijkt ex sprake te zijn wan eer ongewenste achterstelling van de lagere sociaal-economische strata. De bevolking van onze psychiatrische ziekenhuizen makt niet bepaald de indruk een evenredige afspiegeling te zijn van de diverse soclale lagen in de samenileving; minderbedeelaen zijn er duidelijk oververtegenwoordigd. De Instituten voor Multidisciplinalre Psychotherapie (IMP-en), die in Nederland als centrale furitie hebben het verstrekken van gestructureerde psychotherapie, kampen met een onbedoelde sociale selectie waardoor de lagere sociaal-economische strata nauwelijks berelkt worden (stuurgroep Maatschappelijke Spreiding Psychotherapie, 1976). Van der Velden en vreeken (1977) stellen dat de hulpvragex an te kunnen worden opgenomen in de subcultuur van de hulpverlener in veel gevallen dient te beschikken over zaken als "verballe begaafaheid" of 'vermogen tot introspectie', die meestal sterker te vinden zijn naarmate de hulpvrager een betere opleiding en dito inkomen heeft. Dit 
geldt zeker voor het in ons Land ruime aanbod aan "inzichtgevende psychotheraple'.

Het Amsterdamse IMP noemt in zijn verwijzingsbrochure onder meer de volgende indicaties yoor deze vorm van psychotherapie (Van Dantig. 1978):

- de client heeft het gevoel dat zijn klachten, symptomen of problemen op de een of andere manier te maken hebben met zijn eigen gevoelsleven (ziekte-inzicht)

- hij is in principe genegen en in staat, zich in zijn eigen belevingswereld te verdiepen (introspectie).

Voor de doox dit IMP eveneens aangeboden gedragstherapieenn worat weliswaar 'introspectie en redelijke intelligentie niet noodzakelijk' genoemd, wel moet ex" een 'belangrijke eigen motivatie van de client zijn on tot gedragsverandering te komen en moeten ex troldoende mogelijkheden zijn om met hem samen te wexken'. Hoger opgeleidenen hebben ex dan ook een grotere kans voox psychotherapie geaccepteerd te worden dan minder geschoolden (Schutz, 1981).

\subsection{Fogingen tot overbrugging van de kloof}

Hoewel de genoemde constateringen de indruk zouden kunnen wekken dat psychotherapeutische hulp door de verstrekkers ervan bewust wordt voorbehouden an een bepaalde elite van onze samenleving, is dit niet het geval. Zo hebben in Nederland de IMP-en van oudshes de paychotherapeutische behandeling van 'mindervermogenden' als doelstelling gehanteerd. Diverse aktiviteiten zijn door hen ondernomen om de lagere klassen meer te bereiken.

In 1974 stelde het directeuren-overleg IMP-en een "overleggroep mataschappelijke spreiding psychotheraple" in. Gedacht werd toen aan uitbreiding en wijziging van het pakket aan psychotnerapeutische technieken en aan verbetering van ae bereikbaarheid van de IMP-en. Al snel bleek. dat de meerderheid wan de overleggraep ex, op basis van eigen ervaringan, vanuit ging dat de "traditionele" psychotherapeutische technieken wel. degelijk ook geschikt waren voor de minderbedeelden in de samenleving. 
De vanut de overleggroep geformerde stuurgroep introduceerde in 1976 het begrip Libo-cliênt. Libo-cilënten Hebben en Lager irikomen, beroepsprestige gpleidingsniveau, respektievelijk en netto inkomen van minder dan 2 $^{24.000,--}$ per jaar (naar de normen van 1974), arbeider of lager employe (of gezinsieden daarvan) en lager onderwijs plus ten hoogste 3 jaar vervolgonderwis. De stuurgroep kwam op grond van beschikbare gegevens tot de schatting dat de Mederlandse bevolking voor 35 a 45 ult Libo" s bestaat, terwijl deze Libo's slechts 3 a $5 \%$ uitmaken van het cllentenbestand van de rMP-en (Stuurgroep Matschappelijke Spreiding Psychotherapie, 1976\%. Gesproken werd over 'een discriminatiefactor van 7 a 15 , zeg 10'. De stuurgroep kiest dan voar een 'retroalscrintuatoor beleid", bedoeld om via stimulering en correctie van het varwijuingsnetwerk, vereenvoudiging en bespoediging van interne toewijzingsprocedures, herziening van contra-indicaties voor Libocllënten, aanwljzing van een Libo-coördinator pex IMP, registratie, en uitwisseling en vastlegging van opgedane ervaringen de onbedoelde sociaal-selectieve effecten te compenseren.

Het Utrechtse IMP, warvan blijkens een steekproef-onderzoek het cliëntenbestand voor slechts $4 \%$ uit Libo"s bestaat (Stuurgroep Maatschappelijke Spreiding Psychotherapie, 1978), experimenteert met een door stufkens (1977) samengestelde introductiecursus voor psychotherapie. Hiemee wil men onder meer tegemoet komen aan problemen die libo-cliënten vaak hebben in de beginfase van het contact met instituut en therapeut.

Daarmee komen we terecht in de sfeer van aangepaste of aanvuliende technleken, die beogen de kloof tussen de psychotherapeutische cultuur en die van de minderbedeelden te dichten.

Pljpe (1976) pleit voor en experimenteert met diverse "voorbereidingstechnleken', zoals het voorbereldend interview en de vooxbereidende fllm, die de psychotherapie meer toegankelijk zouden kunnen maken voor de clisernt van laag ontwikkelingsmiveau. Hetzelfde wordt door hen beoogd me en aantal methoden tot activering tijdens de therapie: de vragenlijstmethode, "metered counseling" en het wisselend leiderschap. Meillo en Goedhart (1980) passen in hun groepstherapieen voor kansarmen een mengeling van dramatechnieken toe, die door hum aznschouwelijk en concreet karakter geschiktex worden geacht voor de doelgroep dan 
verbale technieken.

Degenen die aangepaste technieken voorstaan, wijzen daambij vaak op de bij de lagere klassen wèl aanwezilge eigenschappen, die een positief potentieel voor psychotherapie zouden kunnen zijn. Zo wijzen Riessman en Scribner (1965) op het geconstateerde ontbreken van de neiging tot rationaliseren en intellectualiseren. De waarden en normen van de lagere klassen zouden bovendien niet als deficlënt, naar juist als consistent met de eigen sociale structuur van de arbeidersklasse moeten worden bezien (Miller en Riessman, 1961). Cliënten uit de lagere klassen zouden tevens emotioneel-expressiever zijn (Gould, 1967). Rapaport (1962) pleit voor lower class-psychotherapieën, die 'rehearsal for reality' mogelijk maken. Schmidt, Smart en Moss (1968) menen dat deze cliënten eerst geleerd moet worden zich te verdedigen, adequat te reageren en in een later stadium hoe te ageren; in dat kader spreken $z i j$ van een ontwikkeling van zelfhamdhaving naar zelf-actualisatie. ook Van dex Velden (1977) is de mening toegedaan dat men dient te probexen de therapie aan te passen aan de cliënt, en dan met name aan 'de grote groep gewone psychiatrische patienten'. Veel cliënten hebben als voornaamste behoefte vermindering van klachten op korte termijn, hetgeen vxaagt om pragmatische, doelgerichte en kortdurende therapeutische werkwijzen. In "Directieve therapleen" (Van der Velden, 1977) beschrijven 7 therapeuten de essenties van en exvaringen met korte directieve therapieën, waarvan Van der Velden en Vreeken (1977) stelien dat er geen reden is om aan te nemen dat alle cliënten ermee greholpen kunnen worden, maar wel dat net deze benadering meer mensen hun recht op adequate hulp kunnen realiseren dan met de klassieke psychotherapeutische voorzieningen het geval is.

Goldstein (1973) komt op basis van uitgebreide literatuurstudie tot de conclugie dat een aan de lower-class-cllënt aangepaste psychotheraple moet voldoen an de volgende criteria:

- kortarurend,

- airectief.

- nadruk op concreet gedrag,

- beroep op conformiteit aan concrete voorbeelden,

- gebrulk van role-taking-training, 
- Erequente, voorturcende en ormidallijke bekrachtiging,

- minimal gebrulk van complexe of abstracte verbalisatie,

- gexicht op uitbrelaing van gedragsrepertoires.

Wijngaraten (1978), dle betrokken ls geweest bij een stuk ontwikkelingswerk an Goldstein'a methode (Goldstein, Goedhart en wijngaarden, 1973), is de overtuiging toegedaan dat zelfs de meest geëigende therapeutische technieken voor de arbeider-client slechts een "lapmiddel' kunner zijn. De levenssltuatie van de arbeider lat immers zo weinig ruinte tot zelfbeschikking, at slechts politieke oplossingen (betere spreiding van opleiding, kennis, macht en inkomen) wezenlijk kunnen bijdxagen tot grotere zelfsturing. Tegelijkertijd meent Wijngaaxden dat een grotere practische ruimte woor zelfbepaling nilet automatisch lejut tot realisering van meer zeggenschap over eigen gedrag. Men kan aan deze stellingname de conclusie verbinden dat een aan de arbeider-client aangepaste psychotherapie slechts kan pretenderen de client te leren:

- de aanwezlge ruimte tot zelfbepaling beter in te schatten

- deze ruimte tot zelfbeschikking beter te benutten.

\subsection{De methode van Goldstein}

Arnold Goldstein (1973) ziet zijn 'structured learning therapy' als een methodiek, die tegemoet komt aan de behoeften, leefwijze en Leefwereld van de lower-class client. Zijn methode is gericht op het vergroten van vaardigheden. Via het aanleren van vaardigheden wordt beoogd client"s autonomie, assertivitelt, interne controle, accuraatheld wan waarmemen en communiceren, tolerantie voox frustratie en amblguiteit te vergroten, om hem beter opgewassen te doen zijn tegen de elsen die het (dagelijkse) leven hen stelt.

Deze vaardigheden (skiIls) worden de clienten aangeleerd via modeling, gedragsoefening, sociale bekrachtiging en transfer-training (Goldstein, Sprafkin on Gershaw, 1976). .

Dit gebeurt in groepen die, afhankeliyk van het niveau van de groep en van het aantal en de complexitelt van de vaardigheden, 3 tot 15 
zittingen in beslag nemen.

Bij de keuze en nadere operationalisatie van de hoofacomponenten van zijn methode refereert Goldstein aan een groot aantal onderzoeken. Samengevat laten deze componenten wioh als volgt beschrijwen (Goldstein, 1973; 1976; 1981).

\section{3 .1 Modeling}

De clienten wordt een aantal voorbeelaen getoond van de vaardighela c.q. van de specifieke gedragingen waruit de vaardigheid bestaat. Dit kan in principe gedemonstreera worden dook de therapeut, maar ook via gellidsbanden, videobanden of films.

Rekening kan gehouden worden met de bevindingen dat modeling effectlever is naamate het model (degene die de vaaraigheld demonstreert) voldoet aan de volgende kenmerken:

- een meer bedreven of deskundige indruk maakt

- een hogere status heeft

- meer overeenkomst heeft met de cliënt, doordat het model van hetzelfae geslacht is, van dezelfde leeft.jd, e.d.

- vriendelijk en behulpzaam is

- positieve gevolgen blijkt te onderwinden ten gevolge van het stelien van het gedrag.

Voor het getoonde gedrag geldt dat het beter aangeleerd wordt naarmate:

- het gedrag duldelijk en gedetalleerd is

- het meerdere malen wordt getoond

- de volgorde van de voorbeelden verloopt van gemakkelijk nar moeilijk

- irrelevante gearagingen worden weggelaten

- verschillende modellen het gedrag tonen.

\section{3 .2 Gedragsoefening}

De cliënten worden in de gelegenbeid gesteld en gestimuleerd on de gedemonstreerde gedragingen zelf wit te voeren binnen de therapeutische setting. Aanvankelijk wordt gestreef naar imitatie van (delen van) het gedemonstreerde gedrag. Geleidelijk aan worden aan de cliënt hogere 
elsen gesteld, in die zin dat in toenenende mate het stellen wan de volledige vadudigheld (meerdere gedragselenenten tegeijjkertija) wordt verlangd, dat rollenspelsituaties in moeilijkheidsgrad toenemen, en dat er sprake ls van een verschulving van imitatie van andemans gedragingen naar meer persoonlijke versies van de an te leren vaaraigheld in door de cliënt zelf aangedragen, voor hem relevante situaties. Goldsteln nowt als condities die het leren door gedragsoefening optimaliseren:

- de mate warin de cllënt het participeren in het rollenspel meer erwart (erwaxen kan) als zijn eilgen keuze;

- de mate van 'commitment' van de client aan het door hem gestelde gedrag, vrij te vertalen als de mate waarin dat gedrag meer 'van hemzelf' 1 s en moellifkex 'ongedaan' gemaakt kan worden;

- de mate van improvisetie, d.w.z. de mate warin de client zonder voorberelding en zonder gedetailleerde aanwjzingen de vaardigheid gestalte weet te geven;

- de mate waarin het te leren gedrag bijval, beloning of "bekrachtiging" ter deel valt.

\subsubsection{Bekrachtig. ing}

De clienten dienen voorturend te ervaren dat uitwoering van de vaardigheid gepaard gaat met positieve terugkoppeling, sociale bekrachtiging, instemming, bijval en enthousiasme. Reeds in de modeling-fase wordt het model. 'beloond'. Tijdens gedragsoefeningen lis er voortdurend sprake van goedkeuring: elke daad wan de cliënt die (meer) beantwoordt aan het doelgedrag (de vardigheid) verdient aandacht en bijval van de therapeut on de groepsleden. De bekrachtiging is effectiever naarmate rekening wordt gehouden met de volgende factoren:

- type bekrachtiging. DAt heeft betrekking op de behoeften en eventwele verzadiging van de cliënten. Niet ledereen vindt hetzelfde prettig, en wat prettig is kan ook overgedoseerd worden. Naast sociale kan ook materlele bekrachtiging aangewend worden.

- moment van bekrachtiging. Doorgaans geldt dat de bekrachtiging het meest efectief is, als zij onmiddellijk volgt op het optreden varn het gewenste gedrag. Uitstel kan leiden tot het onbedoeld belonen van 
irrelevant of zelfs ongewenst gedrag, dat optreedt tjaens de uitstelperiode.

- 'respons-contingente' bekrachtiging. Kwantiteit en kwallteit van de bekrachtiging dienen evenredig te zin aan de 'prestatie' wan de cilênt.

- dosering van bekrachtiging. Hoe sterker de bekrachtiging, hoe groter het leereffect. Tegelijkertija echtex geldt dat toename van bekrachtiging in afnemende mate de prestaties verhoogt. Het blijkt dat leren aanvankelijk niet verbetert doox onvangrijker bekxachtiging. terwijl. in een later stadium het lexen meer afhankelijk wordt van deze onvang.

- gelegenheid tot bekrachtiging. Het te bekrachtigen gedrag dient voldoende frequent gelegenheid te krijgen gesteld te worden. Alleen dan kan de cliênt zijn 'beloning veraienen'. De client dient dus voldoende kansen (beurten) te krijgen in de gedragsoefening.

- onderbreking van bekrachtiging. Indien men beoogt dat het nieuw verworven gedrag bekiljft, dan moet tijdig worden overgeschakeld op onderbroken bekrachtigingsischema's. Het gedrag moet resistent worden tegen uitdoving; dat wordt het door geleidelijk aan niet meer elke gewenste respons te belonen, maax over te stappen op een vaststand of variabel partieel bekrachtigingsschema.

\section{3 .4 Transfer-training}

De modeling, gedragsoefening en bekrachtiging dienen zodanig te worden toegepast dat de cliënt het nieuw verworven gedrag ook blijwend zal gaan toepassen in zijn dagelijks leven bulten de thexplesetting. Bij het 'modelen" wordt de cliênt gedemonstreard dat de te leven valudgheid in meerdere leefstuatles gesteld kan worden. Bil gedragsoefeningen wordt geleldelijk aan meer gewerkt met leefsituatles, die de client zelf inbrengt. Bovendien wordt 'hulswerk' opgegeven: de clidnt krijgt opdrachten mee die de toepassing van de te leren vaarajgheld in zijn eigen lexen bevorderen. De mate waarin generalisatie zal optreden kan beinvloed worden door rekening te houden met de volgende principes: 
- algemene inzlchten. De generalisatle zal bevordera worden als de client inzlcht verwerft in de algemene principes die het beoogde gearag kenmerken, zowel in de therapiesetting als daarbuiten. Marmate de client deze algemene Inzichten meer zijn duidelijk genaakt, zal hif in latere onvoorziene situaties eerder 'herkennen' wat hem overkomt en weten wat hem te doen staat.

- beschikbaarheld van gedrag. De waarschijnlijkheld dat een bepaald gedrag optreedt, neemt toe naarmate dat gedrag in het verleden meer gesteld 1s. 'Overlearning' tijdens de therapie komt dan ook de genexalisatie ten goede.

- Identieke elementen. Naarmate de therapiesituatie en de leefsituatie van de cliënt meer overeenkonsten vertonen, zal latere toepassing van het geleerde gedrag meer waarschijnlijk zijn. Ver doorgevoerd betekent dit dat het effectiever is de client het gedrag aan te leren in zijn eigen leefsituatie (s) dan in een thexapie-centrum tussen vreemden.

- stimulus-variatie. Generalisatile wordt bevorderd als de client geleerd heeft de vaardigheid toe te passen in een zo breed mogelijk seala van stimulus-situaties. zo zal generalisatie van interpersconlijke vaardigheden toenemen naarmate de cliênt het te leren gedrag geoefend heeft tegenover uiteenlopende typen tegenspelers.

- Feedback. ook buiten de theraplesetting is correctieve feedback en (onderbroken) bekrachtiging bevorderlijk voor het beklijven van het geleerde gedrag. Gedacht kan daarbij worden aan het inschakelen van hulpverleners, huisgenoten of vrienden, aan voortgezette contacten tussen (ex-) cliënten en aan afspraken ontrent zelf-bekrachtiging.

\subsubsection{De vaardigheden}

Aanvankeliyk stelde Goldstein (1976) een set van 37 basisvaardigheden en 22 toepassingsvaaxdigheden samen. Een toepassingsvaardigheid is een samenvoegsel $\operatorname{van} 3$ tot 8 basisvaardigheden in een zodanige volgorde en comblnatle dat volledig tegemoet wordt gekomen aan een waar levensprobleen. Een voorbeeld van een toepassingsvaaralgheid, ter illustratie (letterijk vertaald): 
(vaardigheid 38) - HET VINDEN VAN EEN WONING

1. een doel stellen

2. hulp vragen

3. instructies opvolgen

4. informatie verzamelen

5. reageren op uitgeoefende druk

6. anderen overtulgen

7. een besluit nemen

8. ondexhandelen.

Elke basisvaardigheid wordt beschreven in een antal ( 3 ì 7 ) "leerpunten'. "Twee voorbeelden daarvan:

(vaardigheid 23) - EEN DOEL STELEN

1. ga na wat je zou willen bereiken

2. ga na wat je zou moeten doen om dit gewenste doel te bexelken

3. ga na in welke volgorde je deze zaken zou willen aanpakken

4. beoordeel of je planning haalbaar is

5. stel een halbaar doel vast.

(vaaxdigheid B) - HULP VRAGEN

1. stel vast met welk probleem je zit

2. beslis of je hulp wilt zoeken

3. ga na wellke mensen je zouden kunnen helpen

4. kies een helper

5. vertel de helper wat je probleem is.

Goldstein spreekt zich overigens niet uit over de wijze warop hij tot de keuze en samenstelling van de diverse vaardigheden is gekomen. Later, als hij zijn methode toepast bif adolescenten, zijn diverse vaardigheden inhoudelijk gewijzigd of weggelaten, andere zijn arn het pakket toegevoegd (Goldstein, Sprafkin, Gershaw en KIein, 1980 .

\subsubsection{Geludasbandien als therapeutigch hulpmiddel}

Teneinde een zo uitputtend mogelijk gebruik te kunnen maken van -bovengenoemde- 'modeling-enhancers' heeft Goldstein geluidsbanden samengesteld die een modeling-functie vervulien. Elke band is als volgt samengesteld: 
1. Een inleider met een hoge status (dokter, zilekenhusidirecteur) Introduceert zichzelf en vervolgens de valudigheld wat het in betreffende band on gaat.

Van de vaardigheld noemt hij de naam, geeft een algemene beschrijving en een beschxijving in min of meer concrete gedragstemen (leerpuntenl. Vervolgens geeft hij aan hoe en waarom de aanwezigheid wan deze vaardigheld lonend kan zijn, geeft woorbeelden van het ontbreken van de vaardigheid en hoe en waarom dit fnuikend kan $z i j n$, herhaalt de leerpunten nog eens en vraagt andacht voor de komende voorbeelden.

2. Een tiental korte 'hoorspelen' volgen, waarin steeds de complete reeks leerpunten waaruit de vaardigheid bestaat, wordt toegepast. Een grote vexscheidenheld aan acteurs (modellen) en situaties worden daarbij aangewend. De acteurs hanteren eenvoudige spreektaal. De toepassing van de vaardigheld leidt steeds tot sociale bekrachtiging.

3. De inleider hexhalt tensilotte nog eens de leerpunten, beschrijft de gunstige gevolgen die de cliënten kunnen verwachten van toepassing van de vaardigheid en dringt aan op (be) oefening van de leerpunten in de groep en, daarna, in de eigen leefsituatie.

Op deze wijze slaagt Goldstein erin alle bekende model- en modelingvariabelen, waarvan bekend is dat zij het leren bevorderen, en die soms onderling tegenstrijdig lijken (hoge status versus zelfde status), op effektieve wijze aan te wenden. Bovendien wordt rekening gehouden met de principes van bekrachtiging en transfer-training.

\subsection{Goldateintherapieen voor Limburgse kansarmen}

Ednd 1977 lis ex een projectgroep geformeerd, bestaande uit medewerkers van de groep Medische Psychologie van de facultelt der geneeskunde van de Rifksuniversitelt Limburg, het RIAGG Mastricht en comstreken, het RIAGG Oostelijk Zuid-Limburg (Heerlen en onstreken) en de Toneelacademile Mastricht, met als taak het operationeel maken van Gold-stein's 'structured learning therapy' ten behoeve van de kansarmen 
in de regio. De araleiding tot de formatle van deze projectgroep was de in beide genoemde RIAGG's gesignaleerde behoefte aan aangepaste hulpuexleningsmethodieken voor clienten ult lagere sociaal-economische klassen, en dan met name een behoefte aan kortdurende vaardigheidstherapieen ter ondersteuning van c.q. aanwulling op gangbare gesprekstherapieen.

\subsubsection{RIAGG-bereikbaarhe1d}

Men kan zich afuragen of de RIAGG's de aangewezen plaats zijn van waaruit deze vaardigheidstherapieën an de doelgroep moeten worden aangeboden. Ten aanzien van instellingen voor geestelijke gezondheldszorg bestaat er immers ook een bereikbaarheids-c.q. drempelprobleem (zie 1.1 en 1.2). Is het wellicht nodig een alternatief circuit op te zetten of via instellingen woor matschappelijk werk of buurt-opbouwwerk de doelgroep te bereiken? Is de bowengenoemde behoefte in de RIAGG"s slechts het gevolg van ervaringen met een handjevol "moejlijke" Hubo-cliënten?

Getracht is deze vooraf-vraag te beantwoorden met behulp van beschikbare cliënten- en bevolkingsgegevens. Als daaruit zou kunnen worden afgeleia dat mensen uit lagere sociaal-economische klassen voldoende vertegenwoordiga zouden zijn in het cliëntenbestand van de RIAGG"s, dan zou de implementatie van de te ontwikkelen vaardigheidstherapieen in de RIAGG's zin hebben en zou bovendien de projectgroep veel werk, gericht op verhoging van de bereikbaarheid, bespaard blijven.

Het RIAGG Maastricht en omstreken bleek een clidentenregtstratlesyteem te hanteren waarin twee klasse-indicaties van clienten woorkwamen, namelijk:

- het opleidingsniveau, en

- het type ziektekostenverzekering.

Het type ziekte-kostenverzekering kan als (waardevaste) index voor het lnkomensniveau gehanteerd worden, geziende verplichting tot zlekenfondswerzekering bij lagexe inkomens.

In tabel 1.1 worden opleldingsniveau's wan bewoners van zuidelijk Limburg en van de totale Nederlandse bevolking vergeleken met die van 
RIAGG-cilenten. Het trekken van conclusies wordt bemoeilijjkt door de grote orvang van de categorle "opletding anderszins of onbekend' en doordat de in de tabel voorkonende cijfers op niet-gelijke regio's betrekking hebber.

Tabel 1.1 Opleidingsniveau (percentages)

Lager opleiaingsniveau (lagex dan MAVO)
Middelbaax en hoger opletdingsniveau (MAVo en HAVO)
Anderszins of onbekend

\section{Neder landse be-}

volking* 1971

40.6

38.4

21.1

Grote gementen zuldelifk Limburg * *

43.1

34.9

22.1

1971

Kleine gemeenten zuidelijk Limburg 1971

RTAGG-cllënten *** 1975

RIAGG-cliënten

1977

60.1

34.0

5.9

De gegevens zijn geput uit een verslag van een onderzoek naar het vormingsen ontwikkelingswerk voor volwassenen in de regio zuidelijk Limburg (Samenlevingsopbouw zuidelijk. Limburg, 1978) en de registratiegegevens 1975,1976 en 1977 van de SGGZ (Decker, Van Ham en Vroemen, 1978).

De ciffers zijn gebaseerd op CBS-gegevens over de volkstelling 1971 en hebben betrekking op 17-jarigen en ouder. CBS-volkstelling 1971, 17-jarigen en ouder. Het betreft de gemeenten Maastricht, Heerlen, valkenburgi en Vaals. CBS-volkstelling 1971, 17-jarigen en ouder. Het betreft de 16 klledne gemeenten in zuldelijk Limburg (de driehoek EijsdenVeals-Bunde).

*** De RIAGG-regio omvat 3 van de 4 genoemde grote gemeenten (Heerlen niet) en 19 kleine gemeenten. Van deze kleine gemeenten vallen er 15 in de categorie 'kleine gemeenten zuidelijk Limburg', zoals die in de tabel vooxkomt. 
Toch suggereren de cijfers dat lager opgeleiden met 60 eerder overdan ondervertegenwoordigd zijn in de Maastrichtse RIAGG-oliantenpopulatie, temeer omdat in de perlode 1971-1977 het opleidingsntveau van de bevolking verbeterd zal zijn.

In tabel 1.2 zijn de aan inkomen verwante verzekeringstypen vergeleken. Verplicht verzekerden lijken oververtegenwooraigd in het clientenbestand, hoewel aok hier hetzelfde roorbehoud gemakt moet worden als bij de vorige tabel.

Tabel 1.2 Type verzekering (percentages)

\begin{tabular}{lccc}
\hline & $\begin{array}{l}\text { Verplicht } \\
\text { ziekenfonds }\end{array}$ & $\begin{array}{l}\text { Particuliex } \\
\text { verzekerd }\end{array}$ & $\begin{array}{l}\text { Anderszins } \\
\text { of onbekend }\end{array}$ \\
\hline $\begin{array}{l}\text { Reg10* } 1976 \\
\begin{array}{l}\text { RIGG-populatie ** } \\
1977\end{array}\end{array}$ & 57.1 & 25.9 & 17.0 \\
\hline
\end{tabular}

Deze cijfers zijn afkonstig lit het jaarverslag 1976 wan de Stichting over leg Limburgse Ziekenfondsen, en hebben betrekking op de MRC-regio van ruim 600.000 inwoners. Daarbinren vallen 3 RIAGG's (Maastricht, Heerlen en sittard).

* Uit de registratiegegevens var het RIAGG Maastricht e.0. , 1977 (Decker, e.a., 1978).

Zowel mindergeschoolden als mensen met lagere inkomens zijn in ruime mate vertegenwoordigd in het cliëntenbestand van het RIAGG Maastricht en omstreken.

Wellicht juist daardoox is de onmacht van de hulpverleners ten opzlchte van cliëten uit lagere soclaal-econonische klassen en daarmeg de vraag naar aangepaste of aanviliende methodieken sterk aan het licht gekomen. Implementatie van de te ontwikkelen vaardigheidstherapleen in de Limburgse RIAGG's mag zinval worder geacht (waarmee toepassingen elders niet worden uitgesloten). 


\section{4 .2 Het Golastelnproject}

Het operationeel maken van coldstein's "structured learning therapy" kan niet afgedaan worden wet het vertalen van thexapeutische hulpmiddelen en het (doen) opstaxten van therapie-groepen. De sociale leertheorie, warop Goldstein"s methade is gebaseerd, is sterk in ontwike11ng. Het was on is nookzakelijk deze ontwikkelingen te volgen, en, waar nodig, nieuwe inzichten te verwerken in de vardigheidstherapiean. Dadrnaast werd het nodig geacht de keuze van vaardigheden te heroverwegen. Goldstein heeft een groot aantal vaardigheden aangereikt zonder de herkomst ervan op enigerlei wijze te onderbowwen of te verantwoorden (Golasteln c.5., 1976; Goldsteln 0.s., 1980). Niet alleen vertonen deze vaaxdigheden bij eerste inspectie veel overlap met elkaar, ook werd het antal onwerkbar groot geacht.

Goldsteln (1973) stelt terecht dat ex qua principes weinig aan zijn methode nieuw 1.3 , max dat hij wel zeer systematisch een groot aantal verworven inzichten en bestaande procedures heeft geinventariseerd, geintegreerd, toegepast en geävalueerd. Behoudens de vormgeving aan de therapeutische hulpmiddelen (geluids-modeling-banden, vaardigheden met leexpunten) laat zijn beschrijuing van de 'structured learning therapy' (zie 1.3) de lezer echter bijzonder veel ruimte tot eigen interpretatie. Zijn "manual' heeft meer betrekking op hetgeen zich tijdens de voorberaidingen tot de groepssessies zou moeten afspelen dan op het thexapeutisch handelen zelf.

Behoefte werd dan ook gevoeld aan protocol-ontwikkeling, draaiboeken en scenario's van interventies, temeer omctat de projectgroep zich ten doel stelde dexden terzijnertija te instruerer ontrent toepassingen. Tot slot werd en grondige evaluatie van de vaardigheidstherapieên In hun uiteindelijke toepassing nodig geacht. Daarbij zijn de gedachten niet uitgegaan naar aanvullend 'ingredienten-onderzoek' (is interventie C uitgevoerd volgens scenario 2 effectiever dan volgens scemario 3 ?) doch meer naax de resultaten van de therapleên zoals die in de RIAGG's worden toegepast. Niet alleen de ultvoerders van de vaardigheidstherapleen of de verwijzers van deelnemers doch ook belleidsmakexs binnen en buiten deze instellingen, betalende instanties en het 
publiek mogen meer geinteresseerd worden geacht in de effecten van 'alledaagse' toepassingen dan in onderzoek naar de effectititeit van een vlekkeloos uitgevoerd laboratorium-programina. 
2. THEORETISCHE ONTWIKKEL IWGEN EN HUN CONSEQUENIIES VOOR VAARDIGHEIDSTHERAP LEEN

De hoofdcomponenten van Goldstein"s "structured learning therapy" (zle ook 1.3) zijn modeling, gedragsoefening, bekrachtiging en transfertraining. De drie eerste componenten $21 j n$ door Goldstein opgevoerd vanwege hun speclfleke geschlktheid voor cliënten uit lagere klassen en vanwege hun effectivitelt; de transfextraining is later toegevoegd om de duurzaamheid van gedragsverandering te vergroten (Goldstein, 1973). Elk van de componenten is gebaseerd op leertheoretische en gedragstherapeutische inzichten en principes en is veelvuldig object varu onderzoek geweest. Sterk aan deze componenten verwant zijn therapeutische procedures en begrippen als observational learning (Berger, 1961), vicarious leaming (Decharms en Rosenburg, 1960), behavior rehearsal (Lazarus, 1966) en social learning (Bandura, 1969). Toegepast op het aanleren van intexpersooniljk gedrag en/of het bestrijden van sociale angst spreekt men vooral van sociale vaardigheidstherapieien (Van Son, 1978) en assertiviteltstrainingen (Van Dam en Kratimat, 1979).

De theoriean die in de lateste 25 jaar zijn aangewend ter verklaring van het optreden van inadequaat interpersoonlijk gedrag vormen een afsplegeling van de (theoretsche) ontwikkelingen in de gehele gedragstheraple (Van Son, 1930). Na een korte weergave van die ontwikkelingen worat hiex aansluiting gezocht bij een verklaringmodel van Banduxa en wordt ingegaan op de mogelijke consequenties daarvan voor de methode var Goldstein. 


\subsection{Ontoereikende verklaringsmodelien}

Wolpe (1958, 1973) zag het optreden van imadequat interpersoonlijk gedrag primair als het gevolg van een klassiek geconditioneerde angstrespons. Het individu dat herhaldelijk aversieve ervaringen opdoet in sociale sitwaties zal volgens dit respons-inhibitie-model in toenemende mate met angst reageren op nieuwe confrontaties met sociale situaties; deze angst reduceert de gedragsefficiëntie en leidt tot vermijaingsgedrag, dat op zijn beurt weer nieuwe aversieve faal-erwaringen tot gevolg heeft.

Vanuit dit referentiekader bezien wordt aan een interpersoonlijke vaardigheidstherapie de betekenis toegekend van het leren toepassen van responsen die onverenigbaar zijn met angst: reciproke Inhibitie van sociale angsten door het ultvoeren van assertief gedrag in sociale situaties.

Dit model is ontoereikend genoemd, omdat het niet verklaart warom individuen reeksen aversieve ervaringen zouden opdoen in socialle situaties. Bovendien blifken angstbeheersingsprocedures als systanatische desensitisatie niet altijd effectief (Marzililer, Lambert en Kellett, 1976).

Een alternatief biedt het zogenaamde vaardigheids-deficientie-model (Curran, 1979). In dit model wordt ervan uitgregaan dat er individuele verschillen bestaan in repertolres van interpersoonlijke responsen. Ienand met een gebrekkig (a.1. noolt geleerd of in onbrudk geraakt) repertoixe kan aversieve exvaringen opdoen en dabidoor sociaal-angstig. worden.

De behandeling dient vanuit deze optiek dan ook vooral gexicht te zijn op het aanleren van in sociale situaties effectieve interpersoonlijke responsen via modeling en gedragsoefeningen. Eenmal opgenomen in het gearagsrepertoire zullen deze responsen onderhouden worden door succeservaringen.

Dok dit model is ontoereikend. Het verklaart niet het uitblijven van adequaat gedrag bij mensen die beschikken over een adequat gedrags- 
repertolre (Twentyman en Zimmering, 1979).

Belde voorgaande modellen, die met elkar gemeen hebben dat ze gedrag bestuderen als functie van de situatie (antecerente en consequente Btimuli) geven ook geen verkliaring voor modelingmeffecten. Mensen Leren via observatie van gedrag wan anderen (Bandura, 1969). Dit heeft geleid tot veronderstellingen dat individuen responsinformatie coderen en onthouden, warblj het (latere) gedrag zou worden uitgevoerd op geleide van een symbolische (xe-) constructie van het gearag (sociale leertheorie).

\subsection{Het cognitlef sociaal-leertheoretisch model}

Het sociaal-leertheoretisich model, waarin de persoon wordt opgevat als een informatie-verwerkend systeem, is inmiddels verder uitgebreid onder invloed van de cognitieve stroming in de gedragstherapie (Beck, 1976; Meichenbaum, 1977; Ellis, 1979).

Cognitieve factoren, interne dialogen, attributies en verwachtingen worden in toenemende mate verantwoordelijk gesteld voor gedragsproblemen. In het vigerende cognitief sociadi-leertheoretisch model (o.a. Bandura, 1977: Mischel, 1973) wordt gedrag opgevat als resultante van een wederzijase beInvloeding van persoon en situatie (Hettema, 1982):

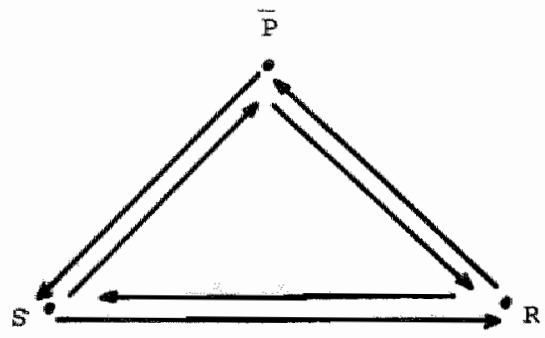

Ex voltrekken zich leerprocessen als de persoon gedragsalternatieven observeert bif anderen en exvaart wat de gevolgen van eigen en andermans gedrag zijn in bepalde situaties $(S \rightarrow P)$, terwjl situaties op hun beurt gedefinieerd worden door de persoon op grond van diens 'cognitieve stricture $(P \rightarrow S)$. 
Gedrag is zowel een functie van de situatie $(S \rightarrow R)$ als van de persoon met zijn intenties en gedragsmogelijkheden $(P \rightarrow R)$. Wet feltelijke gedrag, te onderschelden van het bedoelcle gedrag, leidt tot een (al of niet beoogde) verandering van de situatie $(R+S)$ en leidt tot bevestiging of bijsturing van de cognities betreffende de eigen competentie $(R+P)$.

Het leren via responsconsequenties wordt in dit model gezien als een bijzondere vorm van observatie-leren: men ervaart differentiele effecten van eigen gedrag en vergaart aldus informatie ontrent welk gedrag in welke situatie bepaalde consequenties met zich meebrengt. Wiet de feitelijke consequenties, doch de door het individu verwachte consequenties bepalen het optreden van gedrag (Estes, 1972). ook worat gedrag niet langer opgevat als staande onder stlimuluscontrole $(S \rightarrow \mathbb{R})$ : aan stimuli worden door het individu betekenissen toegekend, warbij riet alleen processen van (selectieve) attentie en waarnening "maar. ook van betekenistoekenning (herkenning, evaluatie) een rol spelen. Stimuli beInvloeden gedrag voor zovex ze voor het individu een voorspellende functie hebben met betrekking tot de warschijnlijkheld dat bepaald gedrag bepaalde effecten zall opleveren.

Het cognitief sociaal-leertheoretisch model maakt inzichtelijk waarom systematische desensitisatie niet altijd effectief is bij de behandeling yan hoog-sociaal-angstigen en verklaart ook waarom het beschikken over een adequat interpersoonlijk gedragsrepertoire geen garantie inhoudt woor het daadwerkelijk gebruik daarvan. Attributles, etiketteringen, interpretaties van situaties en verwachtingen van elgen mogelijkheden sturen het gedrag. In deze 'cognities' zljn het product van (vaak foutieve of irratlonele) denkoperaties, cognitieve schemata en onderliggende, voorbewuste cognities. Zo hebben Schwartz en Gottman (1976) aangetoond dat minder-assertieve mensen neer negatleve en minder positieve 'zelf-beweringen' gebruiken in interne dialogen in interpersoonlijke situatles dan meer-assertieven. Hoog-sociaal-angstige mensen blijken (dezelfae) feedback bovendien als negatiever te interpreteren dan laag-sociaal-angstigen (Smith en Sarason, 1975; Halford en Foddy, 1982). Het belang van zelf-evaluaties blijkt uit de bevindingen dat hoog-sociaal-angstigen in vergelijking 
tot laag-gocladi-angatigen de kwaliteit van hun interpersoonlijke verrichtingen onderschatten (Clarke en Axkowitz, 1975) en

negatieve informatie daarover beter onthouden dan positieve (0*Banion en Arkowitz, 1977).

Een gedgend gedragsxepertoire is kennelijk geen voldoende voorwarde woor het toepassen wan adequat interpersoonlijk gedrag. Het individu zal daarnaast overtugd moeten zijn in staat te zijn tot adequate ultwoering van dat gedrag. Programm's gericht op verandering van Interpersoonlifk gedrag dienen dan ook tevens gericht te zijn op de ontwikkeiling van aciequate/realistische zelfbeweringen en zelfevaluaties.

\subsection{Bandura" self-efficacy theorie}

Bandura"s "self-efflcacy"-theorie kent een centrale rol toe aan zelfbeweringen (Bandura, 1977). Verwachtingen van persoonlijke effectiviteit zouden bepalend aljn voor de keuze voox coping- of vermijaingsgedrag, alsook voor de mate warin coping-gedrag wordt volgehouden In problematische situaties en na aversieve ervaringen. Alle gedragsveranderingen worden gereallseerd door wijzigingen in niveau en sterkte van deze verwachtingen. Deze 'self-efficacy' wordt door Bandura na-

arukkelijk onderscheiden van "response-outcome-expectations" ; terwijl een uitkomst-verwachting betrekking heeft op de persoonlijke schatting dat een bepaalde gedragswijze zal leiden tot bepaalde effecten, heeft de self-efficacy betrekking op de overtuiging zelf in statt te zijn tot succegwolle ultwoering wan (dat) gedrag (Bandura, 1979). Mensen wrezen en vermijden situaties waarvan zif aanemen dat die hun vaardigheden te boven gaan; als zij menen situaties aan te kunnen, gedragen zij zloh ook daarnaax.

Verwachtingen van persoonlijke effectivitelt variëren in hoogte, specificltelt, sterkte en zijn gebaseerd op viex informatiebronnen, te weten:

a. daadwerkelijk gebleken bekwamheid (performance accomplishments)

b. vicarieuze ervaringen 


\section{c. verbale beinwloeding}

d. fysiologische gewarwordingen.

Van deze vier informatiebronnen is de eerste de meest invloedrljke. Terwijl fysiologische gewaarwordingen door het individu voornamelijk beoordeeld worden op basis van betekenistoekenning aan de exterme omstandigheden, verbale beinvloeding sterk afhankelijk is van de geloofwaardigheid van degene aie tracht te overtuigen en vicarieuze ervaringen ongedaan gemaakt kunnen worden door aan modellen speclalle deskundigheid toe te schrijven, is de kwalitelt van gedragsuitvoering door het individu zelf het minst afhankelijk van dit soort cognitieve 'appraisals'. Bandura draagt een groot aantal empirische argumenten aan on de superioriteit van de "pexformance-based" procedures (zoals desensitisatie in vivo, massive exposure, participant modeling) over de 'symbolically based" behandelingen (cesensitisatie in vitro, imagined exposure, vicarieus leren, verbale methoden, etc.) te onderstrepen. Toch ziet hij voor de verbale methoden nog een rol weggelegd in gedragsvexanderingprogramma 's:

"People who are socially persuaded that they possess the capabilities to master difficult situations and are provided with aids for effective action are likely to mobilize greater effort than those who receive only the performance aids".

Met zijn self-efficacy-theorie verzoent Bandura twee zaken die ogenschijnlijk halaks op elkaar staan:

a. het feit dat performance-based procedures bij voortaring effectiever blijken dan symbolically based ervaringen in het bewerkstelligen van psychologische veranderingen.

b. het groelende en steeds meex verbreide inzicht dat de mechanismen die verwerving en regulatie van menselijk gedrag vexklaren van cognitleve aara zijn.

Door te postuleren dat verwachtingen van eigen competenties in specifieke sitwatles uiteindelijk bepalend zijn voor therapeutisohe verandering, terwijl deze verwachtingen gebaseerd zijn op informatie die op de eerste plaats geput wordt uit elgen perfomance-ervaringen, maakt hij inzichtelijk dat (cognitieve) verandering het best gexealiseera kan worden via performance-based procedures. Het nastreven van verandering van cognities impliceert dus geenszins het aanwenden van 
'cognitieve methoden". Eripirische data ondersteunen Bandura"s *tellungrame dat generaliserende en blijvende veranderingen wan effectiviteitswerwachtingen en van gedrag het best gerealiseerd kunnem morden by partlcipant methods using powerful induction procedures initially to develop capablilties, then removing external alds to verify personal efflcacy, then finally using self-directed mastery to strengther and generalize expectations of personal efficacy" (Bandura, Jeffery and Gajdos, 1975; Bandura, 1977). Bandura heeft diverse studies ultgevoera on de self-efflcacy-theorie te toetsen blj foblci (Banduza, Adams en Beyer, 1977; Banduxa, Adams, Hardy en Howells, 1980). Zijn hypothesen dat "mastery-experiencestreatment' tot grotere verandering van de self-efficacy leidt dan 'vicaxleuze behandeling' en dat self-efficacy-uitspraken zeer nauw gerelateerd zijn aan daadwerkelijk gedrag werden daarbij bevestigd. ook Biran en Wilson (1981) rapporteren soortgelijke bevindingen: performance-based behandeling blijkt superieur aan cognitieve herstructurering, terwijl gedragmaten en self-efficacy-ratings hoog correleren.

\subsection{Conseguenties voor Goldstein"s "structured learning thexapy"}

Goldstein ontwikkelde zijn 'structured learning therapy' in een periode warin zelfbeweringen en, meer algemeen, cognities nog niet de rol werden toebedacht als nu het geval is. Hil selecteerde zijn technieken op geschiktheid voor de doelgroep en trachtte in de vormgeving aan procedures recht te doen an empirische bevindingen die de effectivitelt betrefter.

De vraag is In hoeverre de door Goldsteln ontwikkelde vaardigheidstherapieen bijstelling of aanvuling behoeven om recht te doen aan het cognitief social-1eextheoretisch model en de daaruit af te leiden inaichten.

De 'structured learning therapy' (zie 1.3) is bij uitstek performancebased. Modeling en aanvankelijke gedragsoefeningen vormen het inductieprogramma, warna werwachtingen van eigen effectiviteit verder kunnen 
worden gevormd en getoetst via voortgezette gedragsoefening leigen versies, elgen situaties, etc., zie 1.3.2) "bekrachtiging en "hulswerk". De structured learning therapy behoet geen bijsteling of witbrelding op grond van de theoretische ontwikkelingen. Wel ls het mogelljk met behulp van recente theoretische inzichten de effectiviteits-verhogende werking van diverse procedure-attributen te verklaren.

zo bevatten Goldstein"s modeling-banden niet alleen respons-informatie, doch orik

- informatie over de effectiviteit van een respons, ex

- informatie relevant voor de verwachting van de elgen effectiviteit van de observator.

Respons-informatie wordt verschaft door een deskundige (geloofwaaraig) die beweert dat het om relevante informatie gaat en die leerpunten noent, die enerzijds de attentie sturen bij het aanhoren van de hoorspelen, anderzijds een bemiddelende rol vervulien bij de codering, opslag en (latere) symbolische reconstructie van de geboden gedragsinformatie en tevens door een aantal gedragsmodellen die tonen hoe, en ook hoe verschillend, de betreffende respons(klasse) vorm kan krijgen. Informatie over de effectiviteit van een respons wordt aangexelkt door de deskundige, die wijst op de voordelen van toepassing van de vaardigheid en op mogelijke aversieve consequenties van het achterwege blijven van de betreffende interpersoonlijke activiteit in diverse situaties, en via de hoorspelen waarin toepassing van de vaardigheld steeds tot beocgde effecten leidt.

Informatie, relevant voor de verwachting van eigen competentie (selfefficacy), wordt wederom gegeven door de deskundige, die beweert dat men (dus iedereen, dus ik ook) deze vaardigheid kan lexen, door meerdere modellen (als die dat allenaal kunnen, kan 1 k dat ook), door meerdere modelgedragingen, die in hun onderscheidenheid informatie bevatten omtrent tolerantle voor afwijkingen van een denkbare standaard (iedereen doet het op zijn manier, mijn maniex zal ook goed zijn) met een gerede kans dat men een model of een modelgedrag tegenkont, warvan men op grond van gelijkenis kan aannemen: 'als die dat kan, kan $\mathfrak{i k}$ dat ook' of 'zoals die het doet, kan ik het ook' (Bandura, 1977; Rosenthal. en Bandura, 1978).

Gedragsoefeningen scheppen de gelegenheid on aan de hand van observeer- 
bare discrepanties tussen de aangeboden gedraginformatie en de als reproductie daaryan bedoelde overte responsen aanvuliende en corrigerende Informatie aan clienten aan te reiken. Zij fungeren echtex tevens als informatiebron voor uitkomst-effectiviteit, doch vooral als Informatiebron roox seli-efficacy.

Het geloof in elgen competentie kan aanvankeIijk beperkt zijn tot discrete responselementen, wat aanleiding geeft tot imitaties van haalbare delen van de geboden responsinformatie. Bekrachtiging, zelfobservatie en verbale suggestle door de therapeut versterken de selfefficacy en darmee de verwachting ook aan volgende opdrachten te kumner voldoen. Zo zal de cliënt in toenemende mate bereid en in stat blijken in meer elgen versies, onder gevaxieerde en moeilijker onstandigheden en ondex terugtrekking varn hulp laamoediging, gedxagsinstructies, e.a.) de vaaralgheid gestalte te geven.

ook de bekrachtiging kont met de self-efficacy-theorie in een nieuw licht te stan. De tendens bij vele clienten on hun eigen verrichtingen te onderschatten (zie 2.2) wordt gecorrigeerd door het stelselmatig prijzen (door therapeut en mede-cliënten) van adequate responsen. Voor zover dit op geloofwardige wijze gebeurt, zal de cluent deze informatie verwerken tot een positiever en realistischer verwachting ten aanzien van eigen gedragsmogelijkheden.

Elementen van transfertraining, die grotendeels hun beslag krijgen in modeling, gedragsoefening en bekrachtiging (zie 1.3.4), kunnen eveneens herleid worden tot matregelen die bijaragen tot de ontwikkeling van een hoger, stexkex en meer gegeneraliseerd niveau van verwachting van elgen competentie.

Howel. succeservaringen het middel bij uitstek zijn om de self-efficacy te ontwlkkelen en daardoor gedragsverandering te bereiken, oreerren succeservaringen niet noodzakelijkerwijs sterke en gegeneraliseerde verwachtingen van persoonlijke competentie. Banduxa (1977) wijst erop dat zolang mensen consequenties van gedrag kunnen toeschrijven aan velilge of geisakkelijke omstandigheden, de verxichtingen zelf kunnen toeschrijven aan de hulp die daamee geparar ging, of aan de grote inspanningen die zij zich daarvoor moeten getroosten, deze ervaringen nawwelijks zulien bijdragen aan een groel van de verwachting van eigen 
competentie. De wijze waarop succeservaringen cognitief worden verwerkt is van groot belang.

In de vormgeving aan de interpersoonlijke vaardigheldstherapièn zullen matregelen ingebouwd dienen te worden die foutieve verwerkingen kunnen voorkomen en corrigeren. 
3. DE KEUZE WAN IMTERPERSOONLIJKE VAARDIGHEDEN *

Dit hoofdstuk behandelt een studie die is uitgevoexd om tot een verantwoorde keuze te komen van interpersoonlijke vaardigheden, op te nemen in het pakket vaardigheldstherapieen. In eerste instantie wordt. getracht op grond wan literatuurstudie het uitgebreide domein van Interpersoonlijke gedragswijzen te reduceren tot een overzichtelijk geheel. Vervolgens wordt een onderzoek beschreven dat is ultgevoerd onder cliënten on meer zicht te krijgen op de intexpersoonlijke gedragsproblemen in de doelgroep.

Dat de te operationaliseren vaardigheidsthexapieën onder meer dienden te voorzlen in de mogelijkheid Interpersoonlijke vaardigheden te verwerven, was van aarvang af een vaststaand gegeven. Het belang van een effectief intexpersoonlijk gedragsrepertoire voor de geestelijke gezondheid wordt alom erkend (o.a. Sullivan, 1953. Phllips, 1978). Gebrek aain interpersoonlilyke vaardigheden speelt niet alleen een rol in problemen als afhankelijkheid, soclale isolatie, anti-sociaal agressief gedrag en huwelijksproblemen, maar ook in depressies, sexuele dysfuncties, fobleen, verslavingen, psychosomatische klachten en dergelijke (Gambril1, 1977; Walburg, 1980; Varn Son, 1980).

ook Goldstein is deze overtuiging toegedaan. Hij presenteerde aanvankelijk 22 "conversatie-vaardigheden. naast 8 "altematieven voor agressie', 7 'planning-vaardigheden' en 22 'toegepaste' vaardigheden (Goldstein c.s.,

over dit onderwerp is eerder gepubliceerd door Beekers en Haifens (1981). 
1976). Later (Goldstein, Sprafkin, Gershaw en Klein, 1980) Rin daar een aantal vaardigheden en vaaraigheiascategorieen aan toegevoega. Inhoudelijk bezien lijken somige vaardigheden elkaar te ovexlappen, andere (bijvoorbeeld 'starting a conversation', "continuIng conversation' en 'ending a conversation'y zifn dermate 'moleculair" dat ze slechts zinvol inzetbaar zijn als onderdeel van een vaardighedenpakket. De vraag dringt zich op of ex een zinvolle (her) sichlkking van interpersoonlijke responsen c.q. responsklassen mogelijk is, zodanig dat

(a) elke interpersoonlijke vaardigheid wezenlijk te onderscheiden is van de andere,

(b) elke vaardigheid een voldoende molaix karakter heeft c.q. als solo-pakket zinvol kan worden aangeboden,

(c) het aantal vaardigheden wordt teruggebracht, waardoor aan verwijzers een overzichtelijk aanbod kar worden gedaan en snelle doorstroming van verwezen clienten mogelijk wordt,

(d) het vaardigheden-aanbod recht doet aan de "vraag" (gedragstekorten en -excessen) van de doelgroep.

\subsection{Op zoek naax een referentiekader}

Kan het brede scala interpersoonlijke gedragıngen/gedragswijzen teruggebracht worden tot een klein overzichtelijk aantal op zodanige wijze dat wezenlijke eisen/dilemma's van interpersoonlijke aard de inhoud ervan bepalen?

Het antwoord op die vraag is niet te vinden bis auteurs op het terrein van sociale vaardigheldstherapie en assertiviteitstrainingen co.a. Gambri11, 1977; Schouten, 1977, Van Son, 1978; Van Dam-Baggen en Kraaimaat, 1979), ook al doen zij allen wel, min of meex tentatief, suggesties betreffende het belang van bepaalde interpersoonlijke thema"s en responsen.

In andere kaders is wêl gezocht naar een functioneel systeem van klassen van intexpersoonlijk gedrag, dat het potentiële aantal gedragswijzen terugbrengt tot een werkbare reeks en tevens voldoende ult- 
puttend is on nagenoeg elke voorkomende interpersoonlijke gedragswize onderdak te kunten bleden, inclustef 'abnormale' gedragsujjen.

\subsubsection{Hoofddituensies en Interpersoonlijk gedrag}

Brown (1965) heeft een zorgnildige en uitvoerige conceptuele analyse uttgevord van de formele kenmerken van menselijke interacties en komt tot de conclusie dat twee dimensies daarin praktisch universeel zljn: "status" en 'solidariteit". Carson (1969) geeft een overzicht van een antal empirische studies waxin gedragingen worden geobserveerd an "geturfa" en waarin mensen elkadx beoordelen in een wisselend aantal. categoriern. Factor-analyses leiden in al deze studies tot twee of meer factoren, warbij Brown's dimensies steeds bevestigd worden. De status-dimensfe van Brown wordt nu eens aangeduld als 'individuele prominentie" "dan weer als 'assertiviteit', 'macht' 'extraversie', 'strenghela" of "dominantie"; de "solidariteitsaimensie" komt terug als "socibildteit", "vriendelijkheid", 'liefde" "affiliatie" of "warmte" " Plaatsen we beide onafhankelijke dinensies als coordinaten in een hypothetische twee-dimensionall vlak (figuur 3.1), dan ontstaan 4 quadranten waarvan de inhouden kwalltatief onderscheidbare vormen van sociaal gedrag representeren.

Flguar 3.1

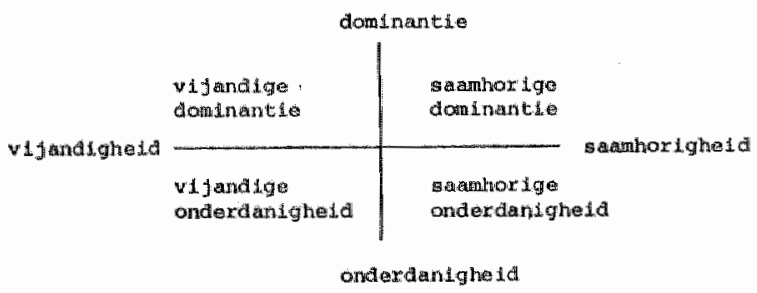

Wen interessant kenmerk van dit model is dat het de mogelijkheid biedt on nast $\mathrm{kwaliteiten} \mathrm{ook} \mathrm{intensiteiten} \mathrm{van} \mathrm{gedrag} \mathrm{weer} \mathrm{te} \mathrm{geven:} \mathrm{met} \mathrm{een}$ punt in de ruimte, rekenend vanuit het neutrale centrum, kan aangegeven worden dat een gledragswijze bijvoorbeeld is te typeren met 5 eenheden dominantie en 2 eemheden vijandigheid. 
Het model biedt bovendien mogelijkheden recht te doen aan bevinaingen die een circulaire ordening van intexpersoonlijke gedragingen suggereren, in die zin dat gedragswijzen ten opzichte van elkaar geordend kunnen worden op grond van hum onderlinge intercorrelaties in een systeen dat geen begin- of elndpunt heeft.

Grondlegger van dit model is Leary (1957) die de ruimte verder opdeelt in 8 'octanten' en onderscheld makt tussen 3 intensiteits-niveau's: (1) een milde, minimaal noodzakelijke, (2) en gematigde, passende en (3) een sterke ongepaste hoeveelheid, in figuur 3.2 weexgegeven in respektievelijk een binren-, een midder- en een buitencirkel.

Figuur 3.2

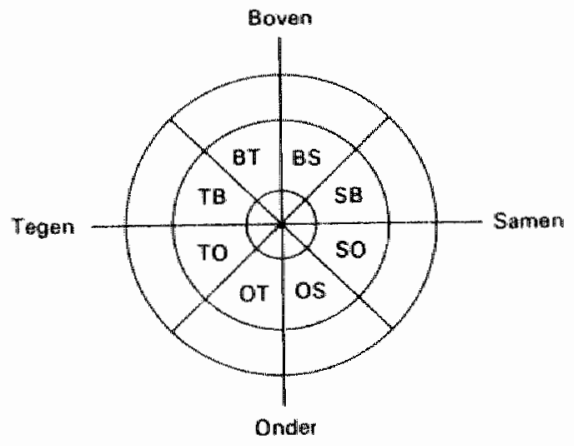

\footnotetext{
De outant - wasiabelien kumen ofmethreven wondien alsi

S. Samen-Bewen: Verantwoordolijk helpenat godrag

SD: Sanen-Onder; Cooperatiel, famleumend.

OS: Onder-Samem: Antankellik. wolgend

OT: Onder -Tegen: Terupgetrokhion, verlegen.

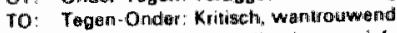

TB. Togen-Boven: Aanwulland, agosist

BY: Boven. Togen: Competilial. onafhamkefijlk

S: Bover-Semen: Lewdeind, beinvioedend
}

Leary gaat ervan uit dat elk van deze intexpersoonilike gedragiswijzen op niveau 2 in en 'gezond' gearagsrepertolse thushoort. zowel het nilet beschikken over een minimum als het overschrijden van een bovengrens, per octant, zou als inadequat of pathologisch te beschouwen zijn. 


\subsubsection{Leary'e roos en de ICL}

Het model van Leary, bekend als de "roos" van Leary, wordt bevestigd door diverse empirische studies. Zo bevestigen Schaefer (1959), Foa (1961) en Lorr en MoNalr (1963) de circulaire ordening in het domein van interpersoonlijke gedragswijzen.

LaForge en Suctek (1955) presenteren de 'Interpersonal Check List" (ICL), bestaande uLt 128 korte uitspraken over interpersoonlijk grearag: per (Leary-loctant 16 uitspraken, die verschilien in intensiteit. Dit instrument worat toegepast om overt gedrag (hif is/kan ....), zelfbeld (ik ben/kan ....) en warden (ik zou willen ....) van interpersoonlijke aard te meten. actantscores worden doorgaans vastgesteld door sommatie van het aantal "ja"-antwoorden per subschal (maximumscore 16).

Test-hertest-correlaties tussen .73 en .83 pex octant bij zelfbeschxifvingen van vrouwelijke obesitas-patiennten bevestigen de stabilite 1t van het instrument, terwijl interoctant-correlaties inderdaad afnemen naarmate de afstand tussen octanten in de roos toeneemt (LaForge en Suczek, 1955). Armstrong (1958) laat 50 alcoholici en 50 'normalen' zichzelf, hun moeder, hun vader, hun vrouw, mun ideale vrouw en hun Laeale-zelf beschrijven met behulp van de ICL en vindt interne (KudexRichardson) betrouwbaarheden die allen boven de .95 liggen.

De ICL is in het Nederlands vextaald doox Dlekstra (1972) met het oog op een cross-culturele structurele validatie van de ICL. Vergelijkingen tussen Nederlandse en Amerikaanse factor-patronen in beschrijvingen op de IcL leveren 'hast perfecte structurele overeenkomaten" op (Dlekstra en Truckermillex, 1977 ).

De ICL-studies hebben echtex slechts gedeeltelijke bevestiging van Leary's model opgeleverd. Doorgaans worden bij factor-analyses over octantscores op de niveau's van beoordelingen-door-anderen en van zelibeschrjuingen 3 in platas van 2 dimensies (factoreml gevonclen. Twee van de arie hebben steeds grote gelijkenis met de Liefde-versus-Haat en Doninantie-versus-Submissie dimensies. De derde factor, gekenmerkt door hoge ladingen van de OT- en OS-octantscores, wordt vaak aangeduld als 'minderwardigheldsgevoelens' (Briar en Bieri, 1963; Truckermilier, 
1971; Diekstra en Truckenmiller, 1977) of als 'passiviteit" (Knippenberg, 1979$)$.

Is er werkelijk een derde dimensie in het spel? Als we te rade gaan bij studies, anders dan met behulp van de ICL, dan noemt Carter (1954) in een overzicht wan factor-analytische studies van interpersoonlijk gedrag in kleine groepen naast 'prominentie" en 'sociabilitelt' een factor 'taak-inzet' .

Borgatta (1960, 1964) windt naast assertiviteit en sociabiliteit factorem die hij interpreteert als 'manifeste intelijgentie', "manifeste enotionaliteit' en 'taak-interesse'.

Schutz (1966) gat uit van 3 dimensies: macht, affectie en meetelien (erbij horen). Klassieke theorleen op het gebied van sociale motivatie maken vaak onderscheid tussen machts-, afflliatie en prestatienotivatie (Atkinson, 1963).

De twee Leary-dimensies komen steeds terug, de araran een eventuele derde dimensie blijft onduidelijk. Soms lijkt deze betrekking te hebben op een situationele factor (b.v. taak-inzet), soms op een dimensie die gedragingen onvat die weliswaar interpersoonlijk te beschrijven aijn, doch feitelijk voortkomen uit intenties van niet-interpersoonlijke aard (taak-inzet, onafhankelijkheid, manifeste intelligentie, passiviteit).

Osgood, Sucl en Tannenbaum (1957) die de basale dimensies van betekenistoekenning aan objecten (inclusief personen) trachten te identificeren, vinden arie onafhankelijke factoren: een waarde-, een potentie- en een activiteitsfactor (resp. goed-slecht, sterk-zwak en actief-passief). TaIrijke latere onderzoekingen, ook hier ten lande (o.a. Kouwer, 1958 en 1961; Bremer, 1972; Groenman, 1978) waarin Osgood's contrastprofielenmethode is toegepast, bevestigen deze grondalmensies in de menselijke betekenisruimte. Toegepast op de beoordeling van interpersoonlijk gedrag kan men stellen dat Osgood"s eerste twe factoren terugkomen in Leary's liefde-haat en domlnantie-submissie dimensies, terwijl de activiteitsdimensie niet opgenomen is in Leary's mode1, doch wel wordt aangetroffen bij factor-analyses van ICL-scores: de als "minderwaardigheidsgevoelens' of 'passiviteit' benoemde factoren. Cuveliex (1976, 1977) makt wan Leary's cirkel weliswaar geen bol, maar verwerkt die activiteitsdimensies in zijn topologie van interactiewijzen door het 
postuleren van een passieve bovenpositic ("houden') en een passieve onderpositie ("Lossen") naast die actleve posities van 'geven, nemen, kilatwen en weerstaan'.

\subsection{ICL-afname bij cliënten}

Het boven beschrevene levert een eerste houvast voor een verantwoorde reductie van het grote antal potentiële interpersoonlijke vaardigheden. We hebben echtex tevens te maken met een specifieke doelgroep: cliënten uit de lagere sociaal-economische klassen (Libo-cliënten). De vraag die zich opdringt is: zijn er interpersoonlijke gedragswifzen, posities in Leary's roos, die voor de Libo-doelgroep meer problematisch $z i j n$ dan andere? Natururlijk heeft elk individu een unjek interpersoonlijjk gedragsrepertoire, favoriete rollen waar hij graag zijn toevlucht in zoekt en interpersoonlijke posities die hij blj voorkeur vexmijdt of zelfs in het geheel niet in kan nemen. Dat geldt ook voor Libo-clienten. Zouden dezen echter als groep gekenmerkt worden door markante "tekorten' en/of 'excessen" in bepaalde interpersoonlijke gedragswijzen, dan zou een voor deze doelgroep bestende serie vaardigheden daax op dienen te zijn afgestema.

De Iurck (1978) noemt sociale klasse een van de belangrijkste, zo niet de belangrijkste, factor in het ontstaan van psychische stoornissen. Gielss. Seidel en Abholz (1973) benadrukken sterk de invloed van het social-economisch milleu op het ontstaan van gedragspatronen. Kohn (1969) toont aan dat ouders uit de werkende klasse in hun opvoeding mëer conformitelt ten alanzien van extern gezag opleggen aan hun kinderen, dan ouders uit de middenklasse die meer nadruk leggen op zelfcontrole. Lunaberg (1974) stelt dat middenklasse-ouders meer behulpzaam, empathisch en tolexant zijn dan ouders uit lagere klassen. Daartegenover stellen Miller en Riesman (1969) dat het streven naar stabiliteit en veiligheid een der belangrijkste kenmerken is van het axbeidersleven, en dat cosperatie en wederzijase hulp belangrijke mechanismen zijn in dit streven. Poglngen on uit de literatuur meer houvast te krijgen ten aarzien van de typische interpersoonlijke ver- 
wachtingen, eisen en noden in de doelgroep strandaen.

De meeste bevindingen hebben immers betrekking op Amerikaanse populaties. Verder maken de onderzoekers vaak een verschil tussen subklassen van 'arbeiders' en 'armen' (Hollingshead en Realich, 1958), 'stabielen' en. 'instabielen' (Rubin, 1976), die naar waarden en gedrag nogal verschillen, terwijl wij in feite ëen (tibo-Mgroep voor ogen hebben. Bowendien bestat onze doelgroep uit clienten, dat wil zeggen uit een selectie uit de groep potentiele cliënten, die weer een subgroep vormt uit de Libo-populatie.

\subsection{1 onderzoeksopzet}

Besloten is een steekproef zuldimburgse clienten zichzelf te laten beschrijven op de ICL, om op basis daarvan een beeld te krijgen van door hen zelf ervaren tekorten en excessen in het interpersoon lijk domein. Leary noent octantscores van 15 of meer en van 2 of mindex 'pathollogisch'; uit zijn beschrijving blijken hem daarbiji extremen voor ogen te staan die men in de ambulante zorg nauwelijks zal aantreffen. Ondat ook minder extremen baat plegen te vinden bij sociale vaardigheidstherapieern is, enigszins arbitrair, besloten scores van 4 of mindex als gedragstekort en van 13 of meer als gedragsexces te definieren.

Aangezien de constructeurs van de ICL slechts met de grootste moelte slaagden in het vinden van geëlgende omschrijvingen van gedrag in de diverse subgebieden meent Carson (1969) dat men bij toepassingen van de ICI alert moet blijven op hieruit voortkomende vertekeningen.

Deze overweging geldt zekex bjJ afname van de ICL onder Limburgse Libo-clienten (taalgebruik). Vandaar dat na af name van de lijst bepaling van de interne consistentie van de diverse subschalen geboden is. Intercorrelaties tussen en factor-analyses over octantscores zullen verder bevestiging moten geven van de mate waarin Leary's model op de doe 1 groep van toepassing is.

De te ontwikkelen sociale vaardighelastheraple en zifn primaix bedoeld woor volwassen cliernten wan de curatieve sector van de ambulante GGz in Zuid-Limburg, afkomstig uit de lagere sociaal-economische klassen. 
Dok clituten uit de hogere milielis worden echter in het onderzoek betrolken on een meer geprofileerd beeld te krijgen van de doelgroep. Van de 3 instellingen voor ambulante geestelljke gezondheldszorg in zuidLimburg is de grootste (RIAGG-Maastricht) benaderd en bereid gevonden on an het onderzok mee te werken. De onderzolekspopulatie is gedeflnieerd als alle clienten van het RIAGG-Maastricht, in behandeling op het moment van dataverzameling, voor zover niet jonger dan 18 jaar of ouder dan 65 jaar.

Er is een a-selecte steekproef getrokken uit het geregistreerde cliëntenbestand; de ICL Ls ter invulling aangeboden aan 278 clienten.

\section{2 .2 Respondenter}

156 vragenlijsten zijn bruikbaax ingevuld geretowrneerd (56\% van de 278 ultgerelkte lijsten).

Tex controle op de representativiteit zijn enerzijds de respondenten vergeleken met het totale (volmassen) clientenbestand, anderzijds de Libo-respondenten met de Libo-cliënten. Daaruit blijkt dat de respondenten woor wat betreft sexe, burgerlijke staat en leeftija als representatief voor de onderzoekspopulatie kunnen worden beschouwd. Ook de 94 'Libo'-respondenten blijken op deze kenmerken representatief voor de Libo-cliêntenpopulatie. Dit betekent natuurlijk niet dat de respondenten ook representatief zijn voor de doelgroep voor wat betreft interpersoonlijke gredragskenuerken (conformisme, wantrouwen, e.d.).

Lager Inkomen, Beroepsprestige en Opleidingsniveau (IIBO) zijn als wolgt geoperationaliseerd:

- Lager Inkomen

- Lager Beroepsprestige

- Lager opleidinganiveau.
: Verplicht verzekerd via ziekenfonds.

: de eerste 4 categorieen van de Beroepenindeling van het ITS (Westerlaak, Kropran en Collaris, 1975 ).

: maximaal MULO/MAVO of 3 jaar vervolgonderwijs. 


\subsection{Controle van de Interpersonal Checklist}

On eerdergenoemde reden (zie 3.2 .1$)$ is de interne samenhang van de 8 subschalen nader bekeken, zijn de intercorrelaties tussen de subschalen berekend en is een factor-analyse uitgevoerd over de actantscores.

\subsubsection{De_interne consistenties}

De interne consistenties van de 8 subschalen zlin vermeld in tabel 3.1. Geconstateerd mot worden dat 4 van de 8 schalen een alphabetrouwbaarheid beneden de .70 vertonen, hetgeen ongunstig afsteekt bij de bevindingen van Knippenberg (1978) die thuislozen laat beschrijven door beoordelaars.

Tabel 3.1 Interne consistentie (alpha) van de 9 subschalem

\begin{tabular}{lcccccccc}
\hline Varliabelen & BS & ET & TH & TO & OT & OS & S0 & SB \\
\hline $\begin{array}{l}\text { Elgen onderzoek } \\
(N=156)\end{array}$ & .78 & .68 & .53 & .63 & .74 & .65 & .75 & .76 \\
$\begin{array}{l}\text { Knlppenberg } \\
(N=539)\end{array}$ & .88 & .86 & .73 & .86 & .60 & .82 & .86 & .88 \\
\hline
\end{tabular}

Vrij laag is met name de interne consistentie van de TB-subschaal. Mogelijk hangt dit samen met een afwijkend Limburgs taallgebruik.

\subsubsection{Relaties tussen de variabelen}

Op grond van de circulalre ordening van de 8 interpersoonlijke varlabelen mag verwacht woxden dat de correlaties tussen de variabelen afnemen naarmate deze verder ult elkaar liggen in Leary's roos. Tabel 3.2 toont de correlatie-matrix van de octantscores, tabel 3.3 de gemiddelde correlaties bij respektievelijk $1,2,3$ en 4 positieafstanden. 


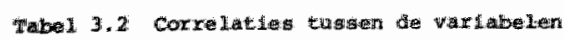

\begin{tabular}{|c|c|c|c|c|c|c|c|c|}
\hline & Bas & $B$ & "IB & mo & $o n$ & os & $\mathrm{SBD}$ & 58 \\
\hline BS & $*$ & & & & & & & \\
\hline$B x$ & .58 & - & & & & & & \\
\hline T & .31 & .32 & - & & & & & \\
\hline To & .09 & .05 & .36 & - & & & & \\
\hline or & -.24 & -.37 & .12 & .23 & - & & & \\
\hline os & .04 & -.15 & .04 & .00 & .55 & - & & \\
\hline 80 & .27 & .16 & -.07 & -.20 & .16 & .43 & - & \\
\hline 5 & .32 & .06 & .07 & -.06 & .22 & 44 & .67 & - \\
\hline
\end{tabular}

Howe 1 tabel 3.2 enkele onregelmatigheden laat zlen in het te vexwachten patroon van intercorrelaties, wordt de clroulaire ordening in grote lijhen bevestiga (zie tabel 3.3).

Tabel 3.3 Gemidelde correlattog tussen varlabelen als functie van hun onderinge afstand in de clakel

\begin{tabular}{rlccc}
\hline & \multicolumn{4}{c}{ Afstand tussen de vartabelen } \\
& 1 & 2 & 3 & 4 \\
\hline Geriddelde correlatie & .43 & .18 & .01 & -.13 \\
\hline
\end{tabular}

\subsubsection{Factor-analyse}

factor-analyse over de scores op de 8 subschalen levert drie factoren op met een elgenwarde grotex dan 1. Deze factoren verklaren tesamen 72.68 van de totale varlantie. In tabel 3.4 is de geroteerde factormatrix weergegeven, tesamen met de eerdere bevindingen in deze van Briax en Bieri (1963), Diekstra en Truckenmilier (1977) en Knippenbexg (1978). 


\begin{tabular}{|c|c|c|c|c|c|c|c|c|c|c|c|c|}
\hline & \multicolumn{2}{|c|}{ Briar en } & Mieri & \multicolumn{2}{|c|}{$\begin{array}{l}\text { Diekstra on } \\
\text { miller }\end{array}$} & \multirow{2}{*}{$\frac{\text { Tracken- }}{\text { III }}$} & \multicolumn{3}{|c|}{ Knippentbary } & Eigien & \multicolumn{2}{|c|}{ ander } \\
\hline & $I$ & $I I$ & $\operatorname{III}$ & $r$ & IH & & $\mathbf{I}$ & $\mathbf{I X}$ & III & $\mathbb{Z} \mathbf{I}$ & $\mathbb{1}$ & XI \\
\hline BS & .70 & .4 & -.07 & .78 & $.2 \mathrm{~g}$ & -.14 & .81 & .41 & -.22 & .71 & $.25^{7}$ & .16 \\
\hline ET & 67 & .22 & -.02 & .72 & .08 & -.49 & .86 & -.04 & -.26 & .74 & .00 & .10 \\
\hline TES & .79 & .05 & .24 & .60 & -.12 & .25 & $.8 B$ & -.11 & -.09 & .37 & .00 & .49 \\
\hline $\mathrm{TO}$ & $.57=$ & $=.03$ & .57 & .47 & -.19 & .73 & .71 & -.60 & .10 & .00 & -.06 & .68 \\
\hline$O T^{*}$ & -.01 & .23 & $.7 B$ & -.33 & .23 & .76 & -.21 & .14 & .89 & -.60 & .49 & .34 \\
\hline os & .13 & ${ }_{n} 5.3$ & .55 & -.10 & .4 & .70 & -13 & .29 &.$a 7$ & -.23 & .6 .7 & .15 \\
\hline so & .25 & .79 & .15 & .02 & .90 & .05 &. .08 & .76 & .55 & .21 & .70 & -.26 \\
\hline $\mathrm{SB}$ & .19 & .71 & .17 & .17 & .86 & .22 & .07 & .89 & .30 & .10 & .75 & -.05 \\
\hline $\begin{array}{l}\text { werklaarde } \\
\text { wariantile }\end{array}$ & .25 & .21 & .17 & .310 & .25 & .17 & .46 & \pm 4 & .27 & .26 & .29 & .10 \\
\hline
\end{tabular}

De in de onderhavige studie gevonden factor I worat kennelijk vooral gedefinieerd door de octanten SB, so en OS, en kan de samhorigheids(S-) factor genoend worden, in Leary's termen de "Love"-factor.

Factor II wordt gekenmerkt door hoge BT en BS ladingen. Het felt dat de oT-variabele een lading van -.60 op deze factor heeft, bevestigt dat we hier te doen hebben met en "cominantie"-factor. De derde factor lijkt een 'vijandigheids'-'T'-factor te zijn. Vergelijken we onze pevinaingen met die van andere oncierzoekers (tabel 3.4) dan walt op dat onze dominantie-factor in tegensteling tot die van de genoemde studies niet door agressiviteit wordt gekenmerkt. Voorts is onze derde factor nitet, zoals bij de overigen, een factor 'minderwaardigheidsgevoelens' (Briar en Bieri, Dlekstra en Truckenmilier) of "passivitedt" (Knippenberg), doch een "tegen'- of "vijandighelas" factor.

Een additionele factor-analyse met 4 factoren levert echter het volgende resultaat op:

- Factor I wordt van zijn submissieve ondertoon (OS, OT) ontalar en proflleert zich nog sterker als "saamorlgheids"-factor.

- factor II handhaaft zich als 'dominantile'-factor, maar nu zonder de hoge negatieve lading van de variabele oT.

- Eactor III is nieuw en kan aangeduid worden als 'passiviteit", 'minderwaardigheldsgevolens', of in de termen van Leary: submissie. 
- factor Ir ls opnleuw, doch duldelijker, een "vijandigheids"-factor. Daarmee zijn we terug bij de 4 polen van de roos van Leary.

Wellicht betekent deze bevinding dat de dimensies van dominantie versus onderdanigheld en liefde versus hat weliswar als bipolaire continua kunnen worden beschreven doch dat, althars in zelfbeschrijvingen, de mate waarin men zich manfesteert naar de ene pool betrekkelijk onafhankelijk kan zijn van de mate warin men dat doet naax de andere zijde van het continuum.

De bevindingen rechtvaardigen een voortzetting van de voorgenomen databewerking; wel zullen resultaten die betrekking hebben op de TBvarlabele met het nodige voorbehoud dienen te worden bezien.

\subsection{Interpersoonlijk gedrag van Libo-cliënten}

\subsubsection{Libo's_versug_niet_Libo's}

Teneinde te bezien of Libo-cliënten zich van niet-Libo-clienten ondexscheiden wat betreft (zelfgerapporteerde) interpersoonlijke gedragswijzen zijn belde groepen vergeleken op ICL-octantscores.

Tabel 3.5 toont de gemiddelde octantscores voor Libo-cliënten naast die van de overige (niet-Libo) elienten.

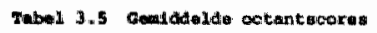

\begin{tabular}{|c|c|c|c|c|}
\hline & 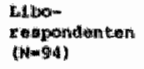 & 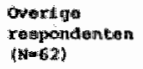 & $\begin{array}{l}\text { 'e- } \\
\text { watartate }\end{array}$ & 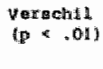 \\
\hline ns & 6.0 & 6.2 & -.29 & Dive \\
\hline 醉 & $5: 0$ & 4.4 & 1,34 & 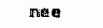 \\
\hline 践 & H. & 7.7 & 1.47 & thete \\
\hline Do & 7.0 & 格, & -1.45 & note \\
\hline$\theta t$ & 9.3 & 9.1 & .31 & mee \\
\hline $\mathrm{css}$ & 4. 3 & 6.2 & -4.49 & 10 \\
\hline 0 & 9.1 & 6 & 4.50 & $\$ \mathbf{a}$ \\
\hline$\sqrt{3}$ & 8.0 & ta..5 & 2.38 & \pm 0 \\
\hline
\end{tabular}

Uit de tabel blijkt dat Libo-cliënten zichzelf in vergelijiking tot de overige cliënten als meer coöperatief, meer volgzaam en meer verantwoordelijk beschrijven. Het betreft de 3 octanten die de eerste factor ('siamhorigheid") bleken te definierren (zie 3.3.3, tabel 3.4). 


\subsubsection{Gedragstekorten}

Octantscores van 4 of minder worden hiex beschouwd als een gedragstekort. Bezien we het percentage cliènten -per octant-met en gedragstekort (zie tabel 3.6) an kan geconstateerd worden dat tekorten in

Tabe1 3,6 Gedragsteikorten, in percentages

\begin{tabular}{|c|c|c|c|c|}
\hline & $\begin{array}{l}\text { Totale } \\
\text { steakproet } \\
(n-156)\end{array}$ & $\begin{array}{l}\text { Libo- } \\
\text { ciliërnten } \\
(N=94)\end{array}$ & $\begin{array}{l}\text { NLet- } \\
\text { LIDOA } \\
(M=52)\end{array}$ & $\begin{array}{l}\text { Versehil } \\
(\mathrm{p}<0 \mathrm{0})\end{array}$ \\
\hline s: & 32.7 & 35.1 & 29.0 & nee \\
\hline $\mathrm{DI}^{*}$ & 51.9 & 50.0 & 54.8 & neer \\
\hline TE & 7.7 & 6.4 & 9.7 & nee \\
\hline 10 & 9.6 & 11.7 & 6.5 & nee \\
\hline$O x$ & 7.7 & 5.3 & 11.3 & nee \\
\hline os & 19.2 & 13.8 & 27.4 & Ja \\
\hline so & 10.3 & 6.4 & 16.1 & ya \\
\hline $\mathbf{S E}$ & $B_{\text {in }} 3$ & 9.6 & 6.5 & nee \\
\hline
\end{tabular}

alle octanten voorkomen, vooral echter in de octanten BT en BS en, in mindere mate, in octant os; het betreft achtereenvolgens competitlef, leidend en afhankelijk gedxag. Daarnaast valt op dat Libo-clienten significant verschillen van niet-Libo's met betrekking tot os- en sotekorten: Libo-cliênten rapporteren minder tekorten in afhankelijk en cooperatief gedrag.

Een programma van sociale vaardighelastherapieën voor Libo-cliënten zal dan ook met name gericht dienen te zijn op de, overigens voor Libo's niet-specifieke, gedragstekorten in de actanten BT En BS. Van de 94 Libo-respondenten hebben er 24 zowel een BT als eeri BS-tekort, 20 alleen een BT-tekort en 6 alleen een BS-tekort.

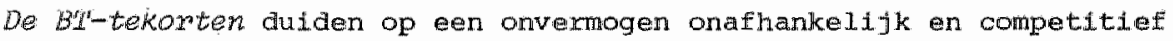
stelling te nemen, de ander(en) duidelijk te maken dat men lets betex weet of kan. BT-gedrag gaat gepaaxd net zelfvextrouwen en supexioriteitsgevoelens.

Het vermogen on vanuit deze interpersconlijke positie te opereren kan bevorderd worden door clienten (opnieuw) te leren op adequate wijze tegen anderen in te gaan, wanuit een heldere meningsvorming over het: 
standpunt van de andex deze ander op duidelijke wijze van repliek te dienen.

Wadere analyse van de subgroep Libo-cliërten met BT-tekorten wist uit dat lin deze groep vrouwen oververtegenwoordigd zifn: 64,38 van de vroumel1jke Libo-respondenten heeft een BT-tekort en slechts 28.98 van de mannelijke. Dit verschil is significant ( $\mathrm{p}<.001)$. Cok is er een significante relatie met de leeftijd. In de leeftijdsgroep van $19-30$ Jaar heeft 80.0\% een BT-tekort, in de groep 31 - 40 jarigen 33.3\%, van de ouderen 58.3\% (p<.01). Libo-clifinten met een BT-tekort hebben vaak (57.4y) ook een BS-tekoxt en/of een OT-exces (27.7\%). Op de or-excessen wordt nader ingegaan in 3.4 .3 .

BS-tekorten kunnen gezien worden als een onvermogen om leidend, sturend advisexend op te treden, invloed an aanzien te hebben, krachtig en energiek te handelen jegens anderen.

Het ligt woor de hand dit gedragstekort te verklaren met het gegeven dat Libo-clienten ook doorgaans de kennis, matschappelifke positie en ILnanciële mogelijkheden ontberen die het Innemen van eer BS-positie vaak legitimeren.

Dit argument wordt echtex ontkracht doar de bevinding at alt gedragstekort niet significant minder wordt aangetroffen bij niet-Libo-cliënten. BS-tekorten kunnen $0 . i$. bestreden worden door de betreffende clienten te leren invloed uit te oefenen op anderen doox op adequate wijze uitdrukking te geven aan hun meningen en gevoelens in interpersoonlijike situaties.

Bij vrouwen komen BS-tekorten vaker voor dan bij mannen (44.6 versus $21.2 \%$ p<.01). De Jongste leeftijascategorie lijkt enigsmins oververtegenwoordigd (53.3\%). Libo-clienten met een BS-tekort hebben voor het grootste deel (81.88) tevens een BT-tekort. Ook SB-tekorten komen veel woor in deze groep (21.2\%).

\subsubsection{Gedragsexcessen}

Een octantscore van 13 of meer worat als een gedragsexces beschonwt. Tabel 3.7 toont de pexcentages excessen per octant. 
Tabel 3.7 Gedragsexcesen, in percentuges

\begin{tabular}{|c|c|c|c|c|}
\hline & $\begin{array}{l}\text { Totalie } \\
\text { steekpitoet } \\
(\mathrm{N}=156)\end{array}$ & $\begin{array}{l}\text { Libo- } \\
\text { clifentan } \\
(\mathrm{N}=94)\end{array}$ & $\begin{array}{l}\text { Niet- } \\
E+b^{\circ}: \\
(N=62)\end{array}$ & $\begin{array}{l}\text { verschill } \\
\text { (P }<.011\end{array}$ \\
\hline $\mathbb{B S}$ & 5.11 & 6.5 & 3.2 & nee \\
\hline $\mathbb{B P}$ & 0.6 & 1.1 & 0.0 & nee \\
\hline $\mathbf{w B}$ & 3.2 & 4.3 & 1.6 & nee \\
\hline mo & 7.0 & 7.6 & 6.4 & nee: \\
\hline$O T$ & 21.1 & 21.3 & 21.0 & nee \\
\hline $\cos$ & 4.4 & 6.5 & 1.6 & nee \\
\hline so & 10.2 & 12.8 & 1.6 & Ja \\
\hline $\mathrm{sB}$ & 19.2 & 23.5 & 12.9 & $y \mathbf{a}$ \\
\hline
\end{tabular}

Gedragsexcessen komen minder voor dan -tekorten (vergelijk tabel 3.6). Opvallend hoog zijn de percentages excessen in de octanten or en SB: teruggetrokken en verantwoordelijk gedrag. Libo- en niet-Libo-clienten verschilien significant met betrekking tot SO- en SB-excessen; Libocliënten hebben vaker teveel coöperatief en verantwoordelijk gedrag. Interpersoonlijke vaaralgheidstherapieën voor Libo-cliënten zulien met name moeten inspelen op de voor deze groep specifleke sB-excessen, op de niet-Libo-specifieke or-excessen, en (in mindere mate) op de weltyplsche so-excessen.

Van de 94 Libo-respondenten hebben ex 8 zowel een SB-als een OT-exces, 14 alleen een SB-exces en 12 alleen een OT-exces. Van de 12 respondenten met een so-exces hebben er 9 tevens een SB-exces.

SB-excessen ciuiden op een overschot aan verantwooraelijk, helpend, redelijk, "volwassen" gedrag. Leary noemt mensen ale in extreme mate en op een rigide wijze hun toevlucht zoeken tot se-gedrag 'hypernoxmalen'. Zij vermijaen ledexe schijn van zwakheid, onconventionaliteit, passiviteit en, vooral, agressiviteit. Ernstige conflicten manifesteren zich bij hen vaak in psychosomatische symptomen. Presenteren zij al klachten van niet-somatische aard, dan hebben deze vaak betrekking op geIsoleerde fenomenen.

Beperken we ons tot de interpersoonlijke aspecten van de SB-excessen, dan Iijkt het geboden vooral aandacht te besteden an ce angst voor conflicten en het onvermogen hard, afwijzend, kwaad te zijn. 
Terwjl 40: van de Libo-respondenten van het mannelijk geslacht is, komt 50\% wan de sB-excessen voox rekening van mannen. Leeftija speelt in deze geen rol. Van de Libo-cliënten met een SB-exces heeft 40.95 een so-exces en 37.4 een or-exces.

so-excessen komen voor $75 \%$ voor rekening van respondenten met een $5 B-$ exces. Zij worden dan ook hier betrokken in de bespreking van de sBexcessen. so-excessen betekenen een teveel aan coöperatief, aanleunend gedrag, steeda weer proberen te behagen en aanvaard te worden.

De interpersoonilfke boodschap is ex een van "laten we geen ruzie maken". Eigen negatieve gevoelens worden niet onderkend, terwijl die van anderen ook bearelgend zijn. Cliênten met so-excessen lijken dan ook, evenals die wet $S B-e x c e s s e n$ het meest gediend met vaardigheden in het ongaan met kwaadheld.

Van de 94 Libo-respondenten hebben ex 20 een or-exces: overareven teruggetrokkenheid, gexeserveerdheid, schuchterheid. Deze cliënten doen zich voor als zwak, treurig en zwljgzaam. Zij voelen zich vaak angstig. schulaig of depressief en hebben weinig zelfwertrouwen. Waarschljnlijk ontberen deze cliënten een heel scala van interpersoonlifke vaardigheden. Hoewel zij uiteindelijk zouden moeten leren zich uitarukkelijk te (durven) poneren, hun meningen en gevoelens tot uiting te brengen, zullen zij aanvankelifk meer gediend zijn met meer basale vaardigheden, die als wegbereiders hen een opstap bieden on ult hun schulp te komen. Eenvoudige vaardigheden in het leggen en onderhouden van contacten en het reageren op actieve anderen zullen nodig zijn om. deze clfënten in statat te stellen hun passiviteit in te ruilen voor meer initiatief in interpersoonlijke situaties.

Van de Libo-clienten met een of -exces in onze steekproef is $70 \%$ van het vrouwelijk geslacht on $90 \%$ gehuwd $65 \%$ heeft een BT-tekoxt, $40 \%$ een BStekort, 40\% een SB-exces en 30 g een OS-exces. 


\subsection{Interpersoonlijke vaardigheden voor kansarmen}

De bovenstaande weergave van gedragstekorten en -excessen $(3.4 .2$ en 3.4.3) bevat reeds suggesties, 'vertalingen' in leerdoellen, zoals vardigheden in het ingaan tegen anderen, het ujtarukking geven aan meningen en gevoelens, het omgaan net elgen en andermans kwaadheid, het leggen en onderhouden van contacten en actief reageren op anderen.

\subsubsection{De vaardigheden}

Op grond van de geinventariseerde interpersoonlijke gedragsproblenatiek wordt van de volgende 9 interpersoonlijke vaaraigheden ingeschat dat vaardigheidstherapie-aanbod op dat gebied poorziet in een behoefte bij de Libo-clienten-populatie:

- een praatje maken

- Iuisteren

- lets bepraten

- reageren op kwaadheid

- reageren op genegenheid en waardering

- uiten van kwaadheid

- uiten van genegenheid en waardering

- opkomen voor je mening

- tegen anderen ingaan.

De eerste arie, een praatje maken - luisteren - lets bepraten, zijn eenvoudige vaardigheden in het leggen en onderhowen van contacten. Adequat reageren op gespreksinitiatieven, meningen en gevoelsultingen van anderen kan geleerd worden met de vaardigheden lulstexen-tegen anderen ingam - reageren op kwaadheid en reageren op genegenheid en waardering. Het uitdrukking geven an meningen en gevoelens is leerbaar met de vaardigheden: opkomen voor je mening - ulten van kwaadheld uiten van genegenheid en waardering. Het vermogen competitief stelling te nemen kan bevordexd worden met de vaardigheden: tegien anderen ingaan opkomen voor je mening - uiten van kwaadhedd. Cliënten die moelte hebben met het ongaan met eigen en andermans kwaadheid kunnen de vaardigheden ulten van kwaadheid en reageren op kwadheld lexen. 


\section{5 .2 De leerpunten}

De leerpunten beogen de betreffende vardigheid te beschrifwen in zijn discrete elenenten en de daarbij behorende volgorde. zij dienen de attentle te sturen van clienten die modelien observeren, een bemidaelende rol te vervullen bij de codering van de aar te relken gedragsinformatie en geschikt te zlin als (zelf-) instructie bij gedragsoefeningen en latere toepassingen van de vaardigheid.

Dit houdt tevens in dat zif in principe universeel toepasbaar moeten $z y_{n}$; niet in de zin dat elke adequate interpersoonlijke activiteit noodzakelijk volgens deze leerpunten verloopt, doch in de zin dat te werk gaan volgens de leerpunten in de meest uiteenlopende situaties adequat dient te $z j j n$. De eis van universele toepasbaarheid stat owerigens op gespannen voet met de eis van concreetheid en duidelijkheid.

Midels brainstoming, discussie en rolienspel in een groep van vier gedragswetenschappelijk geschoolde en therapeutisch werkzame leden van de projectgroep zijn pex vardigheid potentiële leerpunten gegenereerd, geintegreerd en getoetst.

Het maximum-aantal leerpunten per vaardigheld is, met het oog op geheugenbepexkingen, gesteld op 6 .

De resulterende sets leerpunten beschrijven soms hoe dan weer dat een bepalde activiteit dient te worden ondernomen. Instructies tot inspectie van situaties en tot zelfonderzoek worden afgewisseld met uitnodigingen betreffende overt gedrag en verbalisering van meningen of gevollens. "Terwijl ex enerzljas voor gewalat 1 s geen 'middenklassenormen" in te voeren, kunnen de leerpurten wel 'prosociaal' genoend worden. Driffueer darbly is niet geweest clienten an te passen (an welke norm dan ook), doch hen intexpersoonlijk gedrag aan te leren dat 'Ionend' i.s. Dat impliceert enerzijds dat expressie van gevoelens win meningen mogelijk moet zijn, anderzijds, om ongewenste verbreking wan contact te voorkomen en gewenste toenadering mogelijk te maken, dat voldoende rekening moet worden gehouden met de ander in de sociale interactie (Yardiey, 1979). 
De leerpunten die hieronder volgen, zijn tevens het resultat van ervaringen opgedaan met eerdere versies, die aanleiding hebben gegeven tot talrijke, overigens marginale, bijstellingen.

\section{Een praatje maken}

1. Ga na of je hier een praatje kunt maken

2. Kijk de ander aan

3. Groet de ander

4. Zeg iets over wat jullie beiden zien, horen of voelen

5. Let op de reaktie van de ander

6. Ga daax op in, of rond het gesprek af.

\section{Luisteren}

1. Kijk de ander aan

2. Toon interesse, met en zondex woorden

3. Vraag naar dingen die je niet begrijpt

4. Herhaal kort wat er gezegd is

5. Geef je elgen mening of gevael

6. Iet op de reaktie van de ander.

\section{Iets bepraten}

1. Kies een goed moment

2. Vertel de andex dat je wilt praten en waaxover

3. Vertel de ander wat je kwijt wilt

4. vraag wat de ander daarvan vindt

5. Luister goed naar de ander

6. Rond het gesprek af met een conchusie.

\section{Reageren op kwaadheid}

1. Luister aandachtig naar de ander

2. Laat merken dat je ziet dat de ander kwaad is

3. Vraag naar wat je er niet van begrijpt

4. Laat merken dat je begrijpt warom de ander kwaad is

5. Als je denkt dat nu het goede moment is: geef je mening of gevoel. 
1. Let op je lichaan (o.a. Je houding)

2. Ga na of je wat dwars zit

3. Ga na door wie of wat dat komt

4. Kies een goed moment on het te uiten

5. Laat horen dat je kwaad bent en waarom

6. Luister naar de reaktie van de ander.

\section{Uiten van genegenheld en waralering}

1. Ga na wat je prettig vindt an de ander

2. Beslis of je dat wilt leten merken

3. Kies een goed moment on het te uiten

4. Kijk de ander vriendelijk a an

5. Laat de ander merken wat je prettig vindt, met en zonder woorden

6. Let op de reaktie van de ander.

\section{Reageren op genegenheid en waardexing}

1. Let op wat de ander je aan genegenheid of waardering laat merken

2. Kijk de ander daarblj aan

3. Laat tot je doordxingen dat die andex lets van jou goed vindt

4. Laat merken dat je dat prettig vindt

5. Geef, als je wilt, de ander jouw genegenheid of waardering terug.

Opkomen voor je mening

1. Ga na wat je vindt van de situatie

2. Beslls of je voor fe mening op witt komen

3. Vertel die ander duidelijk en volledig je mening

4. Lujster natr de reaktie van de ander

5. Als je daarover niet tevreden bent, zeg dan je mening nog eens.

\section{Tegen de ander Ingatan}

1. Lulister goed naar wat de ander je vraagt of zegt

2. Vraag zonodig naar wat je er niet van begrijpt

3. Ga na op welke punten je het ex niet mee eens bent 
4. Vertel de ander duidelijk war je het niet mee eens bent en waarom

5. Let op de reaktie van de ander

6. Maak zonodig nog eens duidelifk war je in elk geval niet mee akkoord gaat.

\subsection{Samenvatting}

Teneinde de keuze wan interpersoonlijke vardigheden, op te nemen in ook qua leerdoelen sterk voorgestructureerde interpersoonlijke vaardigheidstnerapieën, enigszins te orderbouwen, is gezocht naar een uitputtende typologie van interpersoonlijke gedragswijzen. Gekozen is voor de interpersoonlijke gedrags-cirkel ("roos") van Leary, die ultgaat van macht en affiliatie als de fundamentele dimensies in interpersoonlijk gedrag en daarmee recht doet aan een groot aantal empirische bevindingen. Vervolgens is een op dit model gebaseerde vragenlijst, de Interpersonal CheckIist (ICL), aangeboden aan een steekproef van de cluentenpopulatie van het RIAGG-Maastricht om een indruk te krijgen van interpersoonlijke gedragsexcessen en -tekorten in de doelgroep. Na controles op het gebruikte instrument en het eraan ten gronaslag ilggende model worden de zelfbeschrijvingen van de doelgroep, cliënten uit lagere soclaaleconomische klassen, vergeleken met die van de overige respondenten. De doelgroep blijkt zichzelf als meer samhorig (meegaand, coöperatief, behulpzaan) te beschrijven dan de overige cliënten. Uit verdere analyses kan worden afgeleid dat velen in de doelgroep zichzelf weinig bedreven achten in leidende en competitieve gedragswijzen, terwijl velen teveel hun toevlucht zoeken in verantwoordelijk/helpend en teruggetrokken/verlegen gedrag. Op basis var deze bevindingen worden 9 interpersoonlijke vaardigheden vastgesteld tex opname in het aanbod van vaardigheidstherapleen. 
4. DE ONTWIKKELING VAM MODELBANDEN

Het produceren van modelbanden voor intexpersoonlijke vaardighedem is een middel on te bevorderen dat de nodige model- en modelingattributen, waarvan is aangetoond dat zij de effectiviteit van modelingprocedures verhogen (zie 1.3 .1 en 1.3.5), verwerkt worden in de vaardigheidstherapieën. Het werken met modelbarden betekent echter eveneens een volledige standaardisatie van een belangrijk onderdeel van het therapeutisch programa; vandaar dat relatief uitvoerig wordt Ingegaan op theoretische aspecten en practische ervaringen die bepalend zijn geweest voor de ulteindelijke vormgeving aan de modelbanden.

\subsection{Modeling: theoretische aspecten}

Eien interpersoonlijke vaardigheidstheraple dient cliênten in de geLegenheld te stellen responsinformatie, responsuitkomstinformatie en competentie-informatie te vergaren op zodanige wijze dat de interpersoonlijke varardigheid van de clienten toeneemt. Texwijl performanceaccomplishments de krachtigste informatiebron vormen voor responsLitkomst- en competentleverwachtingen zijn modeling-procecures de hoofabron voor responsinformatie en een aanvullende bron om vicarleus, responsuitkomst- en competentle-ervaringen op te doen. Vooral Bandura (1965a, 1965b, 1969, 1977a) heeft bijgedragen tot een groter inzicht in effecten van modeling en de daaraan ten grondslag liggende processen. 


\subsubsection{Mogelijke modeling-effecten}

Modeling, het demonstreren van gedragingen, kan bij de toeschouwers (observatoren) vier typen effecten teweegbrengen (Rosenthall en Bandura, 1978):

a. verwerving van nieuw gedxag.

Mensen kumnen nieuwe gearagspatronen en coping-strategieün aanlexen door de toepassing ervan door anderen te observeren. Onder nhewwe gedragspatronen verstaat men gedragssequenties, die voorhew noolt door het individu werden uitgevoerd, noch in witwoerbare vorm deel uitmaakten van zijn 'latente' gedragsrepertoire. Na observatie blijken mensen zowel in staat te zijn tot uitroering van nievwe deelresponsem als -en dat is in alt kader meer belangrijk- toc toepassing van complexe gedragspatronen, warvan de discrete elenenten reeds in het gedragsrepertoire aanwezig waren, doch die een reorganisatie en integratie van beschikbare deelresponsen vereisen.

b. (ont) remming van gedrag.

Iet observeren van de positieve of negatieve consequenties van door derden uitgevoerde gedragspatronen kan respektievelijk een disinhibexend of een inhiberend effect hebben op uitvoering van beschikbare gecragspatronen doox de observatox. Ook de door een observator wargenomen gelijkenis tussen het model en zichzelf kan van invloed zijn op de inhibities van de observator.

c. responsfacilitatie.

Modelgedrag kan analoge responsen oproepen bij observatoren, zonder dat er sprake is van verwerving van niew gedrag of cont-yreming van beschikbaar gearag.

d. Wijziging wan cognitieve standaarden.

Mensen reguleren hun gedrag op geleide van cognitieve standaarden, normen en verwachtingen met betrekking tot wat geëigend is in bepaalde situaties, eisen en yerwachtingen ten aanzien van elgen werichtingen, en dexgelijke. Observatile van gedrag van anderen kan (grote) invloed hebben op deze cognitieve standaarden.

Wak zullen gedragsveranderingen het gevolg $z$ in van een combinatle van modeling-invloeden: zowel vorming van nieuw gedrag als (dis) inhibitie van (ander) gedrag, wijziging van verwachtingen, etc. 
De mogelijke effecten van modeling zijn te verklaren doox de in 2.3 en 2.4 beschreven verwerking van informatle door het individu. Modelingprocedures kunnen de observator infomeren over gedragspatronen, over ultvoexders van dat gedrag en over consequenties van uitvoering van het gedrag in bepalde situaties. De presentatie van die infoxmatie is echtex geen garantie dat die informatie wordt wargenomen en onthouden, noch dat dat geschiedt op en wilze zoals bedoeld. Bovendien hoeft adequate informatie-verwerking nog geenszins te leiden tot de beoogde gedragsverander1ng.

\subsubsection{Determinerende processen}

Volgen:s Rosenthal en Bandura (1978) is de invloed van modeling op gedragsveranderling afhankelijk van (sub)processen van attentie, retentie, motoxische reproductie en motivatie. Zowel individuele vermogens als modeling - en ongevingskenmerken $z i j n$ bepalend voor het verloop van deze processen. Attentle-processen kunnen gehinderd worden door zowel de saatheld, irrelevantie, lange duux, snelheid, veelheid of onduidelijkheid van de aangerelkte (nodeling-) informatie als door irrelevante concurrexende stimull in de ongeving en door de emotionele toestand van de cliënt.

Eermal opgenomen infomatie kan snel verloren gaan. Opslag vereist symbolische transformaties, waarbij elementen kunnen worden verwijderd, gehercodeerd en van nieuwe betekenissen vaorzien. Hoe complexer de te coderen (en te onthouden) informatie, hoe meer informatieverlies er optreadt. De competentie tot motorische reproductie is in het kader van interpersoonlijke vaardigheden niet in het geding, tenzij ex sprake is van ernstige lichamelijke gebreken of aandoeningen. De motivatie echter des te meer.

Bandura (1977) steit dat motivatie mede afhankelijk is van (1) de capacitelt tot het maken van voorstellen ontrent toekomstige consequenties van gedrag en (2) het creëren en hanteren van standaarden voor het elgen gedrag.

of waargenomen en onthouden gedrag tot navolging zal leiden is dan ook afhankelijk van: 
- de door client van dat gedrag verwachte effecten

- de verwachting en de behoefte van de client tot ultwoering van dat gearag in staat te zijn

- de mate waarin de client de verwachte effecten wil bereiken. Bovendien is de mate waarin de aangeboden gedragsinformatie wordt waargenomen en onthouden afhankelijk van:

- de verwachting van de client dat hij in staat zal zijn tot attentie en retentie m.b.t. aangeboden informatie

- de verwachting dat attentie en retentie lonend zullen zijn

- de daaruit voortwloeiende inspanningen tot attentie en retentie

- de betekenistoekenning aan de aangeboden informatie

- bovenbeschreven factoren die van invloed zijn op attentie- en retentie-verlies.

Cognitieve processen bepalen dus zowel de motivatie tot attentie en retentie als de motivatie tot latere ditvoering van eenmal verworven varardigheden.

\subsection{Modelbanden voor interpersoonlijke vaardighe idstherapieën "}

De kwaliteiten van Goldstein's modeling-geluidsbanden zijn reeds besproken (zie 1.4.5 en 2.4). Op gestructureerde wijze dragen zij relevante en geloofwaardige responsinformatie, respons-ultkomstinformatie en self-efficacy-informatie aan. De combinatie van gedragsmodeling met instructies (leerpunten) is niet alleen te prefereren uit theoretische overwegingen met betrekking tot processen van attertiecodering-retentie-zelfinstructies, doch ook op emplrische gronden. Meerdere onderzoekers hebben aangetoond dat deze comblnatie effectiever is dan gedragsmodeling alleen of verbale instructies alleen 6. a. Green en Marlatt, 1972; Whalen, 1969, Spleglex, Llebert, MoMains en Fernandez, 1969). Marlatt (1972) omschrijft het verschil tussen

over dit onderwerp is eerder gepubliceerd door Beekers (1980). 
gedragmodeling en verbale instructies als volgt: terwij1 gedragsmodeling de presentate wan specifleke gedragingen inhoudt waarult de clent algemene princlpes moet afleiden, verschaft verbale instructie ("Instructiona1 coaching") algemene conceptuele principes waaruit de cileint de apecifleke gedragmatige aspecten moet afleiden.

Aanvankelijk zijn enige geluldsbanden geprodwceerd, geheel conform de opzet zoals gehanteerd door Goldstein. over de ervaringen daarmee en de wijzigingen die vervalgens zign doorgevoerd gaan de volgende drie paragrafen.

\subsubsection{Van audlo naw videomodeling}

De toepassingen van Goldstedn's vardigheldstherapieen met geluidsbanden als modeling-hulpmiddel leerden dat deze banden

a. essentide respons-informatie ontberen. De leerpunten benoemen regelmatig non-verbaal gearag zoals 'kijk de ander aan' of 'toon interesse, met en zonder woorden' en gedragingen met een belangrijk non-verbaal aspect, zoals "let goed op hoe...' Geluidsbanden zijn nlet in staat deze non-verbale gedragingen te tonen. Dit tekort kan slechts gedeeltelifk worden ondervangen door, zoals ook Goldstein deed, suggestleve gelulden en 'denk-spraak' toe te voegen (gedempte stem: '1k zal hem maar eens goed aankijken"). Het ontbreken wan informatie over non-verbale aspecten wan het te leren gedrag wreekt zich bovendien niet alleen bij 'non-vexbale leerpunten', doch in wellicht nog sterkere mate daar waar in de Leerpunten geen plates is ingerulma voox non-verbale aspecten.

15. onvoldoende in stat zijn de attentie te bevorderen. Tljerns het aanhoren van de nodelingband zien de cliênten elkaar. De aandacht voor de modelingsstimuli wordt regelmatig onderbroken en vexstoord door dominente visuele prikkels uit de groep. Modellen dienen aardacht op te elsen (Yussen, 1974).

on de attentie te bevordexen en meer respons-informatie aan te bieden 1.3 overgegaan tot de productie van videomodeling programma"s. Krumboltz en Thoresen (1969) zijn wan mening dat het gebrulk van film of video 'serves to focus the attention and minimizes distractions'. 
Bandura, Ross en Ross (1963) en Bandura en Menlowe (1968) concluderen op empirische gronden dat modeling middels film dezelfie effectiviteit heeft als live-modeling. O'Dell, o'quin, Alfora, O'Briant, Bradiyn en Giebenhain (1982) vergelijken de effectiviteit van trainingsmethoden ter verbetering van 'reinforcement skills' bij ouders en komen tot de bevinding dat, terwiji de effectiviteit van geschreven instructies en geluidsmodeling mede afhankelijk is van client-variabelen zoals sociaal-economische status, video-modeling consistent tot de beoogde gedragsverandering leidt wigeacht deze client-karakteristieken. Rosenthal en Bandura (1978) zijn var mening dat 'the mode of conveying information should count less than the ability to discern relevant cues and to organize them into cogent classes'.

Modeling met behulp van film of videoprograma's is -met succestoegepast bij onder meer de behandeling van sexuele dysfuncties (Nemetz, craig en Reith, 1978), sociaal vermijdingsgedrag (0'Connor, 1.969) en vliegfobieën (Denholtz en Mann, 1975). Een nlet te verontachtzamen nadeel van video- ten opichte van audio-modeling is natuuxlijk de kostenfactor.

\subsubsection{Van enkelvoudige voorbeelden naar contrastparen}

Ook videa-modeling is niet zonder meer in staat de attentie te sturen. Weliswaar krijgen concuxrerende visuele indrukken daarbij minder kans de aandacht af te leiden van de gepresenteerde scène, dan nog blijken in de aangerelkte audiovisuele informatie zelf voldoende elementen aanwezlg te kunnen zijn dife de aandacht afleiden naar irrelevante aspecten. De voorbeelden biljken een veelheid stimuli te kunnen inhouden, warin clienten niet gemakkelijk de relevante gedragsinformatie kunnen onderscheiden van 1 rrelevante 'ruis'. Een woorbeeld moge alt iliustreren.

Toen him, een 48-jarige huisschilder, aan de beurt was voor een gedragsoefening, toonde de therapeut hem een video-voorbeeld dat wim zekex zou aanspreken, en dat nog niet eerder aan de groep was aangeboden. Hat gebeurde In een groep met 'Iutsteren' als doelvaardigheid en Wim had 'thuis, met echtgenote' gekozen als oefen- en huiswerksituatie. Het videovoorbeeld speelde zlch af in een huiskamer en de hoofdrolspeler was, evenals win, een 
arbelder van tegen de 50 . De echtenotye in het videovoorbeld gaf blijk van haar bezorgaheid over het feit dat de kinderen voor de eerste mal alleen zouden achterbilfuen als het echtpaar op vakantie zou gaan. De man reageerde conforn de leerputien laankjjken - interesse tonen doorragen - samervatten, enz.). Toen de therapeut na afloop van de scêne aan Win vroeg of hij aan dit woorbeeld had gezien 'hoe hij het zelf kon doen" schudde deze ontkeminend zijn hoofd en antwooxdde: "Wij hebben geen kinderen'.

Besloten is over te gaan tot deproductie van 'contrastparen": twee video-scërnes, die direkt na elkaar worden getoond en zoweel mogelijk gelijk zljn natar situatie, aanloop van de scène en irrelevante gedragskenmerken, doch duidelijk verschillen met betrekking tot de leerpunten. In de eerste scène woxden de leerpunten nièt toegepast, in de tweede wel. Loox presentatie van een contrastpaar, gepaard aan de instructie 'op het verschil te letten', wordt de attentie gexicht op de relevante modelgedragingen.

BIj de ultwerking van dit grondidee zijn nog enige elementen aan de opzet wan de model-banden toegevoegd:

a. De scène-met-leerpunten dient een betexe 'afloop' te hebben dan de scène-zonder-leerpunten. Daarmee wordt in de video-modeling de bevinding wan Bandura (1965a) en Bandura, Ross en Ross (1963b) benut dat modelgedrag gevolgd door gunstige consequenties een grotere kans op navolging heeft. Om de geloofwaardigheld van het voorbeeld geen geweld aan te doen en on niet de indruk te wekken dat toepassing van de leerpunten steeds tot positieve gevolgen leidt, geschiedt de vormgeving aan dit principe genuanceerd: scênes-met-leerpunten kxijgen wak een "oper" afloop, de scèneszonder-leerpunten hebben in die gevalien echter wel een 'slechtere' afloop voor de hoofarolspeler.

b. Door in de scêne-zonder-leexpunten de hoofdrolspeler gedrag te laten vertonen dat typisch is voor cliënten, zal dit model als een realigtische referentiefiguur gezien worden (Brown, Brown en Davidson, 1975, Kanfer, Karoly en Newman, 1974), en zal het te bieden gedxagsalternatief als relevanter en meer haalbaar worden beschouwd (Kazdin, 1974). 
Een voorbeeld van zo'n uitwerking: de videoband voor de vaardigheld 'witen van kwaadheid' toont in de scênes-zonder-leexpunten achtereenvolgens lemand die zijn kwaaheid 'inslikt', ienand die zijn kwaadheld uit tegenover een onschuldige (hulsgemoot) en iemand die op schadelijke, destructieve wijze zijn kwaadheid uit.

Met deze maatregelen worden zowel respons-imformatie als responsuitkomst-informatie en self-efficacy-informatie aan de modeling-banden toegevoega.

\subsubsection{Naar contrast-paren met eenzelfde hoofdrolspeler}

De invoering van contrastparen is een gelukkige formule gebleken. Leerpunten worden eerder herkend, de minder goede afloop van de scèneszonder-leerpunten voor de betreffende hoofdrolspelec wordt door cllënten duidelijk oggemerkt en vaak nog versterkt ('Hij heeft nog geluk gehad, het had net zo goed...'). termijl spontane meldingen van herkenning van een falende hoofdrolspeler ("zo gat het mij nou ook altijd") meer regel zijn dan litzondering.

Door toevallige anstandigheden is het enige malen voorgekonen dat de acteur die de hoofdrol vervult in de scène-met-leerpunten nilet dezelfde is als die in de scène-zonder-leerpunten. In die gevallen zijn beide acteurs wel van dezelfde sexe, leeftija en dergelijke. Het tonen van. beide scènes aan de cliëntengroep heeft in die gevallen regelmatig een ongewenst effect: de herkenning van en identificatie met de acteurzonder-leexpunten brengt cliënten tot verklaringen in de orde van 'ik ben meer zoals die persoon; ik kan het ook niet". Contrastparen met. eenzelfde hoofdrolspeler brengen de cliënten daarentegen meex op het spoor van de gedragsalternatieven die men in bepalde situaties heeft: 'toen hij het zó aanpakte, ging het veel beter'. Terwijl de inzet van verschillende acteurs kennelijk die aanwezigheid van 'winnaars' en 'verliezers' suggereert, waarblj cliënten zich vaak tot de eeuwige verliezers rekenen, heeft het optreden van eenzelfde acteur een meer tot gedragsverandering uitnodigende invloed. Deze praktijkervaringen ondersteunen in felte Bandura's self-efflcacytheorie en zijn illustratief voor bevindingen dat modellen die 
aanvankelifk het angst- en faalgedrag van cliênten vertonen voordat zHj het meer adequate gedrag toepassen als nodel effectiever zijr dan "mastery" modellen (Kazdin. 1974). Het tonen van eenzelfde hoofarolspelex in het 'foute" en het "goede" roorbeeld is een extra middel om nast respons- en respons-ultkonst-informatie ook informatie aan te bieden "die persoonlitye verwachtingen van elgen competentie in gunstige zin kan be Invloeden.

Die warwachtingen betreffen in dit geval net name het geloof tot gedragsverandering in stat te zijn.

De Inzet van eenzelfae hoofarolspeler in contrastscenes is tot regel. verheven. Voor elke interpersoonlijke vaardigheid is een videoprograma geproduceerd. Steeds wordt een deskundige lpsycholoog, psychiater, hoogLexaar) getoond die de waxdigheid en de leerpunten introduceert, waarna 3 contragtparen volgen. Ter bevordering van de stimulusgeneralisatie (transfer) spelen de scênes zich steeds af in 3 levenssferen: een huiselijk milieu, een arbeidssituatie en een situatie uit het openbare leven.

De acteurs zifn 'gewone' mensen uit het milieu van de doelgroep. De scernes hebben betrekking op alledaagse, herkenbare en relevante gebeurtenissen warin de betreffende interpersoonlijke waardigheid onmiskenbaar zijn dienst bewijst. 
5. HEI THERAPIE-PROGRAMMA

Goldstein (1976) heeft zijn 'handleiding" geen protocoldair karakter gegeven. Hij spreekt van 3 à 15 graepsbijeenkomsten, afhankelijk van het niveau van de deelnemers en het aantal te leren vaardigheden, pleit voor een "classroan"-achtige inrichting van de groepsruimte en voor het creären van ruimte voor rollenspel "in alle mogelijke vormen" . verder rekent hij er kennelijk op dat zijn eventuele navolgers zich bij de vormgeving aan het therapie-programa houden aan de hoofacomponenten var modeling, rollenspel, bekxachtiging en transfex-training en deze toepassen op een wij̈ze die recht doet aan de empixische bevindingen betreffende factoren die de effectiviteit ervan bepalen (zie 1.3).

In 2.4 is Goldstein's structured learning therapy geherwaardeerd in het licht van het cognitief soclaal-leextheoretisch model, meex speciaal Bandura's self-efficacy-theorie. Geconstateerd is dat de hoofdcomponenten van de structured learning therapy de basis vormen voor een therapieprogramma dat elienten in staat stelt op gestructureerde wifze respons-, responsultkomst- en self-efficacy-Infomatie te vergaren. Vooral het laatste, het vergroten van competentie-verwachtingen, wordt op de meest directe en krachtige wijze gefaciliteerd, namelijk via pexformance accomplishments.

De wijze warop dit kan worden bewerkstelligd wordt hieronder beschreven en toegelicht. De merkwijze is het resultaat van theoretische overwegingen en practische ervaringen; de beschrijving exvan dient tevens als handleiding voor therapeuten. 
Elke vardigheldstherapie is gericht op het anderen var én vaaxdigheld. De therapie wordt uitgevoerd door 2 therapeuten en onvat 4 wekelijkse bijeenkonsten van elk 2 uur. Het aantal deelnemers bedraagt 5 a . De deelnemers zijn afkomstig wit de lagere socual-economische strata en zijn in behandeling blj een instelling voor geestelijke gezondheldszorg. Een client wordt naar een vaardigheidstherapie verwezen ondat zowel de verwijzer als de cliënt zelf van oordeel zijn dat de client de vaardigheld die op het programma staat lae doelvarajgheid) onvoldoende kan hanteren, terwijl.

- het niet kunnen hanteren van die vaaxigheid (een onderdeel van) het centrale probleem is, of

- het kunnen hantexen van die vaardigheid een noodzakelijke voorwarde is tot uitvoering van het behandelingsplan, of

- het ontbreken van de doelvaaxdigheld het centrale probleem (mede) in stand houdt, of

- verwacht wordt dat de client, eemmal uitgerust met de doelvaardigheid beter in staat zal zijn toekomstige problemen zelf het hoofd te bieden of te voorkomen.

Doorgaans worden cliënten voor 2 of 3 vaardigheden opgegeven ( $z i e$ bljlage 1: Verwijzen naar Goldsteintherapieën.)

In de groepsruimte staan stoelen gegroepeerd in U-vorm, waardoor alle aanwezigen goed uitzicht hebben op het ten nooxden van deze U-vorm gelegen gedeelte van de ruimte dat dient als 'speelvlak', en tevens op een terzljde van dit speelvlak opgestelde videomonitor.

Van de vaardigheld is een videoprogramma beschikbaar, zoals beschreven in hoofdotuk 4 .

Aan of langs de wand is een plaat bevestigd warop de titel van de doelvaardigheld en de daaxbij behorende leexpunten staan vermeld. De therapeuten beschikken verder over een video-recorder, een flap-over

over dit onderwerp is eerdex gepubliceerd door Beekers en Gooijen (1980). 
en huiswerkboekjes (dit zijn eenvoudige boekjes van klein formaat warin de leerpunten vernela staan en voor elke week een pagina is gereserveerd am huiswerkopdrachten te noteren).

\section{1 .1 De introductie}

Aan het begin van de eerste groepsbijeenkonst vindt een korte introduktie plaats.

Achtereenvolgens vinden de volgende activiteiten plaats:

- De therapeuten introduceren zichzelf als zodanlg:

'ik ben ... en ik doe deze groep met ... daar" .

- Het thema van de groep wordt genoemd en tegelijkertijd gebruikt an de clienten enige 'gemeenschappelijkheid' aan te reiken: "we $z$ jjn dus hiex on te leren... jullie hebben allemal wel eens moeite met .....

- De cliënten worden uittgenadigd zichzelf te introduceren met hun voornaam en hun startpositie ten aanzien van de te leren varaigheid: 'het is prettig als we alvast elkaars voomaam weten. Hoe heet jij? (de naam wordt op de flap-over geschreven). Wat vind jij moediljk aan....?

De therapeut richt zich steeds tot een cliennt, nooit tot "de groep".

- In het kort wordt (de status van) de vaardigheid en de werkwijze in de groep toegelicht: 'wij willen fullie een manier leren var... Dat is miet per se de enige goede manier, maar deze werkt in elk geval. Als ge deze manlex geleerd hebt, kun je later bekljken of je daar voor jezelf dingen in verandert. Op de video hebben we een aantal voorbeelden van... daar gaan we zo naar kijken. En verder gaan we vooral veel aefenen, alat doen we där (wijst naax het speelvlak)'.

- Clienten worden exop gewezen dat het specifleke leerdoed hen ook beperkingen oplegt: 'we hebben matar 4 bijeenkomsten, en die zullen we volledig besteden aan het oefenen van ....'

- Vervolgens wordt de videoband gestart en worden de clienten uitgenodigd 'goed op te letten'. Daarmee is de modeling-fase van het eerste imiterend rollenspel gestart. 


\section{1 .2 Het jnitexend rollenspel}

In het interend collenspel worden toepassingen van de vaaraigheid getoond en worden de clienten vervolgens beurtelings in de gelegenheia gesteld het getoonde na ter bootsen.

Het verloop is als volgt:

a. De therapeut toont de clienten twee scenes op de video warvan de eerste, waar in de leerpunten niet worden toegepast, minder bevredigend verloopt dan de tweede, die op een aantal punten (spelers, situatie, begin van de scenel ldentiek is aan de eerste, dach waarin de hoofdrolspeler de leexpunten wèl toepast.

Daarop volgt een korte, gerichte nabespreking. De therapent die vraagt "wat hebben jullie gezien?" zal weinig antwoorden krijgen en veel tija verdoen. Gekozen wordt dan ook voor gerichte vragen in de trant van 'Miep, heb jij leerpunt 1 gezien?', gevolgd door "wat deed die man dan precies?" " Zonodilg worden de leerpunten door de therapeut nacier toegelicht.

De scène-met-leexpunten wordt vervolgens nog eenmal getoond, nu met de instructie 'goed op te letten, want dadelijk gaan we dit naspelen'.

b. Een der thexapeuten staat op, begeeft zich naar het speelvlak en definieert daar de situatie die zoëven wera getoond: 'hier is dus die wachtkamer, hier staan de stoelen" (grijpt stoelen), "hier staat die grote plant" (gebaart in het luchtledig); 'Peter, kom eens, jij bent die man .... jlj zilt de krant te lezen' lreikt Petex een stuk papier a an); "nu kont dus die meneer oudmans binnen. Francine, jij als eerste, jij bent meneer oudmans, je komt binnen en je doet precies zoals meneer Oudmans op de video deed'. Door snel, luchtig en vanzelfsprekend op te treden geeft de therapeut de cliënten weinig kans te blifven "steken" in hum weerstand of angst. Een weigering on het speelviak te betreden komt zelden voor. Tegensputteren zal voor de therapeut aanlelding zijn de client te gaan "halen": "uitgestoken hand) 'kom op Miep, jij doet ook mee.... we doen allemaal mee.... ik help je wel". 
c. De therapeut start het spel: 'begin maar', houdt zich gedurende het spel op aan de rand van het speelvlak, en beeindigt het spel: "stop maar" (kappend handgebaar). Onmiddellijk bekrachtigt hij de gedragingen van de protagonist die beantwoordden aan de alverse leerpunten: "uitstekend, je deed ..... en dat is leerpunt ...." . Gedragingen die afweken van het getoonde modelgedrag, doch evenzeer beantwoordden aan de leerpunten, worden extra bekrachtigd: 'weet je wat ik goed vond? Je deed ...... en dat is precies wat bedoeld is met leexpunt ...'. De therapeut schakelt de overige aarwezigen in bij de bekrachtiging: 'zag jij dat ook? Hoe vond je dat?'.

Daarop zal de cotherapeut zich in elk geval aansluiten bij de therapeut en waar mogelijk additionele gedragingen bekrachtigen. De antagonisten worden slechts bedankt voor hun deelname: 'fijn dat je meedeed, Peter". Als de verrichtingen van de protagonist vanaf de start van het rollenspel op een duidelijke mislukking dreigen ult te lopen onderbreekt de therapeut het spel zo tijdig mogelijk, reduceert de opdracht an de protagonist tot een halbare proportie (een eerste deel van het te imiteren gedrag), schakelt eventueel zijn cotherapeut in on als model dit gedrag nog eens te demonstreren en laat dan zijm protagonist opnieuw starten.

De protagonist zal niet direct àlle leerpunten adequaat uitvoeren. Als het de eerste maal is, dat een imiterend rollenspel plaatsuindt. zal de therapeut genoegen nemen met de aanwezigheid van enkele leerpunten, bij voorkeur de eerste arie. Als de protagonist er niet in geslaagd is dit "criterium" te berejken zal de therapeut een "sinaping-procedure" toepassen: dezelfde protagonist herhalt zijn rollenspel-verrichtingen enige malen, steeds met toevoeging van een paar nieuwe gedragselementen, totdat aan het criterLum is voldaan. Het falen van de protagonist met betrekking tot de realisering van een leerpunt, wordt niet expliciet als falen benoend, maar krijgt de vorm van een ultnodiging om "het $n u$ nog eens te doen met .... erbij". De bekrachtiging wordt steeds gericht op de 'winst' : de toegevoegde gedragingen ("goed John, nu toonde je duidelijk interesse doox af en toe met je hoofd te knikken'). Als de protagonlst niet goed begrifpt wat er van hem verwacht wordt, of duidelijk moelte 
heeft met het stellen van het gevradgde gedrag. kan de the rapeut een korte modeling doen plaatsvinden, waarbij hij zijn cotherapeut inschakelt als model an de modeling beperkt tot die verrichting(en) warl de protagonist moeite mee heeft. Als het criteriun bereikt is, neemt de therapeut zijn protagonist mee terug naar zijn plats in de groep.

d. De tweede therapeut, tot nu toe aangeduld als cotherapeut, nodigt de volgende cliënt uit met hen mee te gaan naar het speelviak ("nu wil. Annelies') en werkt met deze protagonist stap a door. De eerste therapeut gaat vervolgens met de dexde protagonist werken, enzovoorts. Ook de cllenten, die een rol toebedeeld kregen als 'vaste' antagonisten, krijgen tenslotte een 'beurt' als protagonist en daarmee en kans de vaardigheld te (leren) stellen. Het imiterend rollenspel wordt toegepast tijdens de eerste twee groepsbijeenkomsten.

\section{1 .3 Het anticiperend rollenspel}

In het anticiperend rollenspel worden modeling en gedragsoefiening volledig afgestem op de situatie zoals de individuele client verwacht dat die zich in de nabije toekomst zal gaan voordoen. Men kan zeggen dat de cliënt zich voorbereidt op het 'huiswexk' van de komende week. Het verloop van een anticiperend rollenspel is als volgt:

a. Als de client, die "aan de beurt is" , niet direct een situatie inbrengt, die hij exdaags verwacht of die hij reeds enige tijd vermijat, dan gat de therapeut met zijn client op zoek naar een 'geschikte hulswerksituatie': 'waar zou jij komende week de leerpunten bens kunnen uitproberen; wat zou je kunnen gaan doen?' Als de olient welnig gedreven reageert ('ik heb geen plamen deze week") dan zal de therapeut meer druk ultoefenen: "Nou dan máken we toch plannen. Kow Marlies, denk eens na, waar of bij wie ...'. De therapeut zal ex bij de keuze van de oefensituatie naar streven te voldoen aan

- het principe van geleidelijke toenadering als het een angstige client betreft. Dit worat ook aan de client kenbaar gemaakt: "dat 
is well een hele moeilijke situatie, niet? Je mag rustig wat eenvoudiger beginnen. Als dat gelukt is, nemen we later wel de moellijker situatie".

- het principe van stimulus-variatie: als de cliênt een situatie en/of relevante andere noent die voordien al in een anticlperend rollenspel voorkwam, dan zal de therapeut hem daarop wijzen en vragen nu een andere situatie te kiezen ("Met je vader hebben we vorige week al geoefend, André, laten we nu eens een andere situatie nemen. Met je vrouw, of op je werk').

b. Zodra cie situatie gekozen is, staat de therapeut op, neemt zijn protagonist mee naax het speelvlak en vraagt de cliënt de situatie nader te beschrijven. Ondat het een gebeurtenis betreft die nog niet heeft plaatsgevonden, kan de protagonist soms een aantal situatiekenmerken niet precies geven ('ik weet niet hoeveel mensen er in die winkel zullen zijn'). Het 'aankleden' van de scène zal dan ook enige improvisatie van thexapeut en spelers toelaten. Troch zal de thexapeut zoveel mogelijk elementen van de situatie door zijn protagonist laten definiëren. Enerzijds om de protagonist de kans te geven zijn fantasieën over de situatie, over de relevante ander(en) en over wat er kan gebeuren zoveel mogelijk ruimte te geven, andierzijds amdat de protagonist bij zijn definiëxing van de situatie zijn eigen huiswerkopdracht concreter gaat invulien ('ja, ik geloof at ik dat het beste vrijdagmiddag kan doen; na het eten; dan zitten we dus....'). Van een aantal van deze elementen woxdt "afgesproken" dat ze op de door de protagonist aangedulde wijze aarwezig zijn. Een toevallig aanwezig tafeltje kan de functie van bijvoorbeeld een toonbank kxijgen, doch de aanwezigheld van requisleten is niet noodzakelyk. Regelmatig komt het voor dat de protagonist in een later stadium van het rollenspel zijn imaginaire situatie "verdedigt' door bijvoorbeeld een antagonist erop te wijzen "dat hif dwars door de muur loopt, en dat kan niet: dáx is de deux". De protagonist kiest op ultnodiging van de therapeut "wie in de groep lijkt daar het meest op?") zijn antagonist (en). De gekozene, meestal mede-client, soms therapent, wordt naar het sperelviak gehaald en geinstrueerd: "jij bent de winkelier, meestal ben je nogal ...." en wordt wooraf het moment dat hij het speelvlak betreedt aangesproken met....., met de maam van de relevante ander die hij vertegenwoordigt. 
In het gewal dat de naam onbekend is of niet gemomd kan worden wordt hij consequent aangesproken in de hoedanigheld die hij van de protagondst heeft gekregen ('de whkelier" of "de nieuwsgiexige buurman

c. De protagonist wordt nu gevraagd nader in te vullen in woord en/of spel hoe hij werwacht dat de gebeurtenis een aanloop zal nemen: 'je hebt dus net je laatste hap genomen, en nu?'. Deze fase wordt gekapt op het 'kritische moment' : het moment dat de vaardigheid gesteld moet gaan worden.

d. Wu vindt modeling plaats. De therapeut nodigt de protagonist uit plaats te remen op en stoel van waaruit hij goed zicht heeft op wat ex zich op het speelvlak gaat afspelen: 'jij neemt nu hier op de 'tribune" plaats, dan gaan wij voordoen hoe het met leerpunten zou kunnen gaan". De therapeut laat enige malen het spel plaatswinden bestaande uit (een deel van) de danloop en de leexpunten en met een of twee mede-clienten (eventueel ale cotherapeut) als model. Het model wordt steeds duldelijk geinstrueerd: 'jij bent nu André. Je hebt je voorgenomen on .... Je begint met de laatste hap te nemen. Je zorgt daarna dat je de leerpunten toepast. Toe mar'. Elke modeling wordt gevolgd door:

- de vraag aan de toekijkende protagonist of het 'klopte' ("zou jouw vrouw zo kunnen reageren?').

- de vraag aan de protagonist wat hij wan het model positief en voor hemzelf haalbaar acht ('Wat zou je van deze André willen overnemen?). De protagonist kiest doorgaans per model éen of twee gedragselementen: een non-verbal gedragskenmerk, een gebruikte zinsnede of iets dexgeldjks.

- een vertaling van het over te nemen gedrag in leerpunten.

- oen bedankje aan het model met de uitnodiging weer plats te nemen in le groep.

e. De therapeut nodigt de protagonist uit zijn elgen plaats in het rollenspel in te nemen: "nu jif zelf Andre'. Aarn de rand van het speelvlak laat hij de protagonist zichzelf haxdop instrueren: 'zeg nog eens wat je nu gaat doen", en start dan het rollenspel. Bij bedindigling van het rollenspel bekrachtigt de therapeut de gerealiseerde voornemens/leerpunten en betrekt de aanwezigen daarbif. 
Weer dan in de andere typen rollenspelen gat de therapeut nu echter te radebij de protagonist: "ben je zelf tevreden, Anare?" "De protagonist, die in het anticiperend rollenspel minder "wrjiblijvend" bezig is, ondat hij zich realiseert dat het in luttele dagen "menens" wordt, zal vadk met onvoorziene eisen of addertjes onder het gras voor de dag komen ('ik wil niet dat die ander denkt...." "als ik het zo doe, dan blijf ik toch zitten met dat gevoel van ...." . De therapeut zal naar aanleiding daarvan de protagonist de gelegenheld geven additionele gedragingen te vinden en uit te voeren in het rollenspel. Afhankelijk van de mogeljjkheden van zijn protagonist zal de therapeut daarbij meex of minder directief optreden (respektievelijk 'zeg dan an het eind eens tegen je vrouw: ...." or' wat. kun je zeggen of doen on dat te voorkomen?'). Shaping wordt toegepast totdat leexpunten, voornemens en additionele eisen gestalte hebben gekregen. Als de bedenkingen van de protagonist niet-terecht zijn zal de therapeut deze ontzeruwen door de antagonist(en) en/of toeschouwers hun indrukken te laten geven.

E. Terwijl de therapeut en zijn protagonist weer in de groep plaatsnemen, begeeft de cotherapeut zich naar de flap-over on de huiswerkopdracht te noteren: waax, wamneer, net wie, speciale tips. Hoewel ook de therapeuten en mede-clienten 'tips' aandragen, worden bif voorkeur de tips die de protagonist noemt of overneent genoteerd" warbij de formulering die de protagonist daaraan geeft intact wordt gelaten. Tot slot wordt de protagonist succes toegewenst en eraan herinnerd dat op zijn huiswerk zal worden teruggekomen. Vaak. wordt de protagonist uitgenodigd zelfbekrachtiging toe te passen als hij zijn huiswerkopdracht voltoolid heeft.

Doel van het anticiperend rollenspel is de protagonist

- gelegenheid te bieden te experimenteren met wijzen warop hijultarukking kan geven aan de vaardigheid in zijn eigen levenssituaties.

- te motiveren om de leerpunten in zijn eigen dagelijkse omgreving toe te passen.

- zodanig voor te berelden en te instrueren dat de kans op succes blj de toepassing van de vaardigheid in eigen levenssituaties optimal is. 
Vanaf de tweede sessle is elke cllent in elk geval eenmal per groepgbijeenkonst protagonist in een anticiperend rollenspel.

\section{1 .4 Het reconstruerend rollenspel}

Het reconstruexend rollenspel biedt de cliënt gelegenheid een situatie waarin hem het stelien van de vaardigheld in het verleden nlet of onvoldoende lukt te reconstrueren en alsnog bevredigend te doorlopen. De oliznt krijgt in dit rollenspel als het ware een 'herkansing'.

De therapeut beslist tot het opzetten van een reconstruerend rollenspe:1:

- indien een cliënt spontaan een gebeurtenls melat, waarbij hij er niet in slaagde of verzulmde de vaardigheid toe te passen.

- Indien een cliënt een faalexvaring rapporteext met betrekking tot een hulswerkopdracht. Faalervaringen met huiswerkopdrachten dienen overigens zoveel mogelijk voorkomen te worden. De thexapeut kiest dan ook steeds huiswerkopdrachten waar de client aan toe is. Desondanks komen faalervaringen voor, en het is finuikend deze te laten liggen, en dus nodig de cliënt een 'herkansing' te geven in de groep.

Doel van het reconstruexend rollenspel is de protagonist de kans te geven de vaardigheid te stellen in die situatie waarin hem dat voorheen nlet lukte en dit te (doen) bekrachtigen, waarmee de betrokken situatie als discriminatieve stimulus(klasse) voor het stellen van de vatardigheid behouden blijft.

Het reconstruerend rollenspel verloopt aldus:

a. Op auniyzingen van de protagonist wordt het speelvlak "aangekleed". Ondat het voor een groot deel een reconstructie betreft van een ware gebeurtenls ult het verleden, dient er veel aandacht besteed te worden aan het aankleden van deze situatie, aan het kiezen en instrueren van antagonisten, enzovoorts. Doet men dit niet dan zal de protagonist vaak een "geslaagd" rollenspel later afdoen met opmerkingen in de trant van: 'ja, nu lukte het wel, maar toen was het ook heel anders'. 
b. De protagonist wordt nu gevraagd te verduideligken wat ex vooraf ging aan het kritische moment: het moment warop hij falde of verzaakte. De therapeut kapt dit gedeelte af op het moment dat de protagonist wil gaan verwoorden of voordoen hoe hij faalde. Het rollenspel heeft immers noch de bedoeling het inadequate gedrag te analyseren, noch an (warschijnlijk negatieve) feedback op te roepen.

c. De therapeut noaigt de protagonist. nu uit op de "tribume" plats te nemen, nodigt een groepslid of zijn cotherapeut uit de plaats van de protagonist in het rollenspel in te nemen, en start het spel, na het model te hebben uitgenodiga daarin in elk gevall de leerpunten toe te passen. Als de protagonist na afloop anmerkingen heeft op het inhoudelijke verloop " hij zei dat hij het al wist, maax dat was niet $20^{\prime \prime}$, dan wordt de modeling herhald, waarbij het commentaar als correcties in het spel worden verwerkt. De thexapeut laat vervolgens nog éen- of tweemaal modelen, steeds met een nieuw model doch met dezelfde antagonist. Elke modeling wordt weer gevolgd door - de vraag aan de protagonist of het 'klopte' - de vraag aan de protagonist wat hij hiervan wil 'overnemen"

- een vertaling van het antwoard van de protagonist narar de leerpunten.

d. De protagonist kan nu zijn "eigen' plaats in het rollenspel innemen. De therapeut neemt aan de rand van het speelvlak zijn "voornemens" met hem door: de 3 of 4 door de protagonist zelf lit het modelgedrag geselecteerde gedragingen. Doorgaans zal de protagonist ex niet in slagen al zifn voornemens direct waar te maken, en zal shaping volgen.

e. Als de oefensituatie zulks toelaat, wordt tenslotte huiswerk opgegeven, conform fase $\mathrm{f}$. Van het anticiperend rollenspel. Sons Is dit nilet het geval: sommige gebeurtenissen laten zlch eenvoudig niet 'overdoen' .

Ondat reconstruerend rollenspel niet altija tot huiswerkopdrachten leidt en bovendien vaak veel tijd vergt (de protagonlst stelt hoge eisen aan de reconstructie van de ware gebeurtenis) is het voor de therapeut geen vast programma-onderdeel on naar toe te werken. Doet zich echter een van de gernoemde aanleidingen voor, dan wordt het 
evenmin vermeden. Een erkele mal blijkt in een vroege fase var het reconstuerend rollenspel dat de protagonist cen voorval inbrengt, warin hil wel degelijk de leerpunten adequat toepaste en desondanks spreekt van een faalervaring.

Dit 'falen' heeft an nlet betrekking op zijn eigen gedragingen maar op het uitblijven van de "winst" die hij van zijn gedrag verwachte of $o p$ de tegenvallende reactie van andere betrokkenen. In dergelijke gevaluen wijst de therapeut zijn cliert erop dat het stellen van de vaardigheld niet betekent dat je steeds je zin krijgt, noch dat de anderen daar altijd even gelukkig mee zijn, 'het gat exom dat jij in elk geval in staat bent om....."

\subsubsection{De hul swerkbesprekingen}

De eerste huiswerkbespreking vindt plaats aan het einde van de eexte groepsbljeenkonst. In deze bespreking

- worden het huiswerk-beginsel en het huiswerkboekje geintroduceerd.

- worden de eerste huiswerkopdrachten gegeven. Het huiswerk na de eerste zitting is min of meer 'standarard' :

a. observeren van anderen ("kilk eens hoe andere mensen het doen, of die de leerpunten toepassen en hoe je dat vindt'y

b. het toepassen van de ériste leerpunten, die doorgaans voornamelijk 'bedekte' (coverte) gedragingen inhouden.

- worden de cliënten uitgenodigd de gemaakte afspraken in hun hulswerkboekje te noteren. cliënten die dit niet kunnen doen, worden onopvallend geholpen.

- wordt de clienten reeds aangekondigd dat elke volgende zitting begint met en bespreking van het huiswerk en dat erop gerekend wordt dat ledereen zijn huiswerkopdrachten dan heeft uitgevoerd.

Aan het begin van elke volgende zitting vinden huiswexk (na-) besprekingen plaats, wasin

- elke client afzonderlijk wordt gevraagd of hij zijn huiswerkopdrachten heeft uitgevoerd, hoe dat verliep en of hij zelf tevreden is met zign verrichtingen. 
- soclale bekrachtiging wordt toegediend aan clibnten die hun huiswerkopdrachten hebben uitgevoerd.

- teleurgesteld gereageerd wordt op clienten die dit niet deden, terwijl deze clienten ex nogmaals op gewezen worden dat huiswerk een noodzakelijk onderdeel is wan het behandelingsprogramma.

- faalervaringen worden, via een aantekening op de flap-over, vastgehouden met het doel direct na de huiswerk-ronde een reconstruexend rollenspel op te zetten ('We zullen dat zo dadelijk nog eens spelen en kijken wat je had kumen doen on het anders te laten verlopen").

- positieve rapportages ('het ging prima') nader worden afgecheckt ('hoe ging het dan? wat deed je precies?'), warbij de therapeuten de toelichting van de cliënt war mogelijk vertalen in de leerpunten en bekrachtigen ("dat was dus leerpunt ...., ultstekend:").

- de clienten tevens de gelegenheid krijgen recente ervaringen met de doelvaardigheid, welke niet tot de huiswerkopdrachten behoorden, in te brengen. ook deze rappoxtages kunnen leiden hetzij tot bekrachtiging hetzif tot de beslissing reconstruexend rollenspel te laten volgen.

De huiswerk (voox-) besprekingen aan het eind van de tweede en dende zitting kunner kort zijn, aangezien elke cliënt aan het eind van zijn anticiperend rallenspel reeds huiswerkopdrachten kreeg. Deze opdrachten worden voor elke cliënt afzonderlijk nog eens herhaald, bij vookkeur door de client zelf ("Wat ga jij ook al weer doen, Jannie?"): war nodig worden de notities op de flap-over en in de hulswerkboekjes aangewuld en iedereen wordt opnieuw succes toegewenst.

De huiswerkbespreking aan het eind van de laatste zitting meant wat weex tujd in beslag. Naast de concrete opdrachten, voortwloelend uit het anticiperend rollenspe1, krijgt elke client durzamer opdrachten en tips mee, en wel.

- oparachten om de toepassing van het geleerde voort te zetten - suggesties tot zelf-bekrachtlging ('... dan trakteer je jezelf maar eens. Wat wil je ermee verdienen?'). liefst ook bedekte zelfbekrachtiging ('en wat denk je dan bij jezelf als het gelukt is?').

- specilale tips toegesneden op de individuele client, voor zover deze voortvioelen uit de ervaringen die tijdens de groepsbijeenkomisten 
ziji opgedar ("Hans, jij weet het, jij moet dus vooral niet vergeten om ....".). Dok de clienten worden ingeschakeld bij het aanreiken van tips.

Indien mogelijk worden clienter die speciale banden ontwikkela hebben met elkaar of in elkaars nabijheld verblijwen (bijvoorbeeld in dezelfde buurt) uitgenodigd contact te blijven houden on ervaringen uit te wisselen of elkaar te raadplegen.

\subsubsection{Programma-overzicht}

In de 4 groepsbijeenkomsten komen de diverse programa-onderdelen als volgt aan de orde:

le zitting: introductie

imiterend rollenspel

(reconstruerend rollenspel)

huiswerk-voorbespreking

2e zitting: huiswerk-nabespreking

(reconstruerend rollenspel)

imlterend rollenspel

anticiperend rollenspel

huiswerk-voorbespreking

3e zitting: huiswerk-nabespreking

(reconstruerend rollenspel)

anticiperend rollenspel)

hul swerk-voorbespreking

4e zitting: huiswerk-nabespreking

(reconstruerend rollenspel)

antlclperend rollenspel

huiswerk-eindbespreking.

zle ook het als bijlage 2 opgenomen 'beknopt araaiboek'. 


\subsection{Aanvullende richtijinen en toelichtingen}

Een aantal zaken van wisselende aard die in de programa-beschxijving niet of zonder toelichting aan de orde zijn geweest worden hieronder besproker en verduidelijkt.

\section{2 .1 Twee therapeuten}

De aanwezigheid van twee therapeuten is met name noodzakelijk vanwege de rollenspel-activiteiten. De therapent die de 'regie' heeft van een rollenspel, heeft al zijn aandacht nodig voor datgene wat zich op en bij het speelvlak afspeelt. De tweede therapeut, in die positie tot nu toe steeds aangeduid als cotherapeut, kan tijdelijk als model of antagonist worden ingeschakeld. Bij voorkeur is hilj echter bij de groep, warr hij wakt over de toeschouwende en de in de groep (na een functie in het rollenspel vervuld te hebben) terugkerende cliënten, en modelgedrag vertoont met betrekking tot bekrachtiging-door-toeschouwers. In principe hebben beide therapeuten dezelfde taak, warbif zij afwisselend de regie op zich nemen.

De protagonist in het rollenspel kan de thexapeut aanwilyzen als degene die het meest in aanmerking komt om de antagonlstenrol te vervullen, of de therapeut expliciet vragen om te modelen. In dat geval zal de therapeut op het verzoek ingaan en zal de cotherapeut $z$ ich naar de rand van het speelvilak begeven en de plats van de therapeut innemen.

\section{2 .2 Directiviteit en tempo}

De therapeuten treden, met een zekere vanzelfsprekendheid, directef an woortwacend op. De beschikbare tijd worat zoveel. mogelijk benut voor rollenspelen. Niet alleen efficiency-overwegingen en de korte duux van de groep spelen hier een rol, doch ook de ervaring dat directivitelt en vaart spanningsreducerend werken en groepsprocessen geen kans krijgen te gaan domineren. Richt men een vraag tot de groep, dan zal. vaak de spanning bij de deelnemers toenemen of zullen bepaalde groeps- 
leden gaan domineren. Richt men zich steeds tot een deelnemer, dan zal dit niet het geval zijn en kan men bovendien de attentie van de deelnemers hoog houden. Elke deelnemer leert immers dat hij op elk moment aangesproken kan worden on bijyoorbeeld feedback te geven: mocht desondanks zljn aandacht verslappen, dan kan de therapeut hem onmiddellijk aanspreken.

Vooral bij huiswerkrapportages en bif beschrljuingen van oefensituaties hebben aliënten vaak de nelging breedsprakig te zijn. De therapeut zal het tempo ex in kunnem houden door het gexapporteerde snel in (nieuwe) oefensituaties te vertalen.

\section{2 .3 Het speelvilak}

Gedragsofeningen vinden niet plats in het hier-er-nu van de groep. Dat zou groepsprocesser. mobiliseren en de spanning onnodig doen toenemen. Alle gedragsoefeningen spelen zich af in rollensyelen, die 'binmengehaalde buitensituaties" representeren, gesttueerd op een daartoe gereserveerd deel van de beschikbare ruimte: het "speelvlak". De therapeuten accentueren het onderscheld tussen het hier-en-nu van de groep en het daar-en-dan van rodienspelen

- door zich niet op het speelvlak te begeven tijdens het spel

- door te zorgen dat zowel de protagonist als hijzelf zich bij vaor-en nabeschouwingen (instructies, feedback) bevinden op de grens van het speelvlak

- door miet toe te staan dat er gecommiceerd wordt tussen mensen die zich op het speelvlak bevinden en mensen daarbuiten. De enige uitzondexing daarop is de therapeut zelf als hij vanaf de rand van het gpelvlak het spel stopt en de spelers vraagt "erult te komen"

- door cluenten te instrueren in hun rol te blijwen.

\subsubsection{Negatieve zelf-beweringen van clienten}

Cliënten reageren regelmatig, als zij worden uitgenodigd tot een gearagsoefening of om model te staan, met uitlatingen in de trant van "dat kan ik toch niet" of "dat lukt mij nooit' "Dexgelijke negatieve zelfbewextngen worden onmiddellijk verbaal gedisconfirmeerd: "Oh, jawell: 
Dat kun jij wel, let maar eens op" liefst, na de gearagsoefening, gewolgd door de conclusie: "zie je nou wel dat je dat kunt".

Negatieve zelfbeweringen komen ook, in indixecter vorm, voor bij protagonisten die hun geslaagde rollenspelverrichtingen trachten af te schuiven op (meestal) de meegaandheid van de antagonist: 'Nu ging het wel goed, max hij heeft het me ook niet zo moelijlk gemaakt'. Vaak is de antagonist de eerste die hierop corrigerend reageert: "Ik wou het je helemaal niet makkelijkk maken; dat kwam door jou, ondat jij $z 0 . .$. deed'.

Doet de antagonist dat niet, dan kan de therapeut hem daarom vragen of zelf corrigerende opmerkingen in deze zim platsen. Is de bewering van de pratagonist reeel, dan dient de gedragsoefening herhaald te worden met aanvullende instructies aan de antagonist, liefst conform de aanwijzingen van de protagonist.

\section{2 .5 Moeilijke clienten}

Hoe met "weerstand' tegen rollenspel wordt omgegaan is reeds enigszins beschreven. De client kan zijn pogingen or rollenspel te vermijden ook gieten in de vorm van 'dat kan ik wel, dat hoef ik niet te oefenen'. De therapeut zal dan niet pogen de cllënt ervan te overtuigen dat higl 'het niet kan'; eerder wordt de cliënt bevestigd in zijn oordeel en toch in het rollenspel betrokken onder het mom van modeling: "Dat is fijn, Kees. Dan kun jil mee voordoen voor de anderen hoe ze de leerpunten kunnen toepasser. Laten we maar eens ...." (start rollenspel). Vermijdingsgedrag krijgt ook wel eens de vorm van bagatelliseren of diskwalificeren van de leerpunten: "Ik vind het onzin on date zo te doen". In zo"n geval worden geén (verbale) pogingen gedaan de client te overtulgen van de zin van de leexpunten, maar wordt de clilent uitgenodsgl 'het gewoon eens te doen, dan weet je hoe het is als je het doet; dan kun je daarna beslissen, of Je het wilt gebruiken. Kom maar'. De client makt zijn diskwalificatie na het rollenspel steeds ongedaan: 'Ja, het heeft toch wel woordelen, als je...'. 


\section{2 .6 Mezen yan modellen}

B.j het kiezen van modellen spelen voor de therapeut de volgende overwegingen mee:

- het modelen van het gedrag door mede-clienten is woox hen een extra gelegenheid tot gedragsoefening

- het modelen door een mede-cliënt verdient bovendien de voorkeur boven het modelen door een (co) therapeut, vanwege de grotere onderlinge gelijkenis tussen cliënten

- de protagonist zal zich tot het ene groepslid meer aangetrokken voelen dan tot het andere, en $z a l$ de een meer bewonderen lstatus of bedrevenheld toeschrijwen) dan de ander

- het te modelen gedrag zal zeex waarschljnlijk meer adequat zijn en in hogere mate een representatie van de leerpunten inhouden als de cotherapeut als model optreedt.

De twee eerste overwegingen vragen om het kiezen van een client als model, en de therapeut zal zich bijdie keuze op grond van de derde overweging mede laten leiden door de voorkeur (en) van zijn protagonist. Als hij echter van mening is dat de aangedragen situatie dermate moeilijk of bedreigend is dat nauwelijks verwacht kan worden dat medecliënten erin zullen slagen adequaat model-gedrag te vertonen, zal de therapeut ziln cotherapeuten als model inschakelen.

Het is belangrijk dat de thexapeut zich realiseert dat een ciliënt die als model. wordt ingeschakeld, op het moment dat hij $z$ ijn modelgedrag stelt, zelf een gedragsoefeming onderneent.

Hoewel het felt, dat deze client op dat moment geen protagonist is, niet toelaat uitwoexig op zijn verrlchtingen in te gaan (er wordt b. $v$. géen shaping toegepast op het model; dat leidt tot verwarring In thet rollenspel), worden wel de bekrachtigings-principes toegepast: door de pratagonist uit te nodigen an te geven welke gedragingen hij van het model wil overnemen, valt het model selectieve positieve bekrachtiging tem deel voor adequate gearagimgen. 


\subsubsection{Bekrachtigers en bekrachtigende instanties}

Als bekrachtigers worden vooral verbale goedkeuxingen " prima" "goed 20'. 'uitstekend", etc.) gebruikt. Ook non-verbale saciale bekrachtigets zoals een schouderklop, een applausje, of een aulm-op gebaar en materiele bekrachtigers zoals een kop koffie of een sigaret worden verstrekt. De bekrachtiger wordt steeds gekoppeld aan welomschreven responsen. Gepoogd wordt de kwantiteit en/of kwaliteit van de bekrachtiger in overeensteming te doen zijn met de verrichtingen van de protagonist, warbij rekening wordt gehouden met diens mogelijkheden en inspanningen.

Bekrachtigende instanties zijn primaix de therapeuten. Deze schakelen echter voortđurend de cliënten in als bekrachtigende instanties, uitgaande van de veronderstelling dat het oordeel van de leden var de eigen sociale graep woor de pratagonist zwaar zall wegen. Dit inschakelen geschiedt op zodanige wijze dat zo mogelijk alleen positieve bekrachtiging van gewenst gedrag plaatsvindt ('Marla, welke leerpunten heb jij Hans zien gebruiken? Hoe vind je dat?"). Zodra lemand de geboden gelegenheld gebruikt an de protagonist negatieve feedback te verschaffen c.q. te wijzen op zijn falen, vangt de therapeut de opmerking soepel op door deze te herformuleren in een witnodiging aan de protagonist 'het nog eens te doen, maar nu met ....' (shaping").

Het feit dat niet de cliënt bekrachtigd wordt (ongericht), maar zijn concrete gedragingen, voor zover die aan het doelgedrag beantwoorden, -men zou kumen zeggen dat de cliënt bekrachtigers moet "verdienen"heeft als consequentie dat elke client in voldoenöe mate de kans atent te krijgen de doelgedragingen te stellen. De therapeuten zorgen ar dan ook voor dat de afzonderlijke clienten een evenredig aantal beurten kxijgen in het rollenspel, als protagonist èn als model.

\subsubsection{Bekrachtiging en weerstand tegen ultaoving}

Gedrag dat aan continue bekrachtiging blootstaat, dooft relatief snel. uit bij uitblijven van die bekrachtiging, terwijl gedrag dat onderbroken bekrachtigdi wordt, meer resistent is tegen uitdoving. 
De duuxamheld van het geleerde gedrag zal na de therapie groter zijn

- naxmate de toepasing van het geleerde gedrag voor de (ex-) client intrinslex bekrachtigend is, d. w. z. dat de gedragingen zelf de cliernt voldoening schenken:

- als de toepassing van het geleerde gedrag gepaard gat met onderbroken bekrachtiging.

Hoewel toepassing van de vaardigheld na de theraple in veel gevallen zonder specifleke voorzieningen of afspraken aan onderbroken bem krachtigling bloot zal staan, bijwoorbeeld omat de (ex-) client zo nu en dan door het stellen van het doelgedrag zijn zin krijgt, spanningsreductie ervart, of (zelfs) soclale bekrachtiging ondervindt uit zijn ongeving, wordt toch getracht de roortzetting van toepassing van het geleerde te bevorderen "door

- reeds tijdens de theraple over te schakelen van een continu naar een onderbroken bekrachtigingsschema: in de laatste twee zittingen worden slechts "nileuwe prestaties" van de cliënt bekrachtigd, verrichtingen die reeds eerder gesteld en bekrachtigd werden krijgen minder aandacht.

- de cliënten er regelmatig op te wijzen dat toepassing van de doelvaardigheid niet steeds betekent 'dat je je zin krijgt', maar 'dat jij het dan in elk geval goed gedaan hebt'.

- tijdens het rollenspel aan te sturen op realisering wan het doelgedrag door de protagonist op een wijze die hemzelf kennelijk voldoening vers ghaft.

- met de clienten afspraken te maken omtrent zelfbekrachtiging. De vraag 'hoe ga je jezelf belonen?' lokt overigens vaak het antwoord uit: 'dat hoef $1 k$ nitet, want $1 k$ ben al bly als het me gelukt is' (= intrinsieke bekrachtiging:.

- war nogelijk clienten uit te nodigen ondexling contact te houden waarbly erop gegokt wordt dat deze cliënten voor elkaar bekrachtigende instanties zijin of worden.

- waar mogelijk professionele werkers die in voortgezet contact met de client staan (verwifzers) ult te nodigen de voortgezette toepassing wan geleexde gedragspatronen te bekrachtigen. 


\subsubsection{Beeindiging var het roldenspel}

Het spel wordt bij voorkeur beelndigd direct nadat de leerpunten zijn ultgevoerd c.q. de vaardigheid gepasseerd is. Dit geldt zowel roor het spel van een model als voor dat wan een protagonist in alde typen rollenspelen.

Een eerste reden daartoe is dat responsultkomsten bij toepassing in eigen levenssituaties nauwelijks voorspelbaar zijn en 'doorspelen" mogelijk valse illusies met betrekking tot die uitkonsten kan wekken. Daarnaast geldt dat doorspelen meestal betekent dat er wordt overgegarn tot een interpersoonlijke litwisseling die niet tot het kadex van de doelvaardigheld behoort.

Protagonisten kunnen erg teleurgesteld reageren als het spel wordt gekapt op het moment dat de effectiviteit van hun gedrag moet blijken ('Nou weet ik nog niet of $z$ meegaat'). De boodschap van de therapeut hierop is steevast: "Dat kunnen we hier ook niet weten. We weten wel hoe jij het hebt aangepakt', waarop bespreking volgt van de verrichtingen van de protagonist. Belangrijke informatie, die de protagonist na afloop van het rollenspel niet onthouden mag worden, is hoe hij (zijn verrichtingen) door de antagonist is/zijn erwaren.

\section{2 .10 Bedekte gedragingen}

Alle vaaraigheden, persoonlijke en interpersoonlijke, zijn gedragssequenten die deels bedekt (covert) en deels observeerbaar (overt) zijm. Concretisering van een leerpunt als "ga na wat je prettig vindt van de ander", het eerste leexpunt van de vaaraigheid "uiten van genegenhelia en waardering', zal voor een klein deel observeerbar zijn (kjukt, denkt maar voor het grootste deel een niet-warneembare 'binnenspraak' omvatten. In elk type xollemspel worden de coverte gedragingen aanvankelijk overt ('denk maar hardop') en latex in hurn natuurlijke, coverte uitarukkingsvorm beoefend. Voor de duldelijkheld kan men en plek blinen het speelvlak afbakenen met behulp van een krijtcirkel of matje: als de protagonist vanuit die positie spreekt dan geldt het gesprokene als 'denktal', die de antagonist niet hoort en warbilj de tlja stil staat. 


\subsubsection{Overlge "groepstechnieken"}

De meer met 'rollenspel" vertrouwde lezer zal waarschijniljk een antal technieken genist hebben, zoals terzijdes, dubbelen, spiegelen, e.d. (zile o. a. Me1110 en Goedhart, 1980).

Dat wil hiet zeggen dat ze impliclet zijn gebleven, noch dat de therapeuten zich vrlj achten deze technieken toe te passen. Ze horen echtex niet in deze vaardigheidstherapieën thuis. Nand Cuvelier (1976) wijst terecht op de noodzalk een duidelijk onderschedd te maken tussen de diverse spelvormen en deze te bezien en toe te passen in het kader van de "dramavorm" die wordt gehanteerd. Cuvelier noemt als dramavormen het psychodrama, het interactiedrama, het socioarama, de roltraining en de rolexploratie. Het rollenspel, zoals het in dit artikel beschreven wordt, dient men te zien als uitsluitend een toepassingsworm van wat cuvelier "roltraining" noemt.

Overigens is Goldgtein (1981) het er kemnelijk met Cuvelier over eens dat de techniek van rolwisseling, warbij protagonist en antagonist elkaars rol overnemen, van nut kan zijn in een roltraining en wel in die gevallen warin de protagonist weinig zicht blijkt te hebben op de situatie van de antagonist.

\subsection{Het programma als uitvoeringsvorm van Goldstein."s SLT}

De wijze waarop de hoofdcomponenten van modeling, gedragsoefening, bekrachtiging en transfer-training in het the capieprogramma worden aangewend, zal voor een groot deel evident zijn, voor een ander deel is dit impliciet gebleven.

Het 1 wooral de complexe verwevenheid van de componenten in de diverse programa-onderdelen die het wenselijk maakt de theraple nog eens "door te lichten' aan de hand van de vier hoofdcomponenten. In het nu volgende wordt beschreven op welke momenten en op welke wijze de afzonderlijke leexprincipes aangewend worden. 


\section{3 .1 Modeling}

In de groepsbijeenkomsten indt modeling plaats

- met behulp van de tevoren op video opgenomen scènes De video-modeling vindt plaats tijdens de eerste twee groepsbijeenkomsten, steeds in het kader van het opstarten van initerend rollenspell, en incidenteel in de modeling-fase van een reconstruerend of anticiperend rollenspel mits de door de protagonist ingebrachte situatie veel elementen bevat die identiek zijn aan een der videoscènes.

- door de therapeuten en de groepsleden in het kader van reconstruarend en anticiperend rollenspel, op momenten dat zij model staan voor ean protagonist.

- door protagonisten in elk type rollenspel. Elke gedragsoefening fungeert immers tevens als modeling voor de toeschouwende medecliënten.

Een kleine rekenson leert dat in een groep met 6 deelnemers, waarin elke client tweemal de rolvan protagonist vervult in imiterend en driemal in anticlperend rollenspel, elke client naast de videomodellen minimaal 40 live-modellen krijgt aangeboden.

ook buiten de therapiesituatie vindt modeling plats. De cliënten zullen herhaaldelijk geconfronteerd worden met gedragingen van anderen die in meerdere of mindere mate overeenkomen met of juist afwijken van de vaaraigheid/de leerpunten die zij zich trachten eigen te maken. Dit wordt niet genegeerd, maar ten voordele aangewend in het leerproces. De eerste groepsiltting heeft als vaste huiswerkopdracht: 'goed op te letten hoe andlere mensen.... doen. Vaak zul je zien dat merisen onze leerpunten toepassen, vaak ook dat ze dat niet doen".

\section{3 .2 Gedragsoefening}

Gedragsoefening windt plaats

- door de protagonist in elk type rollenspel.

- door cliënten, die als model optreden in reconstruerend en anticiperend rollenspel. De opdracht aan het model is van dien aard, dat optimale condities aanwezig zijn voor 'commitment', en improvisatie. 
- door clienten tijaens wilvoering van huiswerkopdrachten.

In de bovenbeschreven groep krijgt elke client gelegenheid tot minimal

11 gedragsoefeningen: 5-mal als protagonist, 3-maal als model en 3-maal bulten de groep (huiswerk).

\section{3 .3 Bekrachtiging}

Positueve bekrachtiging van het aan te leven gedrag indt plaats

- tijdens de video-modeling: in de scènes-met-leerpunten krijgt de gebeurtenls waarin de hoofdrolspeler de leerpunten toepast een voor deze hoofdrolspeler meer gewerst verloop. Bovendien stelt de deskundige die de scèmes inleidt dat "het goed is" als mensen zich aan deze leerpunten houden.

- In de modeling-fase van het rollenspel: aandacht voor die gedragingen van de als model optredende client de beantwoorden aan de leexpunten en de moite wardzijn om 'over te nemen'.

- In de gedragsoefeningtase van elk rollenspel: gedragtingen van de protagonlst die passen in het gestelde leerdoel worden bekrachtigers.

\subsubsection{Transfer-training}

De transfer-training beoogt te garandexen dat de doelvaardigheid niet slechts binnen de thexaple-situatie gesteld zal worden maar ook daarbuiten, en niet slechts voor de duur van de therapie maar ook daarna. Goldstein (1979) maakt in dit verband een onderscheid tussen 'transfer" (verplaatsing) en 'maintenance" (handhaving) van gedragsmodificatie. In alle fasen wan de theraple wordt met de noodzaak van transifex rekening gehouden:

a. On te voorkonen dat de theraple-situatie (ruinte, groep, therapeuten) voor de cliënt de discriminatieve stimulus wordt die het stellen van het doelgedrag uitlokt

- toont de video-modeling het doelgedrag in herkenbare leefsituaties

- vinden alle gedragsoefeningen plaats in (weliswaar imaginalr)

"binnengehalde buitensituaties"

- worden in het reconstruerend en anticiperend rollenspel specifieke stimulus-situaties ult het dagelijks leven van de cliënten binnen- 
gehald en met zorg aangekleed

- worat de protagonist in het anticiperend rollenspel gedegen voorbereid op het toepassen van de doelvaardigheid in een elgen leefsituatie, teneinde de kans op succes bij toepassing in aie situatie te vergroten

- worden huiswerkopdrachten gegeven die het stellen van de doelvaardigheld buiten de therapiegroep beogen

- stellen de therapeuten herhaldelijk expliciet at het aan te leren gedrag niet bedoeld is voor de thexapiesituatie maar juist voor toepassing in de eigen leefongeving.

b. On te voorkomen dat eén of enkele buiten-situaties de rol van discriminatieve stimulus krijgen, wordt "stimulusgeneralisatie" bevorderd:

- de video-modeling toont de doelvamaligheid in arie zeer uiteenlopende stimulussituaties (een gezins-" eem werk- en een pubiloke situatieh, waarbij bovendien naar status, leeftija, sexe, e.d. verschillende 'tegenspelers' aanwezig zijn

- tijdens rollenspel zien de toeschouwende ollenten de doelvaardigheid gesitueerd in een breed scala van stimulussituaties

- de therapeuten waken exvoor dat elke client meerdere levenssituaties (en niet steeds ên en dezelfde) inbrengt

- de therapeuten bewaken tevens dat elke cliënt verschillende antagonisten tegenover zich krijgt.

- de protagonist ervart in het reconstruerend rollenspel dat hij de vaardigheid in de doox hem ingebrachte situatie wel degelljk kan toepassen (ook al lukte hem dat aanvankelijk niet), waarmee deze stimulussituatie (stimulusklasse) als aiscriminatieve stimulug voor het stellen van de vaardigheid behouden blijft

- de therapeuten waken er bij de huiswerktoewijzing voor dat elke cliënt meerdere an wel verschiliende leefsituaties klest

- de thexapeuten stellen herhaldelijk expliciet dat de dolvararigheld zilch leent voor toepassing in vele leefsituaties.

c. On te vookknen dat het betreffende gedrag na afloop van de therapie ultdooft door het uitblijven van bekrachtiging worden een aantal maatregelen genomen (zie 5.2.8) die de kans vergroten dat uitvoering van het gedrag intrinsleke bekrachtiging en onderbroken extrinsieke bekrachtiging oplevert. 
Zoals gesteld in 2.3 en 4.1 dilenen vaardigheidstherapieën gericht te zijn op het creẻren van conditles waaronder clienten 'vaardiger' worden: bruikbare gedragspatronen tot hur beschikking krijgen, realistische verwachtingen ontwikkelen ontrent de gebruikswaarde (effectiviteit) van deze gedragspatroneri en eveneens realistische verwachtingen ontwikkelen omtrent de eigen competentie tot ultvoering van dat gedrag. Responsinformatie en responsultkomstinformatie worden aangereikt in modelingprocedures (zie 4. en 5.3.1) en aangevuld en/of gecorrigeerd in client's gedragsoefeningen, waarin gebrekkige en/of foutieve informatie-verwerking aan het licht kan treden.

\subsubsection{Nadruk op competentle-verwachtingen}

Hoewel de beschikbaarheid van respons- en responsultkomstinformatie een voorwarde is voor adequate uitvoering van een respons, is daadwerkelijke gedragsverandering vooral afhankelijk van de ontwikkeling van het geloof tot uitvoering van bepaalde gedragspatxonen in staat te zijn \{zie 2.3). De persoonlijke competentie-verwachting bepaalt niet alleen of een individu een poging onderneemt tot uitwoering van de interpersoonlijke activitelt en hoeveel energie hij in die poging investeert, doch bepaalt eveneens de kwaliteit van het gedrag zelf. Een geringe competentie-verwachting verhoogt de sociale angst en reduceert daardoor de kwaliteit van de verrichtingen; de Feitelljke vexrichtingen bevestigen op hun beurt weer client"s lage competentie-verwachtingen. Het is deze zichzelf in stand houdende en zichzelf versterkende wisselwerking tussen cognitles en feitelijk gedrag die in een vaaraigheidstherapie doorbroken dient te worden.

Ex diemen dan ook condities te worden gecreëerd c.q. interwenties plaats te winden, die een opwaartse splraal-beweging in deze kringloop teweegbrengen. Elike gedragsverander.ng die als een verbetering beschouwd kan worden dient aangewend te worden tot ophoging van de competentie-verwachting en elke verhoging van de competentie-verwachting dient te worden benut om meer adequaat gedrag tot stand te brengen. 
Is de competentie-verwachting eenmaal verhoogd, dan diemt meex aandacht besteed te worden aan zijn generaliteit en sterkte (of. Bandura's onderscheid: magnitude, generality en strength).

\subsubsection{Verhoging van competentie-verwachtingen}

Eet therapie-programa beoogt verhoging van competentie-verwachting door

a. Clienten te informeren over hun feitelijke competentie. Een eerste ervaring die elke cliënt opdoet bij de start van een vaaraigheidstherapie is dat hij ontdekt, dat hij enkele discrete elementen van het te leren gedragspatroon reeds beheerst. Hij hoeft als het ware somige leerpunten al niet meer te leren. Deze informatie verhoogt zijn competentie-waardering: wat anderen nog moeten lexen, heeft hij reeds in zijn mars. Dit soort ervaringen zifn niet beperkt tot de aanvang van de therapie, maar treden voortarend op. Elk model toont gedrag, waarvan de cliënt een deel reeds tot $z i j n$ gedragsrepertoilre kan rekenen. In elke instructie bij gedragsoefeningen zitten dexgelijke elementen. Bekrachtiging, zowel door therapeuten als door mede-clienten, kan in dit perspectief geherdefinieerd worden tot het aanreiken van informatie aan de client betreffende zijn competentie. Dit is vooral van belang voor cliënten die weinig oog hebben voor hun feitelljke competentie en/of sterk gepreoccupeerd zijn met hun tekorten.

Een uitstekend middel om beschikbaar gedrag te benutten als middel ter verhoging van competentie-verwachtingen, is het model-staan voor een mede-cliënt. Er is immers altijd wal jets dat de protagonist van zijn model wil overnemen.

b. BeInvloeding van verwachtingen van competentile-toename. Elke cliënt mexkt dat zijn hoofabehandelaar/verwijzer, de therapenten die de vaardigheidstherapie uitvoeren en de deskundige die de videovoorbeelden inleidt er alle vertrouwen in hebben dat hil de doelvaardigheid in 4 weken zal leren beheersen. Dat beinvloedt de verwachting van de cliënt dat hif competenter zal worden in positieve zin, en deze verwachting is met name bepalend voor de inspanningen die de client zich zal getroosten om aan gestelde eisen te voldoen. 
De verwachting yan competentie-toename wordt ook bevorderd door het tonen vam video-contrast-paren (zle 4.2.3), die demonstreren hoe een realistisch referentie-model na herkenbaar te falen toch in staat blifkt tot adeguate ultwoering van het gewenste gedragspatroon, en vervolgens door het zien van voorultgang bij medeclienten.

c. Intensieve begeleiding van gedragsoefeningen.

Terwly1 verhoogde competentie-verwachtingen en een verhoogde berelaheld tot het leveren van inspanningen reeds bijdragen aan de kwallteltsverbetering van het gedrag (in rollenspel) vindt aanvankelijke toepassing van dat gedrag steeds plaats onder gedetailleerde instructles, toezeggingen van steun, aanmoedigingen. Deze intensleve coaching draagt extra bif tot meer adequate uitwoering van het beoogde gedrag. Geslaagde verxichtingen (performance accomplishments) vormen de basis bif uitstek voor een verhoging van de persoonlijke competentie-verwachting.

d. Dísconfirmatie wan negatieve zelfbeweringen.

Als een olient, verbaal of non-verbal, berichten uitzendt als zou hij toch niet in staat zijn aan gestelde eisen te voldoen, dan worden deze boodschappen verbaal ontkracht (zie 5.2.4), waarna de therapeut zorgt voox 'bewijsmateriaal' voor zijn stellingname door de cllënt te begeleiden in een gedragsoefening. Mede-cliënten worden ingeschakeld on de protagonist van zijn competentie te overtuigen. ook als de cliënt adequate verrichtingen 'teniet-doet' door deze toe te schrijven aan de begeleiding of an de meegaandheid van de antagonist wordt additioneel 'bewijsmateriaal' verzameld voor client's competentie.

e. Geleldelljke terugtrekking van begelelding. Zolang de client succeswolle uitvoering van het doelgedrag kan toeschrljven an de steun en directieven van de therapeut zullen zljn verrichtingen in onvoldoende mate bijaragen aan zijn competentieverwachting. Geleidelijk wordt er daxom in het behandelingsprogramma toegewerkt nar performances waarblj de client meer op zichzelf is aangewezen. De overgang van imiterend naar anticiperend rollenspel, en de overgang van anticiperend rollenspel naar huiswerkopdrachten zijn daarvan woorbeelden. 


\subsubsection{Generalisatie van competentie-werwachtingen}

Competentie-verwachtingen hebben een zekere mate wan specificiteit (Bandura, 1977). Zo kunnen zij betrekking hebben op welomschreven gedragingen in specifieke situaties. Het therapie-programa bevat een reeks elementen die gerlcht zijn op het generaliseren van competentieverwachtingen naar een veelheid van situaties buiten de therapie-setting. Deze elementen zijn reeds puntsgewijs besproken als elementen van transfer-training (zie 5.3.4, ad a en b). Ook de geleidelifke toepassing van de doelvaardigheid op moeilijker situaties draagt bij an de hier bedoelde generalisatie.

\subsubsection{Versterking van competentie-verwachtingen}

Zwakke competentie-verwachtingen doven snel uit door disconftrmerende ervaringen. Het therapie-progranma kent diverse matregelen ter behoud

c.q. versterking van competentie-verwachtingen:

a. het reconstruerend rollenspel als miadel om cliënten te laten ervaren dat éen mislukking nog niet onherroepelijk voortdurende mislukking betekent;

b. de ontkoppeling van responsuitkonsten en competentie. De cliënten wordt bij vooxtduring voorgehouden dat gedrag wat diet oplevert wat men ervan verwacht nog geen inadequaat gedrag hoeft te zifn (zie 5.2.9);

c. de matregelen die in 5.2 .8 zijn beschreven en gedefinieera als toewerken naar onderbroken bekrachtiging en intrinsiek bekrachtigendie uitwoeringswormen van het doelgedrag;

d. het bewerkstelligen van zoveel mogelijk oefening van de doelvaardigheld tijdens de therapie en het andringen op zoveel mogelijk toepassing ervan in bultensituaties look na afloop van het therapleprogramma). Herhalde succesvolle toepassing zal de competentieverwachting resistenter maken tegen een enkele erwaring, die in strijd is met de competentie-verwachting. 


\section{DE ONTWIKKELING VAN VAAPDIGHEIDSMETERS (SKIMS)}

In dit hoofdstuk worden de constructie en het onderzoek naar de betroubbarhedd en validiteit beschreven van een serle meetinstrumenten voor interpersoonlijke vaardigheden: Skims (skillmeters). Aanleiding tot het ontwikkelen van deze batterij is geweest het ontbreken van geschikte instrumenten on de effecten van de ontwikkelde vaardigheidstherapieen op (on) vaardigheid op efficiente wijze te meten.

De keuze van de 9 vaardigheden is gebaseerd op een onderzoek naar interpexsoonlijke gedragsexcessen en -tekorten bij een RIAGG-cliềntenpopulatie (hoofdstuk 3). In dat onderzoek is gebruik gemakkt van een Nederlandse versie van de Interpersonal checklist (ICL), gebaseera op de roos van Leary (Leary, 1957; LaForge en Suczek, 1955; Diekstra. 1972). Deze vragenlijst heeft echter niet de pretentie sociale vaardigheden te metien.

Weliswax und er in het Neder landse talgebied meerdere vragenlijsten in omloop ter bepaling van assertiviteit en/of sociale vaardigheder, zoals de Assertiviteitsschaal van Rathus (1973), de Assertiviteitslijst wan Wolpe en Lazarus (1966) en de pximulaschaal van Schouten (1977), doch deze zijn niet of nauwelijks gevalldererd, noch meten zij specifleke interpersoonlijke competenties (responsklassen of varalgheden). In 2 nlewwe lijsten, de Assertivitejtsschaal van Brinkman (Bxinkman en Hox, 1977; Brinkman, 1977) en de Schaal voor Intexpersoonlijk Gedrag (Arrindell, De Groot en Walburg, 1980) wordt wel. onderscheid gemaakt tussen diverse responsklassen, die bovendien voor een deel overeenkomen met de bovengenoemde 9 vaardigheden. Aan de 
normering en validering van deze schalen wordt gewerkt. Ex is overwogen (delen van) deze lijsten aan te wenden ten behoeve van de effectstudies bij Goldsteintherapieên. Ervaxingen met de doelgroep, clienten uit lagere sociaal-economische klassen, hebben echter meemalen ultgewezen dat deze mensen grote moeite hebben met en begeleiding en uitleg nodig hebben bij invulling van vragenlijsten warin uitspraken en antwoordcategorleên voorkonen van het type: "Ienand, die al eerder van mil heeft geleend en zelden of noolt iets teruggeeft, weiger ik met opgaaf van redenen verder lets te lenen', geheel van toepassing ...., etc. (AsS) en 'Er op aandringen dat lemand zijn/haar aandeel levext in een gemeenschappelijke taak' (SIG).

Besloten is dan ook een serie "vaardigheidsmeters" te ontwikkelen, afgestemc op het pakket opgenomen interpersoonlijke waardigheden en op het taalgebruik van de doelgroep.

\subsection{De constructie}

Bij de opstelling van de Skin-items is als volgt te werk gregaan. Per vaardigheid zijn 50 à 60 'klachten' verzameld door aan \pm 25 cliënten, aangemeld voor deelname aan een specifieke vaardigheidstherapie, te vragen: "U gaat meedoen aan een groep om te leren .... (naam van de vaardigheid). Wat is uw probleem met ....; wat vindt u daar moeilijik aan?'. Ten hoogste drie uitspraken per cliënt zijn genoteerd, in zo letterlijk mogelijke bewoordingen.

\section{1 .1 Item-constructie}

Uit de aldus vexzamelde uitspraken is een selectie gemakt, van meerdexe malen gedane uitspraken is er steeds één gekozen; individuof situatie-specifieke uitspraken zijn buiten de selectie gehouden. Geinspireerd door Shapixo's constructiewdjze van "Personal Questionnaires" (Shapixo, 1961) zijn van elk van deze 'ziek"-u1tspraken een 'Malf-betex'- en een 'beter'-uitspraak afgeleid. zo zijn van de (ziek-) uitspraak. 'Ik weet me nooit een houding te geven' de uitspraken 
"IK weet me sois geen houding te geven" (half-beter) en "Ik weet me meestal wel een houding te geven' (beter) afgeleid, die verwolgens in: ến drie-keuze-1tem in de betreffende skim zijn opgenomen:

$$
\begin{aligned}
& \text { Ik weet me } 0 \text { roolt een houding te geven } \\
& 0 \text { soms geen houding te geven } \\
& 0 \text { meestal wel een houding te geven. }
\end{aligned}
$$

Bij de diverse items is de "ziek-uitspraak" een aantal malen als eexste, dan weer als derde alternatief geplaatst.

Deze werkwijze is gevolgd blj elk van de 9 interpersoonlijke vaardigheden. De 9 voor lopige Skims bevatten elk 14 tot 22 drie-keuze-items, die betrekking hebben op meerdere modaliteiten (gedrag, cognities, emoties).

\section{1 .2 Eactor-analyses}

De aldus geconstrueerde 9 voor lopige skims zijn afgenomen bij groepen veertlgjarlge Maastrichtse mannen. Principale factoren-analyses over de 9 item-lifsten afzonderlijk levert in 5 gevallen eển factor op met een elgenwaarde grotex dan 1.0, in 4 gevallen twee factoren (zie

\begin{tabular}{|c|c|c|c|c|c|c|c|c|c|}
\hline & \multicolumn{9}{|c|}{ voor lopige Skins } \\
\hline & $\mathbb{I}$ & 2 & 3 & 4 & 5 & 6 & 7 & B. & 9 \\
\hline antial. It tays & 17 & 14 & 16 & 18 & 22 & 14 & 14 & 21 & 19 \\
\hline arintal respondenten & 156 & 156 & 156 & 156 & 156 & 226 & 226 & 156 & 156 \\
\hline $\begin{array}{l}\text { antal lactoron met } \\
\text { digentarde } 1.0\end{array}$ & $\mathbb{1}$ & 2 & 1 & 2 & 2 & 1 & 1 & 2 & $₫$ \\
\hline 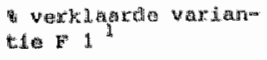 & 45.3 & 26.4 & 34.4 & 20.0 & 16.4 & 42.7 & 38.7 & 26.2 & 31.7 \\
\hline 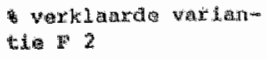 & so & 12,9 & - & 12.8 & 14,5 & - & - & 13.3 & - \\
\hline
\end{tabular}
tabel 6.1). In deze 4 gevalien is varimax rotatie uitgevoerd.

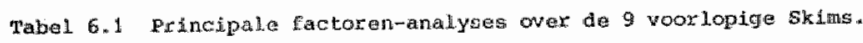

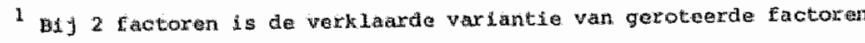
werergegreven. 
De eerstie factor blijkt bij alle 9 skims gekenmerk te worden door hoge ladingen van items die de mate uitarukken waxin men zich (niet) in staat voelt, het (niet) moeilijk vindt, (niet) bang of onzeker is, het (niet) vermijat de betreffende interpersoonlijke activiteit wit te voeren. In die gewallen waar een tweede factor is gevonden (luisteran, reageren op kwaacheid, aiten van kwaadheld, opkomen voor je mening) blijkt het steeds te gaan on uitspraken over de mate waarin men al of niet tot adequate uitwoering van de intexpersoonlijke activiteit geMinderd wordt door irritatie, ongeduld of (onbeheerste) kwadheid.

\section{$6.1 .3 \quad$ A- en B-Skims}

Besloten is op grond van deze data de definitieve Skims wast te stellen: 9 A-Skims (de subassertiviteits-/onvaardigheidsdimensie) en 4 B-Skims (de agressieve dimensie), elk bestaande uit 5 à 7 items. Pex Skim zijn die items opgenomen die de hoogste ladingen vertonen op de betreffende factor. Het aantal items $(5,6$ of 7$)$ is afhankelijk gesteld van de relatieve homogeniteit van de ladingen (zie tabel. 6.2 ; de skims zelf zijn als bijlagen 3 en 4 opgenomen).

Tabel 6.2 Aantal 1 tems met factorladincen per skim.

\begin{tabular}{|c|c|c|c|c|c|}
\hline \multirow[b]{2}{*}{ Varof I gheden } & \multicolumn{2}{|c|}{$n-5 k d$ mas } & \multicolumn{3}{|c|}{ B-Skinis } \\
\hline & $\begin{array}{l}\text { Aarted } 1 \\
\text { items }\end{array}$ & $\begin{array}{l}\text { factos adingen } \\
\text { wan ... tot... }\end{array}$ & $\begin{array}{l}\text { Rancal } \\
\text { itens }\end{array}$ & $\begin{array}{l}\text { facto } \\
\text { van. }\end{array}$ & $\begin{array}{l}\text { ordacingera } \\
* \text { tot: } \ldots\end{array}$ \\
\hline 1. prakte natan & $\pi$ & $.77-.70$ & - & & - \\
\hline 2. Lubseren & 7 & $72=.54$ & 7 & .70 & $m=.36$ \\
\hline 3. lets bepren & 6 & $.81-.65$ & - & & $*$ \\
\hline 4. reageren op kwadhejul & 6 & $.70-.53$ & 5 & .77 & -.41 \\
\hline 5. uften van kadoda & 7 & $.74-.51$ & 7 & .69 & $=.46$ \\
\hline $\begin{array}{l}\text { 6. Wuter van genegenheld en } \\
\text { waduering }\end{array}$ & 7 & $.72-.67$ & - & & - \\
\hline $\begin{array}{l}\text { 7. reageren op genegerihadd en } \\
\text { wadratering }\end{array}$ & 6 & $.78 \times .65$ & - & & - \\
\hline 8. opkcaura vour je mending & 7 & $.69-.60$ & 6 & .76 & -.43 \\
\hline 9. tegen anderen inga an & 5 & $.72-.69$ & - & & - \\
\hline
\end{tabular}


De Skim-scores worden vastgesteld door elk item de score 0 , 1 of 2 toe te kennen, respektievelijk voor de keuze van de ziek-, de halfbeter- of de beter-ultspraak en deze itemscores te sommeren.

Een factor-analyse over de 13 skim-scores van 226 veertigjarige Maastichtse mannen bevestigt de aanwezigheld van twee typen (on-) wardigheld in de battexil: twee factoren met eigenwarden groter dan 1.0 verklaren respektievelijk 56.8 en 11.78 van de variantie. Na vaximax-rotatie wordt de eerste factor gekennerkt door hoge ladingen wan de 9 A-Skims (tussen .86 en .62) en lagexe ladingen van de 4 B-Skims (.43 tot .1.2), terwijl de tweede factor hoge ladingen van de B-Skims, van .82 tot .53, en lage ladingen van 4 -Skims kent (tussen .41 en .09).

\subsection{Betrouwbaarheid en stabiliteit}

Van elk van de 13 definitleve skims, afgenomen bij de eerdergenoemde veertigjarigen, is de betrouwbaarheid bepaald in de zin van een coëfflciënt van item-consistentie: Cronbach's alpha. Deze blijkt te varierren van .73 tot .89 (zie tabel 6.3).

Tabed 6.3 Interne consiotenties (Cxondich"s alpha) en test-hertest-correlaties (Peason) met een interval varn 6 a 7 manden.

\begin{tabular}{|c|c|c|c|c|c|c|}
\hline Skims & $\mathbf{N}$ & $\begin{array}{l}\text { Int: cons. } \\
(\text { ald pha })\end{array}$ & $\mathbf{N}$ & 10 meting & $\begin{array}{l}\text { glden } \\
\text { ge meting }\end{array}$ & $\begin{array}{l}\text { test-hextest } \\
\text { corr. (Pearson) }\end{array}$ \\
\hline $1 \mathrm{~A}$ & 1156 & .849 & 115 & 11.2 & 11.1 & .83 \\
\hline $2 A$ & 156 & . B A & 115 & 12.0 & 11.9 & . \\
\hline $2 \mathrm{~B}$ & 156 & .73 & 115 & 10.6 & 10.5 & .810 \\
\hline $3 \mathrm{~A}$ & 150 & .63 & 115 & 9.6 & 9.6 & .70 \\
\hline $4 A$ & 155 & .79 & 115 & 4.5 & 0.6 & $.7 B$ \\
\hline 413 & 156 & .73 & 115 & 6.3 & 6.6 & .60 \\
\hline $5 A$ & 156 & .79 & 115 & 9. 4. & 8.7 & .76 \\
\hline 54 & If 56 & . BilO & 115 & 9.9 & 10.4 & .77 \\
\hline $6 x$ & 226 & .86 & & & & \\
\hline $7 \mathrm{~A}$ & 226 & .87 & & & & \\
\hline $8 \mathrm{~A}$ & 156 & .34 & 111 & 10.3 & 10.7 & .80 \\
\hline 818 & 156 & .77 & 111 & 8.1 & 8.6 & .73 \\
\hline $9 \pi$ & 156 & Bat & 111 & 7.2 & 7.2 & .75 \\
\hline
\end{tabular}


In deze tabel zijn tevens test-hertest-correlaties opgenomen van 11 wan de 13 skims (de 2 ontbrekende skims zijn op het moment van de hertest voor het eerst afgenomen. Tussem de eerste en de tweade afname van de 11 skims ligt een periode vam 6 a 7 manden; daamee is in sterke mate ook de stabilitelt van het meetobject in het geding. De pearson-correlaties tussen de beide metingen liggen tussen .68 en .84. Skim $4 \mathrm{~B}$ blijkt qua betrouwbaarheid en stabiliteit de relatief zwakste schaal.

\subsection{Criteria voor de validiteit}

Betekent eer hoge skim-score daadwerkelijk dat men adequater gedrag vertoont of betekent het 'slechts' dat men subjectief meer overtuigd is van de elgen competentie? Manifesteert de "ervaren-vaardigheid" zich in voor derden warneembaar adequater gedrag? Antwoord op deze valiuiteitsvraag kan verkregen worden doox van een aantal individuen Skim-scores èn ter zake doende gedragsobservaties te verzamelen en aan elkaar te relateren. Op soortgelijke wijze zijn zelfbeschrijwingen van interpersoonlijk gedrag gevalideerd door Elsler. Miller, Hersen (1973), Burkhart, Green en Harrison (1979), Bourque en Ladouceur (1979), Rathus (1973), Galassi, Hollandsworth, Radecki, Gay, Howe en Evans (1976) Callner en Ross (1976), Williams en Ciminero (1978), Barlow, Abel, Blanchard, Bristow en Young (4977), Heimberg, Harrison, Goldberg, DesMarals en Bleu (1979), Sk111ings, Hersen, Bellack en Beckex (1978) en Cambrill en Richey (1975). Zij allen rapporteren een posttleve relatie tussen scores op een zelfrapporterende vragenlijst en geobsexveerd overt gedrag. Geen of nauwelifks enige relatie vinden daarentegen Gorecki, Dickson, Anderson en Jones (1981), Farrel1, Mariotto, Conger, Curran en Wallander (1979), Steffen en Redden (1977), Wessberg, Mariotto, conger, Farrell en Congex (1979), Alden en Cappe (1981) en Borkovec, Fleishman en Caputo (1973). Zelfbeschrijvingen omtxent interpersoonlijke competentie zijn kennelijk niet steeds in dezelfde mate 
in stat het criterlum-gedrag te voorspellen.

\section{3 .1 Cxiterium-yaliditeit van gedragsobservaties}

Somigle auteurs uiten twijfels over de validiteit van het criteriumgedrag, zoals dat in alverse studies is geoperationaliseerd. Iipinsky en Nelson (1974b) wijzen erop, dat elke vorm van observatie, warbij de proefpersoon op de hoogte is van het feit dat hij geobserveerd wordt, een vertekening van de werkelijkheid betekent door de reactieve invloed van het zich geobserveerd weten op het te observeren gedrag. Observatie van het interpersoonlijk gedrag door externe beoordelaars vindt zelden plaats in de (voor de proefpersoon) matuurlijke omgeving. Als nadelen daarvan worden vooral genoemd het tijdsintensieve karakter van een dexgelijke onderneming (Lipinsky en Nelson, 1974a) en het gebrek aan controle over diverse condities (McFall, 1977). Meestal neemt men zijn toevlucht tot observaties van gedrag in geensceneerde (laboratorium-) situaties, waarbilj een gestandaardiseerde situatie 'live' met behulp van voorgeprogrammeerde tegenspelers of middels bandopnamen (video of audio) aan proefpersonen wordt aangeboden (Van Son, 1978) . MCFal1 (1977) is van mening, dat deze 'simulaties" steeds een compromis met de werkelijkheid betekenen.

Een aantal auteurs heeft de relatie tussen gedrag in de natuurlijke ongeving en gedrag in simulaties expliciet onderzocht. Terwijl. Borgatta (1955), Kreitler en Kreitler (1968) en Stanton en Litwak (1955) significante correlaties van sterk variërende grootte rapporteren, melden Bellack, Hersen en Turmer (1978), Bellack, Hersen en Lamparski (1979), Miggun, Alonso en Pendleton (1979), McFall en Marston (1980) en Van Hasselt, Hersen en Bellack (1981) geringe of vooralsnog onduidelijke relatles.

Vexschillende auteurs wijzen op aan de onderzoeks-opzet gebonden factoren die een storende Invloed zouden hebben op de bevindingen, zoals het realiteitsgehalte van de simulatie (soms wordt de proefpersoon gevraagd wich "woor te stellen" dat hij zich in een nader beschreven situatie bevindt), het gehanteerde observatie-schema, de instructies, de context, de mate waxin er sprake is van "demand characteristics", de uitgebreldheid en dergelijke (Elsler, Hersen, Miller en Blanchard, 
1975; Galassi en Galassi, 1976; Nietzel en Bernstein, 1976, Fiedlex en Beach, 1978 en Higgins, Alonso en Pendleton, 1979 ).

\section{3 .2 Keuze voor simulaties}

Het 15 duldelijk dat het vaststellen van gedragskenmerken van hoogen laag-scoorders op Skims een gedegen onderzoeks-opzet vereist.

Bij beperkte middelen en tija is de voorkeur ultgegaan naax relatief uitgebreid onderzoek naar de validiteit van enkele skins boven sumier onderzoek over alle skims in de batterij.

Gekozen is voor simulaties in het laboratoriun ondat (a) deze minder tijdsintensief zijn dan observaties in de natuuxlijke ongeving, (b) omdat daarin de interpersoonlijke situaties voor alle proefpersonen constant gehouden kumen worden en (c) omdat de verrichtingen van de proefpersonen gemakkelijker op video kunmen worden vastgelegd, hetgeen ten goede kan komen aan de kwaliteit van de gedragsbeoardelingen lop een later tijdstip, met mogelijkheid van herhalde observatie). Deze voordelen gelden in versterkte mate voor video-simulaties waarbij de interpersoonlijke situaties tevoren op video zijn vastgelega en aldus gestandaardiseerd aan proefpersonen worden alangeboden. ook de genoemde twijfels aan de criterium-validiteit zijn echter in sterker mate van toepassing op video-sinulaties dan op live-simulaties. Besloten is daaron 1 in eerste instantie zowel video- als live-simulaties te ontwikkelen. Als beide typen simulaties overeenkomstige gedragingen lgedragsverschillen) oplevexen, kan in tweede instantie genoegen worden genomen met video-simulaties.

\section{3 .3 Keuze van criteria}

criteria bij uitstek voor de valialteit van de Skims zijn verschililen in overt interpersoonlijk gedrag tussen hoog-en laag-scoorders in de simulaties. Deze gedragskenmerken dienen door onafhankelijke obsexvatoren te worden vastgesteld aan de hand wan een observatie-schema dat kwantitatleve, kwalltatieve, globale en specifieke vragen en ultspraken over het betreffende gedrag onvat. 
Daarnaast $z$ ijn angstmetingen van belang. Rngst is inners nauw gerelateerd aan erwaren interpersoonlijke onvaaraigheid (zie 2).

Lick en Katkin (1976) anschrijuen angst als een respons-complex van verbale ultingen van vrees, verhoogde activiteit in het sympathische deel van het autonome zenuwstelsel, vermijdingsgedrag en gereduceerde gedragsefficlëntie. In deze brede definitle maken overte gredragskenmerken deel wit van het respons-complex 'angst'. In eerder bedoelde, engere zin spreekt 0.a. Spielberger (1972) van "state"-anxiety als een volbare en voorbijgaande enotionele toestand of conditie die gekaraktertseerd wordt door gevoelens van gespannenheid en vrees en verhoogde activitelit: van het autonome zenuwstelse1. Deze "state"-angst onderscheidt hij van 'trait'-angst, die hij beschouwt als een relatief stabiel. perswongkemerk, een preaispositile on met een verhoogd niveau van state-angst te responderen in stressvolle situaties.

In de meeste definities van angst speelt ook de fyslologische component een rol. Bij herhaling is echter aangetoond, dat ex weinig samenhang bestaat tusser gelijktijaig gemeten niveau's van fyslologische, motorische en verbale uitingen van angst (Lang, 1971).

\subsubsection{Angst en hartslagfrequentie}

Theunissen (1980) heeft een literatuurstudie uitgevoerd naar de psychofysiologische aspecten van emoties, toegespitst op de relatie tussen angst en hertslagfrequentie. Hij constateert daarin dat de hartslagfrequentie naast zweetsecretie en de galvanjsche huidrespons vaak gehanteerd wordt als index van verhoogde fysiologische activiteit. Karakteristiek voor de hartslag zijn in deze labilitelt en excessieve toename ten gevolge van 'minimale stimulatie' zoals voedselinname, lichamelifke insparningen en emotles. Theunissen stellt dat er aanwijzingen zidn dat

- toename van de hartslagfrequentie de enige fysiologische variabele is die significant corxeleert met zelfrapportages van angst,

- toename van de hartslagfregruentie ook gevolens van angst kan oproepen,

- zowel njeuwe, als vreend ervaren stimuli als conceptuele taken als schade-toebrengende stimuli de hartslagfrequentie kunnen doen toenemen, 
- deze toename echter ook afharkelijk is van de definitie van de situatie door het individu,

- de hartslagfrequentie daalt als de aandacht op de ongeving gexicht is zonder dat het individu zich daarbij betrokken voelt,

- bij dreiging met een electrische schok de toename van de hartslagExequentie groter is bij individuen die tevoren te kennen gaven bang te zijn voor een dergelijke schok,

- hoge-trait-angstigen bij bepaalde stimuli (anagram-taken b.v.) een grotere toename van de harts lagfrequentie vertonen dan laag-traitangstigen, doch dat dit bij andere stimuli (0.a. dreiging met schok) niet gelat,

- onder condities als dreiging met falen of afwijzing hoge-traitangstigen wel. reageren met hogere zelfrapportages van angst, doch niet met hogere hartslagfrequentie,

- hoge-trait-angstigen onder rustcondities een hogere hartslagfrequentie vertonen dan laag-trait-angstigen.

Eisler (1976) stelt dat fyslologische arousal in interpersoonlijke situaties soms als angst dan weer als prettige opwinding wordt ervaren en dat hoogvaardig interpersoonlijk gedrag blj somigen gepaard gaat met verhoogde fysiologische activiteit, bif anderen julst met een laag niveau. Twentyman en Mcrall (1975) hebben bovendien in een simulatieexperiment geconstateerd dat vermijaingsgedrag in een interpersoonlijke situatie de hartslagfrequentie weer reduceert. De relatie tussen angst en hartslag is kennelijk buitengewoon complex en laat nauwe lijkss toe voorspellende ultspraken te doen over de samenhang tussen de diverse responssystemen, noch ovex de in de simulaties te verwachten toename van de hartslagfrequentie.

Dat maakt het verzamelen van angstindices in de geplande simulatie echter niet minder interessant. Besloten is tyjaens de simulatie de hartslag te registrexen, de subjectieve 'state'-angst te meten en de socialle angst-als-dispositje te bepalen. 


\subsection{Opzet eerste rallidteltsstudie}

Besloten is een groep hoog- en laag-scoorders op skim 1 (een praatje maken) in een drietal simulaties te brengen, een 'Iive-simulatie' en twee "video-simulaties", en hunverrichtingen op video-banden vast te leggen om observatie door onafhankelijke beoordelaars op een later tijastip mogelijk te maken. Tevens is gekozen voor arie angstmetingen: soclale (tralt-) angst, (subjectieve) state-angst en hartslagregistratie.

\section{4 .1 De slmilaties}

Voor de live-gimulaties is een "wachtkamer" ingericht (12 $\left.\mathrm{m}^{2}\right)$, afgezet met kamerschotten. Twee van de zes zitplaatsen worden bezet door een jonge man en een jonge vrouw (niet naast elkaar); de vrouw leest in een tijdschrift. Deze "stooges' (geinstrueerde rollenspelers/medewerkers van de onderzoekers) hebben de opdracht geen inltiatief te nemen tot een conversatie, doch welwillend en kort te reageren als zij worden aangesproken. De proefpersoon krijgt de opdracht naar de wachtkamer te gaan en 'een praatje te maken op een manlex waarop u dat anders ook zou doen'. Als de proefpersoon te kennen geeft nooit een praatje te maken ondler dit soort (wachtkamer-) omstandigheden, kxijgt hij van de proeflelder de reactle: 'Stel dat $u$ vandaag wèl zin hebt on een praatje te maken'. Een grotendeels achter de kamerschotten opgestelde bemande videocamera registreert de verrichtingen van de proefpersoon. De proeflelder beedndigt de simulatie na 3 minuten.

De video-simulaties zijn als volgt opgezet.

De proefpersion staat 2 t meter voor een videoscherm. In de eerste slmulatie ziet hij een echtpaar, druk doende vakantie-folders te raadplegen en vakantle-mogelijkheden te bespreken. Als de bel gaat, opent de man de deux; het blijkt de buarman te zijn die een startkabel voor zijn auto komt lenen. De man-des-huizes verdwijnt uit beeld, op zoek naax de startkabels, zljn echtgenote met de buurman in de huiskamer achtexlatend. Vanaf dat moment wordt de video-scène een aantal malen onderbroken doox een "grijs vlak". De proefpersoon heeft tevoren de 
instructie gekregen on tijdens het grijge vlak "te reageren zoals hilj zou reageren als hij de buuman was' "De vrouw in de scene laat het initiatief duidelijk aan de burman.

ook in de tweede video-situatie wordt gebruik gemaakt van even videom scène met tussentijdse grijze beelden. Ditmaal betreft het een scène in een cafe. De proefpersoon wordt gevraga "te reageren zoals hil zou reageren als hij de man was die nu binnenkomt". De binnenkomende klant vindt een plaatsje aan de bar, bestelt wat, kjjkt mari de klariten (mannen) die naast hem zitten, waarna het eerste grijze beeld verschijnt. zowel de buuman als de barbezoekers zijn veertigers.

voordat de proefpersonen de proefruimte betreden, wordt hen vertela dat. 'er in die ruimte een camera is, die alles opneemt; hij stakt wat verdekt opgesteld, on niet te veel te hinderen; let u daar maar niet $o p^{\prime}$.

\section{4 .2 Proefpersonen}

Skim 1 is (tezamen met een aantal andere vragenlijsten) afgenomen bij 72 veertigjarige Maastrichtse mannen. Eerder was onder mannelijke veertigers een gemiddelde score van 11.0 met een standaardaeviatie van 3.0 op deze skim vastgesteld (bijlage 3). Na 2 maanden zijn 20 maximumscoorders (score 14) en 20 'laag-scoorders' (score-gemidalde 8.0) uitgenodigd om deel te nemen an de validiteitsstudie. Fen wordt meegedeeld aat het onderzoek 'is gericht op de wijzen warop mensen met elkaar ongaan".

\section{4 .3 Angstmetingen}

Meting van de sociale-angst-als-'trait" vindt plats m.b.v. de soclale Angst Schaal van Willems, Tuender-de Haan en Defares (1973) "die betrouwbaar en valide wordt geacht. Wllems $0.3 .(1973)$ hebben blj een 6-tal proefgroepen interne (KR .20) consistenties tussen .75 en .91 aangetoond en in een experimentele situatie, waxin 32 hoog-en 32 mannelijke laag-scoorders kennis maakten met een hen onbekena malsje, gevonden dat hoog-sooial-angstigen zich angstigex voelen en door observatoren als angstiger worden gepercipleerd. 
Subjectleve "Etate'-angst wordt gemeten met behulp van een angstthermoneter (walk, 1956), waarvan de nulwaarde verwijst naar 'afwezigheid van enige angst of onrust" en 100 naar 'zeex hoge angst, paniek'. De proefpersonen geven damop direct na het "live'-wachtkamer-praatje en na de videotaak aan hoeveel angst deze situaties bij hen hebben opgeroeper.

De hartslagregistratie vindt plaats via aambrenging van drie electroden op het bovenlichaam van de proefpersoon, verbonden met en om de heup gerlemde kleine recorder, die op batterijen werkt en de bewegingsvrijheid niet belemert. Een cardiotachometer meet de afstand tussen de p-toppen (de electrische uitarukkingen van de boezemcontracties) van het electrocardlogram en drukt deze wit in termen van slagen per ninuut. Over elke gewenste periode kunnen gemiddelden, minima en maxima, e.d. worden berekend. On de relatileve verhoging van de hartslagfrequentie te kunnen berekenen, worden de proefpersonen na afloop van de simulaties in een kamer afgezonderd en vitgenodiga om in een relaxatlie-fauteuil plats te nemen onder de mededeling dat "het erop zit; het is de bedoeling dat $u$ zich nog een paar minuten zo goed mogelijk ontspant'. De gemiddelde hartslag gedurende de vijfde mimut van deze 'rustperiode' zal als referentiepunt dienen woor de vaststelling van de verhoging tijdens de simulaties.

\section{4 .4 Gedragsbeooxdelingen}

Twee slechts zijdelings over het doel van het onderzoek geinformeerde gedragswetenschappers observeren achteraf en onafhankelijk van elkaar de video-opnamen van de verrichtingen van de 35 proefpersonen en beoordelen deze verxichtingen aan de hand van observatielijsten. De aan de observatoren voorgelegde vragen zifn zeex ulteenlopend van aard en varderen van aantal gesproken woorden, duux van de pauzes, motoriek (friemelen handen, knfpperen ogen), keuze van zitplaats, keuze van gesprekspartner, gespreksonderwerp, tot 3 à 5-puntsschalen over levendigheid, activiteit, e.d. voorbeelden van observatie-items treft men an in tabel 6.4. Een groot aantal van deze komt zowel in de wachtkamer-, als in de huiskamex- en café-observatilelijst voor. Over het gedrag tijdens de video-simulaties worden pèr grijs-beeld-periode the 
weten 10 tijjens de huiskamerscène, 6 tijäens de cafescènel een aantal standaardvragen aan de observatoren voorgelegd.

\subsubsection{Data-verwerking}

De gedragsobservaties worden per item onderworpen aan een toets op de interbeoordelaarsbetrouwbaarheid. Bij een significante ( $\mathrm{p} \leqslant .01)$ Kendail's tau van " 50 of hoger zal de overeensteming tussen de beide beoordelaars voldoende worden geacht.

De scores op de items die voldoende betrouwbar zijn, worden gestandaardiseera en vervolgens gesommeerd (onvoldoende betxouwbare items worden verder genegeerd), waarna met behulp van de Mann-Whitrey-U-test per litem wordt berekend of hoog- en laagscoorders op de Skim significant verschillen. Factor-analyse over de items waarbij dat het geval 1 s, kan steun bieden bij de interpretatie van het dan voorliggende materiaal. over de wachtkamer- en de videoperiode, alsook over de vijfde minuut wan de rustperiode worden de gemiddelde hartslag-frequenties berekend. omdat de hartslag-frequentie zich, evenals andere fysiologische variabelen, steeds beweegt tussen een per individu verschillende range is het nodig de nuwe werhoging te corrigeren voor deze range (Lykken, Rose, Luther en Maley, 1966).

over de voor individuele spreiding (range) gecorrigeerde gegevens wordt vastgesteld of er verschil is tussen hoog-en laag-skimscoorders. Volgens de wet op de initiële waarden kan de verhoging van de hartslag-frequentie belnvloed worden door de uitgangs(rust) waarde: bij een hogere rustwaarde zal er een geringe stijging optreden. Mocht uit een negatieve correlatie tussen rust- en test-waarden blijken, dat deze wet van toepassing is, dan zal de veranderingsscore gecorrigeerd worden tot een 'autonomic lability score' volgens de formule van Lacey (Johnson en Lubin, 1972). Vastgesteld wordt of hoog- en laagscoorders op de vaardigheidsmeter signiflcant verschilien op de Sociale Angstschaal en de Angsthe rmometerscores.

Pearsoncorrelaties tussen S.A.-scores, Angstthermometer- en haxtslaggegevens worden bexekend, teneinde inzicht te geven in de samenhang tussen de angstindicatoren. 


\subsection{Resultaten}

Van de 40 aangezochte proefpersonen (zie 6.4.2) hebben ex 35 aan de ultnodiging gevolg gegeven: 19 lag-scoorders en 16 hoog-scoorders.

\section{5 .1 Gedragsbeoorde lingen}

over de wachtkamer-verrichtingen vam de 35 proefpersonen hebben 2 observatoren 5.3 ultspraken gedaan. De interbeoordelaarsbetrouwbaarheld blijkt aan de gestelde norm (Kendall"s tau $\geqslant .50, p \leqslant .01$ ) te voldoen blj 26 van de 53 items. Twee "obserwaties" zijn slechts door én observator uitgevoerd: een telling van het aantal spreekbeurten en een telling van het aantal geproduceerde woorden. Zowel de 2 laatstgenoemde items als 19 van de 26 betrouwbare 1 tems, warvan de scores per observator gestandaardiseerd en vervolgens gesommeexd zijn, blijken te discriminexen tussen de groep hoog- en laag-scoorders (tabel 6.4). De resultaten wijzen uit, dat hoog-scoorders in vergelijking tot laagscoorders in de wachtkamersituatie als meer spontaan, zelfverzekerd, levendlg, losjes, open, initie̋rend en actief gezien worden. Verder zijn hoogscoordexs volgens de observatoren minder bang, weten ze zich een betere houding te geven en voelen ze zich meer op hun gemak. Ze maken betex contact, maken een vlotter pratje, zijn meer op de anderen gericht en letten ook meer op de reacties van anderen. Hun opmerkingen ziln behalve levendiger ook talrijker en uitgebreider. zij laten minder pauzes en stiltes valien, terwjl deze bovendien korter zijn. Tellingen bevestigen dat ar door de hoog-scoorders meer opmerkingen en meex woorden worden geproduceerd. Factor-analyse over de 21 discriminexende items wijst uit dat fén factor 71.4 van de totale variantle verklaart (de tweede factor nog slechts 8.0\%). De factorladingen van de 21 items varieren van .65 tot .94. Varimax-rotatie over 2 factoren leidt tot een factor 'kwantiteit" en een factor 'kwalitelt' met betrekking tot de vaardigheid in het maken van een praatje. 


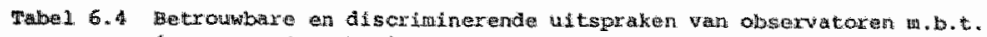

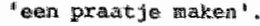

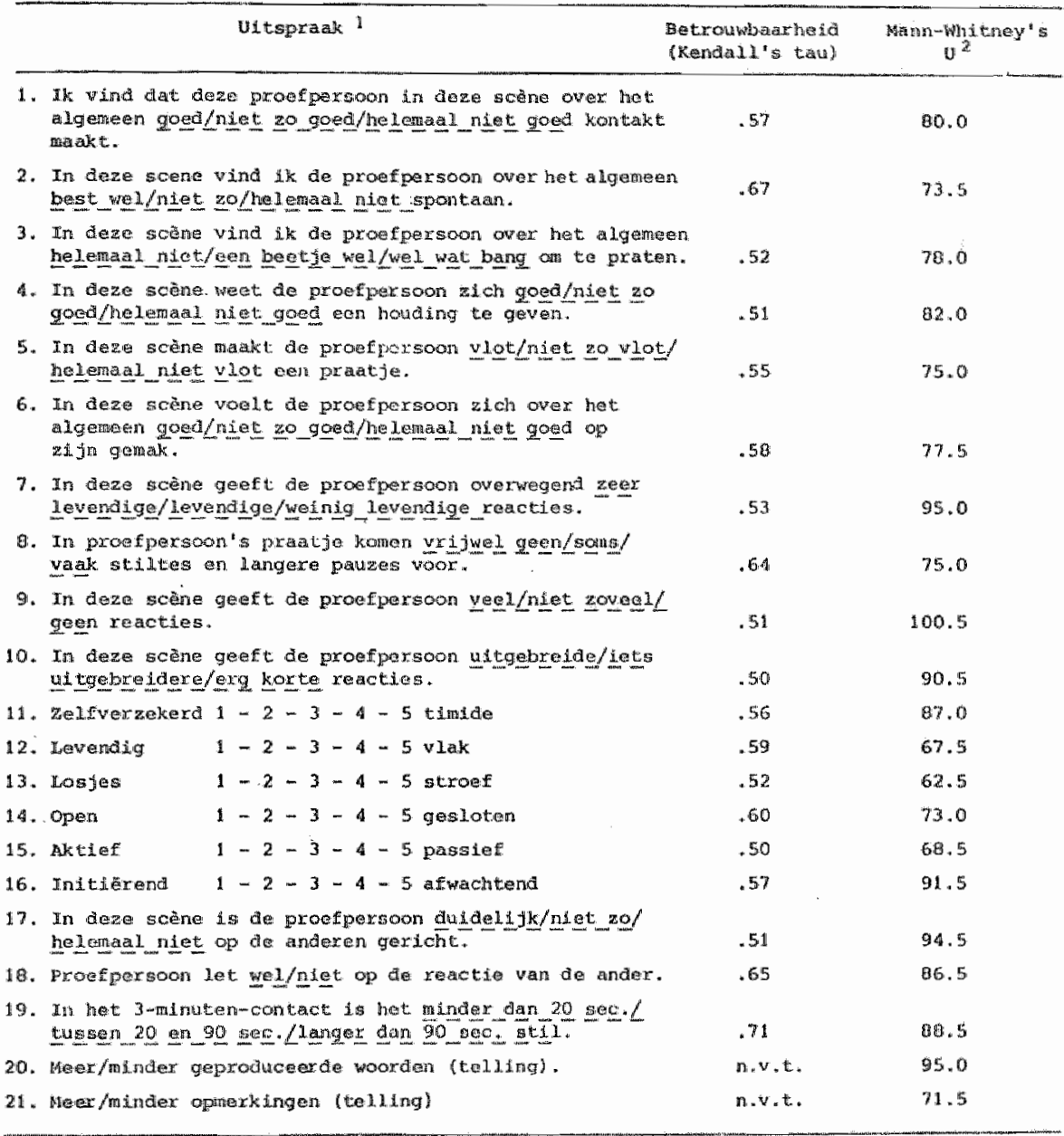

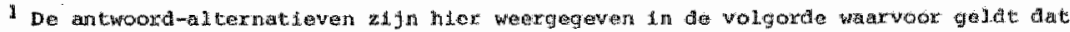

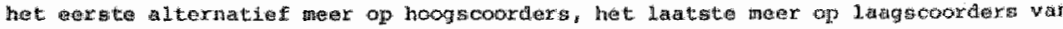
toreassing is

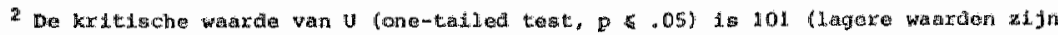
Elgiticint): 
Over de verrichtingen tifjens de video-huiskamer-situatie zijn door de obsexvatoren 117 ultgpraken gedaan. Dit grote aantal worat verklaard. doox het 10-tal grijze vlakken en de serie standaardvragen daarbij. Van deze 117 voldoen er 80 aan de gestelde norm voor de interbecordeLaarsbetrouwbarheid. Slechts 4 uitspraken blijken te discrimineren tussen hoog-en laagscoorders. Voor de video-café-situatie zijn deze amtallen achtereenvolgens 71,52 en 1 . De 5 discriminerende items blijken bovendien deel uit te maken van de serie standaard-vragen per grijs vlak. In 2 van de 5 gevallen betreft het bijvoorbeeld een telling van het aantal woorden. zo'n telling, 16-maal verricht, blijkt ook 16-maal betrouwbaar, doch slechts 2-mal discriminerend. Om die reden zijn nawwelijks betekenisvolle conclusies te verbinden aan de gedragsobservaties van de proefpersonen tijdens de video-simulaties.

\section{5 .2 Sociale angst}

De 16 hoog- en 19 laag-scoorders op de Skim is de Sociale Angstschaal van W11ems $c . s$. afgenamen teneinde hun sociale-angst-als-dispositie ('tralt') te bepalen.

Het verschll tussen de hoog-en laag-scoorders op de Skim is zeer groot en statistisch significant (zie tabel 6.5). De Skim is duidelijk geassocieerd met sociale angst als dispositie.

Trabel 6.5 sn-scores van hoog-en lagg-Skim-sicoorders.

\begin{tabular}{|c|c|c|c|c|}
\hline & $\mathbb{N}$ & Genil oidieldo & Stand. dev. & $\mathrm{v}$ \\
\hline hoog boordex & 16 & 28.2 & 12.0 & \multirow[t]{2}{*}{$11.0<0<.000$} \\
\hline latagcoordars & 19 & 58.2 & 12.9 & \\
\hline
\end{tabular}

\subsubsection{Angst the rmometex}

De proefpersonen hebben 2-maal een angstthermometer ingevuld "waarbij de 'hoeveelheid angst' $(0-100)$ is aangegeven (1) 'tijdens het praatje in de wachtkamer' en (2) "terwijl u bezig was met de video'. Uit tabel 6.6 blijkt, dat hoog-scoorders op de skim minder angst rapporteerden dan laag-scoorders; dit verschil is significant op .05 niveau 
voor wat betreft de live-situatie, maar niet voor wat betreft de video-situatie.

De video-situaties blijken hogere angsthermometerscores op te leveren dan de live-wachtkamersituatie (Wilcoxon matched-pairs signed-ranks test, $p \leqslant .0011$.

Tabe1.6.6 Angst therrometax scores var hoog- en laag-\$kimmscoorders.

\begin{tabular}{|c|c|c|c|c|c|c|c|}
\hline & \multirow[b]{2}{*}{$\mathbb{N}$} & \multicolumn{3}{|c|}{ 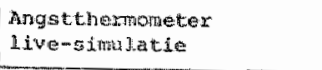 } & \multicolumn{3}{|c|}{ 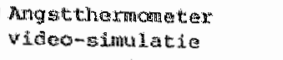 } \\
\hline & & Genida. & St. Diew. & 4 & Genidd. & St. Dev. & 0 \\
\hline hoogscootdiers & 16 & 18.1 & 18.0 & $\begin{array}{l}93.5 \\
(p<.05)\end{array}$ & 31.9 & 19.2 & $\begin{array}{l}120.5 \\
40.5 .4\end{array}$ \\
\hline Laeg scoorders & 19 & 33.2 & 25.2 & & 43.2 & 26.5 & \\
\hline
\end{tabular}

\section{5 .4 Hartslag}

De hartslaggegevens van 17 van de 19 lag-scoorders en van 14 van de 16 hoog-scoorders zijn technisch bruikbaar gebleken (zie tabel 6.7). van de wachtkamer-, de video (hulskamer en cafe-) en de vijfde minuut wan de rustperiode zijn de gemiddelde hartfrequenties bepadd en gecorrigeerd voor de individuele range volgens de formule:

gecoxrigeerde score $=100 \times \frac{\text { gemiddelde score }- \text { minimum score }}{\text { maximum score - minimum score }}$

(Lykken c.s., 1966). Alleen in de rustsituatie vertonen laag-5kimscoorders een relatief grotere verhoogde hartslagfrequentie dan hoogSkim-scoorders. Het verschil tussen de gemiddelde hartfrequenties tijdens de wachtkamexperiode en de vijfde minuut van de rustpexlode is bij hoogscoorders groter dan bly laagscoorders. Dit verschil is echter niet significant. Hetzelfae geldt yoor het verschil tussen de $v$ ideoperiode en de rust. 


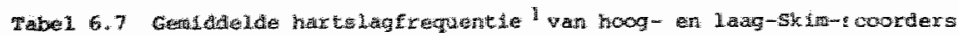

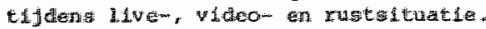

\begin{tabular}{|c|c|c|c|c|}
\hline & & 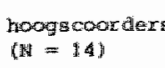 & & $\begin{array}{l}\text { Laasscoorders } \\
(\text { w } 17)\end{array}$ \\
\hline 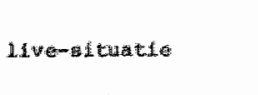 & $\begin{array}{l}\text { Gentad. } \\
\text { st.dew: } \\
\text { vergethd (u) }\end{array}$ & $\begin{array}{ll}49.4 & (98.7) \\
1.9 .3 & (19.1)\end{array}$ & $103.0($ n.w.) & $\begin{array}{l}43.91 \\
25.1(92.0) \\
(1.4 .8)\end{array}$ \\
\hline 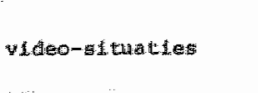 & $\begin{array}{l}\text { Gentida. } \\
\text { st.dav. } \\
\text { Vergcht (U) }\end{array}$ & $\begin{array}{ll}63.5 & (102.8) \\
19.7 & (22.2)\end{array}$ & $110.5(n .5)$ & $\begin{array}{l}61.2(98.4) \\
16.9(1.3 .6)\end{array}$ \\
\hline rute-gutede & 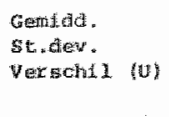 & $\begin{array}{r}4.9 \text { (83.9.) } \\
16 \ldots 0(14.4)\end{array}$ & $\begin{array}{l}\text { 61.5 (p .07 } \\
\text { owo-talledil }\end{array}$ & $\begin{array}{l}13.5(8,3) \\
24.9(8.9)\end{array}$ \\
\hline Werechid 1 He-ruat & $\begin{array}{l}\text { Gendad. } \\
\text { St.dev. } \\
\text { vextehil }\end{array}$ & $\begin{array}{l}14.8 \\
10.7\end{array}$ & $88.5(\mathrm{~m} . \mathrm{s} \cdot)$ & $\begin{array}{r}9.9 \\
11.3\end{array}$ \\
\hline werachil viabo-xust & 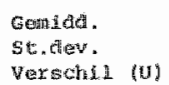 & $\begin{array}{l}10.9 \\
11.8\end{array}$ & $111.5(\mathrm{~m}, \mathrm{~s})$, & $\begin{array}{r}15.4 \\
8.7\end{array}$ \\
\hline
\end{tabular}

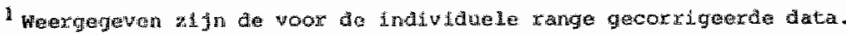
Tusian hakges de ruwe data.
}

Ex zijn geen correcties volgens de wet van de initiële wararden op de hartfrequentie-scores uitgevoexd. De aanlelding daartoe, nl. een negatleve correlatie tussen rustwaarden en wachtkamer- respektievelijk video-hartfrequentie blijkt niet aanwezig. Vergelljking van hartslaggegevens over de 3 registratie-perioden wijst uit dat de hartslagfrequentie in de videoperlode hoger is dan in de live-wachtkamerperiode, die op zijn beurt weer hoger is dan de frequentie in de vijfde minut var de rustperiode. Deze verschillen gelden zowel voor de ruwe als voor de op range gecoxrigeerde hartslagdata (Milcoxon matched-pairs signed-ranks test, $\mathrm{p}<.01$ ).

\section{5 .5 Rejaties tussen angst-inalcatoren}

Ex blijkt geen significante correlatie te bestaan tussen de angstthemoneterscores en de (on)gecorrigeerde hartslagdata. Ook de correlaties tussen de S.A.-scores en de hartslagfrequenties zijn niet significant. Wel significant zijn de correlaties tussen S.A. en de 2 angstthermometerscores: respektlevelijk .37 en .30 (Pearson, $p \leqslant .05$ ). 
Tussen de beide zelfrapportages van angst bestat derhalve een duldelijk verband.

\subsection{Een tweede validiteitsstudie}

Dok Skim 4A is aan een soortgelijk onderzoek onderworpen.

Gekazen is voor Skim 4 (reageren op kwaadheid) ondat het een van de 'reactieve' vaardigheden is en een van de vaardigheden waarin emoties een grotere rol spelen, en voor de A-versle (hoog-scoorders op de "agressieve" B-versie kunnen in een simulatie moeliljkheden veroorzaken).

Blj de proefgroep van mannelifke veertigers is op deze skim een gemiddelde score van 8.5 met een standaarddeviatie van 2.7 aangetroffen (zie bijlage 3). Twaalf "laag"-scoorders (scores tussen 3 en 6) en zeven maximum-scoorders (score 12) zijn in een live-wachtkamer-simulatie gebracht, ditmaal met een 'instructie" die geen aawijzing inhoudt ten aanaien van het te observeren gedrag: "Het is de bedoeling dat $u$ in die wachtkamer hier even wacht; er zitten nog een paar mensen ... maakt u maar een praatje met ze'. Als de proefpersoon de deur van de wachtkamer opent om naax binnen te gaan, stoot hij met de deur tegen de rug van de hand van een jongeman, die darap zijn plastic bekertje met koffie laat vallen. Deze stooge, een student van de Toneelacademle Maastricht, is erin geslaagd een groot aantal kexen op nagenoeg ldentieke wijze kwaad te worden: in woord en daad blijk te geven van verontwaardiging, de proefpersoon te beschuldigen wan lompheid, etc. Deze simulatie duurt 3 minuten. Na afloop is de proefpersoon meegedeld, dat e.e.a. in scène gezet was, doch dat dat omwlle van het 'verrasalngseffect' is verzwegen. Geen der proefpersonen heeft te kennen gegeven dat hil "het door had'. 


\subsubsection{Gedragsbeoordelingen}

Twee observatoren hebben de op video vastgelegde verrichtingen van de 19 proefpersonen onafhankelijk van elkaax beoordeeld aan de hand van een observatie-schema. Van de 37 items voldoen ex 18 aan de gestelde els woor de interbeoordelararbetrouwbarheid (Kendall"s tau $\geqslant .50$, p .01). Wa standaardisering en somexing van deze 18 item-scores blijken 7 tems te discrimineren tussen hoog-en laag-scoorders op Skim 4 A (zie tabel 6.8).

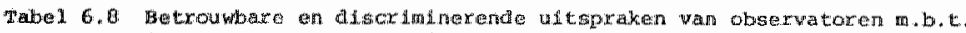
'reageren op kwadmata'.

\begin{tabular}{|c|c|c|}
\hline Ud topratik & 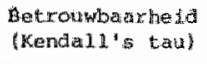 & $\begin{array}{l}\text { Discriminerend } \\
\text { (Hann-unitney o }\end{array}$ \\
\hline 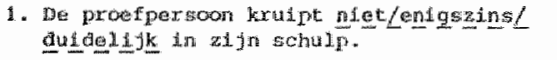 & .50 & 10.5 \\
\hline 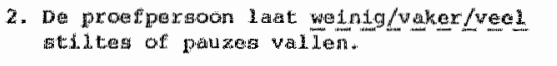 & .59 & 16.5 \\
\hline 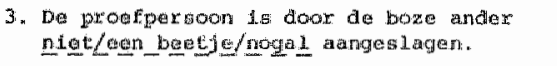 & .50 & 18.0 \\
\hline 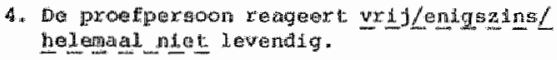 & .50 & 18.5 \\
\hline 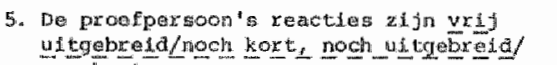 & & \\
\hline erg kort. & .62 & 19.0 \\
\hline H. Usidend $1-2-3-4-5$ volgend & .55 & 21.0 \\
\hline 7. Sterk $1-2-3-4-5$ zwalk & .50 & 17.5 \\
\hline
\end{tabular}

1

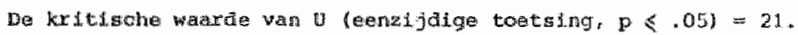

Irag-scoorders krulpen volgens de observatoren meer in hun schulp. zily meer aangeslagen doox de boze ander, geven kortere en minder levendige reactles en laten meer stiltes of pauzes vallen. Dit in tegenste Illing tot hoog-scoorders die bovendien worden gezien als sterker en meer leidingnemend. Factor-analyse over de 7 discriminerence 1 tems levert én factor op die 16.4 van de variantie verklaart, met factorladingen tussen .85 en .93 . 


\subsection{Angstmetingen}

ook hier blijken hoog- en laag-skim-scoorders vrij fors en statistisch significant te verschillen m.b.t. scores op de Sociale Angstschaal. vit tabel 6.9 is eveneens af te lezen, dat er geen significant verschil is geconstateerd op de angstthexmometex en de hartslagverhogingen. De Pearsoncorrelatie tussen S.A.- en angsthermometerscores is .35 $(p=.05)_{;}$de correlaties tussen diverse hartslag-scores en de zelfgerapporteerde angstmaten zijn niet significant.

Tabel 6.9 Angstretingen bif hoog- en laag-shim-scooraers m. b.t. "reageren op kwandheid".

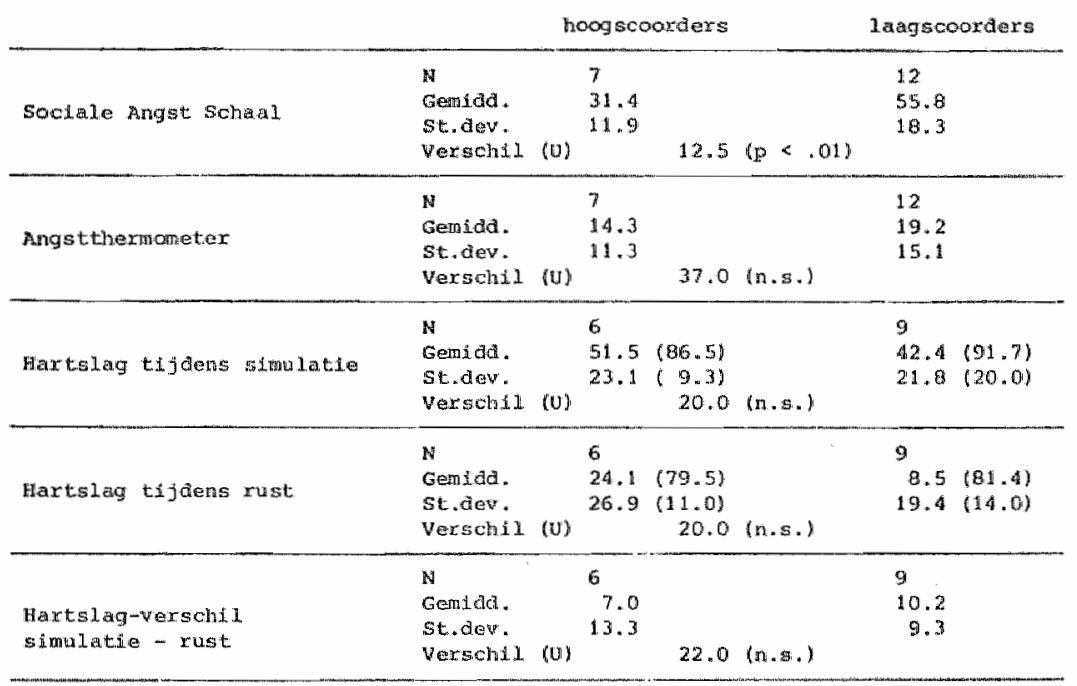

\subsection{Discussie en conclusies}

De constructie van een batterij interpersoonlijke vaardigheldsmeters, afgestemd op een 'programm-aambod" van 9 interpersoonlijke vaardigheidstherapieên, is gestart met het verzamelen van klachten in de vorm van onvaardigheidsuitspraken onder naar deze progranma's verwezen 
olienten. Dieze werkwijze is gevolga an de te ontwikkelen instrumenten qua moetlijkheidsgraad en taalgebrulk zo goed mogelijk af te stemin op de doelgroep: clienten ult lager sociaal-economische klassen. De verzamelde onvardigheidsuitspraken zijn bewerkt tot dxie-keuze-items. De aldug ontstane 9 "voorlopige Skims" zijn na invulling door groepen Maastrichtse veertigjarige mannen aan factor-analyses onderworpen.

\section{7 .1 Tyen onvaardigheid an de Skims-battexij}

In elke aralyse $1 s$ een factor gevonden met hoge ladingen van items die de mate uitdrukken warin men zich tot uitvoering van de betreffende interpersoonlijke activiteit in staat acht, daar bang voor is of deze vermijdt. In 4 gevallen is een tweede factor aangetroffen die betrekking heeft op de mate warin men zich gehinderd acht door ongeduld, kwaadheid, irrltatie. De hoogladende items op de 13 factoren hebben betrekking op meerdere 'modaliteiten': kunnen, durven, weten hoe, doen, enz. Op grond van 1tem-ladingen (hoog, homogeen) zijn 9 'A-Skims' en 4 "B-Skims" vastgesteld. Het is waarschijniljk dat het B-type-onvaardigheld ook voorkomt bij de 5 owerige interpersoonlijke vaardigheden. Kennelijk zijn. in de periode watarin blj cliënten 'ziek-uitspraken' zijn verzameld de onvaardigentype-B minder vertegenwoordigd geweest in c.q. minder verwezen naar deze 5 ondervraagde subgroepen. Hervatting van klachten-verzameling ter voltooling van subbatter $\mathbf{j}-\mathbb{B}$ liykt dan ook gewenst.

De afname van de Skims, voor een deel tweemaal, bij groepen veertigJarlge Maatrichtse mannen, heeft bevredigende betrouwbararhelds- en stabiliteitscoefficlénten opgeleverd. De interne samenhang van de items in de 13 skims mag als voldoende worden beschouwd en de test-hertestcorrelatles met een interval van een half jaar tonen dat de skim-scores niet een 'vorm van de dag', doch een duurzaam persoonskenmerk betreffen. 


\section{7 .2 De criteriumvalidutelt van 'video-simulaties'}

In de eerste waliditeits-stuaie is gebruik gemakt van zowel 'Ilve-' als "video-simulaties'. Daarbij bleken de video-simulaties gepaard te gaan met een hogere hartslagfrequentie en hogere angst thermometerscores dan de live-simulatie. Deze verschillen zijn kennelijk vexoorzaakt door een of meer van de volgende kenmerken, eigen aan de video-simulaties:

- het ongewone, onnatuurlijke karakter van praten-tegen-een-videobeeld,

- het ontbreken van invloed op het gedrag van de antagonist c.q. op het verloop van de scène,

- het dwingende karakter van het op-grijs-springende beeld, dat dicteert op welk moment en voor hoelang de proefpersoon moet/kan reageren,

- de instructie aan de proefpersoon zich voor te stellen, dat hij zich in de getoonde situatie bevindt en wel "in de huid' van een aangewezen andex.

Deze kenmerken gelden niet voor de live-simulatie, noch voor interpersoonlijke situaties in de natuurlijke ongeving.

De verhoogde stress (hartslag, angst) tijdens de video-simulaties rechtvaardigt te concluderen dat de criterium-validitelt van de video-simulaties geringer is dan die van de live-simulaties.

\section{7 .3 De validiteit van de_Skims}

De live-simulatie, een praatje maken in een wachtkamer, leldt tot de bevinding dat hoog-skim-scoorders in vergelijking tot laag-scoorders: - volgens obsexvatoren vaardiger zijn in het maken van een pratje, hetgeen tot uitarukking komt in een serle onderiling sterk samenhangende oordelen van kwalltatieve on kwantitatieve aard,

- minder angst rapporteren.

Deze verschillen treden niet op in de video-simulaties.

De tweede validiteitsstudie, een live-simulatie "reageien op kwaadheid" leidt met betrekking tot de gedragsobservaties tot gelljksoortige 
bevindingen: Laag-skim-scoorders $z i j n$ waameembaar minder bedreven dan hoog-scoorders in het reageren op kwaadheid.

De angsthemometer significant.

In beide validiteitsstudies is er geen verschil geconstateerd tussen hoog-en laag-skim-scoorders voox wat betreft de (relatieve) toename van de hartslagfrequentie tijdens de simulaties. Sociale Angst-scores bleken niet te correleren met hartslag-toename. Het is denkbaar dat. de door de proefpersonen gehanteerde definitie van de situatie en coping-stijl de hartslag hebben beinvloed: terwijl de bij hoogscoorders vastgestelde activiteit, levendigheid en initiatiefname de haxtslag hebben kunnen daen toenenen, zou aan de passiviteit van de laag-scoorders de angstreducerende werking van vermijdingsgedrag toegeschreven kunnen worden.

De $2(\mathbb{A}-)$ Skins zijn duidel.j.jk geassocieerd met de S.A.-schaal: laagSkim-gcoorders blijken sociaal-angstiger te zijn dan hoog-Skimscoorders.

voor 2 skims gelat dat de essentiële validiteitsvraag is beantwoord: hoog-scoorders vertonen waarneenbaar vaardiger gearag dan laagscoorders. Hoewel daamee geenszins de validiteit van de overige 11 Sklims is aangetoond, mag, gezien de identieke wijze van constructie, verwacht worden dat ook de overige skims bij nader onderzoek valide zullen blijkeri te zijn. 
7. EFFECTEN VAN INTERPERSOONLIJKE VAARDIGHE IDSTHERAPIEEN VOOR KANSARMEN

Dit hoofdstuk gat over de effecten van de eerderbeschreven interpersoonlijke vaardigheidstherapieen. De keuze van criteria en meetinstrumenten wordt toegelicht, waarna de proefgroep en de meettijastippen worden behandeld. Per criterium worden vervolgens de resultaten weergegeven, terwijl ook effecten van meerdere deelnamen en effecten na een jaar aan de orde komen.

Zoals in de hoofdstukken 4 en 5 reeds tot ultarukking kwam, zijn de ontwikkelde interpersoonlijke vaardigheidstherapieën voor kansarmen reeds in bedrijt gesteld. Terwljl aanvankelijk een kleine groep van vier projektgroepleden/therapeuten in 2 zulalimburgse RIAGG's de methode al werkende tot ontwikkeling bracht, zijn ex in latere fasen een honderdtal medewerkers van 15 instellingen in Limburg opgeleid on de methode toe te passen. In de 5 Limburgse RIAGG's tesamen zijn in het afgelopen jaar ongeveer 250 clieznten naar vaardigheidstherapleën verwezen, doorgaans voor deelname aan 2 à 3 theraple-progxamma's. De 25 aldaax werkzame vaardigheidstherapeuten hebben in dat jaar ongeveer 70 groepen uitgevoerd om deze verwijzingen te verwerken . Vet aantal vaardigheidstherapeuten, vexwijzingen en groepen neemt nog steeds toe. De ontwikkelde vaardigheidstherapieen voorzien kennelijk in een grote behoefte. Met recht kan men echter de vraag stellen: werkt deze methode ook? Daarbij is niet zozeex de vraag interessant of deze methode, toegepast op een wel omschreven clienten-subcategorle, ultgevoerd door bepaalde thexapeuten onder bepaalde condities vruchten afwerpt. 
Beleldsbepalexs, geldverschaffers, ultwoerders en clienten zijn op dit inoment weirig gebat met (aanviliende) inzichten in de effectiviteit van de varardigheidatherapleën onder laboratorium-condities. Van groter belang is het zichtbaar te maken of de "vertaling" van verzamelde inzichten in een geintegreerd geheel van therapeutische hulpmiddelen, handleidingen en opleidingsprogramma"s woor therapeuten, instructies en verwijzers, e.d. ulteindelijk heeft geleid tot een praktijkvoering die dan zijn doelstellingen beantwoordt.

\subsection{Criteria en meetinstrumenten}

De deelname aan een of meer interpersoonlijke vaardigheidstherapieer. doox een cliënt vormt steeds een ondexdeel van een meex onvattende behandeling. Een 'hoofdbehandelaar' wordt geacht een cliënt naar vaardigheidstherapleen te verwljzen nadat in goed overleg met de client is vastgesteld dat deze gebaat zal zijn net die deelname c.q. met het vergroten van bepaalde, nader gespecificeerde, interpersoonlijke vaardigheden.

\subsubsection{Vergroten van interpersoonlijke vaardigheden}

Als eerste en centrale vraag geldt dan ook: leiden de interpersoonlijke vaardigheidstherapieen tot grotere vaardigheden bij de deelnemexs? ondat elke varaxdigheidstheraple éen specifieke interpersoonlifke vaardigheld als doelvaardigheid heert, kan deze vraag vernegenvoudiga worden: leidt deelrame aan een interpersoonlijke vaardigheidstherapie mot als doelvaaraigheld "Opkomen voor je mening" tot een grotere vaaxdigheld in het "opkomen voor je mening', etc. In hoofdstuk 6 is de ontwikkeling en validering van een serie interpersoonlifke vaardigheidsmeters (skims) beschreven, die het mogelijk maken op efficlënte wijze vaardigheidsmetingen uit te voeren. Daarbij is tevens gebleken dat er sprake ls van twee onafhankelijke typen onvaardigheid: een onderdanig type vaardigheid-'A' en een ongedurig type 'B". Er zijn op dit moment 9 A-meters en 4 B-meters beschikbaar; 
in de periode dat de data-verzameling voor het hiex beschreven uitkomstenonderzoek plaatsvond, waren ex echter slechts 7 A-Skims an 4 B-Skims beschikbaar. De.2 ontbrekende A-Skims hadden betrekking op de vaardigheden "Uiten wan-' en 'Reageren op genegenheid en waardering". Verwacht wordt dat deelname aan een interpersoonlijke vaardigheidstheraple leidt tot vergroting van de doelvaardigheid c.q. tot hogere scores op de betreffende $\operatorname{skim}(\mathrm{s})$.

\subsubsection{Reductie van 'specifieke klachten'}

De toepassing van kant en klare instrumenten ter bepaling van de effectiviteit van een therapie-programma kan zowel tot over-als tot onderschatting van uitkonsten leiden.

Er wordt daarbij immers geen rekening gehouden met de specifieke doelstellingen van de individuele cliënten. Die overweging heeft er toe geleid dat men in therapie-effect-onderzoek in toenemende mate gebruik gemakt heeft van "individu-specifieke" instrumenten (Battle, Imber. Hoehn-Saric, Stone, Nash en Frank, 1966; Waskov en Parloff, 1975 ; Kieslex, 1977; Schagen, 1979).

ook voor deelnemers aan interpersoonlijke vaardigheidstherapieen geldt dat elke cliënt bij elke deelname specifleke verwachtingen koestert. Gekozen is voor een meetprocedure, afgelleld van de 'target-symptoms"meting van sloare, Staples, Cristol, Yorkston en Whipple (1975). Daarbit worat de cliênt in een individueel gesprek vooraf aan zijn deelname gevraagd: "U' gaat deelnemen aan een groep om te leren .... (naam van de vaardigheid). Wat is uw probleen met ....; wat vindt u daar moeilijk aan?'. Uit het antwoord van de clibnt worden door de interviewer maximaal 3 "symptomen" gelicht en zoveel mogelijk in elient's verwooraing daarvan qexegistreerd. Terwijl hij de client doorvraagt over deze 'specifleke symptomen', maakt de interviewer een schatting van de ernst van elk van deze symptomen en scoort die als mild (3), vrij ernstig (4) of ernstig (5). Symptomen die aanvankelijk genoemd worden doch in tweede instantie door de client als triviaal of niet (meer) anwezilg wotan beschreven, zijn verder genegeerd. 
Na afloop van zijn deelname an de betreffende vaardigheidstherapie wordt de client herinnerd aan wat hij in het interview-vooraf aan "symptomen" heeft ingebracht en wordt hem per symptoon gevraagd "hoe. het daax nu mee statat". Behalve een "exrst-score" op een 5-puntsschal (1-afwezig, 2-in geringe mate aanwezig, 3-mila, 4-vrij ernstig, 5-exnstig) bepalit de interviewer in overleg met de client in welke mate de client de betreffende klacht als verbeterd of verslechterd ervaart. Scoxing geschiedt op een 13-punts-schaal, van -6 tot $* 6$, waarvan een vijftal punten nader zijn onschreven, als volgt:

+6 niets neer van over, compleet verbeterd

+3 er is werbetering te zien

0 ex is niets veranderd t.a.v. deze klacht.

-3 er is sprake van een achteruitgang/verslechtering

-6 in zeer sterke mate verslechterd.

De interviewers zijn eraan gehouden, voor de ultvoexing van het tweede interview geen kennis te nemen van de ernst-scores bepaald in het eerste interview.

Verwacht wordt dat de intexpersoonlijke vaardigheidstherapieën leiden tot een reductie van de individu- en programm-specifieke "doel-klach$\operatorname{ten}^{\prime \prime}$.

\section{1 .3 Vergroting van zelf-waardering}

In eexdere hoofdstukken is herhaaldelijk het concept 'self-efficacy' aan de orde geweest. Verwachtingen van eigen competentie hebben een zekere mate van speclficlteit c.q. zijn in bepalde mate gegeneraliseera. In en vaardigheidstherapie wordt getracht een specifieke interpersoonlijke competentie alsook de persoonlijke verwachting van de cliënt met betrekking tot die competentie te vergroten. Verondersteld wordt dat een vergroting van specifieke competenties ook bijaraagt tot groei in a-speclfieke zelfwardering, m.a.w. In gegeneraliseerd geloof in algemene competentie. 'As therapy proceeds", aldus strupp (1978), "the patient typically experiences an increase in self-esteem and selfwoxth, regardless of the extent or nature of behavior change". Deze algemene zelfwardering-versus-zelfdepreciatie heeft geen betrekking op het geloof in de efectiviteit wan gedrag en kan dan ook niet, 
zoals Riksen (1981) aanneent, gemeten worden met een schaal voor interne versus externe beheersing (I-E; Rotter, 1966, Andrjessen, 1972). Als meetinstrument poor algemene zelfwardering is hier gekozen voor een self-esteem (S.E.)-schaal, ontwikkeld door Rosenberg (1965), vertaald en bewerkt door Sanders (1977) en later door diverse onderzoekers in meerdere versies toegepast. De hier gebruikte verste wan 15 items met elk 6 antwoordwogelijkheden (zie bilylage b) heeft een minimumscoxe van 15 en een maximumscore $\operatorname{Wan} 90$, na afname onder 201 Libo-clianten blijkt deze versie een interne consistentie te hebben van . 83 .

\subsubsection{Reductie van algemene $\mathrm{klachten}$}

De aan de varardigheidstherapieën deelnemende cliënten melden zich in het algemeen uiteraard niet bij het RIAGG an een of enkele specifleke vaardigheden te verwerven. De 'hoofdklacht' zal doorgaans een andere zijn, een "breder" probleem, wellicht ook vager, maar voor due client meer relevant. Deelname aan een specifleke vardigheldstheraple, het aanlexen van de juiste vaardigheld op het juiste moment, kan een zinvolle bijdrage inhouden tot verwezenlijking van client's voornaanste drijfveer tot behandeling: reductle van $z i j n$ eigenlijke "target symptoms". Deze deellname, onder opschorting van de "hoofabehandeling ', kan in de praktijk echter ook uitpakken als een uitstel van verbetering van hoofdklachten. Als de vaardigheidstherapieẽn, zoalsi Van Son (1980) vreest, als panacee voor de meest uiteenlopende geestelijke gezondheidsproblemen worden gebruikt, kan een eventuele vaardigheidsuitbreiding wel eens ten koste gaan van het bereiken van de eigenlijke behandelingsdoelen.

Teneinde uitsluitsel te krijgen over de vraag of de vaardigheidstherapieen bijaragen tot verlichting van individu-specifieke algemene klachten woxden ook metingen op hoofdsymptomen c.q. algemene klachten ultgevoerd. De proceduxe is dezelfide als bij de specifleke klachteny de leldende vraag is ditmal: "Wat is de reden dat u bij deze instelling in behandeling bent? wat zijn uw voornaamste problemen of klachten?'. Uit het antwoord worden maximaal $3 \mathrm{klach}$ ten gelicht. Naast de bepaling van 'ernst-scores" "voor en na deelname aan de therapie, wordt tijdens de nameting vastqesteld in welke mate de client van mening is dat er, 
per symptoom, verbetering of versiechtering is opgetreden.

De 2 eerstgenonde criterla, vardigheldsvergroting en reductie van individuele varatgheids-specifleke klachten, kunnen 'goal-based' genoemd worden: de criterlia vloeien voort uit de doelsteling en de pretentle van de vaardigheidsthexapie. Wergroting van zelfwaraering en ceductie var individuele algemene klachten zijn daarentegen als 'goalfree' theschowwen: deze uitkomstcriteria zijn niet direct ontleend aan aard en doel van de interpersoonlijke vaaraigheidstherapleên, doch hebben betrekking op 'elsen" die men aan elke vorm van behandeling miag stellen.

\subsection{Proefpersonen en data-werzameling}

In een pexlode van 3 jaar zijn pre- en postmetingen verricht bij cliênten, verwezen naar interpersoonlijke vaardigheidstherapieën in 2 RIAGG's *

\section{2 .1 Experimentele groep}

De experimentele groep worat gevormd door clienten die deelnemen aan een of meerdere interpersoonlijke vaardigheidstherapieën.

Op deze cliënten is geen enkele vorm van (verdere) selectie toegepast. opname van een deelnemex in het databestand is afhankelijk geweest van a. beschikbaarheld van interviewers. In perioden waarin de projectgroep beschlkte over voldoende interview-capaciteit zijn er meex data verzamela.

b. de tijd tussen aamelding en eerste groepszitting. Cliënten, qie in de week voorafgaande aan de start van een vaardlgheidstheraple naar dit programma worden verwezen, konden over het algemeen niet meer tijalg berelkt worlen voor een interview.

c. het tot stand komen van een interview. Vergeten afspraken, afmeldingen, misverstanden over plaats of tijdstip van een ontmoeting zijn veelvuldig vooxgekomen. Openlijke welgeringen tot deelname aan een 
Interview waxen zeer sporadisch. Ook de aldus onberelkbare deelneriers ontbreken in het databestand.

d. daadwexkelijke deelname. Naar schattung 20 van de verwezen en an een groep toegewezen cliënten neemt in feite niet of in onvolaoende mate deel aan dat programa. Het bijwonen van minstens 3 van de 4 groepsbijeenkomsten is als norm gesteld voor opnane c. $\mathrm{c}$. handhaving van een deelnemer in het experimentele databestand.

Bij 202 cliënten zijn enige biografische gegevens verzameld. Van die cliënten is 59 van het mannelijke en 41 van het vrouwelijke geslacht. Slechts enkele cliënten zijn jonger dan 20 of ouder dan 50 jaax; twintigers en dertigers vormen elk $35 \%$ van het deelnemersbestand, de veertigers 22: "Terwijl 59\% gehuwd is of samenwoont, blijkt $28 \%$ ongehuwd, 9\% geschelden en 3 weduwe of weduwnaar. $56 \%$ van de clienten heeft geen werk buitenshuis; als redenen daarvoor worden genorma arbeiásongeschiktheid (378), ziek (258), werkeloos (128) en huisvrouw (258). Gevraagd naar de schoolloopbaan blijkt 26 slechts lager onderwijs te hebben gevolgd. 17\% heeft daar nog eén of twee jaar vervolgonderwijs bij gevolgd, 38\% voltooide een lagere beroepsopleiding (LTS, LENO, IEAO, etc.) of volgde 3 jaar vervolgonderwijs zonder een diploma te behalen, $15 \%$ voltooide MULO, MAVO, MBO, MTS o.i.d. of volgde 5 jaar HBS of HAVO zonder deze af te maken, 48 genoot mér onderwijs. Slechts 3 personen blijken particulier te zijn verzekerd (Inkomensindicatie), de rest via het zlekenfonds. Van degenen die een bexoep opgaven (618) noent 628 een uitvoerende 'blue collar'-functie in de bouw, de industrie, het transportwezen of bij een (semi-) overheidsinstelling, 17\% administratieve en technische kantoorfuncties, 14 betref wrouwen die hus w houdhulp, verkoopstex 0.1.a. opgeven, 5 is of was 'klelne zelfstandige' en 2 heeft een "hogere" functie.

\section{2 .2 Controle-groep}

De tija die verstrijkt tussen aamelding van een client en de start van zijn deelname aan een vaardigheldstherapie beslaat over het algemeen enige weken. In die wachtpexiode houdt de toekomstige deelnemer normaal contact met zijn individuele behandelaar/verwijzex. 
De aard van dit contact is niet verder onderzocht. Gedurende de 4 weken dat de vaadigheldstherapie loopt, worden deze ontmoetingen In de regel opgeschort of geminimaliseerd. Bij clienten, waarvan te yoorzlen was dat zij 6 weken of langex op de wachtlijst zowden moeten verblifven, zljn enige tientallen 'controle-metingen' verricht. Deze controle-wetingen maken het mogelijk vast te stellen of de goalbased ultkomsten (grotere doelvaardigheld, afname van specifleke klachten) inderdaad in grotere mate bereikt worden door deelname aan een vaardigheidstherapie dan zonder die deelname "spontaan" het geval zou zijn. Bowendien wornt de controle-conditie het 'natuuxlijke altermatief" voor de cliët: zonder de mogelijkheld van verwijzing naar interpersoonlijke vaardigheldstherapleën in de RIAGG"s zouden de 1 ndividuele behandelingen worden voortgezet.

Met betrekking tot de goal-free criteria (zelfwardering en algemene klachten) maken de controle-metingen het mogelijk te bezien of de praktlyk van verwijzing naar en uitvoering van interpersoonlijke vaardigheldstherapieen geschiedt op een wijze die in het belang is van de clienten, c.q. of ex een vexschil is tussen de experimentele en de controle-conditie in de mate warin deze uitkomsten bereikt worden.

\section{2 .3 Tijdstippen en wijze van data-verzameling}

Voor expeximentele pre-metingen zijn clienten ongeveer een week voordat het programma waaraan ze deelnemen van start ging ditgenodigd voor ean individueel gesprek. Voor controle-metingen was deze periode ongeveer 6 weken. Experimentele post-metingen zijn ongeveer een week na afloop wan het programma uitgevoerd. Controle-nametingen 5 weken na de woometing c.q. eien week voor de start van het programma. Als tijastip voor de nameting wordt dit eigenlijk te vroeg geacht. De vaardigheidstherapie is Immers van korte duur en vrij intensief en wordt afgesloten met huiswerkopdrachten voor meerdere weken. Een post-meting 4 weken ma beeindiging van het programma zou een beter beeld kunnen geven van de berelkte effecten. De data, verzameld op een later tijdstip, zouden achter weer een vertekend beeld kunnen geven van de resultaten, doordat zily mede-bepaala worden door de resultaten van de contacten van de cliènt met zijn hoofdbehandelaar, die in de regel 1 à 2 weken na afloop van de vaardigheidstherapie hervat worden. 
Regelmatig heeft in een ontuoeting met een client zowel de nameting van de ene vaardigheidstherapie als de voormeting van een andere plaatsgevonden. Dit gebeurt in die gevallen dat bekend is dat de client. binnen twee weken aan een volgende vaardigheidstheraple gaat deelnemen. aan wel als de client voor een controle-meting in aamerking komt omdat hij 6. weken moet wachten voordat hij kan deelnemen aar het volgende therapie-programma waarvoor hij is aangemeld. In dergelijke gevallen zijn de meetpakketten slechts voor een deel dubbel, ondat varielfsprekend de algemene (goal-free) instrumenten, SE-schaal en Algemene Klachten Lijst, slechts eermaal worden ingevuld.

Een individuele cliënt kan dan aok meerdere malen in het databestand vertegenwoordigd zijn, zowel als experimentele- en als controle-persoon. Indien het een expeximentele meting betreft is voor zover mogelijk steds geregistreexd op de hoeveelste deelname aan een vaardigheldsprograma deze meting betrekking heeft. Bij controie-nametingen, voor de cliëntan. een soort herhaling van de voormeting, is door de interviewer steeds de mededeling giedaan dat het voor het onderzoek nodig is dezelfde vragen nog eens te stellen.

onvolledige meetpakketten zijn meer regel dan uitzondering. De skims zijn pas ir een latere fase ontwikkeld en konden dus in eerdere fasen niet worden afgenomen. Het identificeren en waststelien van de ernst van individuele (specifieke en algemene) 'target-complaints' blifkt vaak een tijdrovende en soms zelfs onmogelijke opgave voor de lnterviewer. Soms zijn ontmoetingen om redenen van tija en organisatie afgebroken voordat alle scores verzameld waren.

De interviews zijn gehouden door verschillende projectgroepleden: de meesten door tijalijke krachten (HBO-niveau) en stagiairs (doctoraalstudenten psychologie). Als vaste regel is daarbij gehanteerd dat de interviewer geen therapeut van de betreffende client mag $z i j n$. De interviewer arrangeerde, na daartoe toesteming te hebben gevraagd van de betreffende (verwijzer-) hoofdbehandelaar, telefontsch of schriftelijk een ontmoeting met de verwezen cliët. 
SE-schalen en Skims zijn door de clienten zelf ingevuld, de beide kachtenijisten zijn door de interviewer ingevuld op basis van de uitlatingen van clienten. De duw van deze ontinotingen varieert van 2 tot 5 kwartier.

\section{2 .4 Herhalde nameting (follow-up)}

Volgens Twentyman en zimmering (1979) ls het schamel gestela met de duurzaamidid van effecten, bewerkstelligd door scciale vaardigheidstheraplean. Follow-up studies tonen aan dat aanvankelijke resultaten na verloop van tijd vaak geheel of gedeeltelijk extingeren.

In 5.3.4 en 5.4.4 1s beschreven welke programa-kenmerken speciaal gericht zijn op bevordering van de duurzaanheid van de gedragsverandering c.q. op versterking van de verhoogde competentie-verwachtingen. on vast we kumen stellen of de interpersoonlijke vaardighelasthexapleën inderdaad duwrzame effecten teweeg brengen zijn een aantal nametingen herhaald na een intervalperiode van ongeveer een jaar. Daaxtoe zijn alle ex-deelnemers, waarbij nagenoeg complete nametingen werden verzameld in de periode januari tot me 1. 1980, in maat en apri1 1981 uitgenodiga voox een follow-up interview. Het betreft 30 clienten en 41 deelnamen.

Deze herhaalde nameting kan niet opgevat worden als een follow-up meting in de strikte zin van een herhaalde meting na een intervalperiode zonder interventie. Alle deelnemers aan vaardigheldstherapie èn gaan inmers na afloop terug naax hun verwijzer en hoofibehandelaar. van deze behandelears wordt juist verwacht dat zij een positieve inwloed uitoefenen op handhaving en versterking van de gedragsverandering. of, in welke mate en op welke wijze behandelaars zich van deze taak kwlyten 19 niet onderzocht. Een tweede nameting na een rulme periode kan echter wel. inzicht geven in de uiteindelijke resultaten van de gecomblimeerde inspanningen eventueel aanlelalng geven tot bijstelling vain verwachtingen of wexkwijzen.

Ith de tweede nameting zijn nast de SE-schaal en de Algemene Klachten Lijst tevens ale Skims en Speclifieke Klachten Lijsten afgenomen, die bij de betreffende client ook reeds in de (eerste) nameting waren afgenomen. 


\subsection{Datavexwerking en resultaten}

Bij de beschouwing van de resultaten van de interpersoonlijke vaardigheidstherapieên mag het eerdergenoemde pexcentage non-participatie. naar schatting $20 \%$, niet onvermeld blijven. Hoewel dit een "heel normal." verschijnsel is dat ook en in dezelfde mate optreedt onder andere cliëntencategorieën en in andere typen contacten tussen RIAGG-werkexs en cliēnten, moet er toch rekening mee worden gehowden dat een deel. van de non-participatie te wijten zal zijn aan teleurstelling en/of angst. Teleurstelling ondat men een andere worm yan hulp krljgt aangeboden (opgedrongen?) dan men verwacht: angst ondat de vaardigheidstherapieèn "eisen' stellen waaraan sommige deelnemers menen niet te kunnen voldoen. Dergelijke reacties kunnen zowel vóbr als na kennismaking met de vaaraigheidstherapieën optreden.

Het aantal 'wegblijvers", mensendiebij de eerste bijeenkomst van de groep niet komen opdagen, wordt overigens vele malen groter geschat dan het aantal 'afhakers", deelnemers die na een of twee bijeenkomsten niet meer verschijnen.

De experimentele metingen hebben betrekking op de clienten die 3 of 4 groepsbijeenkomsten hebben meegemaakt.

\section{3 .1 gefecten op (on) vaardigheld $A$}

Met de A-Skims zijn 117 experimentele en 50 controle-(woor en na-) metimgen verzamela. De metingen zijn als volgt ovex de diverse vaardigheldstherapje ên en Skims verdeeld: zie tabel 7.1 .

De kleine aantalien controle-metingen laten niet toe për varalgheda te berekenen of deelname aan het betreffende therapieprogramma leldt tot meer vaardigheidstoename dan de controle-conditie. Deze berekening is wel mogelijk met betrekking tot de skims 1 en 8 , ondat bij deze skins wel voldoende controle-metingen beschikbaar zijn. 


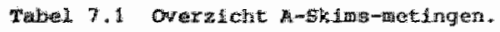

\begin{tabular}{|c|c|c|c|}
\hline & & W-Exp & $w=\operatorname{cont} x$. \\
\hline \multirow{2}{*}{\multicolumn{4}{|c|}{ Ward fighedid cod. }} \\
\hline & & t. 5 & 10 \\
\hline & 2 & 20 & 1 \\
\hline & 3 & 16 & 2 \\
\hline & 4 & 15 & 6 \\
\hline & 5 & 22 & 5 \\
\hline & 6 & - & $\propto$ \\
\hline & 7 & - & - \\
\hline & 8 & 24 & 22 \\
\hline & 9 & 5 & 4 \\
\hline pratad & & 117 & 50 \\
\hline
\end{tabular}

Figur 7.1 heeft betrekking op vaardigheid 1: een prattje maken.

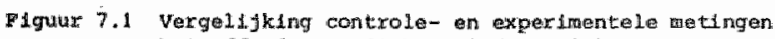
betreffende vaardigheia 1 (Skim 1A)
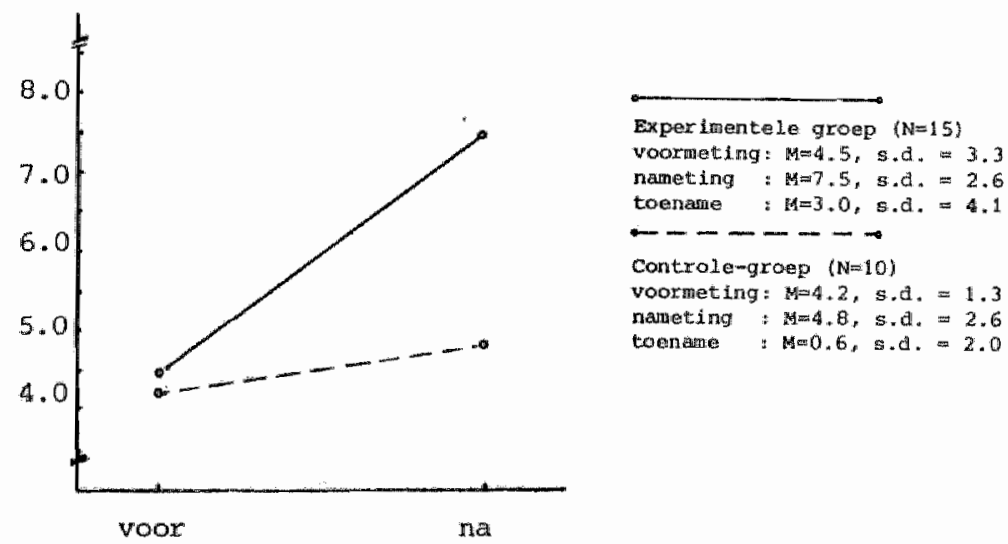

Deelnemers an een vardigheldstherapie "een praatje maken "vertonen een toename in de betreffende skim-score (minimum 0 , maximum $14 j$, die significant grotex $1 \mathrm{~s}$ dan de toename bij de controlegroep: $T=1.95$. p-eenzljalg $=.03$. Beide groepen verschilien niet op de voormeting: $\mathrm{T}=.35, \mathrm{p}=.73$. 
In figuur 7.2 wordt eenzelfde vergelijking gemaakt m.b.t. vaardigheid 8: opkomen voor je mening.

Filguiu 7.2. Vergelijking experimentele en controle-groep betreffendie warardigheld o (sking ea)
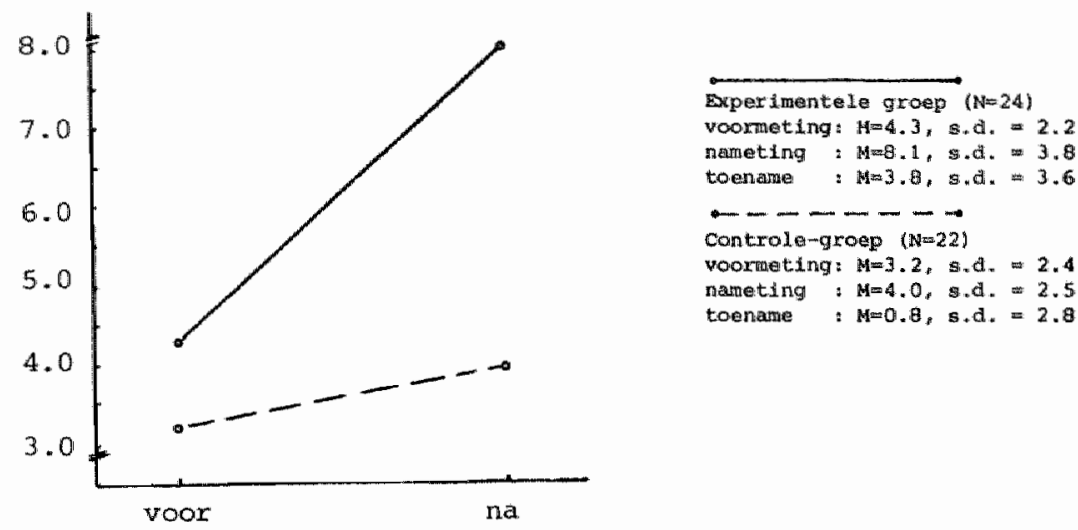

Skin 8 A heeft een mininum-score van 0 en een maximum-score van 14 . De expermentele groep verschilt niet significant van de controle-groep op de voormeting: $T=1.58, p=.12$. De toename van de skim-3core 15 in de experimentele groep significant hogex dan in de controle-groep: $1=3.00, p$-eenzijaig $=.002$.

verdere vergelijkingen tussen afzonderlijke expeximentele en controle-groepen is niet mogelijk. Om toch een maximaal gebruik te maken van de verzamelde data zijn over alle experimentele en controlemgropen groter dan 10 t-toetsen voor herhalde metingen uitgevoerd lale tabel 7.2).

Van de controle-groepen blijken de Skim-scores bij de nameting enigszins, doch statistisch niet significant, hoger te liggen dan bif de voormeting. De 6 experimentele groepen vertonen alle stijgingen. De kans dat deze stijgingen op toeval berusten varleert van 6 tot 1. 


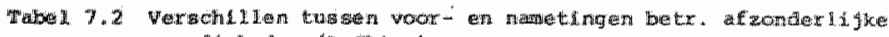

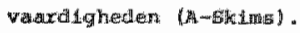

\begin{tabular}{|c|c|c|c|c|c|c|c|c|c|c|}
\hline & & \multirow[b]{2}{*}{ N } & \multicolumn{2}{|c|}{ 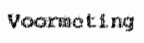 } & \multicolumn{2}{|c|}{ Wametelng } & \multicolumn{2}{|c|}{ Toentamis: } & \multicolumn{2}{|c|}{ 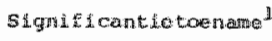 } \\
\hline & & & $M$ & 8. & $n$ & 到。诸。 & H. & to. & $\mathbb{T}$ & $p$ \\
\hline \multirow{2}{*}{\multicolumn{2}{|c|}{$\begin{array}{l}\text { Conte. } \\
\text { gxtal i }\end{array}$}} & 10 & 4.2 & 1.3 & 4.8 & 2.6 & 0.6 & 2.0 & 0.94 & .37 \\
\hline & & 22 & 3.2 & 2,4 & 4.0 & 2.5 & 0.8 & 2.0 & 1.37 & .19 \\
\hline \multirow{7}{*}{\multicolumn{2}{|c|}{$\begin{array}{l}\text { grapep } \\
\text { groep }\end{array}$}} & & & & & & & & & \\
\hline & & 15 & 4.5 & 3.3 & 7.5 & 2.6 & 3.0 & 4.1 & 2.85 & .01 \\
\hline & & 20 & 7.0 & 3.5 & 6.4 & 3.1 & 1.4 & 2.8 & 2.27 & .02 \\
\hline & & $1 s$ & 3.8 & 3.1 & 6.3 & 3.2 & $2, \frac{5}{3}$ & 2.4 & 4.18 & .001 \\
\hline & & 15 & 5.3 & 2.3 & 5.9 & 1.6 & 0.7 & 1.6 & 1.63 & .06 \\
\hline & & 22 & 3.2 & 3.0 & 4.6 & 2.9 & 2.4 & 3.0 & 2.11 & .02 \\
\hline & 8 & 24 & 4.3 & 2.2 & 8. 1 & 3.8 & 3.8 & 3.6 & 5.09 & .001 \\
\hline
\end{tabular}

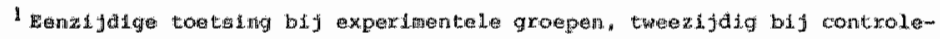
gromen.

Daar de A-Skims onderling hoog correleren (zie 6.1.3) is samenwoeging van de verzamelde data geoor loofd. Daartoe dienen de Skins-sciores dan wel gestandaardiseerd te worden. Deze operatie geeft extra informatie omdat daardoor alle cases in de berekeningen kumnen worden meegenomen en niet slechts bovengenoemde subgroepen.

Na standaardisatle blijkt (zle tabel 7.3) dat de A-vaaraigheid toeneemt in zowel de experimentele als in de controle-groep, dach dat die toename significant groter is in de experimentele groep.

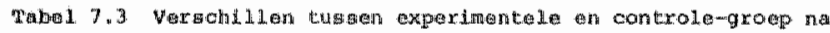

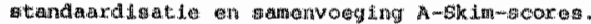

\begin{tabular}{|c|c|c|c|c|c|c|c|}
\hline & \multirow[b]{2}{*}{$N$} & \multicolumn{2}{|c|}{ foctnarne } & \multicolumn{2}{|c|}{ Ignificant te toename } & \multicolumn{2}{|c|}{ Vierschiltzoentime } \\
\hline & & M & a. & $\mathrm{w}$ & $p$ & $\mathbb{T}$ & $\mathrm{p}$ \\
\hline Exp.groep & 117 & 0.89 & 1.34 & 7.16 & .000 & 2.90 & $.003 i$ \\
\hline contr. grosp & 50 & 0.31 & 1.11 & 1.95 & .056 & & \\
\hline
\end{tabular}




\section{3 .2 Effecten op lonlvaardigheid B}

Met B-Skims zijn 81 experimentele en 34 controle-metingen verzaneld (zie tabe1 7.4 ).

Tabel 7.4 Oweratcht B-5kjus-metingen.

\begin{tabular}{|c|c|c|}
\hline & y-exp. & N-contr. \\
\hline \multirow[t]{4}{*}{ Varaxigheid } & 20 & 1 \\
\hline & 15 & 6 \\
\hline & 22 & 5 \\
\hline & 24 & 22 \\
\hline Total & 81 & 34 \\
\hline
\end{tabular}

De omvang van de diverse groepen is van dien aard dat slechts skim 8 in aanmerking komt voor een aparte vergelijking tussen de experimentele en de controle-groep.

In Iiguur 7.3 is te zien aat de experimentele groep slechts een zeer geringe stijging vertoont op Skim 8 , die een score-bereik heeft van 0 tot 12 . Toch verschilt de score-toename van de experimentele groep significant van die van de controle-groep $(T=1.78$, p-eenzijdig $=.04)$. Ex is geen verschil tussen belde groepen op de voormeting $(\mathbb{T}=.45$, $p=.65)$. Figuux 7.3 Vergelijking experdmentele en controle-groep betreffende
vaardigheid 8 (Skim $8 \mathrm{~B}$ )
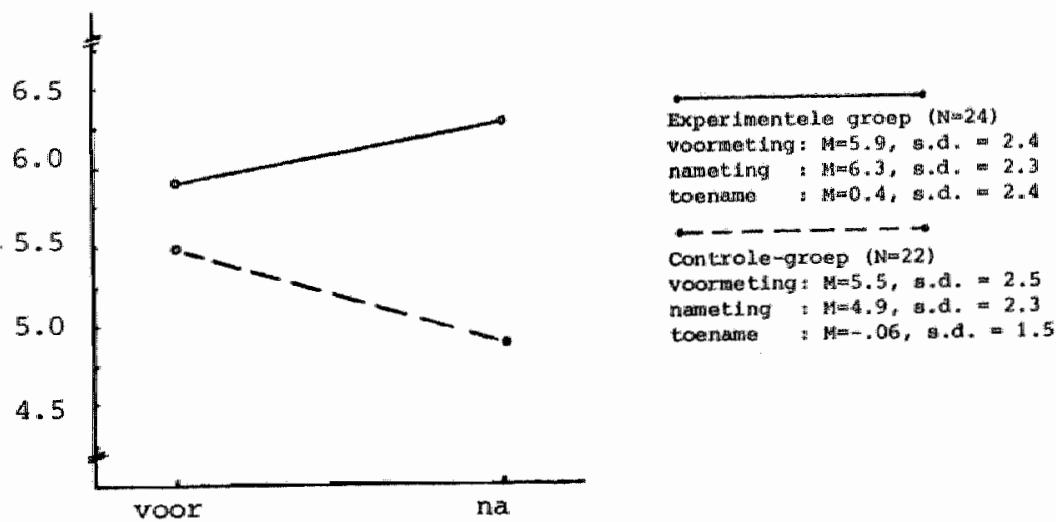
Tabol 7.5 toont de verschillen tussen voor-en nametingen voor de subgroepen grotex dan 10.

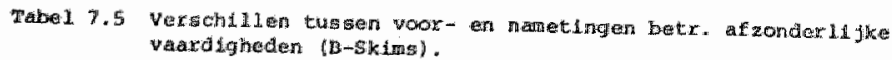

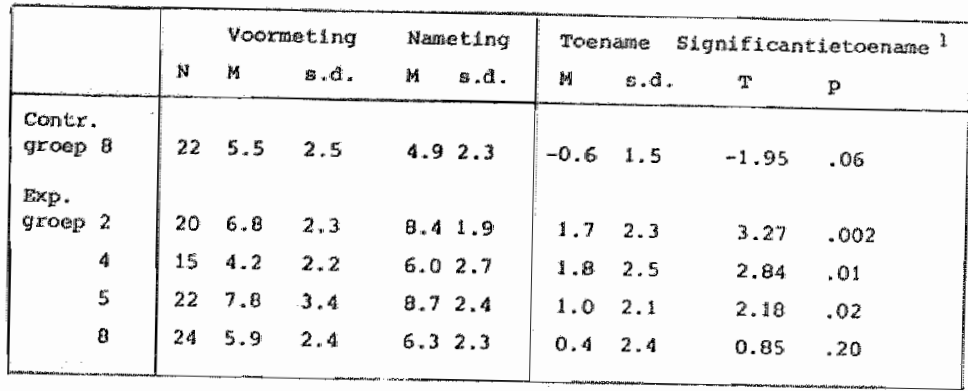

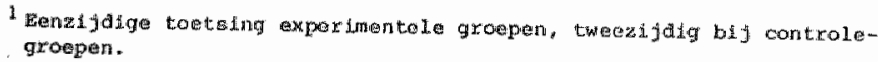

De kans dat de daling valn de controle-groep op Skim 8B op toeval berust is 6\%. Van de 4 experimentele groepen vertonen ex 3 een statistisch significante toename in B-Skim-scores, terwijl de vierde betrekking hebbend op "opkomen voor je mening") niet significant stijgt. Samenvoeging van alle B-Skims-gegevens na standaardisatie laat zien dat controle-metingen niet significant verschililen op de twee meettijdstippen, terwijl de experimentele conditie tot gratexe B-vaaraigheld leidt (zie tabel 7.6). 
Tabel 7.6 Verchilden tussen experimentele en controllewgroep, na stranciardisatie en samenvoeging 3 -skin-scores.

\begin{tabular}{|c|c|c|c|c|c|c|c|}
\hline & \multirow[b]{2}{*}{ N } & \multicolumn{2}{|c|}{ Toerinariate } & \multicolumn{2}{|c|}{ Significartie toename } & \multicolumn{2}{|c|}{ Verschiltoenande } \\
\hline & & $M$ & s.. & $\mathrm{T}$ & $P$ & $\mathrm{~T}$ & $p$ \\
\hline $\begin{array}{l}\text { gxp. groep } \\
\text { comer. groep }\end{array}$ & 81 & $\begin{array}{r}0.47 \\
-0.01\end{array}$ & $\begin{array}{l}0.96 \\
0.68\end{array}$ & $\begin{array}{l}4.34 \\
0.82\end{array}$ & $\begin{array}{r}.000 \\
.42\end{array}$ & 3.54 & .001 \\
\hline
\end{tabular}

\section{3 .3 Effecten op specifieke klachten}

De Specifieke Klachten Lijst is tweemal afgenomen bij 191 deelnemers. ook hier gelat dat een individuele deelnemer meemalen als proefpersoon in het bestand kan voorkomen.

Van deze 191 deelnemers hebben er 157 in de interval-periode deelqenomen aan een interpersoonlijke vaardigheidstheraple; zij vomen de experimentele groep. De owerige 34 hebben in de intervalperiode 'op de wachtlijst gestaan" voor deelname en vormen de controle-groep. De experimentele groep heeft 337 klachten ingebracht, de controle-groep 77. Figuur 7.4 laat het verloop van deze klachten zien.

Figuur 7.4 Reducte spelffeke klachten; klacht = case
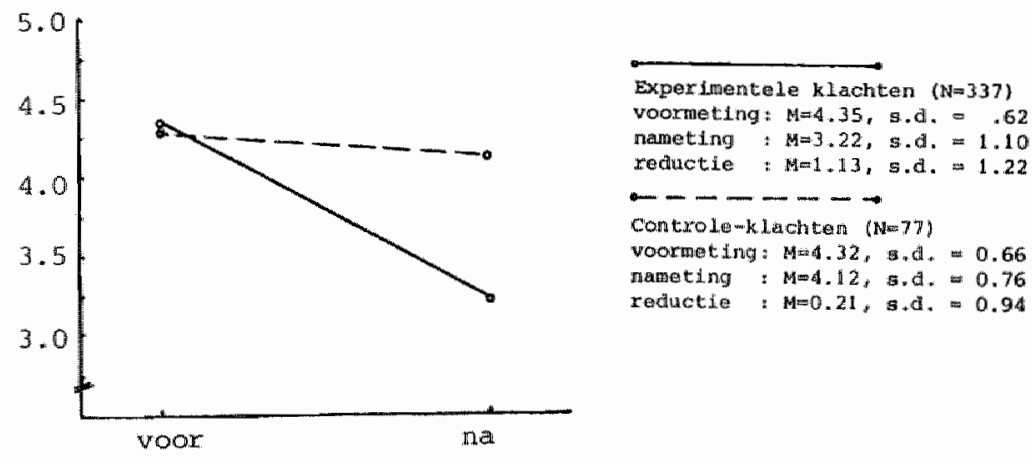

De vaardigheidstherapieen bewerkstelligen een reductie in specifleke klachten, die significant groter is dan die bij de controlemconditie: $\mathbb{T}=7.36, \mathrm{p}=.000$. De experimentele en controle-groepen verschillen niet op de voormeting. 
Aangezien de verbetering in de expertmentele groep wel eens medebepad Lo kan zijn door specifiteke vaardigheden, is een variantieanalyge uitgevoerd met "vaaraigheld" als tussen-groepen-factor. Alle 9 vaardigheden $z i j n$ in het bestand vertegenwoordigd. De interactie tusseri interval $x$ varaigheid blijkt echtex rilet sigmilicant $\left(F^{*}=1.20\right.$, $\mathrm{p}=0.30)$.

Deelnemers hebben 1,2 of 3 klachten kunnen inbrengen. Het boven weergegeven resultabt, gebaseerd op klacht = case, houdt geen rekening met het feit dat sommige deelnemers driemal zoveel gewicht in de schaal leggen als andere. Door pèr deelnemer één score te bepalen door midaling van de ernst-scores wan de ingebxachte klachten, krijgt elke deelnemer dezelfde invloed op het resultat (zie figuur 7.5)

FIgurr 7.5 Reducte speciflek klachten, deelnemer case
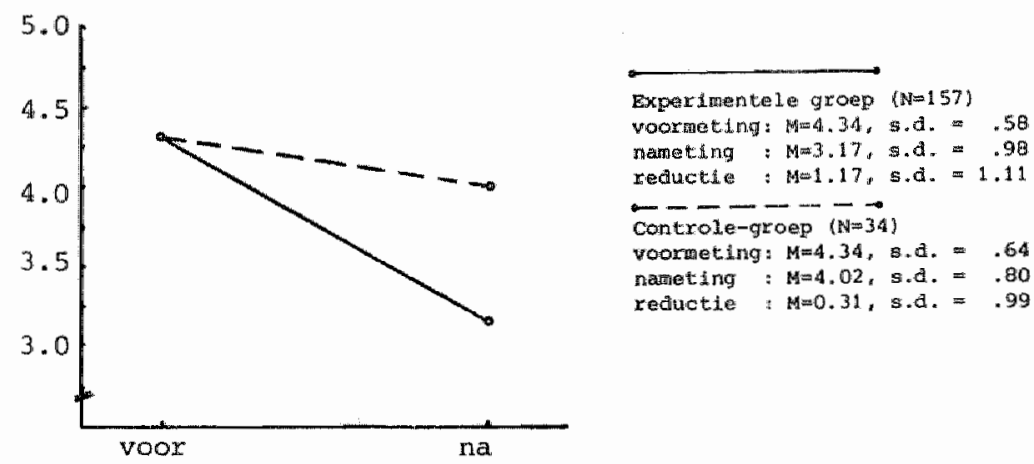

De experimentele groep vertoont een reductie in specifieke klachten die signiftcant groter is dan die in de controle-groep: T $=4.16, p=.000$. Baide groepen scoren exact even hoog op de voormeting.

ook de door de deelnemers zelf-ervaren-verandering valt zowel op klachten- als op deelnemers-niveau ult in het voordeel van de vaardigheidsthexaplesn: zie tabel 7.7 .

De correlatie tussen de berekende verandering (het verschil tussen ermst-scores op voor- en nametingl en de door clienten gerapporteerde verandexing is .58 (Pearson, $p=.001, N=414$ ). 


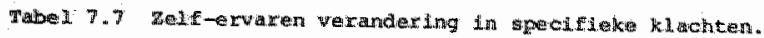

\begin{tabular}{|lc|ccccc|}
\hline & s.d. & & s.d. & af & d.f \\
\hline Contr. klachten & 77 & 0.22 & 1.11 & & & \\
\hline Exp. groep & 157 & 1.87 & 1.69 & & & \\
Contr. groep & 34 & 0.11 & 0.94 & 8.31 & 96.05 & .000 \\
\hline
\end{tabular}

\subsubsection{Effect_op zelfwaardering}

Voor - en nametingen van zelfwaardering met de SE-schaal zijn verzameld bij 166 deelnemers en 26 controle-personen. De experimentelle groep blijkt significant meer toe te nemen in SE-scores dan de controlegroep: $T^{2}=2.40, \mathrm{p}=.02$ (eenzijaig) (zie figuur 7.6 ).

Flqunu 7.6 vergelijking experimentele en controle-groep, sE-schaal
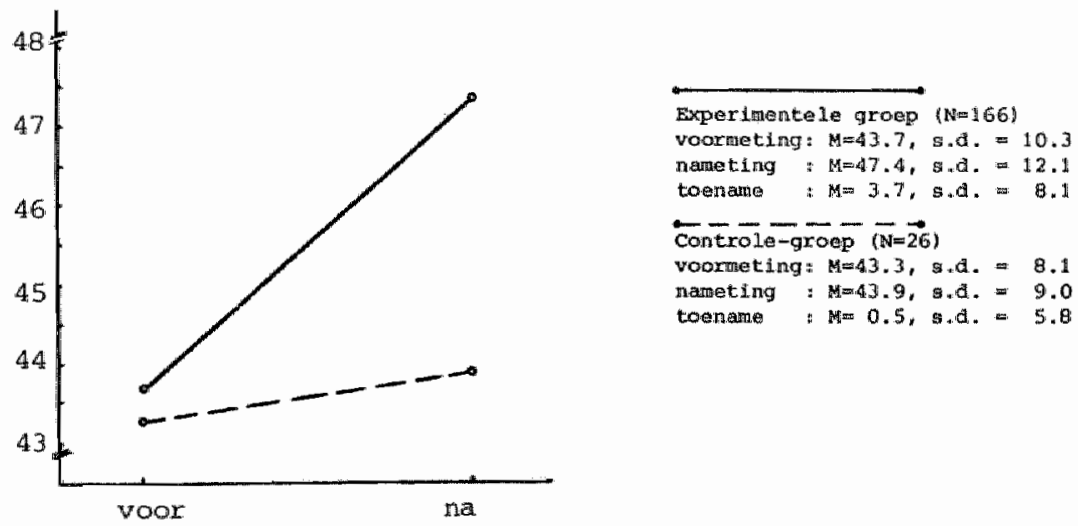

Het verschil tussen belde groepen op de voormeting is niet significant, evenmin als de SE-toename van de controle-groep.

De 166 deelnamen hebben betrekking op steeds én vaardigheiastheraple. Tenelnde vast te stellen of de specifleke vaardigheid een rol speelt in de SE-toename, is een variantie-analyse voor herhalda metingen uitgevoerd met de vaardigheid als tweede factor. Acht van de negen vaardigheden zijn in het databestand vertegenwoordigd, warbij de omvang van 
de subgroepen varleext yan 9 tot 33 . Uit de variantie-analyse blijkt dat ex geen signiflcant verschil is tussen de 8 subgroepen: $F=0.51$, $\mathrm{p}=.83$.

De toename van de zelfwaardering is dus niet afhankelijk van de vaardigheld die op het programa stat.

\subsubsection{Effecten op algemene klachten}

Die experinentele groep, 110 deelnemers, heeft 232 algemene klachten ingebracht; de 17 controle-groeppersonen hebben 34 klachten genoend. De ernst van de 'experimentele klachten' blijkt meex af te nemen dan de exnst wan de 'controle-klachten': $T=2.58, \mathrm{p}=.01 \quad(2-z i j \mathrm{~d} i \mathrm{~g})$ (zie figuar 7.7).

De verschillen tussen beide groepen op de voormeting zijn niet significant.

Flguur 7.7 keductie algenene klachten; klacht w case
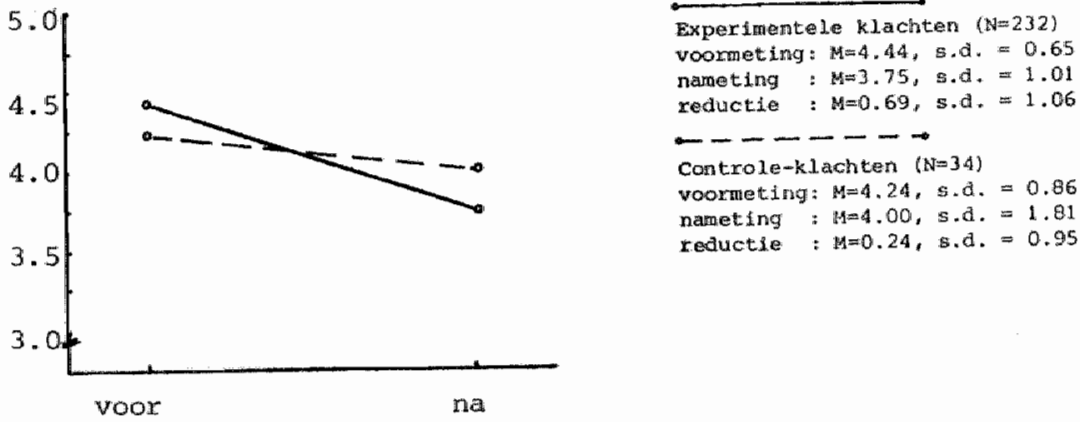

De specifieke doelvaardigheid zou van invloed kunnen zijn op de mate waxin experimentele klachten verbeteren. Die mogelijkheid is getoetst met behulp van een varlantie-analyse. Het verschil tussen de 9 groepen blijkt niet sigmificant.

Als per deelnemer een gemiddelde ernst-score wordt gepaald ontstaat een ander resultat (zie figuur 7.8 ). 

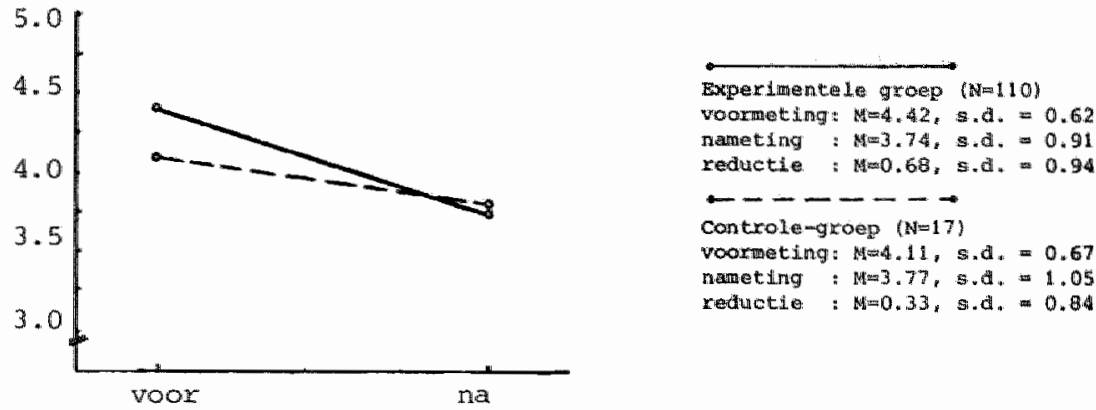

Het verschil tussen de experimentele en de controle-groep op de voormeting is significant op 10 -niveau $(T=1.77, p=.09)$, en de reductie van de ernst-scores is in de experimentele groep niet groter dan in de controle-groep $(\mathrm{T}=1.53, \mathrm{p}-2-\mathrm{zijdig}=0.14)$.

Het oordeel van de deelnemers zelf over de mate waarin hum klachten zijn verbeterd of verslechterd, valt eveneens licht in het voordeel van de experimentele conditie uit; zlie tabe 7.8 .

De vexschilien zijn echter niet significant op 5\%-niveau.

De Pearson-correlatie tussen de berekende verandering en de door cliënten exvaren verandering in algemene klachten is . $51(\mathbb{N}=266$, $\mathrm{p}=.001)$.

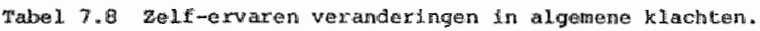

\begin{tabular}{|c|c|c|c|c|c|c|}
\hline & $N$ & M & s.a. & $\mathrm{x}$ & $d f$ & $p-2-2 I J d L$ \\
\hline $\begin{array}{l}\text { Exp. Nlachten } \\
\text { Conter. klachten }\end{array}$ & $\begin{array}{l}232 \\
34\end{array}$ & $\begin{array}{l}1.40 \\
0.76\end{array}$ & $\begin{array}{l}2.10 \\
1.94\end{array}$ & 1.76 & 45.08 & .09 \\
\hline $\begin{array}{l}\text { Wwe. groop } \\
\text { contr. gromep }\end{array}$ & $\begin{array}{l}110 \\
17\end{array}$ & $\begin{array}{l}1.49 \\
1.22\end{array}$ & $\begin{array}{l}2.08 \\
2.25\end{array}$ & 0.50 & 125 & .62 \\
\hline
\end{tabular}




\section{3 .6 EfEecten var meerare deelnamen}

Cliênten worden in de regel aangenela woor 2 à 3 vaandigheden, een enkele maal voor meer.

Tot nu toe zijn de thexaple-effecten van deelname aan eén vaardigheidstheraple beschreven. Of het dearbly on een tweede of een derde deelname ging, is bulten beschouwing gebleven.

De vraag dringt zich echter op of het terecht is dat clienten aan meerdere vaardigheldstherapieên deelnemen. Draagt een tweede of een derde dewname, afgezien van het feit dat men zich nog een vaardigheid eigen makt, verder bijl aan de algehele toestand van de client?

Het verloop van de twee a-specifieke weten, zelfwardering en algemene klachten, kan ten aanzien van dit vraagstuk ultsluitsel geven. De nameting van de eexte deelname fungeext namelijk tevens als voormeting voor de tweede, de nameting van de tweede als voormeting voor de derde deelname, etc.

Tabel 7.9 toont het resultaat van een variantie-analyse voor herhaalde SE-metingen met 'volgorde van deelname' als toegevoegde factor. Vervolgdeelnamen blijken tot verdere toename van de zelfwardering te leiden, in dezelfde mate als eerdere deelnamen.

Tabel 7.9 se-toenamen bij achtereenvolgende demlinam.

\begin{tabular}{|c|c|c|c|c|}
\hline & \multirow[b]{2}{*}{$N$} & \multicolumn{2}{|c|}{ SE-toennat } & \multirow{2}{*}{$\begin{array}{l}\text { Verschil kusigen } \\
\text { groepen }\end{array}$} \\
\hline & & $M$ & s.d. & \\
\hline Eerste deolname & 106 & 3.9 & 8.8 & \\
\hline 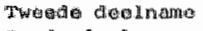 & 36 & 2.4 & 6.1 & $F=0.45 i$ \\
\hline Dende dest Inema & 14 & 3.5 & 6.3 & \\
\hline Vtorch diandine & B & 6.4 & 10.5 & $p=\quad .77$ \\
\hline Vijede diecel nane & 2 & 5.0 & 0.0 & \\
\hline A11 thell mamen & 166 & 3.7 & 8.1 & \\
\hline
\end{tabular}

Dewelfde bewerking is uitgevoerd op de algemene klachten. Eenmaal geformuleerd, tijdens de eerste voometing, zijn deze klachten inhoudelifk hetzelfde gebleven. Tabel 7.10 laat zien dat iedere nieuwe deelname opnieuw en in dezelfde mate bijjaragt tot verdere reductile van algemene klachten, zowel op klachten- als op deelnemex-niveau. 
Tibel 7.10 Refuctie algemene klachten bu achereenwolgende deelnamen.

\begin{tabular}{|c|c|c|c|c|c|c|c|c|}
\hline & \multicolumn{4}{|c|}{ Klacht $=$ coset } & \multicolumn{4}{|c|}{ Deelnewer ense } \\
\hline & \multirow[t]{2}{*}{$\mathrm{M}$} & \multicolumn{2}{|c|}{ reductie } & \multirow{2}{*}{ yergchils this- } & \multirow[t]{2}{*}{$\mathrm{N}$} & \multicolumn{2}{|c|}{ recuctue } & \multirow{2}{*}{$\begin{array}{l}\text { wersicht tus - } \\
\text { sen groepen }\end{array}$} \\
\hline & & 4 & 5.0 & & & $m$ & 5. & \\
\hline Eexste deselnawo & 128 & 0.67 & 1.13 & & 6.3 & 0.66 & 1.02 & \\
\hline Twede deelrame & 58 & 0.64 & 1.00 & $F=1.09$ & 26 & 0.64 & 10.90 & $=0.39$ \\
\hline Derde deand name: & 24 & 1.13 & 11.08 & $p=.37$ & 10 & 1.03 & 0.92 & $D=.86$ \\
\hline Viexde deolname & 17 & 0.47 & 10.72 & & 8 & 0.50 & 0.46 & \\
\hline Viffide deelname & 3 & 0.33 & 10.58 & & 2 & 0.50 & 0.71 & \\
\hline Zesde deedname & 2 & 1.00 & 0.00 & & 1 & 11.00 & 0.00 & \\
\hline Totan & 232 & 0.69 & 1.06 & & 110 & 0.64 & 0.94 & \\
\hline
\end{tabular}

\section{3 .7 Effecten na een Jaar}

Ongeveer een jaar na hun laatste deelnare zijn 30 ex-deelnemers geselecteerd voor een tweede nameting $(z 1 \cdot) 7.2 .4)$. In cen geval is van een uitnodigting afgezien; deze cliënt bleek op een psychiatrische afdeling te zijn opgenomen en de behandelaar was van oordeel dat een interview niet mogelijk was ('te psychotisch'). Een andexe cllänte bleek onbereikbaar: twee schriftelijke contactnamen en een huisbezoek bleven zonder resultaat. Drie cliënten wejgerden aan het gesprek deel te nemen; als redenen werden genoemd:

- tijagebrek, mede door studie-achterstand

- in behandeling bij zenuwspecialist

- recent huwelijksfeest en sterfgeval in de familie, bang dat het werleden weer boven komt, moet bovendien 3-maal per week naar het ziekenimis in verband met lichamelijke klachten.

Bij deze 5 clieuten, $1 / 6$ van de geselecteerde groep, konden de nametingen dus niet hexhada worden. Van 3 van hen, 10: van de geselecteerde groep, kan gezien hun (verdere) zlektegeschiedenis angenomen worden dat zij uiteindelijk geen baat hebben gehad bij de behandeling in het RIAGG, inclustef de deelname an de intexpersoonliljke vaaxdigheldstherapleän.

Bif de 25 wel-bexeikte ex-deelnemers heeft een herhaling van de nameting plaatsgevonden. Bij 7 van de 25 , die tweemulal in het experimentele databestand vertegenwoordigd waren, zijn 2 skims en 2 specifieke 
Wachten Lijsten afgenomen. In tabel 7.11 worden de "aanvarkelijke mametingen" vergeleken met de 'follow-up-metingen".

Teraljl de sE-scores stabiel blijven, nemen de gestandardiseerde Skin-bcores verder toe en treedt verdere verbetering op van specifieke en wan algenene klachten.

Tabel 7.11 Vorgelifklng tusen nam follow-upmetingen.

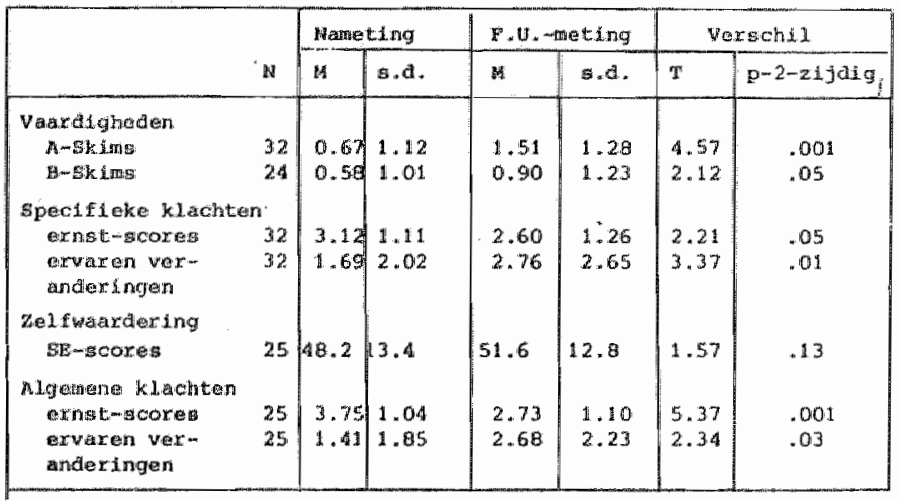

\subsection{Discussie, conclusies, samenvatting}

op gezette tijân zljn metingen verricht bij cliënten, verwezen voox interpersoonlijke vaarajgheldstherapieën. Deze metingen hebben betrekking op uiteenlopende uitkomstoriteria om de vxaag naar de effectiviteit van de ontwikkelde therapie-programa"s vanuit meerdere lmualshoeken te kunnen beantwoorden.

\subsubsection{Vexanderingen in A-en B-vaardigheden}

Uit de berekeningen in 7.3 .1 blijkt dat deelname aan interpersaonlijke vaduigheidstheraple ${ }^{n}$ leidt tot vergroting $v$ an vaardigheden van het type A. Bij clienten op de wachtlijst blijkt echter eveneens verbetering op te treden, zij het in mindere mate. Voor deze clienten geldt dat zij tot het inzicht gekomen $\mathrm{c} . \mathrm{q}$. gebracht zijn dat het wenselijk is dat 
zij zich minder onderdanig, bang, subassertief leren gedragen in interpersoonlijke situaties. Wellicht bewerkstelligt dit inzicht in de wachtpexiade reeds enige gedragsverandering. De vraag blifft in welke mate deze "spontane" verbetering zich doorzet in langere wachtperioden.

Met betrekking tot onvaardigheaen-type-B treedt gë́n verbetering op in de wachtpexiode. Het blijkt zelfs dat deelname aan een vaaraigheids therapie "opkomen voor je mening" niet leidt tot een significante toename van de B-vaardigheid, doch de deelneners behcedt voor de versiechtering die optreedt in de controle-groep. zijn de proefpersonen van de controle-groep zich tijdens de wachtperiode in toenemende mate gaan realiseren hoe ongedurig-agresslef zij optreden, of hebben hun pogingen on op eigen kxacht minder onderdanig/bang op te treden geleid tot vinniger gedrag ten opzichte van anderen? Waarschjjnlijk moeten de veranderingen op de A- en B-Skims in onderlinge samenhang worden bezien. Tabel 7.12 toont de gestandaaxdiseerde verschil-scores tussen voox- en nametingen (ruwe verschil-scores gedeeld door standaardafwijking bij) de voometing) op A- en B-Skims. De competentie van de 24 deelnemers aan de vaardigheldstheraple 8 , opkomen vaor je mening, blijkt relatlef fors toe te nemen op de A-SkLns, doch niet op de B-Skims. De 22 deelmemers aan vardigheidstherapie 4 , reageren op kwaadheid, stijgen qua competentie enigszins op de A-Skims, maar nadrukkelijker op de B-Skins.

Tabe 7.12 Gemidelae gestandaardiseerde verschilgcones van deelneners op $A$ - en B-Sklims .

\begin{tabular}{|c|c|c|c|}
\hline Warch ighete & $N$ & Toenas $A$-Skdus & Towname B-skinss \\
\hline 1 & 15 & 1.13 & - \\
\hline 2 & 20 & 0.41 & 0.72 \\
\hline 3 & 16 & 0.79 & - \\
\hline 4 & 15 & 0.28 & 0.85 \\
\hline 5 & 22 & 0.49 & 0.29 \\
\hline 8 & 24 & 1.64 & 0.17 \\
\hline
\end{tabular}


Varalgheden zoals ludstexen (2) en utten van kwadheid (5) blijken zowel op de $\mathbb{A}$ - als op de $B$-dimensies toe te nemen. Var de vaardigheden 1. 3 en 9 bestait geen B-Skim, zodat de betreffende therapie-programa "s hun eventuele effectiviteit met betrekking tot de bestrijaing van een B-type-onyaardigheid niet hebben kunnen bewljzen. Het komt ons voox dat de vaardigheldstherapieen effectief zijn in het vergroten van befde typen vardigheden, en dat de gevorden verschillen in vaardigheldstoename voor rekening komen van de deelnemers. Sommige clienten nemen deeI an een vardigheidstherapie met het oog op onvaardigheidtype-A, anderen vanwege onvardigheid-type-B. Ook "dubbele doelsteldingen" zijn in deze mogelijk; de belde typen (onvaardigheld zijn imuers onafhankelijk van elkaar.

De correlaties tussen voormetingen en vardigheidstoenamen in de experimentelle groep, bij de A-Skims - 46 en bij de B-Skims - .54, laten weliswar inderdaad zien dat de wardigheidstoename groter is naarmate de aanvangsscore lager ligt, doch dit kan ook geilnterpreteerd worden als een artefact: wie lager scoort bij de voormeting kân immers ook meex toenemen.

Een extern critexium om te bepalen of een client-praefpersoon deelneemt ter vergroting van vaardigheld $\mathrm{A}$ of $\mathrm{B}$ is niet voorhanden, zodat uitsplitsing van deelnemers in een $A$ - en een B-groep niet mogelijk is. Het lijkt wenselijk in de toekomst bij pre-metingen tevens informatie te verzamelen waaruit conclusies getrokken kunnen worden ten aanzien van het type onvaardigheid dat bij de betreffende cliënt in het geding

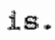

\section{4 .2 Doe 1 -gebonden resultaten}

De interpexsoonlijke vaardigheldstherapiee groten a.e. de problemen die kansarme (Ijbo-) clienten hebben met bepalde interpersoonlijke activiteiten te verminderen of op te heffen. De Skims- en Specifieke Klachten-metingen kunnen dan ook als doelgebonden (goal-based) beschouwd worden. De bevindingen met betrekking tot beide uitkonsten (zi.e $7.3 .1,7.3 .2$ en 7.3 .3 ) rechtwarardigen de conclusie dat de vaardigheldstherapieen inderdaad aan hun doelen beantwoorden. De niet te verwaarlozen verdere verbetering na een Jaar 
(zie 7.3.7) toont an dat de matregelen, die gedurende en na afloop van de programma's worden getroffen, ter bevordexing wan de duraramheid van de effecten, buitengewoon effectief zijn. Nader ondersoek gericht op identificatie van de meest-werkame sub-matregelen is inmiddels ter hand genomen.

\subsubsection{Doel-vijye resultaten}

De perioden warin clienten door hoofdbehandelaars worden 'uitbesteed' voor deelname aan interpersoonlijke vaaxdigheidstherapieen kumnen ook worden aangewend om de individuele behandeling van hoofdproblemen voort te zetten. Hoe meer deze hoofdproblemen verweven zijn met bepaalde vaardigheidstekorten hoe meer een verwijzing naar vaardigheidstherapieän op zijn plaats is. Een ondexzoek naax de effecten van vaardigheidstherapleën op 'algemene klachten' kan dan ook tevens gezien worden als een onderzoek naar de kwaliteit van verwijzingen. Howel de bevindingen in deze niet eenduldig zijn (zie 7.3.5; op klachtenniveau zijn de vaardigheldstherapleẻn superieur aan de controleconditie $=$ voortzetting individuele behandeling, terwijl ex op deelnemers-niveau geen verschil tussen beide condities wordt aangetoond) blijken de vaardigheidstherapieên significant bij te dragen aan reductie van deze algemene klachter, zowel op klachten- als op deelnemers-niveau. Voortzetting van de individuele behandelingen na afloop van deelname aan de interpersoonlijke vaardigheldstherapleën leidt weliswaar tot verdere verbetering doch niet tot opheffing van de algemene klachten (2ie $7.3,7)$. De vaardigheidstherapieën blijken tevens, ongeacht de doelvaardigheid, te lelden tot een toename van de zelfwaardering (zle 7.3.4). Bij meerdere deelnamen $(z i \in 7,3.6)$ blifft dit gevoel van elgenwarde cumulatlef toenemer.

Buj 2 à 3 deelnamen betekent dat een toename met 6 a 10 punten op de 75-punts-SE-schaal. Deze bevindingen bevestigen veelvuldige uitspraken van cliëten na deelname aan de vaardigheidstherapieen, dat zij "meer zelfvertrowwen" hebben gekregen, wich "zekerder" voelen, zich niet meer 'minder voelen dan anderen', etc.

Uit de tweede nameting (zie 7.3.7) blijkt dat deze toegenomen zelfwazdering zich handhate, doch niet verder toeneent. ook de 
controle-metingen tonen dat indivlduele behandelingen niet leiden tot een hogex self-estem. Ondat ex geen gegevens zijn verzameld met betrekking tot doel, aard en inhoud van de diverse individuelle behandelingsprograma's, kan naar verklaringen slechts gegist worden. Het is niet uitgesloten dat die (toch weer) gezocht moeten worden in paragraaf 1.1 .

\section{4 .4 Samenvatting}

Een viextal criterla is gekozen ter bepaling van de effectiviteit van de interpersoonlijke vardigheidstherapieern voor kansamen. Twee daarwan zijn ontleend aan de doelstelisngen van deze theraple-programma's" de belde andere zijn "doel-vrije" critexia. Een van de doelgebonden en een van de doelvrije criterla zijn bovendien individu-speciflek: zij hebben betrekking op de ernst van door de deelnemer zelf genoende kllachten. De betreffende instrumenten zijn afgenomen bij deelnemers aan de Interpersoonlijke vaardigheidstherapieẻn en bij cliënten aie na verwijzing een wachtperiode doormaken waarin hun hoofdbehandeling doorloopt (controle-conditle). Deelname blijkt in grotere mate tot vaardigheidatoename en reductie van individuele vaardigheidsspecifieke klachten te leliden dan de controle-conditie. In tegensteling tot de controle-conditle leidt de experimentele conditie tot toename van de algemene zelfwaardering. Meerdere deelnamen blijken, gezien de additioneel optredende verbetexing, gerechtvaardigd. De effecten na een jaar tonem een woortgezette toename van vaardigheid en reductie van individuele klachten bij het berelkte deel van de geselecteerde groep. 
NAWOORD

De interpersoonlijke vaardigheidstherapieen voor kansarmen hebben een vaste plaats ingenomen in het geheel van curatieve voorzieningen van de Limburgse RIAGG's.

De gestage groei van het aantal verwijzingen naar deze therapieprograma's gaat gepaard met een geleidelijke toename van het aantal door de projectgroep opgeleide therapeuten.

Het 'Goldsteinproject' is daamee niet beëindigd. Terwijl een serie vaardigheden voor doelmatig (rationeel) handelen op effectiviteit wordt beproefa, zijn thexapie-programma's voor partners en voor cliënten met psychosomatische klachten in ontwikkeling. De belangstelling uit de rest var Nederland en uit Vlaanderen heeft in het afgelopen jaar geleid tot een groot aantal voordrachten, demonstraties en workshops en tot een distributie-systeem voor de ontwikkelde therapeutische hulpmiddelen. Opmerkelijk is de aandrang uit andere sectoren van de geestelijke gezondheidszorg: psychiatrische streekcentra, psychiatrische afdelingen van algemene ziekenhulzen. instellingen voor sociaal-pedagogische (zwakzinnigen-) zorg on consultatiebureau's en klinjeken voor vexslaafden. Terwijl een aantal instellingen wit die sectoren de methoden reeds heeft ingevoerd dn zijn dagelijkse werk, heeft de projectgroep in deze ontwikkeling aanlelding gezien on een breed samengestelde werkgroep te formeren die zich bezig houdt met de problemen die de toepassing van de interpersoonlijke vaardigheidstherapiean bij 'moeilijk lerende clienten" met zich meebrengt. Dearin wordt getracht de protocollen aan te passen aari de kansarmsten onder de kansarmen. 
SAMENVATTING

In het inleidende eerste hoofastuk van dit proefschrift wordt de gebrekkige relatie van de hedendaagse psychotherapie met cliënten ult de lagere sociaal-economische klassen beschreven. Daarbij wordt ingegaan op de diverse pogingen die elders zijn en worden ondernomen om deze ongewenste kloof te overbruggen. Goldstein"s structured learning therapy wordt geintroduceerd als een methodiek die tegemoet komt aan de behoeften en mogelijkheden van clienten uft lagere klassen. Het betreft een kortdurende, directieve wexkwijze, met als hoofdcomponenten modeling, gearagsoefening, bekrachtiging en transfex-training, die gexicht is op het aamleren var vardigheden c.q. uitbrelding van het gedragsrepertolle.

Vergelijkingen tussen bevolkings- en cliënten-registratiegegevens wijzen uit dat onder degenen die zich voor hulp tot de Limburgse Regionalle Instituten voor Ambulante Geestelijke Gezondheidszorg (RIAGG's) wenden zich relatief veel mensen uit lagere klassen bevinden. Geconcludeerd wordt dat operationallsatie en implementatie van Goldm steln's methode in de Limburgse RIAGG's op ziJa plaats is.

In het tweede hoofdstuk wordt nagegaan welke ontwikkelingen de wociale leertheorie de laatste jaren heeft doorgemakt on welke consequenties recente inzichten hebben voor vaardigheldstherapleen, meer specilal. voor de structured learning therapy. Deze ontwikkelingen en inzlchten betreffen voornamelljk de '(her)-onderkenning' van de roll van cognitieve factoren in verklaringsmodelien van gedrag en gedragsverandering. Meer specifiek wordt ingegian op Bandura's self-efficacy theory die persoon- 
11jke verwachtingen van eigen competentie centraz stelt. Deze verwachtingen zijn gebaseerd op een wertal informatie-bronnen, waarvan daadwerkelijik gebleken bekwaameid (performance accomplishment) de mecst invloedrijke is. Geconstateerd wordt dat de structured learning therapy naast respons- en responsuitkomst-informatie ook informatie acincikt relevant voor de ontwikkeling van persoonlijke competentieverwachtingen. Geconcludeerd wordt dat Goldstein's vaardigheidstheraple, geherwardeera in cognitlef sociall-leertheoretisch perspectief, met name door het performance-based karakter van de methode, nog steeds de best denkbare condities schept woor gedragsverandexing in het interpersoonlijke domein.

In hoofdstuk 3 wordt getracht de keuze vam interpersoonlijke vaardigheden, op te nemen in de te operationaliseren therapie-programma's, te onderbouwen. Gekozen wordt voor Leary's "roos" als referentiekader voor het uitgebreide domein van interpersoomlijke gredragswijzen.

Een op dit model gebaseerde uitsprakenlijst, de Interpersonal check List, wordt afgenomen bij een clienten-steekroef. Na controles op het gebrulkte instrument en het exaan ten grondslag liggende model wordt de doelgroep, cliënten uit lagere sociaal-economische klassen, vergeleken met de overige cliënten. Cliënten uit de doelgroep blijken zilchzelf als meer saamhorig te beschrijven. Uit verdere databewerkingen kan worden afgeleld dat 'gredragstekorten' vooral betrekking hebben op leidingnemend en competitieve gedragswijzen, terwijl excessief gedrag voornamelijk betrekking heeft op helpend/verantwoordelijk en teruggetrokken interpersoonlijk gedrag. Uit deze "assessment op groepsniveau" wordt affeleld dat ex in de doelgroep met name behoefte bestaat aan jnterpersoonlijke vaardigheldstherapleën warmee men vaardigheden in het leggen en onderhouden var contacten, het actief reageren op anderen, het omgaan met eigen en andermans kwaadheid, het uitdrukking geven ar menhingen en gevoelens en het ingaan tegen anderen, kan vergroten.

In hoofistuk 4 wordt nader ingegaan op modeling met audiovisuele middelen. Deze wijze van modeling makkt het mogelijk een veelheid van kenmerken van modellen en van modelgedrag, die bepalend zijn voor de 
invloed van modeling op gedrag, op gestandaardiseerde wjte op te nemen in therapieprograma's. Ervaringen met geluidsbanden a la Goldstein leerden dat deze onvoldaende respons-informatie aandragen en onvoldoende bijaragen aan de attentie van cliënten. Als om die reden worat overgegaan tot videomodeling blijkt dat aldus aangeboden audiovisuele informatie dermate complex kan zijn, dat clienten de wezenlijk geachte respons-informatie onvoldoende kunnen onderschelden van irrelevante ruis. Vandaar dat is overgegaan tot de productie van video-contrastscènes, waaxbij elke interactie tweemal wordt getoond: eenmal zonder en eenmal mèt toepassing van de vaardigheid-zoals-bedoeld onder constanthouding van irrelevante achtergrond-informatie. De inzet van eenzelfde acteur in contrast-scẽnes blijkt tenslotte noodzakelijk om bij clienten de gewenste verwachtingen van persoonlifke competentie tot gedragsverandering op te roepen. Voor elk van de 9 interpersoonlijke vaardigheden is een video-modelingprograma samengesteld met 3 contrast-scènes.

Hoofdstuk 5 biedt een beschrijving, toelichtingen op en verantwoording van het therapie-programma, zoals dat uiteindelijk vorm heeft gekregen. De vaardigheidstherapieên zijn bedoeld als aanvulling op c.q. ondersteuning van individuele (hoofd-) behandelingen.

Elk therapie-programa is gericht op het aanleren van érn interpersoonlijke vaardigheid. In vier wekelijkse groepssessies van elk twee wur, geleid door twee therapeutem, vinden in hoog tempo initerende-, anticiperende- en reconstruerende rollenspelen platts. Elk type rollenspel kent fasen van modeling, gedragsoefening en bekrachtiging. De nadruk ligt op anticiperende rollenspelen die cliëten voorbereiden op toepassingen van de betreffende vaardigheid in elgen leefsituties. De werkwijze wordt doorgelicht als toepassingsvorm van Goldstein"s structured learning therapy. Tevens wordt het therapie-programma verantwoord als middel on persoonlijke competentie-verwachtingen te verhogien, te generaliseren en te versterken.

Om op efficiënte wijze de effecten te kunnen onderzoeken van de serle van 9 interpersoonlijke vaardigheidstherapieen voor weinig-geschoolde cliënten, is de ontwkkeling van en batterij vaardigheidsmeters. 
(Skims) ter hand genomen (hoofalstuk 6).

In gesprekken met eliërten $z i$ In "onvaardigheidsuitspraken" verzameld. Deze uitspraken zijn geherfonmleera tot 3-keuze-items. De aldus tot stuand gekomen 9 'voorlopige skims' zijn afgenomen bij groepen mannen en dan factor-analyses onderworpen. Elk van de 9 analyses levende een eexste factor op, gekenmerkt doox hoge ladingen van items die de mate ultarukken waarin men zich in stat woelt, het moellijk windt, bang is on de betreffende interpersoonlijke activitelt uit te voeren. op basis daarvan zijn 9 'A-Skims' vastgesteld. In 4 van de 9 gevallen is een tweede factor gevonden die de mate betreft waxin men al dan niet tot adequate uitvoering van de interpersoonlijke activiteit woxdt gehinderd door irritatie, ongeduld of onbeheerste kwaadheid. Dit heeft tot de vaststeling van 4 "B-Skims" geleid. De interne consistenties van de 13 skims bilfken voldoende, evenals de testhertest-correlaties.

Van een tweetal A-Skims is de validitelt nadex onderzocht door groepen hoog-en laag-scoorders in 'ana loge' geênsceneerae interpersoonlijke situaties te observexen. In beide gevallen worden in een analoge live situatie hoog-scoorders doox observatoren beoorceeld als 'vaardigex' " in kwalitatief èn kwantitatief opzicht, dan laag-scoorders. Dit verschil treedt niet op bij aanbleding var video-scènes, waarbij de pxoefpersonen gevraagd worat zich te vereenzelvigen met een bepalae speler en op voorgeschreven momenten te reageren. Tijdens de videosimulatie blijkt de hartslag-frequentile van de proefpersioon hoger dan tijciens de live-simulatie.

Een en ander wordt toegeschreven aan de niet-analoge kenmerken van de video-ginulatie.

In het lateste hoofdstuk wordt de vraag maax de effectivitelt van de inmiddels in de ambulante geestelijke gezondheidszorg geimplementeerde vaardigheldstherapieên aan de orde gesteld. Gekozen wordt voor doelgebonden en doelvrije uitkomst-criteria, die deels client-specifiek zijn.

Biy deelnemers aan de lnterpersoonlijke vaardigheldstherapieën zijn, een week woor en een week na hun deelname, metingen verricht. Dezelfde gegevens $z i j n$, op vergelijkbare tijdstippen, verzameld bij mensen op 
de wachtlijst voor deelname an een vaardigheidstherapie, ale tijdens thun wachtperiode normaal. contact houden met hun hoofdbehandelaar/ verwijzer.

De vaardigheiastherapieën blijken aan hun doel te beantwoorden: verschll-scores van de experimentele groep tussen voor- en nametingen op de vaardigheldsmeters (Skims) blijken groter te zijn dan die van de wachtlijst-controle-groep terwijl ook de reductie van client-en vaardigheid-specifieke klachten bij deelnemers groter is dan bij de controle-groep. De vaardigheidstherapieen blijken eveneens tot een significante toename vam de zelfwaardering van cliënten te leiden in tegenstelling tot de individuele hoofdbehandelingen. Vergelijkingen tussen de experimentele en de controle-conaltie ten aanzien van de mate waarin deze bijdragen aan reductie van cllënt-specifleke hoofdklachten leveren geen eenduidige verschillen op.

Deelname aan meerdere therapie-programma" $s$, in de praktijk eerder regel dan uitzondering, blijkt vexantwoord: vervolg-deelnamen zijo even effectief als eerste deelnamen in het (verder) vergroten van de zelfwaardering en reduceren van client-specifieke hoofdklachten. Om de duuxzamheld van de effecten te onderzoeken is een 30-tal cliënten na een jaar opnieuw benaderd. Van 25 daarvan (838) konden gegevens worden verkregen. Uit vergelijkingen tussen de eerste en de tweede nameting blijkt dat terwijl de zelfwaardering stabirel blijft, de interpersoonlijke vaardigheden verder toenemen en cliënt-speclfleke klachten, zowel algemene hoofaklachten als vaardigheld-specifieke klachten, verder af memen. 
SUMMARY

The introductory chapter of this dissertation describes the poor relationship between contemporary psychotherapy and lower class clients. Past and current efforts made elsewhere to bridge the resulting gap are reviewed. Goldstein's structured learning therapy is presented as a method adapted to the needs and possibilities of lower income groups. The procedure is brief and directive, features modeling and relnforcement, as well as behaviour and transfer training, and alms at the acquisition of skills or the extension of behavioural patterns. When population and client records were compared, it was found that among those applying for relief to the Limburg Regional Institutions for ambulatory mental health care (so-called RIAGG"s) the lower classes were represented in a relatively large proportion. The conclusion is drawn that operationalization and implementation of Goldstein"s method within the Limburg RIAGG"s are well connendable.

The second chapter considers the developments to which the social learning theory has been subject in the past few years and the consequences of recent views to skill theraples, more particularly to the structured learning therapy. These developments and views redate mainly to the "(re-) recognition" of the role played by cogritive fiactors in explaining-models of behaviour and its modification. The dissertation deals more speciflcally with Bandura's self-efficacy theory, which assigns a nuclear position to personal expectations about one's own competence. These expectations are based on four sources of information, actually proven performance accomplishment 
being the most influential of them. It is established that the structured learning therapy, by the side of response and responseoutcome information, also furnishes data relevant to the development of expectations regarding personal competence. Reconsidered in a cognitive social learning-theoretical perspective, and on the strength, notably, of the method's performance-based character, it is concluded that Goldstein"s skill therapy still creates the best conceivable conditions for behaviour modification in the interpersonal domains.

In the third chapter it is tried to provide substance to the choice of interpersonal skills for incorporation in the therapy programmes to be operationalized. Leary's rose has been taken as a reference source for the wide range of interpersonal modes of behaviour. A list of statements supported on this model, the so-called Interpersonal Check List, is completed by a random client sample. After the tool employed in the investigations, as well as the underlying model, has been subjected to verification, the target group -i.e. clients from the lower social classes- are compared with the other clients. It appears that the former describe themselves as having a greater sense of solidarity.

Further data processing yields the inference that 'behavioural flaws' relate especially to the capability of adopting leading and competitive roles, whereas excessive behaviour is chiefly encountered in helping/ responsible and withdrawing interpersonal behaviour. From this grouplevel assessment ensues the extrapolation that the target group have a great need for interpersonal skill therapies which are designed to improve such skills as are essential in initiating and maintaining contacts, responding actively to other people, chanelling one's own and handling another person's anger, expressing opinions and feelings, and opposing others.

The fourth chaptex deals with modeling in which audiovisual tools are used. This approach makes it possible for a multitude of enhancers -which are decisive to the influence modeling has on behavlour- to be included in therapy programmes in a standardized manner. Experiences with sound tapes of the kind employed by Goldstein have 
shown that these offer insufficient resporse material, and that their contribution to the'retention of elient's attention is likewise inadecuate. When video-nodeling is applied on that ground, it appears that the audiovisual information thus presented may be of such complexity as to keep clients from sulably distinguishing essential response information from lirrelevant noise. For this reason, production of video-contrast scenes has been changed over to, with every intexaction being shown twice: once without and once with application of the enwisaged skill, while keeping irrelevant background information on a constart level.

Finally, pexfomance by the same actor in contrast scenes proves necessary to generate the desired expectations in clients with respect to competence in terms of behaviour modification. A video-modeling programme of 3 contrast scenes has been prepared for each of the 9 interpersonal skills in question.

The rifth chaptex offers a description, eluclations and a justification of the therapy programe in its ultimate design. The skill therapies are intended to complement or support individual (principal) treatments. Each therapy programme aims at the agquisition of a single interpersonal ski1.1.

Imitating, anticipatory and reconstructing role-playing takes place at a high rate during four weekly group sessions of 2 hours each, which are led by two therapists. Every type of role-playing encompasses phases for modeling, behaviour training and reintorcement. Emphasis is on anticipatory roles which prepare clients for application of the inherent skill in thelr own life situations.

The method 1 s screened as an applied form of Goldstein's structured Learning therapy" Furthermore, the therapy prograrme is justified as a tool for increasing, generalizing and relinforcing expectations of personal competence.

The sixth chapter discusses the development of a battery of skill meters. somalled skims. These have been composed to facilitate efficient investigation of the effects achieved with the series of 9 interpersonal 
skill therapies for lower class clients.

Talks were arranged with clients to collect 'statements about self-perceilwed unskilifulness", which were next reformulated into triple-choice items. The resulting batch of 9 tentative skims was filled in by groups of males and subsequently examined by factor analysis. Each of the 9 analyses yielded a primary factor with high loadings of items expressing the subjects' feelings about participation in the proposed interpersonal activity in terms of difficulty and anxiety. On tire wasis of the vutcolne, 9 "A. "Skins were composed. In 4 out of 9 cases a second factor was found, which revealed the extent to which the adequacy of a participant's performance of the interpersonal activity was hampered by irritation, impatience or uncontrolled anger.

At this point, $4{ }^{\prime} \mathrm{B}$ ' Skims were defined.

Internal consistencies proxed sufficient throughout the set of, now, 13 skims in all, as did the correlations between the first and the repeated tests. "The validity of 2 "A" skims was examined nore exhaustively, with observation of groups of high- and low-score subjects in analogue interpersonal situations set up in the laboratory. In either case observers judged the performance of the high-score groups to be superior in both quality and quantity to that of the low-score participants in a live analogue situation. This difference was not comfirmed when wideo scenes were offered and subjects were asked to identify with a certain player and to react at flxed points of time. During the video simulation heart rate appeared higher than in the live simulation. This was attributed to the non-analogue elements characterizing the video simulations.

Whe last chapter raises the effectivaness of the skill theraples meanwhile incorporated in the activities of the ambulatory mental hedth institutions. The choice 1 s for both goal-based and goal-free criteria, some of which are client-specific.

Participants of the interpersonal sk112 theraples were subjected to measurings one week before and one week after particlpation. "The same data were collected at comparable points of time with people who occurred on a waiting 1ist for particlpation in a skill therapy and 
who maintalned nomal contacts wh their principal -and referringtheraplat duxing the walting period.

The skill therapies have been found to meet their goal: differencescores for the experimental group between pre- and post-measurings by the Skims proved to exceed those of the waiting-list control group, whlle also the reduction of client- and skill-specific complaints of participants was greater than in the control group.

The skill therapies have furthex demonstrated to lead to a significant Increase in clients' self-esteen, contrary to the individual principal treatments. Comparison of experimental and control conditions for the extent to which they contribute to reduction of client-specific, principal complaints do not reveal any distinct discrepancies.

Particlpation in several therapy programmes -which is rather the rule than the exception in practice- has shown to be justifled: repetitive participations are as effective as the initial ones as far as the (continued) increase of self-esteem and reduction of client-specific principal complaints are concerned.

In order to check the lasting quality of the effects, 30 clients were reapproached after 1 year. Information could be obtained about 25 people $(\mathrm{B} 3 \mathrm{~B})$. Comparison of the first and the second remeasurings disclosed that, while self-esteem remains stable, interpersonal ski11s continue to improve and client-specific complaints - whether general, or skil1-specific- are subject to further reduction. 
LITERATUUR

Alden, L. en R. Cappe: Monassertiveness: skill deficit or selective self-evaluation. Behavior Therapy, 1981, 12, 107-114.

Andriessen, J.H.Th.: Interne of externe beheersing.

Ned. T. voor Psychologie, 1972, 27, 173-189.

Armstrong, R.G.: The Leary Interpersonal Checklist: A reliability study. J. of Clin. Psychol., 1958, 14, 393-394.

Arrindel1, W.A., P.M. de Groot en J.A. Walburg: Schaal voor interpersoonlijk gedrag. Lisse, Swets zeltinger, 1980.

Atkinson, w.W.: Motives in fantasy, action and aociety.

New York, Princeton, 1963.

Bandura, A., D. Ross, S. Ross: Imitation of film-mediated aggressive models. J. Abromal and Soatal Psychology, $1963(a), 66,3-11$.

Bandura, A., D. Ross, S. Ross: Vicarlous reinforcement and imitative learning. J. Abnomat and Social Paychology, 1963 (b), 67, 601-607. Bandura, A.: Influence of models' reinforcement contingencies on the acquisition of imitative responses. $J$. Oyersonality and Sodiat Paychology, 1965 (a), 1, 589-595.

Bandura, A. : Vicarious processes: A case of no-triál learning. In: L. Berkowitz (ed.): Advances in expemimental soctal psyahotogu, 002. II. New York, Acadenic Press, 1965 (b).

Bandura, A., F. Menlove: Factors determining vicarious extinction of avoldance behavior through symbolic modeling. of. of Personality and Soatal Psychology, 1968, 8, 2, 99-108.

Bandura, A.: Principles of behavior modification.

New York, Holt, Rinehart and Winston, 1969. 
Bandura, A., R.W. Jeffery and E. Gajdos: Generdizing change through partichant modeling with self-directed mastery. Behaliour Research and wheropy, 1975, 12, 141-152.

Bandura, A." Sodiat Learning Theory. Englewood Cliffs, M.J., Prentice Hal1, 1977.

Bandura, A.: Self-efflcacy: Toward a unifying theory of behavioral change. Psychologicat Peview, 1977, 84, 2, 191-215.

Bandura, A., N.E. Adans en J. Beyer: Cognitive processes mediating behavioral change. Journat of Personality and Social Foychology, $1977,35,3,125-139$.

Bandura, A.: Reflections on self-efficacy. In: C.M. Franks en G.T. W1son: Anmal Review af Behavior Therapy, theory and praatioe. New york, Brunner/Maze1, 1979.

Bandura, A., M.E. Adams, A.B. Hardy en G.N. Howells: Tests of the generality of self-efficacy theory. Cognitive Therapy and Research, $1980,4,2,39-66$.

Barlow, D.H., G.G. Abel, E.B. Blanchard, A.R. Bxistow en I.D. Young:

A heterosoclal skills behavior checklist for males.

Behavior Therapy, 1977, 8, 229-239.

Battle, C.C., S.D. Imber, R. Hoehn-Saric, A.R. Stone, E.R. Nash.

J.D. Frank: "Target complaints as criteria of improvement.

An. J. of Paychotherapy, 1966, 20, 184-192.

Beck, A.T.: Cognitive theropy and emotional disorders.

New York, Interr. Univ. Press, 1976.

Beekers, M. B. Beckers, J. Bongaarts en J. Peters: Psychotherapeutische hulpverlening aan cliënten uit de lagere sociaal-economische klassen: Een keuze voor Goldstein. 1. woor Poychotherapte, 1980 , $0.87-98$.

Beekexs, M. en J. Gooljen: Spel met grenzen: Een Goldsteintherapie. T. woor Paychotherapie, 1980, 6, 326-337.

Beokers, M.: Videomodelien in vaardigheidstherapieen. De Poycholoog, 1980, 11, 629-636.

Beekers, M. en R. Halfens: Met het oog op vaardigheldstherapleên:

clienten over hun interpersoonlijk gedrag.

1. woor Psychotherapie, $1981,6,318-327$. 
Bellack, A.S., M. Hersen en S.M. Turnex: Rolle playing tests for assessing social skills: Are they valid?

Behavior Therapy, $1978,9,48-461$.

Bellack, A.S., M. Hersen en D. Lamparski: Role playing tests for assessing social skills: Are they valid? Are they useful?

J. of Consulting and Clinical Psychology, 1979, 47, 335-342.

Bellack, A.S. en M. Hersen (eds.): Researoh and pratioe in sociat SkilZs prathing. New York, Plemum, 1979.

Berger, S.M.: Incidental learning through vicarious reinforment.

Psychological Reports, 1961, 9, 477-491.

Bernstein, B.: social class, speech systems and psychotherapy.

Br. J. of Sociology, 1964, 15, 54-64

Brian, M. en G.T. Wilson: Treatment of phobic disorders using cognitive and exposure methods: A self-eficacy analysis.

J. of Consulting and Clinical Psychology, 1981, 49, 6, 886-899.

Borgatta, E.F.: Analysis of social interaction: Actual, role playing and projective. J. of Abnomat and Soaial Psychozoy, 1955, 51. $394-405$.

Borgatta, E.F.: Rankings and self-assessments: Some behaviorall

characteristics replication studies. T. of Soatal Pychology, $1960,52,297-307$.

Borgatta, E.F.: The structure of personality characteristics.

Behaviorat Sczence, 1964, $9,8-17$.

Borkovec, T.D. , D.J. Fleishman en J.A. Caputo: The measurement of anxiety in an analogue social sitiation. $J$. of Consulting and Clinical Psychology, 1973, 41, 3, 157-161.

Bourque, P. en R. Ladouceur: Self-report and behavioral measures in the assessment of assertive behaviox. T. Of Behavior Theropy and Expemmentaz payohiatry, 1979, 10, 287-29:.

Bremer, J.J.C.B.: De ziekenhuispatient.

Utrecht, Dekker en V.d. Vegt, 1972.

Briar, S. en J. Bieri: A factor analytic and trait inference study of the Leary Interpersonal Checklist. \%. of CLinical Peychology, $1963,19,193-198$. 
Brinkman, W. en J. Hox: Ben ageertiviteitsschoal I.

Intern rapport, G.U. Anstexdam, 1977.

Brinkon, W.: Een aesertiviteitsachaal II.

Intern rapport, G.U. Amsterdam, 1977.

Brown, R.: Soaral Poyahozogy.

Iondon, Collier-MaMllian, 1965.

Brown, R.D., L.A. Brown en J.E. Davidson: Instructional treatments, presenter types and learner characteristics as significant variants in instructional television for adults. O. of Educational Psychology, 1975, 87, 391-404.

Burkhart, B.R., S.B. Green en W.H. Harrison: Measurement of assertive behavior: Construct and predictive validity of self-report, role-playlng and in vivo measures. T. of Clinical Psychologus $1979,35,2,376-383$.

Callner, D.A. en S.M. Ross: The reliability and validity of three measures of assertion in a drug addict population.

Behavior merapy, 1976, 7, 659-667.

Carson, R.C.: Intercetion concepts of Personality.

London, G. Allen and Unwin Lta., 1969.

Carter, L.F.: Evaluating the performance of individuals as members of smald groups. Personnel Psychology, 1954, 7, 477-484.

Clarke, J.V. en H. Arkowitz: Social anxiety and self-evaluation of interpersonal performance. Psychologiaal Reporta, 1975, 36, 211-221.

Colle, N.J., C.H. Branch en R.B. Allison: Some relationships between social class and the practice of dynamic psychotherapy. Am. T. of Psychiatm, 1962, 118, 1004-1012.

Curran, J.P.: Social skills: Methodological issues and future directions. In: A.S. Bellack en M. Hersen (eds.) : Reeearch and practice in Socital skilla Praining. New York, Plenum. 1979.

Cuvelier, F.J.: De Stad van Axen; Een topologische verkenning van de krachten tussen mensen. Kapellen, De Ned. Boekhandel, 1976.

Cuvelier, F.: Psychodrama en interaktiedrama, sociodrama en roltrainilng. 1. voor PEychotherapie, 1976, 2, 206-213. cuveliex, F.J.: Tnaginaixe en sociale intexaktie. Hove, Interaktie-Akademie, 1977. 
Dam, R. van en F. Kraaimaat: Assertieve training.

In: Hondboek woor Gedragstherapie. Deventer "Van Loghum sLaterus, $1979, B, 7$.

Dantzig, A. van: Instituut voor Multidsciplinaire Psychotheraple (IMP).

In: M.A.J. Romme (red.): Voorzieningen in de geestetijke geandheidszorg. Alphen a/d Rijn, Samson, 1978.

Decharms, R. en M.E. Rosenbaum: The problem of vicarious experiences.

In: D. Miner (ed.) : Decisions, walues and groups.

New York, Pergamon, 1960.

Decker, Th., F. van Ham en H. Vroemen: Registratiegegevers 1975,1976 en 1977 S.G.G.Z. Maastriaht e.o.

Afdelirug Administratie, niet gepubliceend, 1978.

Denholtz, M., E. Mann: An automated audiovisual treatment of phobias actinistered by non-professionals. T. of Behowior themapy ahd Expemimental Psychiatry, 1975, 6, 111-115.

Diekstra, R.F.W.: Interpersonal Checklist; Nederlandse bewerking. Niet gepubliceerd, Nijmegen, 1972.

Diekstra, R.F.W. en J.I. Truckenmiller: Cross-cultumele structurete validatie wan de Intempersonat checklist. Niet gepubliceerd, Nijmegen, 1977 .

Dohrenwend, B.P. en B.S. Dohrenwend: Social status and psychologioal disorder: A causal inquiry. New York, Wiley, 1969.

Elslex, R.M., P.M. Milier en M. Hersen: Components of assertive behavior. J. of Consulting and clinical Psychology, 1973, 29, 295-299.

Ejsler, R.M., M. Hersen, P.M. Miller en E.B. Blanchard: Sltuational determinants of assertive behavior. $J$. of Consulting and clinicat Esychotagy, $1975,43,330-340$.

Eliler, R.M.: The behavioral assessment of social skil1s. In: M.

Hersen en S.A. Bellack: Behcvioral Assesment.

New York, Pergamon Press, 1976.

Ellis, A.: Humanistische psychotherapie - de rationeel-emotieve Benadering. Deventer, Van Loghum Slaterus, 1979.

Farrell, A.D., M.J. Mariotto, A.J. Conger, J.P. Curran en J.L. Wallander: Self-ratings and judges ratings of heterosexual soctal anxiety and skill. a generalizability study. $\int$. of consulting and clinical Peychology, 1979, 1, 164-175. 
Fidlex, D. en L.R. Beach: on the decision to be assertive.

J. of Climical Paychology, 1978, 46, 537-546.

Foa, $U_{*} G_{*}$ : Convergences in the analysis of the structure of interpersonal behavlox. Pgychologiad Review, 1961, 68, 341-353.

Galasil, M.D. en J.P. Galassi: The effects of role playing variations

an the assessment of assertive behavior.

Behavior the mapy, $1976,7,343-347$.

Galass1, J.G., J.G. Hollandsworth, J.C. Radecki, M.I. Gay, M.R. Howe en

c.L. Evans: Behavioral pexformance in the validation of an assertiveness scale. Behavior Therapy, 1976, ?, 447-452.

Gambr111, E.D. en C.A. Richey: An assertion inventory for use in assessment and research. Behavior Therapy, $1975,6,550-561$.

Gambr111, E.D.: Behoviox modification: Hondbook of assessment, interw vention and evaluation. San Francisco, Jossey-Bass, 1977.

Glelss, Seldel en Abholz: Soztate Psychiatrie: Zur Ungtetonkett in der paychiatrishen Versorgung. Frankfurt a/d M, Fischer Verlag, 1973. Goldstein, A.P.: Structured learing therapy, toward a psyahotherapy for the poor. New York, Academic Press, 1973.

Goldsteln, A.P., A.W. Goedhat en H.R. Wijngaarden: Modelling in de psychotherapie bij patienter uit de lagexe sociale klasse. In: Cassee, Boeke en Barendregt: KLinische Payohologie in Neder Zand, dee2 2. Deventer, Van Loghum Slaterus, 1973.

Goldstein, A.P., R.P. Sprafkin en W.J. Gershaw: SkizZ training for commuthy living: applying structured leaming therapy. New York, Pergamon Press, 1976.

Goldsteln, A.P., F. F. Kanfer (eds.): Maximizing treatment gains, trangfer enhancenent in psychotherapy. New York, Academic Press. 1979.

Goldstein, A.P., R.P. Sprafkin, N.J. Gershaw en P. Klein: SkiZlstreaning the adolesoent. Champalgn, Illinois, Research Press, 1980.

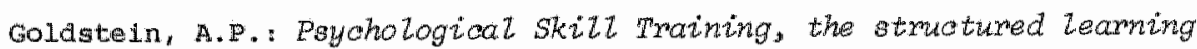
therapy. New York, Pergamon Press, 1981.

Goreck1, P.R., A.I. Dickson, H.N. Anderson en G.E. Jones: Relationship between contrived in vivo and role-playing assertive behavior. J. of clinical Psychology, 1981, 37, 104-107. 
Gould, R.E.: Dr. Strangeclass: or how I stopped worrying about the theory and began treating the blue-collar worker. Am. of. of Orithopsychtatry, $1967,37,78-86$.

Green, A., G. Marlatt: Effects of instructions and modeling upon affective and descriptive verbalization.

J. of Abnormal Dsychology, 1972, 80, 189-196.

Groenman, N.H.: ZeZfbeeZd en borstbeeZd.

Groningen, dissextatie R.U., 1978.

Halford, K. en M. FoddY: Cognitive and social skills correlates of social anxiety. Br. J. of Cinical Psychology, 1982, 21, $17-28$.

Hasselt, V.B. van, M. Hersen en A.S. Bellack: The validity of rolle play tests for assessing social skills in chilaren.

Behavior Therapy, 1981, 12, 202-216.

Heimberg, R.G., D. Montgomery, C.H. Madsen Jx, en J.S. Helmberg: Assertion training: A review of the literature. Behavion Therapy, 1977, 8, 953-971.

Heimberg, R.G., D.F. Harrison, I.S. Goldberg, S. DesMarais en S. B.Ieu: The relationship of self-report and behavioral assertion in an offendex population. I. of Behavion Thernoy and Experimentat Psychiatry, $1979,10,283-286$.

Hettema, P.J.: Ontwikkelingen in de interactionistische persoonljjkheidspsychologie. De Paycholoog, 1982, 17, 4, 157-166.

Higgins, R.I., R.R. Alonso en M.G. Pendleton: The validity of role-play assessments of assertiveness. Behavior Therapy, 1979, 10, 655-662. Hodges, W.F. en C.D. Spielberger: The effects of threat of shock on heart rate for subjects who differ in manlfest anxiety and fear of shock. Psychofysiology, 1966, 2,4, 287-295.

Hollingshead, A.B. en F.C. Redlich: Social alass and mental itiness. New York, Wliey, 1958.

Johnson, $\mathbb{L} . C$. en A. Lublin: on planning psychophysiological expeximents. In: Greenfield, N.S. en R.A. Sternbach: Hanabook of Paychophysiozogy. New York, Holt, Rinehart and winston, 1972.

Jones, E.: Social class and psychotherapy: A critical review of research. Psychiatry, 1974, 37, 307-320. 
Wanfer, F.H. " Taroly en A. Newan: Source of feedback, observational learning and attitude change. T. of Personality and social Paycholagy, 1974, 29, 30-38.

Kazdin, A.E.: The effects of model ldentity and fear-relevant similarity on covert modeling. Behawion therapy, $1974,5,624-635$.

Kazdin, A.E.: Covert modeling, model similarity and reduction of avoidance behavior. Behovior Therapy, 1974, 5, 325-340.

Kesler, I.D.: Use of individualized measures in paychotherapy and mental program evaluation regearoh. A review of target complaints, probtem omiented record and goal attairment scaling.

Virglnia common Wealth university, 1977.

Knippenberg, F" van: Exploratief onderzoek naca he interpersoonlijk gedrag van thute tosen.

Nifmegen, doctoraalscriptie, 1978.

Konn, M.I. : Class and conformtity, a sudy in valises.

Homewood, Jlilinois, Dorsey Press, 1969.

Kouwer, B.J." Een bewerking van de contrastprofielen-methode van

osgood. Ned. 1. 2. d. Psychologie, $1958,13,1-4$.

Kouwer, B.J.: Onaangename situaties.

Ned. T. v.d. Psychologie, 1961, 16, 117-125.

Kreitler, H. en S. Kreitler: Validation of psychodramatic behaviour against behavioux in real life. Br. $T$. of Medical Psychology, $1968,41,185-192$.

krumboltz, J., N. Thoresen (eds.) : Behowioral counseling: Cases and techriques. New York, Holt, Rinehart and winston, 1969

Laforge, R. en R.F. Suczek: The international dimension of personality"

III: An Interpersonal Checklist.

J. of peroonality, $1955,24,34-55$.

Lang, P.J.: The application of psychophysiological methods to the study of psychotherapy and behavior modification. In: Bergin, A.E. en S.L. Garfiela: Handbook of psyohotherapy and Behavion Change. New York, Wiley, 1971.

Lazarus, A.: Behavioral rehearsal versus non-directive therapy versus advice in effecting behavior change. Behavion Researoh and Theropy, 1966, 4, 209-212. 
Leary, T. : Interpensonal Dirghoeds of Personality.

New York, Ronald Press Company, 1957.

Iilberman, R.P.: Persoonlitike effectivitett.

Amsterdam, Bakker, 1977.

Jick, J.R. en E.S. Katkin: Assessment of Anxiety and Fear.

In: Hersen, M. en A.S. Bellack: BehavioraZ Assessment, a pratiad

Hordibook. New York, Pergamon Press, 1976.

Liplnsky, D. en R. Nelson: Problems in the use of naturalistic observation

of depressed persons. T. of Coms. and Ctintic. Paychology, 1974a, $40,304-312$.

Lipinsky, D. en R. Nielson: Problems in the use of naturalistlc observation as a means of behavioral assessment. Behovion Therapu, 1974b, 5 , $341-351$.

Lorion, R.P.: Research on psychotherapy and behavior change ith the disadvantaged. In: Garfield, S.I. en A.E. Bergin (eds.): Handbook of psychatherapy and behavion change, second edition.

New York, Wlley, 1978.

Lorr, M. en D.M. MCNair: An interpersonal behavior circle.

7. of Abnomal soc. Paychol., 1963, 67, 68-75.

Lundberg, M.J.: The incomplete adult.

Westport, Conn., Greenwood Press, 1974.

Lykken, D.T., R. Rose, B. Luther en M. Maley: Correcting psychophystological measures for individual differences in range. Psychological Bultetin, 1966, 66, 6, 481-484.

Marlatt, G.: Task structure and the experimental modification of verball behavior. Psyahotogicaz Bulzetin, 1972, 78, 335-350.

Marzillier, J.S., C. Lambert en J. Kellett: A controlled evaluation of systematic desenstisation and social skills training for socially inadequate psychiatric patients. Behopior Researeh and Theroou, $1976,14,225-238$.

McFal1, R.M. en A.R. Maxston: An experimental investigation of behaviox rehearsal in assertive training. J. of Abnormal Payohology, 1970 , $70,2,295-303$.

MCEall, R.M.: Analogue methods in behavioral assessment: Issues and prospects. In: J.D. Cone en R.P. Hawkins (eds.): Behavioral Assessment. New York, Bruner/Mazel, 1977. 
MeLchenbaun, D.H." Cognit tive-Behaviar Modifiadion.

Wev York, Plenum Press, 1977.

Mel110, J. en A. Goedhart: Soclodrama, en soclale therapie. Mocandblad Geestelïke Volksgezondheid, 1980, 35, 15-31. Meltzoff, J. en M. Kornrelch: Research in psychotherapy.

New York, Atherton Press, 1970.

M1lex, S.M. en $\mathbb{F}$. Riesgman: The working class subculture: A new view.

In: A.L. Grey (ed.): Class and personality in society.

New York, Atherton Exess, 1969.

Mischel, W.: Toward a cognitive social learning reconceptualization

of personality. Peychological Review, 1973, 80, 4, 258-283.

Nemetz, G., K. Cralg, G. Relth: Treatment of female sexual dysfunctions

through symbolic modeling. J. of Consulting and Clinicat Psychology, $1978,46, \quad 1,62-73$.

Nietzel, M.T. en D.A. Bernstein* Effects of instructionaliy mediated

demand on the behavioral assessment of assertiveness.

J. of Conoulting and Clinical Psychology, 1976, 44, 500.

Nijhof, G.: Sociale ongelijkheid en psychische stomingen.

Nijmegen, Lilnk, 1979.

O'Banien, $k$. en H. Axkowitz: Social anxiety and selective memory for

affective information about the self. T. of Consulting and

Clinical Pgychotogy, 1977, 45, 217-218.

O'Connor, R.: Modification of social withdrawal through symbolic

modeling. $J$ of Applied Behavior Analysis, 1969, 2, 15-22.

O"Dell, S.L., J.A. O'Quin, B.A. Alford, A.L. O"Briant, A.S. Bradlyn

en J.E. Giebenhain: Predicting the acquisition of parenting skills via

four training methods. Behavior therapy, 1982, 13, 194-208.

orme1, H.: Moelte met leven of een moeliljk leven.

Intexmediain, 1981, $17,35,57-63$.

Osgood, C.E., G.J. Suci en T.H. Tannenbaum: The medahrement of meaning.

Uxbana, IIInois, Undv, of IIILnois, 1957.

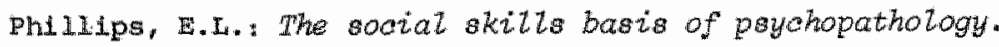

New York, Grune and stratton, 1978.

Pljpe, G.: Psychotheraple met de patient van laag ontwikkelingsniveau.

1.v. Paychotherapie, 1976, 2, 71-80. 
Rapaport, I.: The state of crisis: Some theoretical considerations:

Social Serviae Revtew, 1962, 36, 211-217.

Rathus, S.A.: A 30-item schedule for assessing assertive behavior.

Behavior Therapy, 1973, 4, 398-406.

Riessman, $F^{*}$ en S. Scribmer: The underutilization of mental health

services by workers and low-income groups: causes and cures.

Am. J. of Psychiatry, 1965, 121, 798-801.

Riksen, B.: Subassertiviteit en kognitie, een assertieve training op

basisi van Bandura's sociale-leertheorie.

Gedrag, T.2. Psychologie, 1831, 9, 1, 38-55.

Rosenberg, M.: Sootety and the adolescent self-tmage.

Princeton, Princeton University Press, 1965.

Rosenthal, T., A. Bandura: Psychological modeling: Theory and practice.

In: Garfield, S. en A. Bergin (eds.): Hamdbook of psyohotherapy

and behaviom change. New York, Joln Wiley and Sons, 1978.

Rotter, J.B.: Generalized expectances for internal versus external

control of reinforcement. Psych. Monographs, 1966, 80, 1-28.

Rubin, L.B.: Worlds of pain.

New York, Basic Books, 1976.

Samenlevingsopbouw Zuidelijk Limburg: VersLag wan een ondergoek náar het vornings-en ontwikkelingswerk voor volwassenen in de regio Zuidelijik Limburg. Niet gepubliceerd, 1978.

Sanders, G.J.E.M.: Het gewone en het bijzondere van de homosekauele

Leefsituatie. Deventer, Van Loghum Slaterus, 1977.

Schaefer, E.S.: A circumplex model for maternal behavior.

J. of Abnorm. Soc. Psychol., 1959, 39, 226-235.

Schagen, S.: Meten met matige maten: over ultkonstcriteria bly het

onderzoek naar psychotherapie. Wed. T. Poychologie, 1979, 34, $6,5-85$.

Schmidt, W., R.G. Snart en M.K. Moss: Social alasi and the treatment of alcoholism. Toronto, Univ. of Toronto Press, 1968.

schofield, w.: Psychotherapy, the purchase of friendship.

Englewood Cliffs, Prentice Hal1, 1964.

schouten, $\pi_{.}$: Ik ber d'p' ook nog.

Amsterdam, Boom, 1977. 
Schutz, W.C.: The interpereonal underworld.

Palo Alto, Science and Behavior Books, 1966.

Schutz, H.: Gedragstheraple biy IMP-cliernten -een statistisch demograflsch onderzoek. De Pagcholoog, 1981, 16, 10, 690-701.

Schwartz, R.M. en J.M. Gottman: Toward a task analysis of assertive behavior. J. of Consulting and Clintad Psychotogy, 1976, 44, $910-920$.

Scott, J.D. en J.G. Phelan: Expectations of unemployable males regarding source of control of reinforcement. Psychological Reports, 1969, 25, 911-913.

Shaplro, M.B.: A method of measuring psychological changes specific to the individual psychiatxic patient..

Bir. J. of Medicat Psychotagy, 1961, 34, 151-155.

Skillings, R.E., M. Hersen, A.S. Bellack, M.P. Becker: Relationship of speciftc and global measures of assertion in college females. J. of Clinioal Pezahology, 2978, 34, 346-353.

Sloane, R.B., F.R. Staples, A.F. Cristol, N.J. Yorkston en K. Whipple: Psychathenapy vergus behavion therapy.

Cambridge, Harvard Univ. Press, 1975.

Smith, R.E. en G. Sarason: Social anxiety and the evaluation of negative interpersonal feedback. ef. of Consulting and ctinical Psychotogy, 1975, 43, 429.

Son, M.J.M. wan: Soctaze vaardigheidstherapte, gedragetherapie en sociact gedrag. Amsterdam, Swets Zeitlinger, 1978.

Son, M.J.M. van: Ontwlkkelingen binnen de sociale vaardigheidstherapieen. Bulzetin van de Vereniging voor Gedragstherapie, 1980 , $13,3,3-24$.

Splegler, M., R. Liebert, M. McMains, L. Fernandez: Experimental development of a modeling treatment to extinguish persistent avoldance behavior. In: R. Rubin en C. Franks (eds.): Advances in behavion therapy 1968. New York, Acadenic Press, 1969. spielberger, C.D.: Arxiety; cument trends in theory and research. New York, Academic Press, 1972.

Stanton, H.R. en E. Hitwak: Toward the development of a short-form test of interpersonal competence. American sociological Review, $1955,80,608-674$. 
Steffen, J.J. en J. Redden: Assessment of soclal competence in an evaluation-interaction analogue.

Thmon Conmumication Research, 1977, 4, 1, 30-37.

Strupp, H.H.: Psychotherapy Research and Practice: An overview.

In: S.L. Garfield en A.E. Bexgin (eds.): Hardbook of psyohotherapy and behrotor change, second edtition. New York, wiley, 1978.

Stufkens, T.: Een introduktiekuras woor Psyohothempie.

Utrecht, dissertatie R.U., 1977.

Stuurgroep Maatschappelijke Spreiding Psychotherapie: Verstag van de Sturgroep Matschappeijike Spreiding Psychotherapie - (Liboprojekt). Niet gepubliceerd, 1976.

Stuurgroep Matschappelijke spreiding Psychotheraple: Libo-projekt 1977 - Jaamerstag van de Landelijke stumgroep en platiselijke coördinatoren Matsohoppetijke spreiding Psychothenopie.

Niet gepubliceerd, 1978.

sullivan, H.S.: The interpensonal theory of psyohiatmy. New York, Horton, 1953.

Theunissen, I.: Sanenvatting literatur psychofysiatogische aspecten van emoties, m.n. angst en hartstag. Maastricht, intern rapport Goldsteimproject, 1980 .

Trower, P., B. Bryant en M. Argyle: Social skilis and mental health. London, Methuen, 1978.

Truckenmilier, J.L.: Equivalence of peraonality struature in Leary's Interpersonal System of diagnosis. Diss. virginia University. 1971 .

Turck. B. de: Politiserende huzperiening, een oxientering. Nijmegen, Link, 1978.

Twentyman, C.T. en R.M. MCFall: Behavior txalning of social skills in shy males. J. of Consulting and clinical Psyohology, 1975, 43. $3,384-395$.

Twentyman, C.T. en R.T. Zimmering: Behavioral training of social gkillis: A critical review. In: M. Hersen, R.M. Elsler en P.M. Miller (eds.): Progress in behavior modification, vol. 7 . New York, Academic Press, 1979. 
Velden, $K$. van dex en $T$. Vreeken: Recht op hulp: Twee notities over de opzet van een matschappelijk relevant RIAGG in Rotterdam. Moandb Lad voor Geestelijke Volkagezondhetid, 1977, 32, 760-772. velden, K. van der (red.): Ditrektieve therapieen. Deventer , Van Loghum Slaterus, 1977.

Wallburg, J.A.: Alcoholisme en social gedrag. I. Alo. Dmge, 1980, 6, 2, 52-60.

walk, R.D.: Self ratings of fear in a fear-invoking situation. T. Of Abnormal and Soctal Psychology, 1956, 22, 171-179. Waskov, I.E. en M.E. Parlofe (eds.): Psychotheropy change measures Washington, NIMH, 1975.

Wessberg, H.W., M.J. Mariotto, A.J. Conger, A.D. Faxrell en J.C. Conger: Ecological validity of role plays for assessing heterosocial

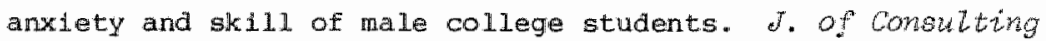
and Climioal Paychology, 1979, 47, 3, 525-535.

Westerlaak, J., J. Kropman en J. Collaris: Beroepenktapper. Nijmegen, I.T.S., 1975.

Whalen, C.: Effects of a model and instruction on group verbal. behaviors. I. of Consulting and cliniaal Psychology, 1969, 33, $509-522$.

wijngaarden, H.R.: Nog enige beschowingen over de confliotuotogie. Openbar afscheidscollege, V.U., 1978.

Willems, L.F.M., H.A. Tuender-de Haan en P.B. Defares: Een schaal on sociale angst te meten. Ned. I.v.d. Psychologie, 1973, 28, $415-422$.

Williams, C.L. en A.R. Ciminero: Development and validation of a heterosoclal skills inventory: The survey of heterosexwal interactions for females. J. of Conoutting and cinteal Poyahology, 1978, 46, B, $1547-1548$.

Wolpe, i.: Psychotheropy by reciproaal inhibition.

Stanford, Stantord Univ. Press, 1958.

wolpe, Ji en A.A. Lazarus: Behavior Themapy Techntaies.

New York, Pergamon press, 1966.

Wolpe, J.: The pratice of behavtor therapy.

New York, Pergamon Press, 1973

Yussen, S.R.: Determinants of visual attention and recall in observational learning by preschoolers and second graders. Developmental Psychology, 2974, 10, 93-100. 
BIJLAGE 1 : VERWIJZEN NAAR GOLDSTEINTHERAPIEEN

Hieronder volgen enige opmerkingen betreffende verwijzingen nax Goldsteintherapieen. Zoals $u$ weet, zijn deze kortaurende vaaraigheidstherapieën bedoeld voot cliënten uit lagere sociaal-economische klassen.

A. Verwiljzen naar een vaardigheldstherapie heeft 2 in als een van de vier volgende uitspraken van kracht is:

1. het niet-uitgerust zijn met de betreffende vaardighedd is te beschouwen als het centrale probleem van de client, of als aen onderdeel van dat centrale probleern.

voorbeeld: een client melat zich met lof kont na samenspraak met zijn hulpverlener tot de conclusie dat) 'ik kan niet voor mezelf opkomen, ik laat maar over me heen lopen'.

Verwijzen naax 'opkormen voor je mening'.

Voorbeeld: en client blijkt met alles en iedereen ruzie te hebben (thuis, op het werk, etc.). In samensprabk met zijn hulpverlener komt hij tot het besef dat hij doox zijn wijze van ongaan met conflicten laldoor weglopen, of destructief worden) deze situatles melf verooxzaakt en/of in stand houdt.

Verwityen nar: "uiten van kwaadheid" en/of " reageren op kwaalheid"

2. client"s centrale probleem wordt (mede) in stand gehouden door bepaalde vaardigheidstekorten. 
Voorbeld: client 1 verslafa aan alconol en wi daar vanaf. Eerdere pogingen daartoe mislukten. Terwgval blijkt vooral op te treden op momenten dat hij wich niet opgewassen voelt tegen ontmoetingen/gesprekssituaties waarin zaken uit- en bijgepraat moeten worden. Vexwljen naar "iets bepraten".

Woorbeyd: client durft nergens alleen nar toe. Dit probleem wordt mede in stand gehouden door de angst Lemand te ontmoeter, aangesproken te worden, en zich dan niet te kunnen handhaven. verwijzen naar "praatje maken" of "luisteren".

3. Uitwoering van een behandelingsplan wordt bemoeilijkt doordat client eer bepaalde vaaxdigheid ontbeert. Voorbeeld: behandelingsplan is erop gericht client wit zijn isolement te halen, hern sociaal actiever te laten worden. Dan blijkt dat cliënt niet in staat is contacten te leggen, mensen aan te spreken, etc. Verwijzen naar "een praatje maken'.

Voorbeelu: een hulpverlener is bezig met een echtpaartherapie, en wil op zeker moment de huiswerk-opdracht meegeven: elke dag één 'positieve boodschap' naar elkaar. Blijkt dat de man (Los van de relatieproblematiek) niet tot dergelijke boodschappen in staat is. Verwijzen naax 'uiten van genegenheid en waardering'.

4. Terwill cliênt's centrale probleem nagenoeg "opgelost" is, voorzilet de hulpverlener dat cllènt weer in nieuwe problemen zall geraken ondat hif een bepaalde vaardigheid mist.

Voorbeeld: een gezinstherapie heeft geleld tot een nieuwe meer bevredigende everwichtssituatie, acute problemen/conflicten zijn 'opgelost'. 'Tegelijkextijd is welhast voorspelbaax dat nieuwe problemen zullen ontstaan als een bepaald gezinslid in de toekomst niet mér aanspreekbaar en ontvankelijk voor (mededelingen van) gezinsleden zal zijn. Hij/zij is daartoe echter 
nawhelijks in stat.

Verwijzen naar "Histeren".

Voorbeeld: cliënt is geen man van overleg. Een stille tobberbij

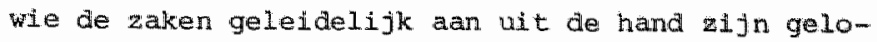
pen in zifn werkituatie. Advies, bemiddeling en inzichtgevende gesprekken hebben extoe bijgedragen, de werksituatie van de man weer recht te trekken. Het is echter te voorzien dat nieuwe problemen zullen ontstaan als de man niet voortaan tijdig wo op adekwate wijze allerlei zaken bespreekbaar makt/doorpraat met zijn chef en/of collega"s. Verwijzen naar 'lets bepraten'.

Verwijzen naar een vaardigheidstheraple heeft dus $z$ in als het verwerven van de vaardigheid bijdraagt tot een anders (kunnen) functioneren. Daarmee is de relevantie van de verwijining besproken.

B. Naast de relevantie is het wellicht nuttig de aard van de onvaardigheid nader te benoemen. In bovenstaande (A) was er regelmatig sprake van "cliënt is niet in staat tot". Dit nilet-in-staat-zijn kan zlich op verschillende wijzen mandfesteren, respektievelijk kan door diverse faktoren 'gedragen' worden:

1. Een ontoerelkend gedragsrepertaire. Cliënt heeft noolt geleerd bepaalde vaardigheden te ontwikkelen, of het eerder geleerde is in onbruik geraakt. Hij weet niet (meer) hoe een bepaalde interpersoonlijke responsklasse gestalte te geven.

2. Angst. Cliërt weat wel "hoe zolets moet", maar durft niet. Hiy voorziet awersieve gevolgen (uitgelachen worden, genegeerd worden, afgewezen of aangevallen te wordeny en vermijdt het interpersoonlijk gedrag te stelien.

3. Cognitieve standaarden. Client is behept met een aantal cogntties, opvatetingen, meningen over zichzelf als individu (1k heb toch nergens verstand vanl, over de groep waartoe hij/zij behooxt (vrouwen moeten zich op de achtergrond houder, naar gewone mensen zoals wij wordt toch niet gelulsterd), of over omgang tussen mensen (kwaadheid hoox je niet te witen) die ult- 
voering van de interpersoonlijke activiteit 'wexbieden" of beLemmerer.

4. Het komt woor dat er nöch sprake is wan een gedragstekort, nöch van angst, nòch van blokkerende cognities terwj1 toch de interpersoonlijke activiteit achterwege blijft. Het gewoonte-gedrag laltifa in de contramine, altija aardig voor iedereen, altijd hantfe de voorste) laat weinig ruimte voor de betrefferde intexpersoonlijke activiteit.

Doorgaans zal men te maken hebben met meng-vormen van de hier genoemde "typen onvadragheid". Besef van gedragstekorten roept immers vaak angst op, cognitileve standaarden leiden tot bepaalde gewoonten, etc.

De gemakte onderscheiding dient ex dan ook vooral toe verwijzers ale twijfelen aan de zin wan een verwijzing op grond van een specifleke probleeminterpretatie (bjjvoorbeeld mijn cllënt kân het best max doet het noolti) duidelijk te maken dat de vaaxdigheidsthexapie berekend is op dit type accent-verschillen.

C. Naast de releventie (A) en de aard (B) van het vaardigheidstekort, kumen hiex anige voomwarden m.b.t. de gang van zaken bij verwijzüngen niet ongenoemd blijwen.

1. Het is niet voldoende dat een verwijzende hulpverlener overtuigd is van de zin van deelname van zijn cliënt aan een bepaalde vaardigheidstherapie. Ook de cliënt dient daarvan overtuigd te zijn. Als de hulpverlener de mogelijkheld wan verwijzing naar een vaardigheidstheraple ter sprake brengt op het juiste moment. zal de client de zin van de suggestie inzien. Is de hulpverlener wat vroeg met zijn verwijsvoorstel (een aantal inzichten, aanwezig bij de hulpwerlener, zijn nog niet met de cliënt besprow ken), dan kan de cliënt reageren met verbazing en/of onbegrip. Het proces-van-overtuigen mag echter niet het kaxakter krijgen vam 'de cliënt een probleem aanpraten' of "de cliënt extan overtuigen dat hij lets niet, nawwelijks of slecht kan". De beinvloeding dient meer het karakter te dragen van: doen beseffen hoe nuttig het zal zijn als client 'handiger, makkelijker leert te....". 
2. De verwijzing dient steeds gericht te zijn op een of erkele met name genoemde vardigheden.

Men verwijst niet naar "Libo-" of 'Goldsteingroepen", maax naar specifieke vardigheden. Als de verwijzex meardere varaigheden geindiceerd acht, verdient het voorkeur de client eerst te verwijzen naar die vaardigheid die client het liefst wil verwerven. cok al komt dat niet owereen met ideeër over een mogelijke vaardigheidshiërarchie (makkelijkex en moeilijker skilds).

3. De verwijzende hulpverlener is en bijjt de hoofdbehandelaax van de cliënt. De verwijzing naar een vararigheidstherapie is een tijaelijke. De hoofdbehandelaar kan zijn contacten met de client tijdens diens deelname aan de Goldsteingxoep continueren of opschorten (naar eigen inzicht), doch dient de cliênt na afloop van de vardigheidstherapie terug te $z$ ien.

4. Cliênt's deelname aan de vaardigheidstherapie werpt de meeste vruchten af als de verwijzende hoofabehandelaar direct werk makt van de door zijn cliënt verworven vaardigheid. Hij is een belangrijke spil m.b.t. de generalisatie en duxzaameid van de gedragsverandering. Door voortgezette toepassing van het geleerde gedrag te stimuleren en te bekrachtigen draagt hij hiertoe in sterke mate bij.

5. Deelnane van client aan een serie vaardigheldstherapieen in een vxijwel ononderbroken tijdsperiode is ongewenst. Vaardigheden gaan dan elkaar overstemen, worden met elkaar verward, kxijgen niet de kans een duurzame plaats te verwerven in cliënt"s gewoonte-repertoire.

De uitwoexders van de coldsteinthexapiecn weten dat en houden ex rekening mee bij hun planning van groepen en toewijzing wan cliënten aan groepen. Hun werk worat eenvoudigex als ook verwijzers hilermee rekening houden. 
DE EERSTE ZITWTING

$0.00-0.15$

Kennismaking en introductie

- over doel en duux van de therapie

- namen uitwiselen met, naar keuze kort aangeven "walrom je aan deze groep medoet".

$0.15-0.45$

Video-modeling

- intxoducile doox autoritelt * eerste 'foute' woorbeella

- (videopauze): 'wat deed deze persoon fout"

- videa: autoriteit introduceert leerpunten, gevolgd door eerste 'goede" vooxbeeld

- (video-stop) 'wat deed deze persoon nu goed". nawragen Leerpunten $0.45-1.50$

Imiterend rollenspel

- inrichten speelvlak

- aanwijzen en instrueren antagonisten

- zonodig live modeling door co-thexapeut, of tweede maal tonen videowoorbeeld

- alienten beurtelings protagonist

- naar keuze rol. beperken tot eerste deel.

- kort instrueren

- bekrachtigen gewenst gearag

- zonodig shaping

- therapeuten wiselen elkarax af

- naar kauze ook m.b.v. tweede video-contrast-scène

$4.50-2.00$

Huiswerk - voorbespreking

- intxoduceren huiswerkbeginsel

- introduceren hulswerkboekje

- opgave eerste huiswerk "observeren" (hoe doen anderen het)

'eerste. leerpunten' (naar inzicht therapeuten) 
$0.00-0.15$

Buiswerk bespreking

per client

- bekrachtigen huiswerk - inspanningen

- OP flap noteren ev. fal-ervaringen.

$0.15-0.30$ (indien nodig)

Reconstruexend rollenspel

Op geleide van huiswerk - ervaringen

- mèt betr. client optuigen speelvlak, instrueren antagonisten, voorspel

- een - of meerdexe modelien (cotherapeut of mede-client) protagonist op "tribune"

- gedragsoefening (herkansing) protagonist, zonodig shaping + bekrachtiging

$0.30-1.00(0) 0.15-0.45)$

Imiterend Rollenspel

- m.b.v. $2 e$ of 3e video-voorbeela

- alle cliënten een beurt.

$1.00-1.50(0) 0.45-1.50)$

Anticiperend Rollenspel.

- zoveel mogelijk clienten een beurt

- n.a.v. voornemens konende week

- met live - modeling

- gedrag herieiden naar leexpunten

- zonodig shapung toepassen

1. $.50-2.00$

Hulswerkbespreking

- noteren op flap - over

- minimaal één opdracht per client

- tips aanreiken 
DE DERDE ZITITIS

$0.00-0.15$

Hul swe k bespreking

per client

- ev. Eallervaringen ook op fllap-over

- bekrachtigen!

$0.15-1.55$

(zonodig eerst reconstruerend rollenspel, maar m.n. toewerken naar) Anticlperend Rollenspel

- alle clienten een beurt

- steeds met live-modeling

- gedrag herlelden naax leerpunten

- direkt na rollenspel: hulswerk noteren zonodig net 'tips'

$1.55-2.00$

Hulswerkopdrachten

- herhaling opdrachten

- benadrukken en noteren

- minimaal Eër opdracht per client

- tips 
DE VIERDE (LAATSTE) ZITTING *

$0.00-0.15$

\section{Huiswerkbespreking}

- per client

- ev. faal-ervaringen op flap-ovex

$0.15-1.45$

(zonodig op geleide van huiswerkervaringen reconstruerend rollenspel. maar m.n.:)

Anticiperend rollenspel

- alle cliënten minimaal én beurt

$1.45-2.00$

\section{Huiswerk - ejndbespreking}

- per cliënt, voor meerdere weken

- Individuele tips

- zell-bekrachtiging stimuleren

- ev." noemen van mogelijkheld andere vaardigheden

- onderlinge afspraken tussen clienten stimuleren

* zijn er meer dan 4 zittingen, dan geldt deze beschrijving voox de laatste zitting. Voor de tussen-liggende zittingen geldt dan de beschrijving van zitting 3 . 


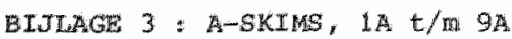

SKIM 1A : EEN PRAATJE MYMEN

1. Beginnen met een praatje

2. Een praatje maken met iemana van het andere geglacht

3. Onbekenden aanspreken

4. Contacten leggen

5. Als ik mensen zomaar aanspreek

6. Na het begin van een praatje

7. Ik wret
0 durf ik nooit 0

0 durf ik valk niet 1

o durf ik bijne altijä 2

0 wind ik antzettend moeilijk 0

o wind ik toch wel moeilijk 1

o wind ik niet zo moellijk 2

o durf ik best 2

o durf ik niet zo goed 1

0 durf ik helemal niet 0

0 kan ik maar heel moeilijk $\quad 0$

0 kan $1 k$ niet zo gemakkelijk 1

o kan ik heel genakkelijk 2

o ben lk exg bang dat ze ex 0 nlet op in gaan

0 ben $i k$ een beetje bang dat 1 ze ex niet op in gaan

0 ben ik helemal niet bang 2 dat ze er niet op in gaan

0 weet $1 \mathrm{k}$ nooit hoe ik emmee 0 door moet gaar.

0 weet ik soms niet hoe ik er- 1 mee door moet gaan

0 weet ik meestal wel hoe ik 2 exmee door moet gaan

a bijna nooit warrover ik moet 0 praten

a vaak niet waarover ik moet 1 prater

0 meestal wel warrower ik zou 2 kunner praten 
1. Als iemand me wat vertelt

2. Als iemand me wat vertelt

3. Ik weet

4. Ik durf

5. Iemand aan blijjwen kijken onder het praten

6. Ik vind

7. Als iemand me aankijkt onder het praten
0 weet ik meestal wel of ik 2 daarop door mag vragen

0 weet $i k$ vaker niet of ik 1 daarop door mag vragen

0 weet ik meestal niet of ik 0 daarop door mag vxagen

0 dringt het meestal niet tot 0 me door wat hij bedoelt

0 dringt het soms niet tot me i door wat hif bedoelt

o dxingt het meestal wel tot 2 me door wat hij bedoelt

0 altijd wel iets terug te 2 zeggen

O soms niet wat ik terug moet 1 zeggen

0 bijna nooit lets terug te 0 zeggen

O heel goed voor mijn mening 2 uit te komen

o minder goed voor mijn me- 1 ning uit te komen

o helemal niet goed voor mijn 0 mening uit te komen

0 vind ik erg moeilijk o

o vind ik niet zo genakkelijk 1

0 vind ik helemaal niet moei- 2 lijk

O bijna nooit de gelegenheld o on mijnelgen mening te zeggren

0 vaak geen gelegenheid on 1 mijn elgen mening te zeggen

0 meestal wel de gelegenheid 2 om mijn eigen mening te weggen

0 word ik daar erg onzeker van 0

0 word ik daar een beetje 1 onzekex yan

0 word ik daar helemal niet 2 onzekex $\operatorname{van}$ 
1. Een gesprek beginnen

2. Een gresprek voeren

3. Ik ben

4. Ik ben

5. Ik weet

6. Ik ben
0 vind ik moelijjk 0

0 vind $i k$ een beetje moeilijk 1

0 vind $i k$ niet zo moellijk 2

0 maakt me nexveus 0

0 maakt me een beetje nerveus 1

0 maakt me niet nerveus 2

0 meestal bang dat ze niet 0 naar me luisteren

0 vaak bang dat ze niet naar 1 me luisteren

0 vrljwel nooit bang dat ze 2 niet naar me luisteren

o vaak bang dat ze me o uitlachen

0 soms bang dat ze me 1 uitlachen

o bijna noolt bang dat ze me 2 uitlachen

o vaak niet wat ik kan zeggen 0

0 soms niet wat $1 \mathrm{k}$ kan zeggen 1

0 meestal wel wat $1 \mathrm{k} k$ an zeg- 2 gen

o vaak bang niet goed begre- 0 pen te worden

0 soms bang niet goed begre- I pen te worden

0 zelden bang niet goed be- 2 grepen te worden 
1. Wanneer liemand kwaad op mij is

2. Wanneer iemand kwaad op mij is

3. Wanneer iemand kwad op mij is

4. Wanneer ienand kwaad op mij is

5. Als iemana kwaad op $\mathrm{mil}$ is

6. Mensen die kwaad op me zijn
0 weet ik meestal wel hoe ik 2 darop kan reageren

a weet ik soms niet hoe ik 1 daarop kan reageren

0 weet ik meestal niet hoe ik 0 daarop kan reageren

0 voel ik me exg vernederd 0

a voel ik me wel wat vernederd 1

0 voel ik me vrijwel niet ver- 2 nederd

0 maakt me dat erg bang 0

O makkt me dat wel een beetje 1 bang

a maakt me dat niet bang 2

0 maakt me dat erg nerveus 0

o makt me dat wel een beetje 1 nexveus

0 makt me dat niet nerveus 2

0 kruip ik nooit in mijn 2 schulp

0 kruip $i k$ wel eens in mijn 1 schulp

o kruip ik vaak in min schulp 0

O ga ik meestal uit de weg o

o ga ik soms uit de weg 1

o ga ik niet uit de weg 2 
1. Kwadheid witen

2. Ik ben

3. Ik kxop milin exgernis

4. A.s $1 \mathrm{k}$ kwad ben

5. Als $\mathbb{1} k$ kwad ben

6. Ik kan mijn kwaadheid

7. Kwaadheid
0 durf ik wel

0 durf ilk niet zo gaed

a durf ik helemal niet

o bang voor ruzie

0 wel wat bang voor ruzle

0 niet zo bang voor ruzle

0 meestal nièt op

o vaak wèl op

o meestal wèl op

0 voel ik me meestal niet rot 2

0 voel ik me soms wêl rot 1

0 voel ik me meestal wèl rot 0

o zit ik daar vaak over te 0 piekeren

0 zit $1 \mathrm{k}$ daax soms over te 1 piekexen

0 zit ik daar vrijwel nooit 2 over te piekeren

0 goed uiten 2

0 niet zo goed uiten 1

0 eigenlijk niet witen 0

0 stapelt zich bij mijerg op 0

o stapelt zich bij mij een 1 beetje op

o stapelt zich bij mij eigen- 2 lijk niet op 
1. Als ik iemand aardig vind

2. Ik ben

3. Als lemand aardig voor milt is

4. Ik durf anderen

5. Als ik erg op iemand gesteld ben

6. Aardig zijn voox een ander

7. Als ik me aangetrokken voel tot een ander
0 kan ik dat helemaal nilet la- 0 ten merken

o kan ik dat max moellijk 1 laten merken

0 kan $1 \mathrm{k}$ dat best wel laten 2 merken

o niet bang om mijn genegen- 2 heid te uiten.

0 een beetje bang om mijn ge- 1 negenhela te uitien

o bang om mijn genegenheld te 0 uiten

- dan kan ik meestal niet 0 zeggen dat ik dat leuk wind

0 dan kan ik vaak niet zeggen 1 dat ik dat leuk vind

0 dan kan ik meestal wel zeg- 2 gen dat ik dat leuk vind

o best wel een kompliment te 2 maken

0 niet zo goed een kompliment 1 te maken

0 geen kompliment te maken 0

o dan durf ik dat ook te zeg- 2 gen

o dan durf ik dat soms niet 1 te zeggen

0 dan durf ik dat meestal niet 0 te zeggen

o vind ik niet moeilijk 2

0 vind $i k$ een beetje moeilijk 1

o vind $1 \mathrm{k}$ moejlijk

0 dan heb $\mathbb{1} k$ meestal de nei- 0 ging me af te siluiten

0 dan heb ik soms de neiging 1 me af te sluiten

0 dan hob ik nooit de reiging 2 me af te sluiten 
1. Als lemand wardering naax me uitepreekt

2. Als lemand mij een kompliment make

3. Ik vind het

4. Als lemand lets arardigs voor me doet

5. Als iemand wat aardigs tegen me zegt

6. Als Lemand me genegenheld toont
0 weet ik niet wat ik moet 0 zeggen

0 weet ik niet zo goed wat ik i moet zeggen

0 weet ik best wat ik muet 2 zeggen

0 weet jk me wel een houding 2 te geven

0 weet ik the rilet zo goed een 1 houding te geven

0 weet ik me helemal geen 0 houding te geven

0 erg moellijk te reageren als 0 lemand me genegenheid toont

a wel wat moelifjk te reageren 1 als ilemand me genegenheld toont

O niet zo moeilijk te reageren 2 als iemand me genegenheld toont

0 sta lik meestal met de mond 0 vol tanden

O sta ik soms met de mond vol 1 tanden

o sta ik bijna noolt met de 2 mond vol tanden

o dan maakt me dat erg verle- 0 gen

0 dan makkt me dat wel wat ver-1 legen

o dan maakt me dat niet ver- 2 legen

0 weet ik meestal niet wat ik 0 daarmes aan moet

0 weet ik sons nilet wat ik 1 daarmee an moet

0 weet ik meestal wel wat ik 2 daarmee aan moet 


\section{Ik weet meesta1}

2. Ik ben meestal

3. Als het erop aan komt, dan kon ik

4. Ik geef

5. Mijn mening zeggen vind ik meestal.

6. Ik ga het

7. Ik aarzel o niet hoe ik voor mijn mening o op kan komen

a niet ro goed hoe ik voor i mijn mening op kan komen.

0 best wel hoe ik voor mijn 2 mening op kan komen

0 tè bang om voox mijn mening 0 op te komen

0 wel wat bang on woor mijn 1 mening op te komen

o niet bang on woox $\mathrm{mijn}$ me- 2 ning op te komen

O bijna altijd voor mijn me- 2 ning op

a soms voor mijn mening op i

a bijna nooit voor mijn me- 0 ning op

0 meegtal tè snel toe aan wat 0 anderen willen

0 taak tè snel toe aan wat an- 1 deren willen

o bijna noolt tè snell toe aar 2 wat anderen willen

0 niet zo moeilifjk

a wel wat moellijk

0 erg moeilijk

O bijna altija uit de weg om 0 mijn mening te zeggen

o soms uit de weg om mijn me- 1 ning te zeggen

o bifna noolt uit de weg om 2 mijn mening te zeggen

o meestal te lang vooratat ik o mijn mening zeg

0 vaak te lang voordat ik miln 1 mening zeg

0 zelden te lang voordat ik 2 mijn mening zeg 
1. IK ben

2. Ik aux

3. A.s 1k tegen een ander in W1 gaan

4. Als ik tegen 1 emand inga

5. A.s ik tegen anderen in wil gaan
0 te onzeker van mezelf on te- 0 gen anderen in te gaan

0 wel wat onzeker van mezeli 1 om tegen anderen in te gaan

0 zeker genoeg van mezelf om 2 tegen anderen in te gaan

0 meestal geen 'nee' te zeggen 0

0 soms geen 'nee' te zeggen 1

0 meestal wel 'nee' te zeggen 2

0 dan kan ik best wel wit mijn 2 woorden komen

o dan kan lik maar moeilijk uit 1 mi in woorden komen

0 dan kan ik niet uit mijn 0 woorden komen

a ben ik meestal gespamen en 0 nerveus

0 ben ik soms gespannen en 1 nerveus

a ben ik zelden gespanner en 2 nerveus

a kan ik best argumenten vin- 2 den

0 kan 1 k niet zo goed argumen- 1 ten vinden

0 kan ik geen argunenten vin- 0 den 
BIJLAGE 4 : B-SKIMS, 2B, 4B, $5 B$ en $8 B$

SRIM $2 B$ : LUISTEREN

1. AIs iemand wat vertelt

0 kan ik ex meestal fijn ge- 0 dachten niet bijhouden

O kan ik soms mijn gedachten 1 ex niet bijhouden

0 kan $1 k$ mjjn gedachten ex wel 2 bijhouden

2. Als ik het ergens niet mee eens ben

O word ik erg gauw kwaad 0

0 word ik niet zo gauw kwaad 1

0 word ik helemaal niet zo 2 gauw kwaad

3. In het kort herhalen wat een ander tegen me zegt

0 vind ik erg moellijk 0

0 vind ik moeilijk 1

o vind ik niet moeilijk 2

4. IK wil

0 vaak voos mijn beurt miln 0 eigen mening kwijt

0 soms voor mijn beurt mijn 1 eigen mening $\mathrm{kwijt}$

0 bijna nooit voor mijn beurt 2 mijn eigen mening kwijt

5. Als Lemand me wat vertelt

0 dringt het meestal niet tot 0 me door wat his bedoelt

0 dringt het soms niet tot me 1 door wat hilj bedoelt

o dringt het meestal wel tot 2 me door wat hij bedoelt

6. Ik geef de ander

O meestal wel de tijd on uit 2 te praten

o valk geen tija om uit te 1 praten

0 bijna nooit de tlja om ult 0 te praten

7. Als lemand met me praat

o heb $\mathbb{1 k}$ er moeite mee on op 0 mijn gemak naar hem te luisteren

0 heb $1 k$ er een beetje moeite 1 mee om op mifn gemak naax hem te ludsteren

0 heb ik er geen moite mee om 2 op mijn gemak naar hem te I uisteren 
1. Wameer lemand $\mathrm{kwad}$ op mij is

2. Wls Lemand kwaad op me worat

3. Wanneer i emand kwaad op mij is

4. Wanneer iemand kwaad op $\mathrm{mlj}$ is

5. Wanneex i mand kwaad op mij is
0 voel ik me erg geirriteerd 0

0 voel ik me wel wat geirri- 1 teerd

0 woel ik me vrijwel niet ge- 2 irriteerd

0 zit lik meteen op de kast 0

0 zit ik soms wel gauw op de 1 kast

0 ga ik bijna noolt op de kast 2 zitten

o kan ik vaak niet goed naar 0 hem luisteren

o kan ik soms niet goed naar i hem luisteren

o kan ik meestal wèl goed naar 2 hem luisteren

0 reageer ik niet agressief 2

o reageer ik soms vrij agres- 1 sief

0 reageer ik meestal vrij ag- 0 ressief

o reageer ik meestal vinnig 0 terug

0 reageer ik soms vinnilg terug 1

o reageer ik bijna nooit vin- 2 nig terug 
1. Als ik kwaad ben

2. Als lk kwaad ben

3. Als ik kwaad ben

4. Als ik kwaad ben

5. Als $1 \mathrm{k}$ kwaad ben

6. Als ik echt kwad ben

7. Ik ben o gool l $k$ noolt met aingen 0

0 gool ik wel eens met dingen i

o gool ik vaak wet aingen 2

- Kan ik daar niet over praten 0

a kast het mij moelte daar- 1 over te praten

0 kan ik daar wel over praten 2

O hoor ik niet wat de ander o zegt

o hoor ik minder groed wat de 1 ander zegt

o hoor ik wèl wat de ander 2 zegt

o ben ik niet grof

0 ben $i k$ wel wat grof

0 ben ik exg grof

0 begin ik noolt te schelden 2 of te schreeuwen

O begin lik wel eens te schel- 1 den of te schreeuwen

0 begin ik valk te schelden of 0 te schreeuwen

o kan ik me goed beheersen 2

o kan $1 \mathrm{k}$ me niet zo goed be- 1 heexser

0 kan ik me niet meer beheer- 0 sen

O eigenlijk nooit driftig 2

0 soms wel driftig 1

0 valk driftig 0 
1. Mls ik voot mijn mening opkom

2. Als ik voox mijn mening wil opkomen

3. Als $1 \mathrm{k}$ mijn mentng wil zeggen voel ik me daarblj meestal

4. Als ik mijn mentng wil geven

5. Als $1 \mathrm{k}$ mijn menking geef voel ilk the

6. Als ik voor mezelf opkom, dar doe ik dat meestal
0 doe $1 k$ dat zelden te fel of 2 te grof

0 doe $1 k$ dat soms te fel of te 1 grof

0 doe ik dat meestal te fel of 0 te graf

0 voel ik me zelden erg gespan- 2 nen

o voel ik me vaak erg gespannen 1

o voel ik me meestal erg gespan-o nen

1 niet zenuwachtig 2

0 een beetje zenuwachtig 1

o erg zenuwachtig

o struikel ik bijna altijd over 0 mijn woorden

o struikel ik soms over mijn I woorden

o struikel ik bijna nooit over 2 mijn woorden

o bijna altijd ellenaig 0

0 soms ellendig 1

o bijna nooit ellendig 2

0 niet agressief 2

0 wel wat agressief 1

0 tè agressief 0 


\begin{tabular}{|c|c|c|c|}
\hline 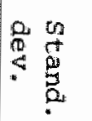 & 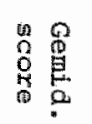 & $\Xi \vec{\omega}=50$ NaUn & $\frac{D}{E_{i}}$ \\
\hline$\ddot{~}$ & 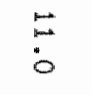 & 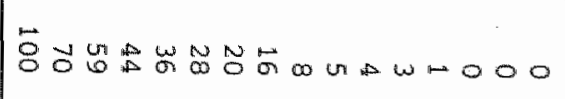 & 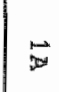 \\
\hline 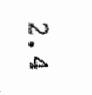 & $\begin{array}{l}\omega \\
0\end{array}$ & 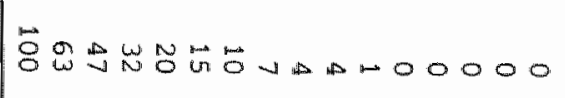 & 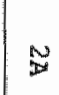 \\
\hline$\stackrel{N}{\infty}$ & $\stackrel{\vec{b}}{\Delta}$ & 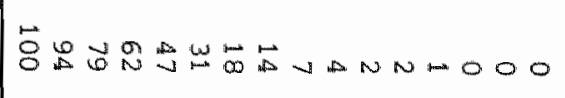 & $\tilde{\Delta}$ \\
\hline$\stackrel{\infty}{\infty}$ & in & 1 ' & $w_{j}$ \\
\hline$\stackrel{n}{\sim}$ & $i_{i n}^{\infty}$ & 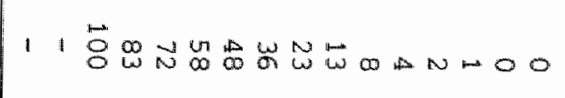 & $\$$ \\
\hline $\begin{array}{l}N \\
\omega\end{array}$ & $\stackrel{\sigma}{n}$ & | 1 | & 㽞 \\
\hline$\dot{w}_{b}^{\prime \prime}$ & in & 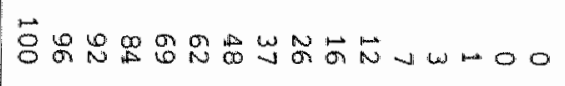 & $\stackrel{M}{D}$ \\
\hline $\begin{array}{l}\text { in } \\
0 \\
0\end{array}$ & $\stackrel{\vec{\sigma}}{i}$ & 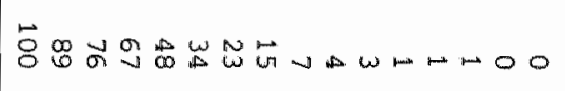 & 面 \\
\hline$\stackrel{\infty}{\infty}_{\infty}^{\infty}$ & $\underset{⿱ 宀}{\rightleftarrows}$ & 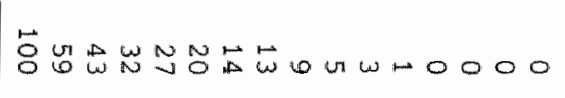 & 9 \\
\hline$\stackrel{\sim}{\sim}$ & $\dot{\sigma}_{0}^{\infty}$ & " & Dis \\
\hline$i_{i}^{\infty}$ & 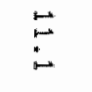 & 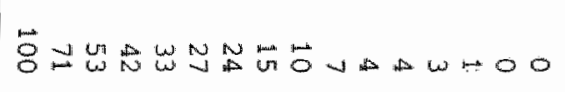 & $\mathfrak{g}$ \\
\hline$\stackrel{N}{n}$ & $\begin{array}{l}\infty \\
i \\
0\end{array}$ & 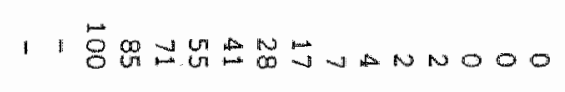 & g \\
\hline$\tilde{n}$ & $\overrightarrow{i r}$ & 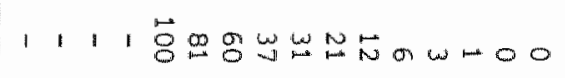 & 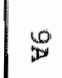 \\
\hline
\end{tabular}


1. Ik heb het qevoe 1 dat andere mensen allerlei dingen beter doen dan ik.

2. Ex zijn veel dingen die ik bij mezelf zou veranderen, als ik dat kon.

3. Ik heb het gevoel dat ik een wardevol lemand ben.

4. Ik heb zelf het gevoel dat ik veel dingen niet goed doe.

5. Ik heb niet zo'n hoge dunk van mezelf.

6. Ik ben tameldjk zeker van mezelf.

7. Soms ben ik geneiga mezelf een beetje een mislukkeling te vinden in vergelijking met anderen.

\author{
0 helemal war \\ 0 wa.ar \\ 0 een beetje waar \\ 0 eigenlijk niet waar \\ 0 niet waar \\ 0 helemal niet waar \\ o helenaal war \\ 0 waax \\ O eer beetje waar \\ 0 eigeniljk niet waar \\ 0 niet waar \\ 0 helemal nilet waar
}

0 helemaal waar

0 waar

0 een beetje waar

0 eigenlijk niet waar

0 niet wax

o helemaal niet waar

0 helemaal waar

0 waax

0 een beetje waar

0 eigeniljik niet waar

0 niet waar

0 helemaal niet waar

0 helemal war

0 waar

0 een beetje waar

o eigenlijk niet waar

0 niet war

o helemaal niet waax

o helemaal war

0 waar

0 een beetje waar

0 eigenlifk niet waar

0 niet war

0 helemal niet waar

0 helemal war

0 waar

0 een beetje waar

0 eigenli jk niet waax

0 niet waar

0 helemail niet waar 
8. Ik heb nilet veel eigenschappen on echt trots op te zijn.

9. Ik ben altija heel tevreden over de dingen die ik heb gedaan.

10. Ik wou dat ik meer zelfvertrouwen had.

11. In het algemeen ben ik heel tevreden met mezelf.

12. Ik vind dat ik evenveel goede elgenschappen heb als andexe mensen.

13. Ik schaam me wel eens voor mezelf.

14. Vaak zou ik wel anders willen zijn dan $1 k$ ben.
O hedemal war

0 war

0 een beetje war

0 eigenlfjk niet wax

D niet wax

o helemal niet war

o helemal wax

0 war

0 een beetje waax

o elgenlijk niet wax

0 miet wax

o helemaal niet waax.

0 helemal waar

0 waar

o een beetje waar

0 eigenlijk niet waar

0 niet wax

- helemal niet waar

0 helemal war

0 . waar

0 een beetye war

o eigenlijk niet wax

0 riet waax

0 helemal niet waar

0 helemal waar

o waar

O een beetje war

o eigenlijk niet war

0 niet war

0 helemal niet waar

o helemaal warix

0 waar

O een beetje waax

o eigenlijk niet waar

0 niet wax

a helemal niet waur

o helemal wax

0 waar

0 een beetje waar

O elgenlijk niet wax

o niet wax

o helemal niet waar

o helemaal war

0 wax

0 een beetje waar

o elgenlijk nilet wax

0 niet waar

o helemal niet war 
Max Beekers, geboren op 14 februari. 1947 te wistelrode, studieerde. ne 2 MULO-jaren in Paramaribo en H.B.S..-B te Vanlo, vanaf 1965 payohologie aan de Katholieke Universiteit te Nijmegen. Na the zijn afgestudeerd in 1971 makte hij ruim 3 jaar deel uit van de Werkgroep Organisatie-Ontwikkeling en Gedragsverandering (Vakgroep Organisatie-Psychologie) van de afdeling Bedxijfskunde van de Technische Hogeschool te Eindhoven. Sinds november 1974 is hif werkzaam bij de capaciteitsgroep Medische Psychologie van de Rijksuniversiteit Limburg.

Tussen 1973 en 1980 volgde hij diverse postdoctorale psychotherapieopleidingen, waaronder opleidingen psychodrama, gedragstherapie en IMPpsychotherapie, hetgeen leidde tot erkenningen als gewoon lid van de Vereniging voor Gedragstherapie in 1979 en van de Nederlandse Vereniging voor psyohotheraple in 1982.

Hij 1s coordinator van het Goldsteinproject (1977-1984), eer gezondheidszorg*ontwikkelingsproject warin medewerkers van de Rijksuniversiteit Limburg, de Toneelacademle Maastricht en de RIAGG's te Heerlen en Maastricht samenwerken en waaraan subsidies zijn verleend door het Ministerie van onderwijs (experimentele samenwerking wo-HBo) en door het Preventiefonds. Tevens cobrdineert hij het 'Deelproject Gedragsverande$x$ ing op Leertheoretische Basis', waarin naast het Goldsteinproject een aantal inhoudel1jk verwante gezondheidszorg en researchprojecten zijn ondergebracht. 